\title{
Trepostomatous Bryozoa
}

of the Hamilton Group of New York State

By RICHARD S. BOARDMAN

GEOLOGICAL SURVEY PROFESSIONAL PAPER 340

Geology, evolution, and descriptions, based on a revised method of classification

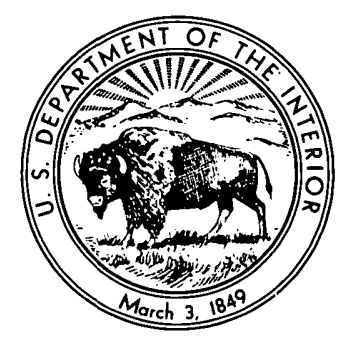




\section{UNITED STATES DEPARTMENT OF THE INTERIOR \\ FRED A. SEATON, Secretary \\ GEOLOGICAL SURVEY \\ Thomas B. Nolan, Director}

For sale by the Superintendent of Documents, U.S. Government Printing Office Washington 25, D.C. - Price $\$ 1.25$ (paper cover) 


\section{CONTENTS}

Abstract

Introduction . . .

Stratigraphy . . . . . .

Marcellus and Skaneateles formations ............

Ludlowville shale . . . . . . . . .

Moscow shale

Paleoecology .....

Bryozoa and environments.....................

Lithofacies and bryozoan faunas of the Hamilton group

Time and stratigraphic relations. . . . . . . . . . . .

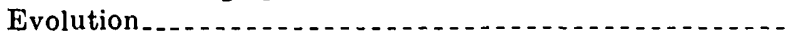

Time and space relations of lineages............

Morphologic trends of lineages....................

Comparison of Trepostomata from Hamilton and

Traverse groups. . .

Register of localities....

Glossary

Morphology and taxonomy . . . . . .

Early history of the study of the Order Trepostomata

\begin{tabular}{r|r} 
Page \\
1 \\
1 \\
3 \\
3 \\
3 \\
7 \\
8 \\
8 \\
9 \\
11 \\
12 \\
13 \\
15 \\
15 \\
18 \\
21 \\
23 \\
23
\end{tabular}

Morphology and taxonomy-Continued

Wall structure and taxonomy - -

Previous work

Wall structure and taxonomy in the Hamilton

Trepostomata.................................

Tentative groupings of genera from Hamilton

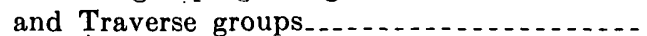

Stereotoechid wall structure...........

Leioclemid wall structure ..............

Trachytoechid wall structure .........

Leptotrypellid wall structure............

Atactotoechid wall structure

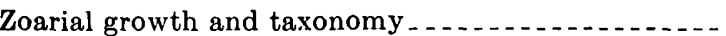

Distribution of morphologic characters within

Hamilton zoaria ........................

Zoarial variation and species criteria .........

Mode of ramose zoarial growth..................

Systematic descriptions.............

Literature cited-(-...

Index .
Page

25

25

26

29

30

30

31

32

32

33

33

35

38

40

82

85

\section{ILLUSTRATIONS}

[Plates follow index]

Plate 1. Stereotoechus, Calacanthopora, and Eridotrypella. 2. Dyoidophragma.

3, 4. Leioclema.

5. Trachytoechus.

6-14. Leptotrypella.

15. Leptotrypella, Polycylindricus.

16. Polycylindricus.

17-20. Ataclotoechus.

21, 22. Loxophragma.

FigURe 1. Outline map of New York showing area studied..............................

2. Members of the Ludlowville and Moscow formations arranged relative to their inferred time and geographic position......

3. Stratigraphic distribution of the trepostomatous Bryozoa of the Hamilton group of New York

4. Time-space diagram of the genus Leptotrypella in the Hamilton group of New York -

5. Time-space diagram of the genus Atactotoechus in the Hamilton group of New York..

6. Map showing outcrop of Hamilton group, and collecting localities................

7. Diagrams illustrating standard measure-

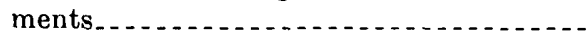

8. Diagrammatic tangential and longitudinal sections of a zooecium illustrating the laminated structure of the skeleton........

9. Diagram of stereotoechid wall structure...

10. Diagram of leioclemid wall structure......

11. Diagram of trachytoechid wall structure... -

12. Diagram of leptotrypellid wall structure ... -

13. Diagram of atactotoechid wall structure... -

14. Graph of measurements along length of zoarium of holotype of Leptotrypella asterica. -
Figure 15. Graph of measurements along length of zoarium of Leptotrypella multitecta.......-

16. Peripheral scatter diagram of Atactotoechus cartus cartus of number of diaphragms against width of ephebic zone..........

17. Peripheral scatter diagram of Atactotoechus cartus cartus of number of diaphragms against axial ratio.
Page

2
Page

23. Chart of possible phylogenetic relationships of some of the species of the genus Leptotry-

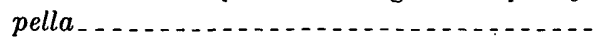

24. Peripheral scatter diagram of the Leptotrypella mesostena-multitecta lineage......-

25. Possible phylogenetic relationships of the New York species of the genus Atacto-

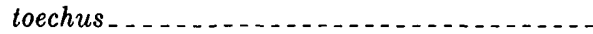

26. Peripheral scatter diagram of some of the

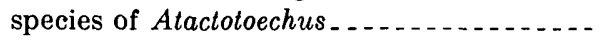

27. Peripheral scatter diagram cf the New York

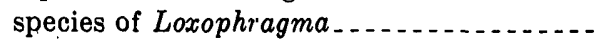

\section{,} "7 " 


\title{
TREPOSTOMATOUS BRYOZOA OF THE HAMILTON GROUP OF NEW YORK STATE
}

\author{
By Richard S. BoARdman ${ }^{1}$
}

\begin{abstract}
The trepostomatous Bryozoa known from the Middle Devonian Hamilton group of New York represent 26 species and two subspecies: belonging to 10 genera and 1 subgenus. Two genern, Polycylindricus and Loxophragma; the subgenus, Leptotrypella (Pycnobasis); and 19 species and the 2 subspecies are new.

In the area of study from Lake Erie to Owasco Lake, Trepostomata are known only from the Ludlowville and Moscow formations. Some species have a restricted stratigraphic distribution. In the Ludlowville shale, four species are restricted to the Centerfield limestone member, 1 subspecies to the Ledyard member of Cooper (1930), three species to the Wanakah member as used by Buehler and Tesmer (in press), and 1 species is restricted to the King Ferry shale member of Cooper (1930). In the Moscow shale, 1 species and 1 subspecies are restricted to the Kashong member of Cooper (1930) and 4 species are restricated to the uppermost Windom member.
\end{abstract}

The Hamilton rocks of western and central New York consist largely of calcareous mudstone, shale, and limestone. Five rock types are represented, and these are closely correlated with the distribution of faunas. Trepostomata are abundant in the calcareous mudstone facies, sparse in the siltstone and coral-bearing limestone, and were not found in the dark shale and sandstone. Application of Stach's findings on Recent Bryozoa to the Hamilton species suggests that growth habit was controlled largely by the amount of agitation in the water, "unstable" species developing ramose colonies in quiet water and incrusting colonies in agitated water. The predominantly incrusting colonies and bioclastic matrix in the coral-bearing limestone facies suggest agitated waters; the predominantly ramose colonies preserved as complete zoaria in the calcareous mudstone facies suggest quieter waters.

The defined members of the Ludlowville and Moscow formations are considered, on the basis of the distribution of the bryozoan species, , to be essentially coeval, and phylogenetic linenges are inferred in three genera. A general increase in size of zoaria is demonstrated in the lineages of the three genera.

The present study indicates that amalgamate and intergrate wall structures in tangential sections are not reliable subordinal criteria, primarily because occurrence of amalgamate or integrate walls is not always constant within a species or genus. Longitudinal sections demonstrate that either an amalgamate or an integrate appearance can be produced by variations in either one of two wall structures now tentatively considered to be fundamentally different and taxonomically

\footnotetext{
${ }^{1}$ Now with the Smithsonfan Institution, Washington, D.C.
}

important. Hamilton genera do not fit into the present family classification, partly due to the lack of recognizable "primary" and "secondary" parts of zooecial walls. A tentative group ing of the Middle Devonian genera is based on the configuration of the laminae in the zooecial walls as seen in both longitudinal and tangential sections. ' One tentative subordinal group includes genera displaying stereotoechid, leioclemid, trachytoechid, .and leptotrypellid wall structures, all defined in this paper. The other.group includes the genera showing atactotoechid wall structure, also defined. The wall structure for each of the Hamilton genera is described in detail and previously described species are reassigned where necessary.

The nearly complete ramose zoaria collected in the Hamilton group furnished material for study of morphologic variation within a colony. The amount of variation indicates that "species" could be and probably have been .differentiated on characters commonly. occurring in a single zoarium. Intrazoarial variation of characters falls into two natural groups: that controlled by growth stages (ontogeny), and that largely independent of ontogeny. To evaluate and make usable characters affected by ontogeny, growth stages are arbitrarily defined by numbers of diaphragms in the zooecia. Measurements of the other ontogenetic characters, primarily width of ephebic zone and axial ratio, are recorded for each of these growth stages and presented either in scatter diagrams or tables. After study of complete trepostomatous zoaria of the Hamilton group, it is evident that if a reasonable number of disassociated fragments of trepostomes from the average collection is studied, an adequate approximation of growth stages can be obtained and more realistic species concepts established.

The nearly complete ramose zoaria also provide information on the nature of growth in branching colonies. A ! proposed growth hypothesis is based on cyclic growth and resorption. Thick zooecial walls were periodically formed around the ends of the branches, as shown by their presence in 80 percent of the sectioned growing tips. The thick zooecial walls were partly resorbed in the growing tip region and active thinwalled growth followed, extending the neanic zones and branch lengths distally. The formation of new thick-walled zones around the tips completed the cycle. Proximal to the growing tips, the zooecia assumed permanent positions opening along the sides of the branches. Here growth was relatively constant with no sign of resorption and progressively older growth stages occur toward the bases of zoaria.

\section{INTRODUCTION}

The Hamilton group of New York State has been considered one of the classic Middle Devonian sections of the world since the early work of James Hall 
with the New York Geological Survey. The Hamilton fauna is noted for its abundance, diversity, and excellent preservation. The bryozoan element of the fauna includes representatives of all four Paleozoic orders and is especially distinguished by the common occurrence of essentially complete zoaria.

This paper deals with one of the four Paleozoic orders of the Bryozoa, the Trepostomata. The purpose of the study is to review and re-evaluate the morphology and its bearing on taxonomy and to describe the fauna and investigate its possible stratigraphic value.

The fieldwork was done during the summer of 1952 and 1953. The material studied includes collections made available by the U.S. National Museum in addition to those collected by the author for the U.S. Geological Survey. Within the Hamilton group, the Trepostomata were found only in the Ludlowville and Moscow formations of the Tioughnioga stage of Cooper and others (1942) and were geographically limited to the region between Lake Erie and Cayuga Lake, with the exception of a few rare occurrences farther east in New York (fig. 1).

Previous work on the Bryozoa of New York State was done almost entirely by James Hall and his colleagues. Hall did not use thin sections in his work and most of his species will not be recognizable until the types are sectioned. Few of the species Hall described are of the Trepostomata, as this order shows

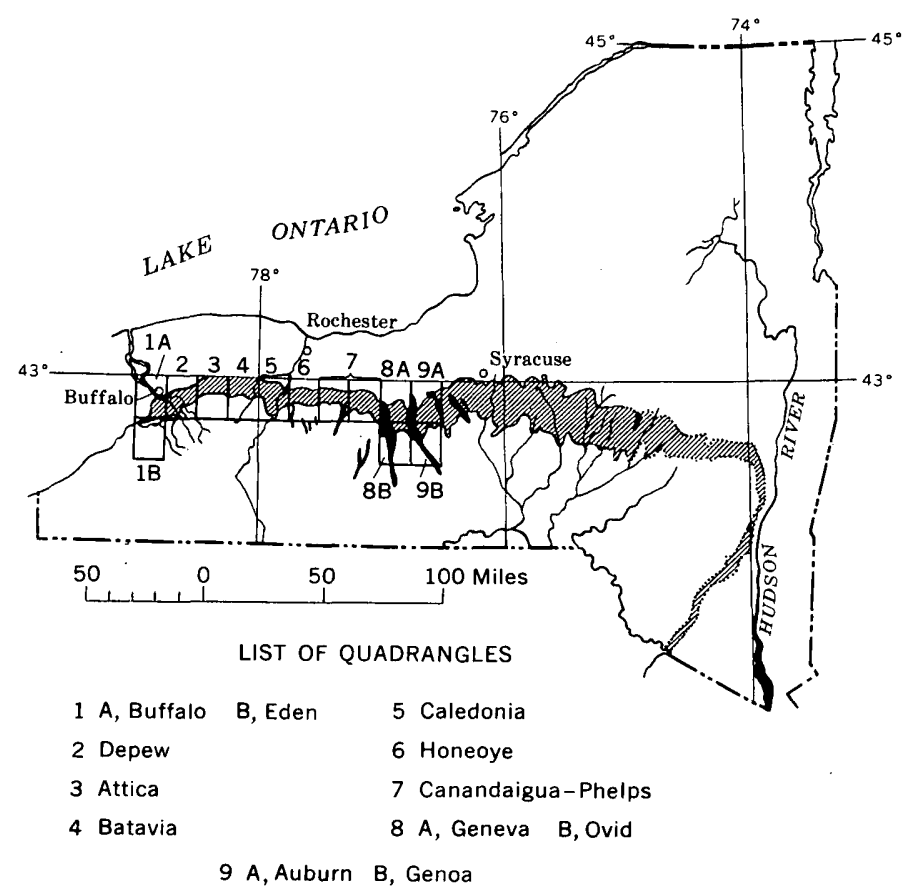

Figure 1.-Map of New York State showing the area of the outcropping belt of the Hamilton group and outlines of the Geological Survey quadrangle maps covering the area studied. little differentiation externally. Most of Hall's work is concerned with the Cryptostomata and Cyclostomata and was published between 1873 and 1891. His most comprehensive work on the Bryozoa was published in 1887 (Hall and Simpson).

A few other trepostomatous Bryozoa from New York are described in papers dealing largely with other areas or with general faunal studies. Ulrich (1890, p. 416, pl. 45, figs. 5-5d) described Dekayia devonica, some of the cotypes coming from the Eighteen Mile Creek section, Erie County, New York (present report, p. 67). Grabau (1899, p. 137, fig. 22) described Monotrypa amplectens from the Averys Creek section, Erie County, New York, in a general faunal study of the Hamilton group of the Eighteen Mile Creek section (present report, p. 60). Ulrich and Bassler (1904, p. 39, pl. 11, figs. 10-12) described Leioclema monroei from a locality near Bethany, N.Y. (present report, p. 45).

The known work on the Trepostomata of the Hamilton of New York is covered in this short summary. The large proportion of new species described in this paper reflects the lack of work done on the order.

The only major study of Trepostomata of Hamilton age outside of New York State is that of Duncan (1939) on the fauna of the Traverse group of Michigan. Eleven new genera were erected, 6 of which occur in New York. Other authors described one to several species of Traverse Trepostomata without attempting a complete study (Winchell, 1866; Rominger, 1866; Ulrich, 1890; and Bassler, 1911b). Scattered species are also described from strata of Hamilton age in Ontario by Nicholson (1874a, 1874b) and Fritz (1930). Bassler (1911b) described several species from the Devonian of Wisconsin, and Ulrich and Bassler (1913b) described a single species from the Romney shale of Maryland. Single species were described from Hamilton equivalents in Iowa (White, 1876) and Ohio (Stewart, 1927).

This work was done under the guidance of Helen Duncan, of the U.S. Geological Survey. U. S. National Museum specimens included in the study were collected by G. A. Cooper, A. R. Loeblich, Jr., and I. G. Reimann. Collecting localities were suggested by the late R. R. Hibbard, of Buffalo, N.Y., J. W. Wells, G. A. Cooper, and I. G. Reimann. James Hall's type specimens were generously made available for sectioning and study by D. W. Fisher, C. F. Kilfoyle, and N. D. Newell. Type thin sections of Traverse species were loaned to the writer by G. M. Ehlers. Many helpful suggestions were made by G. A. Cooper, W. A. Oliver, Jr., F. H. T. Rhodes, and H. R. Wanless. 


\section{STRATIGRAPHY}

The Hamilton group of New York is part of the standard North American Devonian column and is correlated with the Eifelian and most of the Givetian of Europe (Cooper, and others, 1942). With the exception of the Tichenor limestone member and the Wanakah shale member as used by Buehler and Tesmer, in press of the Ludlowville shale, the stratigraphic units used in the present paper are as defined in a definitive paper on the detailed stratigraphy of the Hamilton group by G. A. Cooper (1930).

Trepostomatous Bryozoa occur most commonly in the Hamilton outcrops between Lake Erie on the west and Cayuga Lake in central New York State (figs. 1,6). The outcrop area of the Hamilton between these lakes is a 10-mile belt extending eastward from Lake Erie. The rocks are nearly flat lying; the prevailing dip is to the southeast about 34 feet per mile (Cooper, 1930 , p. 119). The main stratigraphic problems are concerned with facies changes and rather obscure lithologic differences at the boundaries between some members. Fortunately, thin distinctive faunal zones appear to be continuous over large areas and afford a measure of stratigraphic control.

The Hamilton group is primarily a clastic sequence consisting of calcareous mudstone, shale, and siltstone. A few thin, persistent limestone units, such as the Centerfield and Tichenor limestone members, are interbedded with the shales. The group shows a general increase in thickness eastward, and is 285 feet thick at Lake Erie and 680 feet thick at Cayuga Lake (Cooper, 1930, p. 121). As the clastic beds thicken eastward, the shale and mudstone that predominate in the Lake Erie region gradually change to siltstone in the Finger Lakes region. East of Cayuga Lake sandy beds are predominant.

\section{MARCELLUS AND SKANEATELES FORMATIONS}

No trepostomatous Bryozoa were found in the two lower formations of the Hamilton in the area studied. The Marcellus shale is generally a dark gray to black, bituminous, fissile shale that contains a sparse fauna.

The Skaneateles shale has the thin Stafford limestone member at the base. The Stafford is 15 feet thick at Lake Erie (Cooper, 1930, p. 216) and thins eastward, finally losing its identity east of Seneca Lake, where its position in the section is occupied by the Mottville member of Smith, 1916. At Lancaster, the Stafford contains small brachiopods, gastropods, trilobites, and fistuliporoid and fenestellid bryozoans. The superjacent Levanna shale of Cooper (1930) is a fissile to platy dark shale containing a sparse fauna very similar to that of the Marcellus shale (Cooper, 1930, p. 217).

\section{LUDLOWVILLE SHALE}

Trepostomatous Bryozoa first appear in the Centerfield limestone member at the base of the Ludlowville shale (fig. 2). They are very rare in the overlying Ledyard member of Cooper (1930) and become common to abundant in the poorly bedded, light-gray, calcareous shale and mudstone members in the upper part of the formation.

Centerfield limestone member.-The Centerfield limestone member is predominantly limestone and occurs at the base of the Ludlowville shale. The member contains the lowest occurrence of trepostomatous Bryozoa known in the Hamilton group. The type locality is on Schaffer Creek, 1 mile north of Centerfield in the Canandaigua quadrangle. Here the Centerfield member is about 20 feet thick and is comprised of alternate thin limestones and shales. Both the limestones and shales are abundantly fossiliferous, typically containing large colonial and solitary corals and massive and encrusting fistuliporoid Bryozoa. Surrounding the larger more massive fossils is a matrix of comminuted fossil debris. Westward the member thins and is less shaly. At Blossom in the Depew quadrangle the Centerfield is only $41 / 2$ feet thick; and west of this locality, typical Centerfield lithology is not known.

The Centerfield thickens east of the type section, and shale and mudstone become predominant. At Seneca Lake the lower 12 to 15 feet of the Centerfield is homogeneous mudstone containing a few thin, shaly limestone layers. The mudstone is sparsely fossiliferous; the limestones contain the typical coral assemblage. The matrix of the limestone between larger corals is a fine calcareous mud, not the broken fossil debris that is common farther west. The upper 15 feet of the Centerfield at Seneca Lake is a soft, medium- or poorly bedded shale; 1 - to 2-inch layers of more resistant fossil debris are common in this interval, and large nodules of limestone are scattered throughout. The fauna consists largely of brachiopods, trepostomatous bryozoans and a few small specimens of Pleurodictyum. The typical Centerfield coral fauna is not developed in this upper zone.

At Moonshine Falls on Cayuga Lake, the upper 3 to 4 feet of the Centerfield is well exposed. This uppermost rock is composed of shaly limestone and limy shale. Large colonies of tabulate corals occur sparsely, and brachiopods, trepostomatous and fistuliporoid bryozoans, horn corals, and trilobites are common. 


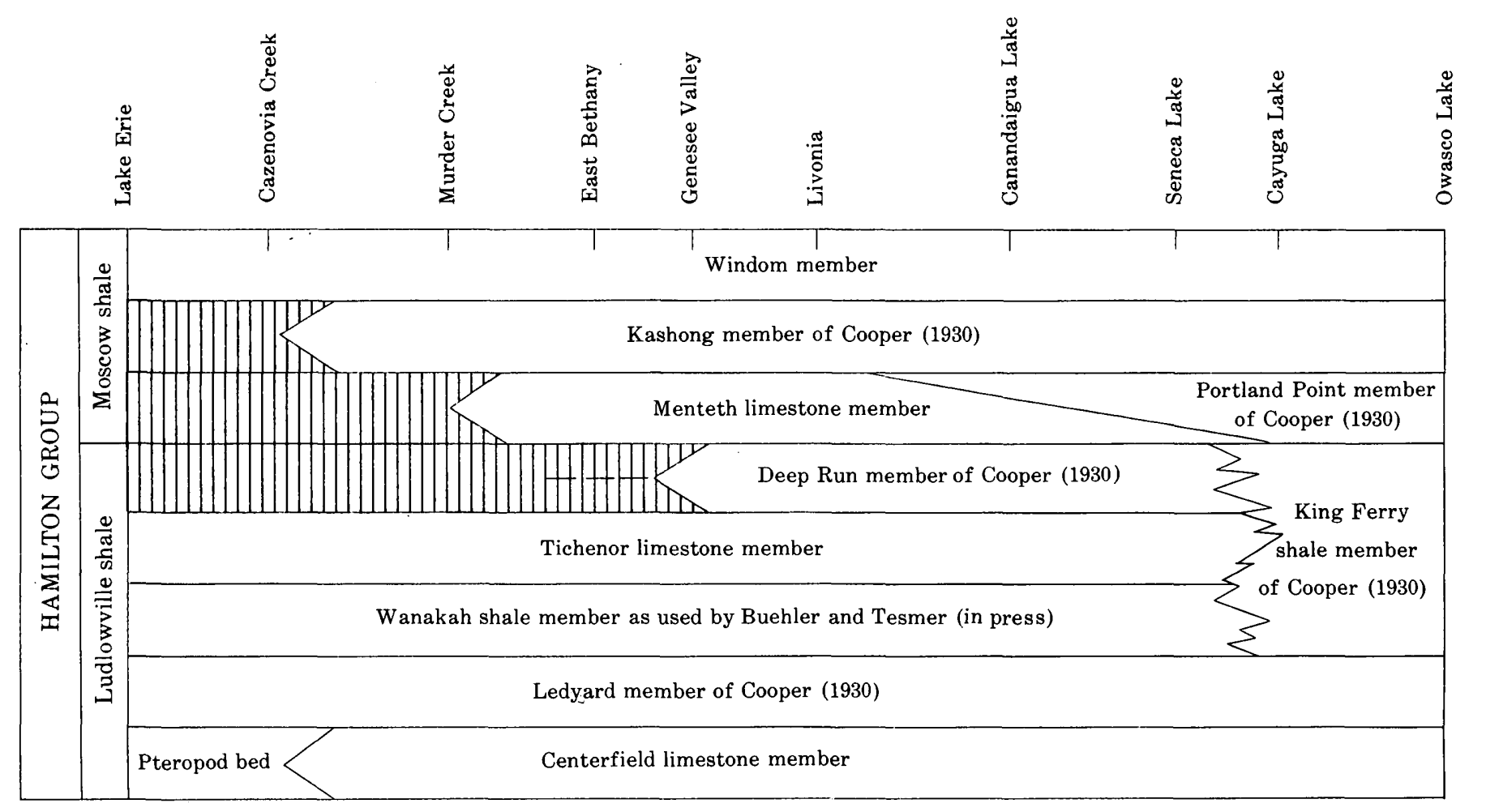

Figure 2.-The members of the Ludlowville andi Moscow formations are arranged relative to their inferred time and geographic position (modlfied from Cooper and others, 1942); time lines are horizontal, geographle position from west to east along the outcrop belt of the Hamilton group is indicated by the place names at top of diagram.

The Centerfield limestone member has a distinctive trepostome fauna. In general, zoaria of the Centerfield species occur in the interbedded shales and become more abundant eastward as the member becomes more shaly. Thus, the trepostomatous bryozoan element in the Centerfield faunule is most useful stratigraphically in the Finger Lakes region. Four species (fig. 3) are presently known only from the Centerfield member. Three of these, Trachytoechus variacellus, Leptotrypella mesostena mesostena, and Loxophragma leptum are fairly widespread geographically. Stereotoechus cf. S. typicus is known from one specimen in the Centerfield member in the Batavia quadrangle and is not important stratigraphically. T. variacellus is common in the upper few feet of the Centerfield member in the Finger Lakes region. In addition, Polycylindricus clausus is widespread geographically in the Centerfield member and occurs with $T$. variacellus in large numbers in the upper few feet of the Centerfield at Cayuga Lake; $P$. clausus also is very rare at a single Ledyard locality and there are a few specimens in the Windom member at the top of the Hamilton. Both $T$. variacellus (see p. 49) and the genus Polycylindricus (p. 67) have distinctive exter- nal appearances, and if found together in abundance are indicative of the Centerfield limestone member in New York.

Ledyard member of Cooper (1930).-The Ledyard member is a shale that overlies the Centerfield limestone member. The type section is on Paines Creek, Ledyard township, Cayuga Lake. The Ledyard is continuous from its type locality to Lake Erie, and, except for local lenticular thickening, thins westward (see Sutton, 1951, p. 366). At Cayuga Lake the thickness ranges from 60 to 100 feet (Cooper, 1930, p. 224) and at Lake Erie the member is 30 feet thick. At the type section the Ledyard is a dark fissile shale with a few thin beds of medium to light gray, poorly bedded shale at irregular intervals. The fauna is sparse and generally similar to that of the Marcellus shale (Cooper, 1930, p. 224). In the White Creek area of the Batavia quadrangle the lower 15 feet of the Ledyard member is a light gray, poorly bedded shale that contains an abundance of chonetid brachiopods and the only specimens of Trepostomata found in the member. Above the 15 foot basal unit, the Ledyard is thin-bedded to fissile and fossils are rare. Because 


\begin{tabular}{|c|c|c|c|c|c|c|c|c|c|c|}
\hline \multirow[t]{3}{*}{ FORMATION } & \multicolumn{3}{|c|}{ Moscow shale } & \multicolumn{7}{|c|}{ Ludlowville shale } \\
\hline & \multirow[t]{2}{*}{ 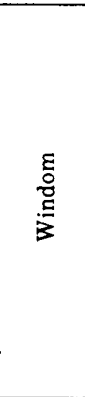 } & \multirow[t]{2}{*}{ 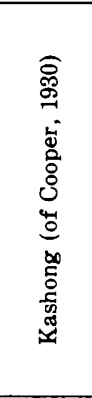 } & \multirow{2}{*}{ 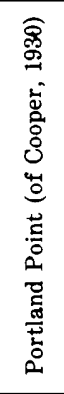 } & \multirow{2}{*}{ 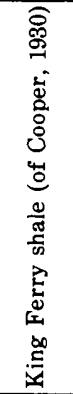 } & \multirow{2}{*}{ Nầ } & \multicolumn{3}{|c|}{ 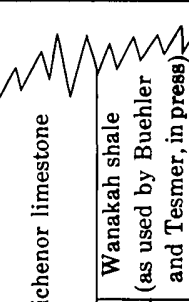 } & \multirow[t]{2}{*}{ 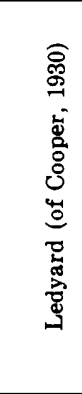 } & \multirow[t]{2}{*}{ 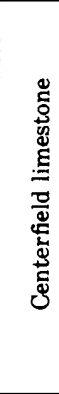 } \\
\hline & & & & & & & $\begin{array}{l}\text { 旁 } \\
\text { 号 }\end{array}$ & 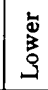 & & \\
\hline Stereotoechus cf. S. typicus Duncan & & & & & & & & & & 1 \\
\hline Trachytoechus variacellus (Hail) & & & & & & & & & & 3 \\
\hline Leptotrypella mesostena mesostena Boardman, n. subsp. & & & & & & & & & & 3 \\
\hline Loxophragma leptum Boardman, $\mathrm{n} . \mathrm{sp}$. & & & & & & & & & & 2 \\
\hline Leioclema confertiporum (Hall) & & & & & & & & ?. & & 2 \\
\hline Polycylindricus clausus Boardman, n. sp. & 2 & & & & & & & & 1 & 4 \\
\hline Atactotoechus acritus Boardman, n. sp. & 1 & & & & & & & 1 & 2.1 & 2 \\
\hline Dyoidophragma polymorphum Boardman, n. sp. & 1 & 3. & 1 & 1. & & & & 3 & & 1 \\
\hline Leptotrypella mesostena provecta Boardman, n. subsp. & & & & & & & & & 1 & \\
\hline Loxophragma lechrium Boardman, n. sp. & & 2 & & 3. & & 1 & & 4. & 1. & \\
\hline Calacanthopora? senticosa Boardman, n. sp. & & & & & & & & 3 & & \\
\hline Leptotrypella amplectens (Grabau) & & & & & & & $\approx$ & 3. & & \\
\hline Polycylindricus asphinctus Boardman, n. sp. & & & & & & & T. & 2. & & \\
\hline Leptotrypella pachyphragma Boardman, n. sp. & & & & & & 1 & & 1 & & \\
\hline multitecta Boardman, n. sp. & & & & 2 & & & & 4. & & \\
\hline Atactotoechus cartus cartus Boardman, n. subsp. & & & 4 & & & & & 1 & & \\
\hline Leioclema decipiens (Hall) & & 1 & & 1 & & & & 2 & & \\
\hline Leptotrypella asterica Boardman, n. sp. & & 4 & 1. & 1 & & & & 1 & & \\
\hline amphelicta Boardman, n. sp. & & 1 & & & & 1 & & 2 & & \\
\hline magniporta Boardman, n. sp. & 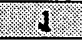 & & & & & 1 & & 2 & & \\
\hline tuberata Boardman, n. sp. & & & & 1 . & 1. & & & & . & \\
\hline Atactotoechus parallelus Boardman, n. sp. & & & & 1. & & & & & & \\
\hline Leptotrypella polita Boardman, n. sp. & & 1 & & & & & & & & \\
\hline Atactotoechus cartus pilatus Boardman, n. subsp. & & 3 & & & & & & & & \\
\hline Leioclema elasmaticum Boardman, n. sp. & 2 & & & & & & & & & \\
\hline Leptotrypella furcata (Hall) & 4 & & & & & & & & & \\
\hline Atactotoechus hystricosus Boardman, n. sp. & 2 & & & & & & & & & \\
\hline fruticosus (Hall) & 4 & & & & & & & & & \\
\hline
\end{tabular}

Fiouns 3.-Stratigraphic distribution of the trepostomatous Bryozon of the Hamilton group of New York. Numbers from 1 to 4 indicate increasing relative abundance of zoaria of a specles in localities where that species occurs. The King Ferry shale member of Cooper (1930) is an eastern silty factes considered to be laterally equivalent to the Wanakah shale member as used by Buehler and Tesmer (in press), Tichenor limestone member and Deep Run members of Cooper (1930).

of their scarcity, trepostomatous Bryozoa have little stratigraphic value in the Ledyard member. However, the few specimens from the White Creek locality are important in tracing the phylogenies of several genera (p. 14).

Wanakah shale member as used by Buehler and Tesmer (in press).-The Wanakah shale member overlies the Ledyard member of Cooper (1930) and is generally a fossiliferous shale and mudstone. The type locality of the Wanakah shale member is in the Wanakah and Lakewood Beach cliffs, along Lake Erie. As used here and by Buehler and Tesmer (in press), the Wanakah shale member includes the shale and mud- stone sequence beginning with the Strophalosia and Pleurodictyum beds and terminating at the lowest limestone layer of the overlying Tichenor limestone member.

The Wanakah shows little regional change in thickness (see Sutton, 1951, p. 367) and can be traced as far east as Seneca Lake. East of Seneca Lake the member becomes more silty and sandy and loses its identity, becoming part of the King Ferry shale member of Cooper (1930). Trepostomatous Bryozoa are generally abundant in the Wanakah and are concentrated in two zones: the Pleurodictyum zone at or near the base of the member, and the Stropheodonta de- 
missa zone in the upper few feet of the Wanakah shale member.

The Pleurodictyum zone is well exposed in the bed of Cazenovia Creek (locality 9, Depew quadrangle) where the zone is essentially a series of lenses of highly calcareous fossil material. The lenses are generally less than 1 foot thick and are separated by 3 to 4 inches of less fossiliferous shale and mudstone. A few ramose zoaria were found with intact branches extending from the lenses into the surrounding shale. The fauna is characterized by the small tabulate coral Pleurodictyum, abundant small horn corals, brachiopods, and branching trepostomes, all well preserved. These relatively large fossils are embedded in a matrix of mudstone and comminuted fossils consisting mainly of broken crinoid columnals. In the Genesee Valley to the east, the Pleurodictyum zone is largely shale and mudstone with only a few thin lenses of fossiliferous material. Still further east of the Pleurodictyum zone is less conspicuous though it can be found in the King Ferry shale member in the Cayuga Lake area.

The strata of the Wanakah member between the Pleurodictyum zone and the Stropheodonta demissa zone are generally homogeneous poorly bedded shale and mudstone. These beds are poorly to moderately fossiliferous; a few half-inch layers of broken fossil material occur at random.

The Stropheodonta demissa zone, which lies near the top of the Wanakah shale member west of the Finger Lakes area, contains most of the ramose trepostomes that are common in the Pleurodictyum zone. The lithology is generally similar to that of the Pleurodictyum zone. In the Canandaigua quadrangle, the upper 15 feet of the Wanakah has thin, limy fossiliferous beds and lenses that average 1 to 2 inches in thickness. These limy beds are separated by unfossiliferous shale and mudstone beds 3 inches to 2 feet thick. In the Seneca Lake region farther east, the thin fossiliferous zones containing trepostomatous Bryozoa occur throughout the Wanakah member.

Three species are restricted to the Wanakah shale member. Of these, Leptotrypella amplectens (Grabau) is easily recognized in the field by its constant association with the brachiopod Spinocyrtia granulosa (Conrad) and Aulocystis tubaeformis (Goldfuss) an auloporoid coral (p. 60). The species is fairly common where found, but appears restricted geographically in New York to the Buffalo and Depew quadrangles, the two extreme western quadrangles of the outcropping rocks of the Hamilton group. Polycylindricus asphinctus is less common but is found from Lake Erie to the Genesee Valley area. Calacanthopora? senticosa is rare and occurs at only one locality, in the Buffalo quadrangle.

Leptotrypella multitecta (p. 57) is the most characteristic bryozoan species of the Wanakah shale member, occurring abundantly in both the Pleurodictyum and Stropheodonta demissa zones from Lake Erie as far east as the Batavia quadrangle and appearing again in the Cayuga Lake region in the King Ferry shale member, which is partly equivalent to the Wanakah member. Loxophragma lechrium is abundant in the Wanakah and King Ferry members from Lake Erie to the Cayuga Lake region. However, the species also occurs in the Kashong member (of Cooper, 1930) of the Moscow shale in the Genesee Valley and at Seneca Lake.

Tichenor limestone member.-The Tichenor limestone member as used in this paper is bioclastic limestone interbedded with minor amounts of shale. The fauna of the limestones is characterized by massive colonial corals, encrusting fistuliporoid bryozoans, extremely large crinoid columnals, and many brachiopods. The fauna of massive colonies and bioclastic matrix probably indicates an ecological similarity with the Centerfield limestone member. The few trepostomes found in the Tichenor member occurred in the thin shale beds.

Cooper (1930, p. 226) drew the Wanakah-Tichenor boundary at the first appearance of the typical Tichenor fauna in the shale underlying the limestone of the Tichenor. The fauna in the shale beds underlying the limestones appears to change progressively upward from a calcareous mudstone fauna (see p. 10) rich in branching trepostomes to the coralline fauna that excludes the trepostomes. The species of trepostomes that occur in the transitional shale, which is here included in the Wanakah shale member as used by Buehler and Tesmer (in press), also occur in the Pleurodictyum zone near the base of the Wanakah.

Deep Run member of Cooper (1930).-This member overlies the Tichenor limestone member between the Genesee Valley area and Seneca Lake, where it is the highest member in the Ludlowville shale. Generally it is a hard brittle calcareous medium- to poorly bedded shale. A single zoarium of Leptotrypella tuberata was found in the Deep Run member at Canandaigua Lake.

King Ferry shale member of Cooper (1930).-The King Ferry shale member is generally a siltstone and is considered the lateral equivalent of the Wanakah shale, Tichenor limestone, and Deep Run members (Cooper, 1930, p. 228), which are distinguished west of the Cayuga Lake region (fig. 2). The type locality is at Clearview, King Ferry, Cayuga Lake. There the 
member is a homogeneous poorly bedded siltstone or silty mudstone with a sparse fauna distributed fairly evenly throughout the member. A Portland Point on Cayuga Lake, however, the member contains abundantly fossiliferous beds averaging about 1 inch in thickness and separated by 2 to 4 inches of nearly barren shale. Partly complete branching trepostome zoaria were found lying horizontally within the fossiliferous layers and 1 zoarium was standing vertically between 2 fossiliferous layers. However, most of the fossiles in the thin zones are fragmental.

Leptotrypella multitecta is fairly common 30 or 40 feet from the top of the King Ferry shale member that measures just over 130 feet in total thickness in the Cayuga Lake region. If it could be assumed that L. multitecta was restricted to the Wanakah shale member or time-rock equivalents of that member, the lower three-fourths of the King Ferry member could be correlated with the Wanakah. Unfortunately, other species of Trepostomata occurring in the 2 collections are of little stratigraphic value in the King Ferry or Wanakah members and there is no evidence that $L$. multitecta could not have continued in post-Wanakah sediments in the Cayuga Lake region. Atactotoechus parallelus is known from just 1 zoarium found in the King Ferry member so the species is too rare to have stratigraphic significance. Leptotrypella tuberata is known from a zoarium in the Deep Run member and another in the King Ferry member, so that species also has little stratigraphic value. Besides these 2 rare species, the remaining 5 species found in the King Ferry member also occur in the Wanakah member and 3 of them are found in the Moscow shale above.

\section{MOSCOW SHALE}

The Moscow shale is characterized by calcareous shales and mudstones containing abundant and well preserved fossils. The dominant Trepostomata are large ramose species that were apparently short lived and have considerable stratigraphic and time significance.

Portland Point member of Cooper (1930).-The Portland Point member is essentially an impure limestone interbedded with varying amounts of mudstone and shale. The type section of the member is in the creek at Portland Point on Cayuga Lake. The member here is $81 / 2$ feet thick (Cooper, 1930, p. 229) and has a basal 1 foot crinoidal limestone followed by alternations of fossiliferous shale and impure limestone in discontinuous beds and lenses.

The basal limestone of the Portland Point member extends westward and is considered to be equivalent to the Menteth limestone member (Cooper, 1930, p.
230). The Menteth limestone member can be traced westward beyond the Genesee Valley and no trepostomes were found in it.

The Portland Point member continues westward to the Canandaigua Lake region where the interval above the basal limestone is a homogeneous mudstone 15 feet thick followed by a 3 -foot bed of 1 - to 3 -inch clastic limestone layers interbedded with thin shale partings.

Only three species were collected from the Portland Point member. Atactotoechus cartus cartus occurs abundantly, but only at one locality on Canadaigua Lake. Dyoidophragma polymorphum and Leptotrypella asterica are very rare in the Portland Point and are not important stratigraphically in that member.

Kashong member of Cooper (1930).--The Kashong member is composed of shale, mudstone, and limestone and extends from the Cayuga Lake region westward into the Depew quadrangle. The type locality is on Kashong Creek where the unit is 24 feet thick (Cooper, 1930, p. 231). The lower 15 feet of the Kashong here consists of hard, limy fossiliferous layers averaging 1 inch in thickness alternating with relatively unfossiliferous mudstone and shale beds ranging from 3 inches to more than 1 foot in thickness. Overlying the 15-foot basal zone is a zone of large calcareous pyrite-bearing concretions in a shale matrix. Fossils are rare in this zone. The concretion zone is overlain by resistant hard homogeneous, impure limestone beds containing few fossils, interbedded with fossiliferous shale and mudstone averaging 1 foot in thickness. The limestone beds range in thickness from 2 inches to more than 1 foot. The fossils in the shale and mudstone beds are concentrated in thin layers. West of the Genesee Valley the Kashong loses most of the thin fossiliferous layers and consists of homogeneous mudstone yielding few fossils.

Leptotrypella asterica is the most abundant and characteristic species in the Kashong member. The species is very rare below this member although its range extends down to the Wanakah shale member. The other stratigraphically important species is Atactotoechus cartus pilatus that is known only from the Kashong and is common and geographically widespread. Leptotrypella polita is known from a single zoarium at the type locality of the member. Two other species that are abundant in the Kashong, Dyoidophragma polymorphum and Loxophragma lechrium, are long ranging and common in members below the Kashong member.

Windom member.-The Windom is the shale at the top of the Hamilton group and its type section is on Smokes Creek at Windom, in the Buffalo quadrangle. The member increases in thickness eastward from 50 
feet at the type locality to 120 feet at Cayuga Lake (Cooper, 1930, p. 232). In the Depew quadrangle the Windom is a light-gray mudstone or shale containing few fossils and few thin limy zones. In the Genesee Valley the Windom is abundantly fossiliferous; the fossils are concentrated in 1- to 3 -inch layers that are interbedded with relatively unfossiliferous mudstones averaging 1 foot in thickness. Some thin layers contain comminuted fossil debris, others contain forms showing little disturbance or mechanical breaking. This same general lithology persists eastward to Cayuga Lake as the member thickens. Large branching trepostomes, fistuliporoids, and favositid corals are abundant at various levels in the upper half of the Windom in the Cayuga Lake region.

The Windom has a distinctive trepostome fauna with four species (fig. 3) restricted to the member. Of these, Leptotrypella furcata and Atactotoechus fruticosus occur abundantly between the Genesee Valley and Cayuga Lake. Leioclema elasmaticum is fairly common from the Genesee Valley to Seneca Lake and Atactotoechus hystricosus is known only from the Windom member at Owasco Lake. The remaining species known in the Windom are not common in the member and are also found in other members in the Hamilton group.

\section{PALEOECOLOGY}

\section{BRYOZOA AND ENVIRONMENTS}

Bryozoa are considered to be potentially useful indicators of physical environment owing to the varied growth habits of the colonies and the observed environmental significance of comparable growth habits in living species. L. W, Stach $(1935,1937)$ studied zoarial forms of living Bryozoa with reference to different environments and separated them into "(a) stable forms and (b) unstable forms" (Stach, 1937, p. 80). Zoaria in the first group are incapable of modifying their growth form, regardless of environment or changes in environment. "The stable zoarium therefore cannot adjust itself to or survive adverse environmental conditions, and is consequently restricted to definite habitats." The unstable types are capable of modifying their zoarial growth habit in response to the environment. For example, a species that is normally ramose ("vinculariform") and vertically elongated in quiet waters becomes incrusting ("membraniporiform") in strongly agitated waters (Stach, 1937, p. 82).

The developing zoarium of a species with an unstable zoarial form apparently has a tendency to assume an erect slender form which, in quiet water, will enable it to extend through a greater volume of water from which to obtain food. When the larva of such a form is carried into a zone where the motion of the water is strong, the uncalcified growing points are unable to assume an erect position and are kept flattened to the substratum, and are thus forced to assume a membraniporiform habit, the continual movement of the water ensuring adequate food supply and aeration.

The principle of stable and unstable growth forms for bryozoan species appears to be valid in the Hamilton trepostomes, since some species show two growth habits in the same zoarium and in different zoaria and other species display constant growth forms. Species with unstable growth habits include: Leioclema confertiporum (pl. 3) with incrusting and subramose habits in separate zoaria; Leptotrypella multitecta (pls. 7, 8), L. furcata (pl. 11), L. amplectens (pl. 12, figs. 1-5), Atactotoechus acritus (pl. 17, figs. 1-5), and Loxophragma lechrium (pl. 22) all exhibiting incrusting and ramose growth habits in the same and separate zoaria. Until proved otherwise, however, most of the Hamilton species must be considered as stable species existing in a constant growth habit.

The possible application of the stable and unstable concept of colonial growth habit of bryozoans to paleoecology requires considerably more data than are now available. The incrusting mode of growth in itself has little significance, for incrusting species belonging to stable groups can occur in both quiet and rough water. But the absence of vertically extended branching zoaria in addition to the dominance of incrusting. forms would be suggestive of a rough-water environment. The coral-bearing limestone facies of the Hamilton group (p. 9) is an example. If the incrusting forms belonged to unstable species that were also known to be branching, their occurrence in the absence of ramose forms would suggest rough water more strongly. The occurrence of branching forms, especially branching forms of species known to be of the unstable group, would suggest a relatively quiet water environment. The more robust branching colonies would have greater physical strength to resist rough water and would be a weaker argument for absolutely quiet water. If both ramose and incrusting growth habits of unstable species occur together, it could mean that the environment alternated between water quiet enough for branching growth and rough enough to require incrusting growth. The calcareous mudstone facies of the Hamilton group (p. 10) contains ramose forms of species that are found in minor numbers in incrusting growth habits. Such occurrences, with other types of evidence such as the general lack of transportation of fragments of the colonies after death, suggest a generally quiet water environment with minor areas or times of rougher water. 


\section{IITHOFACIES AND BRYOZOAN FAUNAS OF THE} HAMILTON GROUP

The general distribution of bryozoan faunas of the Hamilton group is closely correlated with lithofacies (rock types). Stratigraphic application of these faunas requires recognition of at least the major environments and their geographic and inferred time relationships.

In the outcrop area of the Hamilton group between Lake Erie and Cayuga Lake are five major lithofacies, each with a characteristic fauna. Both vertical and horizontal transitions between lithofacies and their associated faunas are common within the members of the formations in the Hamilton group. Trepostomatous bryozoans have not been found in two of the lithofacies, occur in small numbers in two others, and are abundant in the fifth.

Dark shale facies.-This facies is characterized by black to medium-gray well-bedded shale. No trepostomes have been found. The dark shale fauna is meager, and the number of species is restricted. It has been called the "Marcellus" or "Leiorhynchus" fauna by Cleland (1903) and Cooper (1930). The typical "Leiorhynchus" fauna listed by Cleland (1903, p. 23) includes Leiorhynchus, Chonetes, Orbiculoidea, Strophalosia, Lunulicardium, Nuculites, Nucula, Styliolina, Tentaculites, and Phacops.

The dark shale facies is best developed in the Marcellus shale, the Levanna shale (of Cooper, 1930) of the Skaneateles shale, and the Ledyard member (of Cooper, 1930) of the Ludlowville shale. The most extreme development of the dark shale facies is found in the Marcellus. This formation normally is a darkgray to black shale that is fissile and commonly develops platy bedding cleavage. The Ledyard member of the Ludlowville is black and fissile in the Cayuga Lake region and gradually becomes lighter in color and less well bedded to the west.

The black shale facies with its restricted fauna is ordinarily interpreted to indicate unfavorable environmental conditions for normal marine assemblages. The general makeup of the fauna suggests a poorly aerated, possibly brackish water environment. Styliolina and Tentaculites (Wells, 1947, p. 123, 124) might be considered planktonic forms living in the surface waters. The remainder of the fauna was benthonic, living on and in black, organic, oxygen poor muds.

Sandstone facies.-Sandstones are rare in the Hamilton group between Lake Erie and Cayuga Lake, but more common eastward. The trepostomatus Bryozoa do not occur in the sandy beds and thus are generally rare east of Cayuga Lake. The fauna of the sandstones is characterized by an increase in the number of pelecypods and a relative decrease in the number of brachiopods as compared with the siltstone and calcareous mudstone facies to the west.

Siltstone facies.-The siltstone facies might be considered to represent a transitional environment between the optimum environment of the calcareous shale and apparently inhospitable environment of the sandstone. Cooper's King Ferry shale member of the Ludlowville is a typical representative of this lithofacies in the Cayuga Lake region. The trepostomes of the siltstone facies are few. Of the 15 species occurring in the Wanakah shale member as used by Buehler and Tesmer, Tichenor limestone member, and Deep Run member of Cooper, the westward equivalents of the King Ferry, only 6 occur in the siltstones of the King Ferry. One species, Atactotoechus parallelus is known only from the King Ferry member but is very rare.

The lack of trepostomes in the sandstone facies and their restricted occurrence in the siltstone facies is at least in part due to lack of adequate substrate for attachment of the zoaria. Duncan (1957, p. 784) states that-

shifting sands and muddy bottoms without admixture of larger debris are not suitable for fixation of most larvae *** The general absence of bryozoans in most marine sandstone and some shale is attributable in large part to lack of objects for attachment.

Coral-bearing limestone facies.-The limestone facies is typically developed in the Centerfield limestone and Tichenor limestone members of the Ludlowville shale. The limestones are largely of organic origin, displaying large colonies of Favosites, large solitary corals such as Heliophyllum and Cystiphyllum, incrusting fistuliporoid Bryozoa, and many species of well-preserved brachiopods. This fauna of relatively large, massive specimens is surrounded by a clastic limestone matrix consisting of crinoid columnals and the broken debris of fenestellid bryozoans and other fragile fossils.

Trepostomatous Bryozoa are very rare in the limestone beds and gradually increase in numbers as the limestone becomes more shaley and approaches the composition of a calcareous shale or mudstone. Trepostomes occur in the shale partings in the limestone members. Examples of transitions to normal calcareous shales are common both vertically and horizontally. As the Centerfield becomes more impure and muddy eastward in the Finger Lakes region (p. 3), the trepostomes increase in number. Trachytoechus variacellus and Polycylindricus clausus are few in number west of the Finger Lakes region but occur abundantly at Cayuga Lake. The fauna of the basal mudstone and shale in the Tichenor shows a gradual 
vertical change from the fauna of brachiopods and ramose trepostomes of the underlying Wanakah to the fauna of corals and incrusting fistuliporoid bryozoans of the Tichenor.

The coral-bearing limestone facies seems to represent a shallow, rough-water environment. The comminuted debris of the more fragile elements of the fauna, the massiveness and apparent physical strength of the well preserved forms, and the predominance of low, incrusting fistuliporoid Bryozoa over ramose trepostomes all support this interpretation.

Calcareous mudstone facies.-Optimum environmental conditions for trepostome development were afforded by the light-gray calcareous mudstones and shales of the Hamilton group. Sediments of the mudstone facies that contain abundant macrofossils are characteristically an alternation of 1 - to 3 -inch beds of concentrated fossil material and 1 foot beds of unfossiliferous shale or mudstone. Individual unfossiliferous zones have a considerable range in thickness and a few fossiliferous concentrations develop 1-foot thicknesses in discontinuous lenses. Some of the thin fossiliferous beds consist of comminuted fossil debris, others contain whole specimens showing little sign of wear or transportation. Also within the calcareous mudstone facies are relatively large thicknesses of homogeneous mudstone and shale that contain few macrofossils.

The Wanakah shale member consists of calcareous shale and mudstone throughout. The important faunal zones in the Wanakah-such as the Strophalosia zone, the Pleurodictyum zone, the trilobite zones, and the Stropheodonta demissa zone-are all examples of the thin beds of concentrated fossil material. The intervening thicknesses of the Wanakah member generally consist of the homogeneous shales and mudstones showing few fossils. From the Genesee Valley region to Seneca Lake, Cooper's Kashong member and the Windom member of the Moscow shale are characterized throughout their thicknesses by the alternating thin fossil beds and unfossiliferous shales. The Windom member extends eastward to Cayuga Lake displaying similar alternations and abundant macrofaunas.

In all occurrences of ramose trepostomes found in place in the sediments of the mudstone facies the broken pieces of the branches are in zoarial groupings. Most commonly the fragments occur in lense-shaped or irregular masses as if the zoaria were compressed by the weight and compaction of the sediments without otherwise being moved from their living position. A few zoaria are oriented either perpendicularly or parallel to the bedding without any differential move- ment of the constituent fragments. Most zoaria seem to have originated in the thin fossiliferous beds. Very rarely a zoarium can be followed vertically from one thin fossiliferous bed, through an unfossiliferous mudstone, and into the superjacent fossil concentration.

The fauna that is characteristically associated with the trepostomes in the calcareous mudstone facies includes a number of brachiopods. Especially common are spirifers, Athyris spiriferoides (Eaton) and species of Stropheodonta. Small horn corals, species of the small colonial coral Pleurodictyum, the ramose favositid genus Trachypora, and a few auloporoid corals are commonly associated with the trepostomes.

John L. Rich (1951) suggested two slightly different hypotheses for the origin of the thin limy fossiliferous beds and the interbedded unfossiliferous mudstones. If a slight difference in depth is assumed between the depositional surface and wave base the deposits could have been affected by wave action during storms. The temporary lowering of wave base would have winnowed the mixture of mud and bottom life placing at least the finer muds into suspension. As a result a concentrate of benthonic life would be left on the bottom. After storms the fine muds settled again forming a relatively unfossiliferous layer resting on the thin fossiliferous zone (Rich, 1951, p. 5).

The alternative origin (Rich, 1951, p. 18) seems more plausible when applied to the thin zones that contain relatively unbroken fossils and ramose colonies in growing position. Lag concentrates might have formed (Rich, 1951, p. 13) consisting of “**** fossil shells $* * *$ concentrated locally as a result of contemporaneous nondeposition of the finer sediments in which they would normally have been bedded." Thus, abundant benthonic communities would be formed during periods of bypassing of terrigenous muds under normal but variable current or wave action.

Whatever the mode of origin, physical conditions were repeated many times during deposition of the shales of the Ludlowville and Moscow formations. Wave or current action was not generally strong enough to prevent growth of branching colonies or to transport the colonies after their death. The colonies were robust enough, however, and possessed of enough strength so that some current or wave action cannot be completely ruled out. It is not uncommon to see more fragile shells badly broken in the matrix surrounding a nearly complete branching zoarium.

In thicker beds of shale and mudstone that do not contain the thin limy zones, the fauna appears to be scarce. The scarcity of fossils in the homogenous shales may be real or merely reflect the difficulty of finding the specimens that could be scattered evenly 
through the rock. In either case, deposition of muds seems to have been too rapid and continuous to allow benthonic faunas to form coquinoid concentrations.

\section{TIME AND STRATIGRAPHIC RELATIONS}

Several of the lithologic and faunal features of the rocks of the Hamilton group suggest a means of relating the rocks within the group to their relative time of deposition. If correctly interpreted, such time relationships are extremely useful in the taxonomic evaluation of morphologic characteristics that would otherwise be difficult to understand.

The Hamilton group contains several extremely thin beds, measured in inches, characterized by coquinoid concentrations of one to several species that can be traced for many miles along the outcrop (p. 10). Examples include the Strophalosia beds (Cooper, 1930, p. 225) at the base of the Wanakah member that can be traced from Lake Erie to the Genesee Valley area, and the trilobite beds (Cooper, 1930, p. 225) that are traceable from Lake Erie to Canandaigua Lake.

Distinctive lithologic units are a second feature of the Hamilton group and are also widespread geographically. Examples are the Centerfield limestone member of the Ludlowville that extends from the Depew quadrangle to Canandaigua Lake with little lithologic change. The Tichenor limestone member of the Ludlowville and the Menteth limestone member of the Moscow shale have essentially the same lithology over comparable areas. The nodular zone near the top of Cooper's Kashong member of the Moscow in the Finger Lakes region is another widespread lithologic zone. These lithologic units are generally stratigraphically parallel to the thin coquinoid beds mentioned in the preceding paragraph.

Superimposed on the pattern of the widespread lithologic units of the Hamilton rocks are the zonules, locally recognizable biostratigraphic units, based upon morphologically distinct species of trepostomatous Bryozoa. These zonules are widespread geographically and are parallel to the thin lithologic units and the coquinoid beds of the preceding paragraphs. Further, these zonules are wholly contained within individual named members of formations of the Hamilton group. Examples of easily identifiable species on which zonules are based include: Trachytoechus variacellus, found only in the Centerfield limestone member of the Iudlowville (the only species of Trachytoechus in the Hamilton group) ; Polycylindricus asphinctus, occurring in the Wanakah shale member as used by Buehler and Tesmer from Lake Erie to the Genesee Valley area and easily distinguished by the lack of an internal cylinder (p. 68) ; Leptotrypella asterica, the dominant bryozoan species in the Krashong member of the Moscow shale that occurs very rarely in the Ludlowville shale below (three Ludlowville specimens identified); Leptotrypella furcata and Atactotoechus fruticosus, two species with easily recognized morphologic characteristics that are known only from the Windom member of the Moscow shale. L. furcata occurs throughout the thickness of the Windom and is found abundantly from the Attica quadrangle to Owasco Lake. A. fruticosus occurs between the Genesee Valley and Cayuga Lake.

In addition to the morphologically distinct group of species for which zonules are named, several genera show morphologic trends that are considered to be evolutionary in origin. The same stage of evolution, morphologically defined, in any one lineage, occurs at the same stratigraphic position, as defined by the marker beds and by the zonules of distinctive species.

As a result of the noted alinement, marker beds, zonules, and evolutionary stages are considered to be isochronous throughout the area studied. Therefore, the named stratigraphic members defined primarily on marker beds are considered to be parallel to time lines.

If it were possible to assume fairly constant rates of speciation for the bryozoan lineages discussed in this paper, a rough estimate could be made of the relative amounts of time represented by the members and the periods of nondeposition between the members. Such an estimate would indicate that considerably more time elapsed between the Kashong and Windom members with their distinct faunal differences than between the Centerfield and Ledyard members or between the Ledyard and Wanakah members, both showing only subspecific differences in two genera. Also, there is a strong indication that less time is represented by the preserved sediments than the intervals of nondeposition in the Hamilton group. Unfortunately, the assumption that time is uniformly proportional to morphologic change in phylogenetic lineages probably is not defendable when applied to a problem in such detail.

The paleogeographic setting for the Hamilton deposits would no doubt clarify and explain many factors in the time and stratigraphic relationships of the beds. Data on the location of the margin of the basin of deposition nearest the western and central New York area would be of considerable help. Unfortunately, the writer knows of no acceptable evidence establishing the position or positions of such a strandline. Grabau (1917, p. 950) inferred the Buffalo axis, running through the Lake Erie region in a generally northeast direction, to explain the westward thinning of the Hamilton group and superjacent Tully lime- 
stone in New York. There is no evidence, however, that this axis was subaerial and formed a land barrier between the New York and Ontario basins.

The paleogeographic map of the Skaneateles, Ludlowville, and Moscow formations (Schuchert, 1955, map 36) shows the northern boundary of the Hamilton basin to be generally parallel to the present east-west outcrop of the Hamilton in western and central New York. Such a northern boundary was also suggested by G. A. Cooper (oral communication, 1954) to account at least partly for the nature of the Hamilton rocks and their inferred relations to time. Thus the thin coquinoid layers, the distinctive lithologic units, and the parallel zonules would have their east-west distribution controlled by elongated east-west belts of similar environment that were controlled in turn by distance from the hypothetical northern shoreline. If the belts of similar environment were wide enough in the north-south direction, embayments causing northsouth indentations of the standline and generally parallel shifting of benthonic environments would not be important enough to mask the general east-west continuity of the thin and distinctive sediments. The northern emergent area would be low lying, contributing small amounts of terrigenous material to the basin, in contrast to higher lands in the emergent area east of the present Hamilton outcrops that contributed more and coarser clastics, as reflected in the Hamilton rocks of eastern New York.

Another plausible hypothesis for the paleogeographic setting of the Hamilton would place the western and central New York region in the center of the basin without shoreline control. The rocks now exposed in outcrops could have been part of the deposits of a large equidimensional area of generally equal benthonic environment during any one period of time. Subsurface investigation could yield information that would effectively test this hypothesis.

\section{EVOLUTION}

Species of the trepostomatous Bryozoa of the Hamilton group can be divided into two groups according to their morphologic distinctness and observable phylogenetic relationships. One group of species shows no taxonomically important morphologic change in time or space and is easily recognizable. A second group of species demonstrates transitional morphologic changes or trends in time and space that are considered to be of taxonomic value. This second group of species, plus a limited number of the morphologically distinct species that contain comparable morphologic features, have been arranged into inferred phylogenetic lineages (see Leptotrypella, p. 52, 63, figs. 23-24; Atactotoechus, p. 70, figs. 25, 26; and Loxophragma, p. 79, fig. 27; for more detailed discussions).

The morphologically distinct species are stratigraphically short or long ranging. The easily recognized species of restricted stratigraphic range are ideally suited for the establishment of zonules (see p. 11). Species that are long ranging include Dyoidophragma polymorphum, occurring from the Centerfield limestone member of the Ludlowville to the Windom member of the Moscow; Leioclema decipiens, ranging from the Wanakah shale member of the Ludlowville to the Kashong member of the Moscow; and Leptotrypella magniporta, ranging from the Wanakah to the Windom member of the Moscow shale at the top of the Hamilton group.

Species of the group containing transitional forms are short or long ranging in time and develop recognizable morphologic changes considered to be of taxonomic value within the time of the Tioughnioga stage of Cooper. These gradual morphologic changes with time permit the recognition of phylogenetic lineages. Species and subspecies of a phylogenetic lineage generally are difficult to recognize because of a few transitional forms. In this paper the placing of morphologically transitional zoaria into taxons is based on the essentially isochronous nature of each member of the Hamilton group. A group of zoaria from a member that shows variation about a central tendency and morphologic characteristics that are transitional with taxons in adjacent members, is considered an interbreeding complex and a single taxon in a restricted interval of time. Therefore, a species or subspecies contains the zoaria of the plexus or phylogenetic lineage that are closely related in time as well as in morphology.

The grouping of the zoaria of a phylogenetic lineage into species and subspecies partly on the basis of occurrence in time and statigraphic units in the Hamilton group results in some morphologic overlap between taxons if evolution is slow relative to the vertical representation of the available fossil record.

The alternative solution to the treatment of morphologically transitional or overlapping forms from several superimposed zones would be the differentiating of species wholly on morphology, resulting necessarily in arbitrary morphologic boundaries for taxons without regard for time and stratigraphic relationships. It is believed that consideration of time and stratigraphic occurrences and the recogition of possible phylogenetic lineages as indicated by morphologic trends is the more natural and statigraphically useful basis for the solution of otherwise confusing taxonomic problems. 


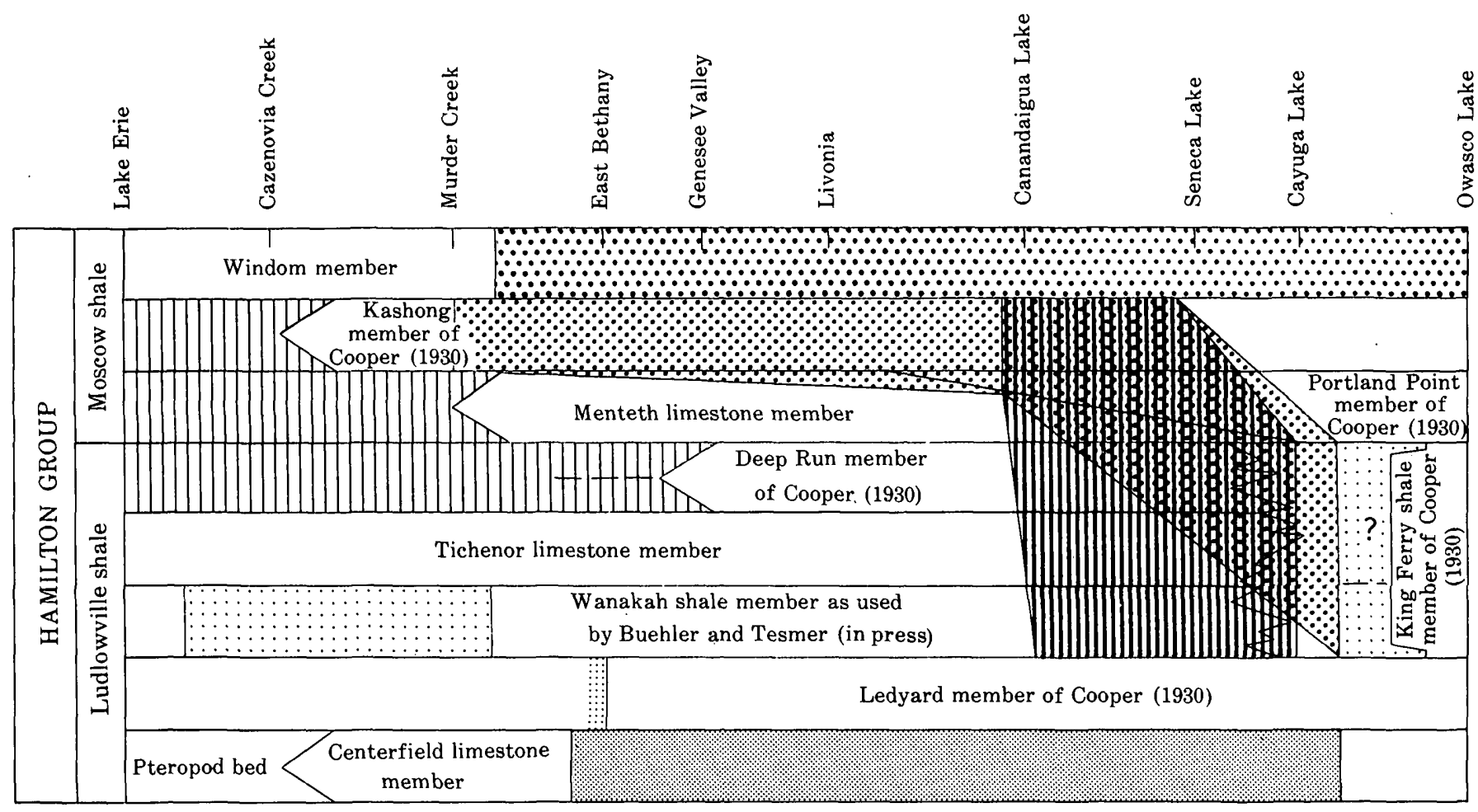

\section{EXPLANATION}

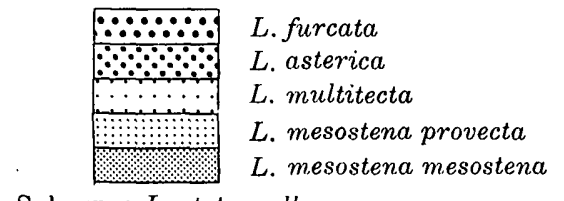

Subgenus Leptotrypella

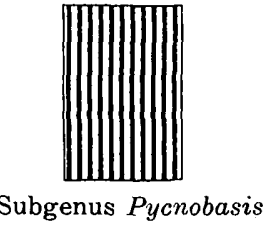

Subgenus Pycnobasis

Figure 4.-Time-space diagram of the occurrence of the genus Leptotrypella in the Hamilton group of New York. The members of the Ludlowville and Moscow formations are arranged relative to their inferred time and geographic position (modified from Cooper and others, 1942); time lines are horizontal, geographic position along the east-west outcrop belt of the Hamilton group is indicated by the place names at top of diagram. The superimposed polygons are defined by, and include, all known occurrences of the subgenus (Pycnobasis) and the species of (Leptotrypella) that are discussed phylogenetically in this paper.

\section{TIME AND SPACE RELATIONS OF LINEAGES}

Figures 4 and 5 .depict the inferred time and space relations of some of the species involved in phylogenetic lineages. A polygon is drawn about the outermost points of occurrence of collections that are located by plotting their inferred time, taken from stratigraphic data, against their known geographic position. The geographic positions can be fairly accurately represented in the plane of the chart because of the fortuitously linear configuration of the outcropping area of the Hamilton rocks.

Two species showing overlapping areas on such a time-space chart, are potentially sympatric in occurrence during the time and in the region represented by the overlap. Unfortunately, an overlap obtained on such a basis does not definitely demonstrate a sympatric relationship. The large polygon representing A. acritus in fig. 5 no doubt has little reality in indicating the actual occurrence of the species in time and space within the outcrop area. The collections themselves give a minimum representation of the occurrence of a species. Expansions and contractions of east-west geographic occurrence with time could very well have occurred, giving the eastern and western margins of the polygons many fluctuations. There could have been geographic areas of nonoccurrence in the outcrop belt during any time unit. In addition, migrations completely out of the outcrop area and back again were possible during the time unit represented by the surviving sediments. Sympatric existence is indicated only when two species are commonly found in the same beds over a considerable area.

The range chart (p. 16) shows that Leioclema confertiporum and $L$. decipiens occur together in two geographically widely separated collections in the Wanakah shale member of the Ludlowville, indicating that the species were probably sympatric. Lack of morphologically transitional specimens precludes plac- 


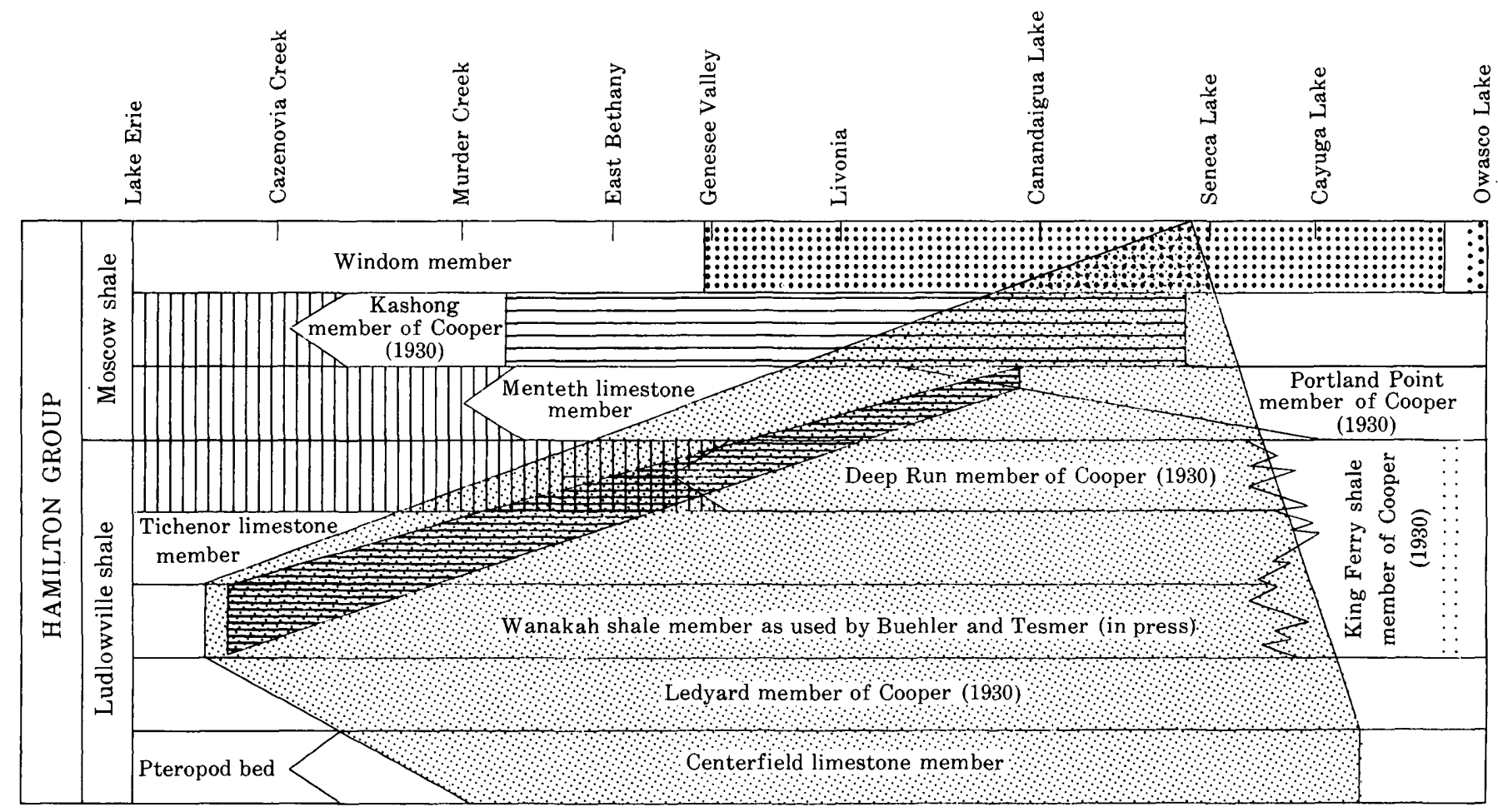

\section{EXPLANATION}

A. cartus pilatus
A. cartus cartus
A. acritus

\begin{tabular}{ll}
$\because \because \because \because \because \because$ & A. hystricosus \\
\hdashline$\vdots: \vdots \vdots: 0$ \\
\hdashline$: \vdots:$ & A. fruticosus \\
\hdashline$:$ A. parallelus
\end{tabular}

FigURE 5-Time-space diagram of the occurrence of the genus Atactotoechus in the Hamilton group of New York. The members of the Ludlowville and Moscow formations are arranged relative to their inferred time and geographic position (modified from Cooper and others, 1942). time lines are horizontal, geographic position along the east-west outcrop belt of the Hamilton group is indicated by the place names at top of diagram. The superimposed polygons are defined by, and include, all known occurrences of the species of the genus Atactotoechus.

ing these two species in a single species. Leptotrypella multitecta, L. amplectens, and L. magniporta occur together in 1 locality in the Wanakah member, and L. multitecta occurs in 2 other collections with $L$. magniporta and in 3 other collections with L. amplectens. There is no morphologic evidence of phylogenetic connections between the 3 species, and the environmental niche of $L$. amplectens was certainly highly specialized (p. 61) and different from the other 2 species. Leptotrypella asterica occurs in 2 collections with $L$. multitecta, 1 collection from the Wanakah member of the Ludlowville, the other from the partly equivalent King Ferry member, so these 2 species may well have been sympatric before $L$. asterica became prolific in the Kashong member of the Moscow. The few other instances of any 2 species of the same genus in the same collection are single occurrences and their possible sympatric relationships cannot therefore be demonstrated.

On the basis of known occurrence, the bryozoan fauna of the Ledyard member of the Ludlowville was geographically restricted within the Hamilton area to the White Creek locality, represented in figure 4, by the pattern for L. mesostena provecta. Atactotoechus acritus also occurs in the Ledyard at that locality so the polygon for $A$. acritus in figure 5 might better be indented to that single locality at the level of the Ledyard member. The generally unfavorable environment of the Ledyard sediments (p. 9) and resulting geographic restriction is accompanied by recognizable morphologic changes in several lineages. Conceivably, the generally unfavorable environment could have started the evolutionary trends recorded in the single White Creek collection and continued in the subsequent Wanakah deposits. Besides the intermediate subspecies Leptotrypella mesostena provecta (p. 56), the Atactotoechus cartus lineage probably started in the Ledyard (p. 70) and the Loxophragma leptum-L. lechrium lineage contains intermediate zoaria from the Ledyard member (p. 79).

The time-space diagram of Leptotrypella (fig. 4) and Atactotoechus (fig. 5) suggests a certain amount of geographic localization of speciation within the trepostomes (see also p. 81). All four of the species 
of the subgenus L. (Pycnobasis) are limited geographically to the Finger Lakes region. L. (Leptotrypella) asterica.first appeared in the King Ferry member of the Ludlowville at Cayuga Lake and spread westward out of the Finger Lakes area during the deposition of the Kashong member of the Moscow, where it became abundant. Atactotoechus parallelus and $A$. hystricosus are limited geographically to the Cayuga and Owasco Lake areas.

An explanation for the apparent geographic restrictions of these morphologically distinct forms is suggested by the proximity of the eastern limit of the occurrence of the trepostome fauna. The amount of silt and sand in the sediments increases very gradually in the Finger Lakes area and extends eastward, becoming the dominant lithology. No doubt the influx of silt and sand was effective in limiting the eastward occurrence of trepostomes and could have produced an eastward-changing environment within the Finger Lakes region that influenced speciation.

The changing environment of the Finger Lakes area was not unfavorable to several species of trepostomes that grew abundantly there in Tioughnioga time. Trachytoechus variacellus and Polycylindricus clausus are abundant in the Centerfield limestone member at Cayuga Lake, Leptotrypella multitecta is fairly common in the siltstones of the King Ferry member at Cayuga Iake, and Leptotrypella furcata and Atactotoechus fruticosus are abundant in the Windom member in the Finger Lakes area as well as further west. As might be expected, different lineages and species had different ecological requirements and tolerances.

\section{MORPHOLOGIC TRENDS OF LINEAGES}

Size increase in phyletic lineages has been cited as a common evolutionary trend (Newell, 1949). Inferred phylogenetic lineages of three genera, Leptotrypella, Atactotoechus, and Loxophragma, reveal a common tendency to progressive increase in size of the branches and lengths of the zooecia. Species of the three genera in the oldest member, the Centerfield limestone member of the Ludlowville, display branches relatively small in diameter and zooecia that contain relatively small maximum numbers of diaphragms in correspondingly narrow ephebic zones. Stratigraphically higher in the section the zoarial branches generally increase in diameter within individual lineages.

The increase in total diameter is largely a result of an increase in the diameters of the neanic zones that in turn are controlled by the number of zooecia in the branches. In addition to the increase in the diameters of the neanic zones, the ephebic zones show a general increase in their maximum widths and the maximum numbers of diaphragms. These general size increases are conveniently expressed in the axial ratio-the ratio of the neanic diameter to the total diameter. Since the increase of the neanic diameter is proportionally greater than the ephebic width increase in the lineages, and the total branch diameter consists of the ephebic width plus the neanic diameter, the axial ratios became larger with time. The axial ratio is still more useful if plotted against the corresponding number of zooecial diaphragms, a measure of the growth stage of the individuals in a colony, to form scatter diagrams.

The Leptotrypella mesostena-multitecta lineage (p. 52) demonstrates such a size increase. Figure 24 shows the maximum number of diaphragms of $L$. mesostena to be 7 , the maximum number of diaphragms for $L$. multitecta is 12 . The shift to the left in the diagram of the plotted points from $L$. mesostena to L. multitecta reflects the size increase in the lineage. Parallel increases occur in the $L$. mesostena-L. amphelicta lineage (p. 63) and the Loxophragma leptum-L. lechrium lineage (p. 79, fig. 27). The same shift to the left of the axial ratios is revealed in figure 26 for the Atactotoechus acritus-A. hystricosus lineage. However, the intervening species, $A$. parallelus developed a slightly higher number of diaphragms than the species from the Windom so the gradual increase in the maximum number of diaphragms with time is not strictly followed in this lineage, according to the data presently available.

Some of the morphologic characters developed in species of Leptotrypella (Pycnobasis) (p. 62) approach characters typically found in Atactotoechus (p. 69) and Loxophragma (p. 78), two genera that probably belong in a different family. The compound structure and the configuration of the diaphragms that appear in L. (Pycnobasis) are considered an example of parallel evolution. Aside from this similarity with the diaphragms of Atactotoechus and Loxophragma there are no morphologic characteristics to indicate possible phylogenetic connections between the subgenus $L$. (Pycnobasis) and the two atactotoechid genera.

\section{COMPARISON OF TREPOSTOMATA FROM HAMILTON AND TRAVERSE GROUPS}

The only Middle Devonian trepostome fauna thoroughly studied using thin sections is that of the Traverse group of Michigan (Duncan, 1939). The New York and Michigan faunas are so different in named species that little or no detailed stratigraphic correlations can presently be established between the two areas on the basis of comparable assemblages. The lack of species common to the two stratigraphic groups is no doubt explained in large part by differing age. The Devonian correlation chart (Cooper, 1942) 


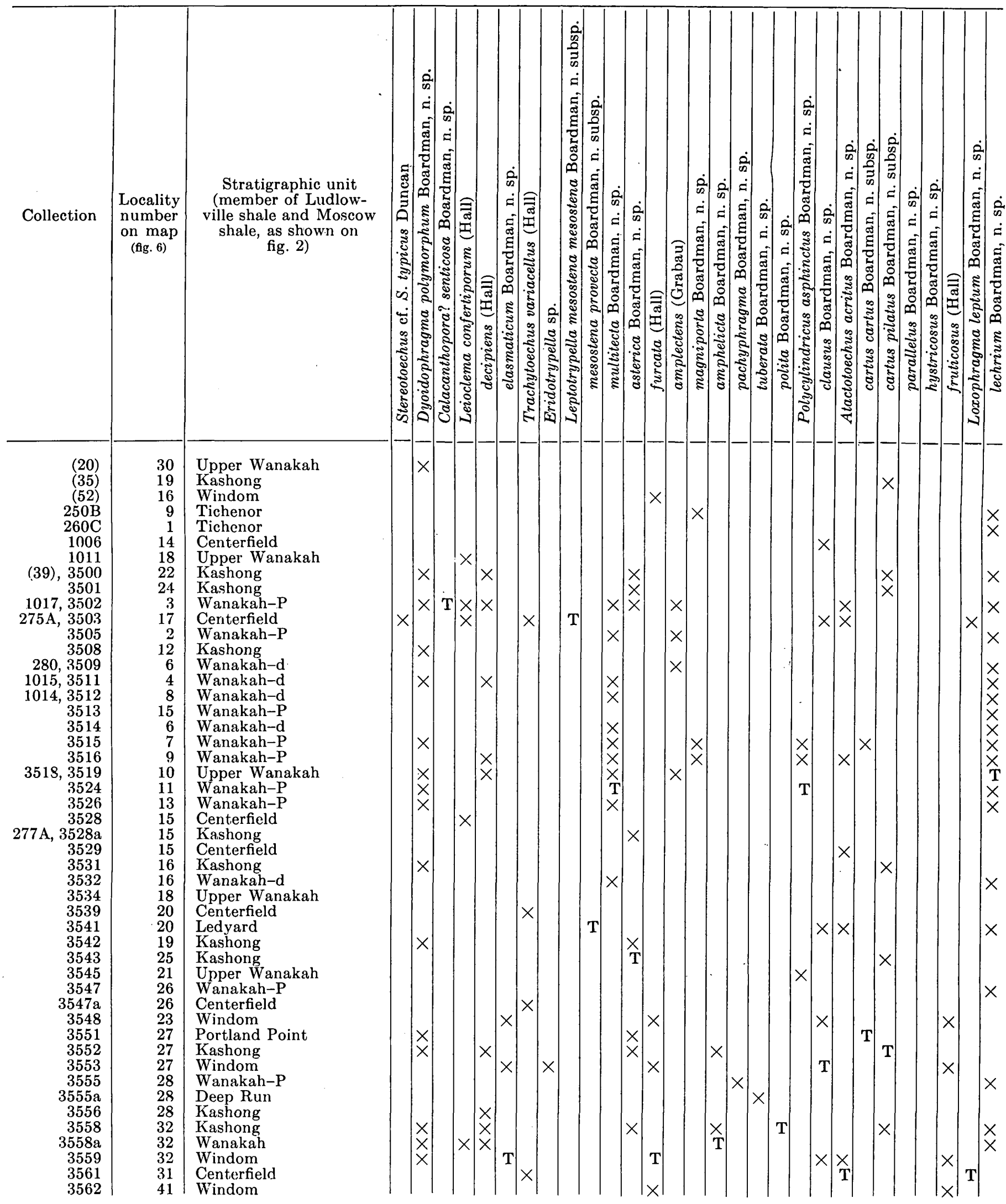




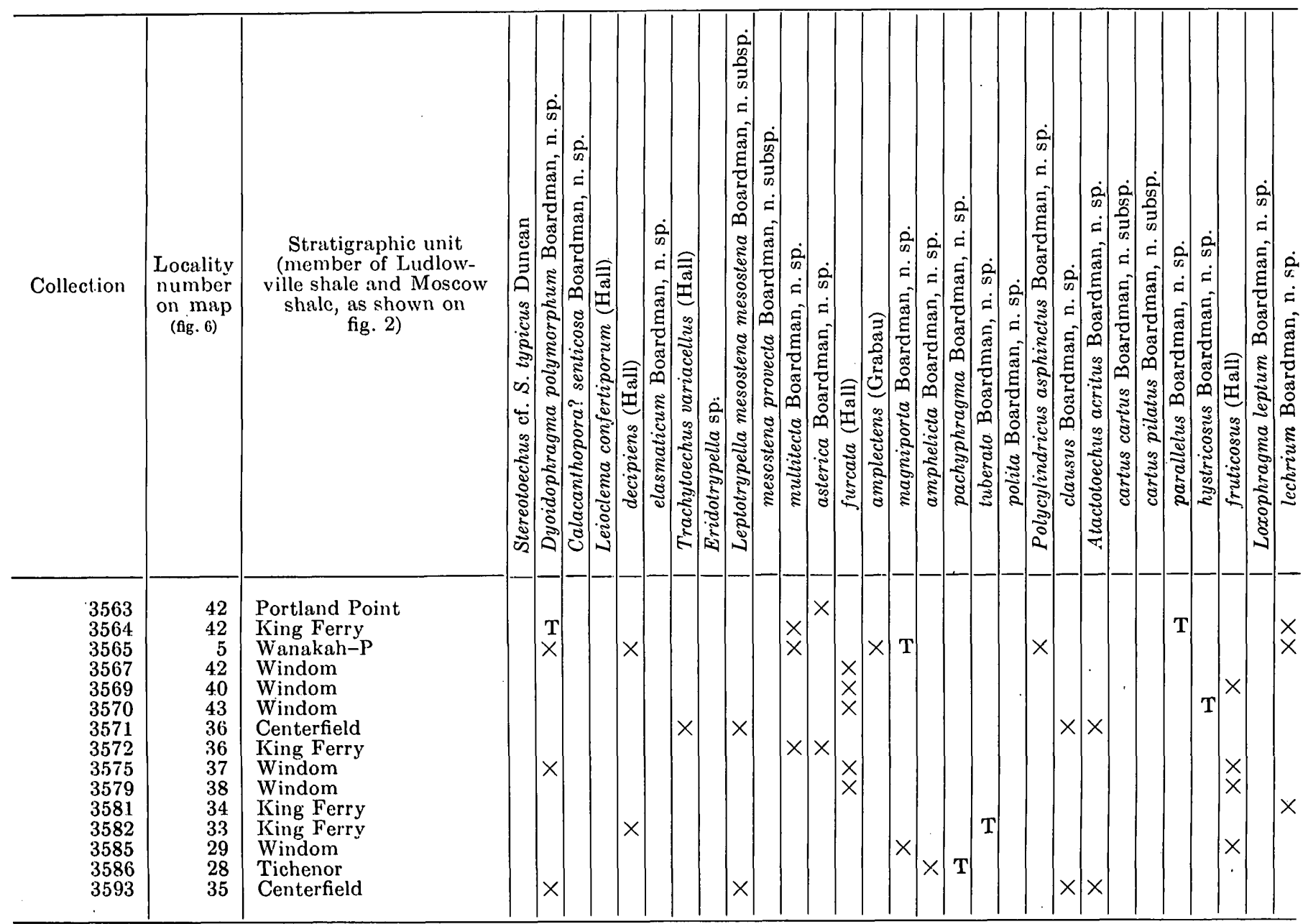

Wanakah $-\mathrm{d}=S$. demissa zone

Wanakah-P $=$ Pleurodictyum zone

$\mathrm{T}=$ type locality.

indicates that the Centerfield limestone and Wanakah shale members of the Ludlowville shale are the only trepostome-bearing members of formations in the Hamilton that have time and rock equivalents in the Traverse group.

Comparison of the Traverse and Hamilton faunas at the species level reveals only one species now considered to be common to both groups. Leioclema decipiens (Hall) is considered to be conspecific with $L$. traversense Duncan and $L$. attenuatum Duncan (see p. 47). Unfortunately, L. decipiens is a fairly long ranging species in the Hamilton group, occurring in the Wanakah and King Ferry shale members of the Ludlowville shale and the Kashong member of the Moscow shale. The holotype of $L$. traversense comes from the Norway Point formation, which is correlated with the Wanakah member, and the holotype of $L$. attenuatum comes from the Potter Farm formation, which is considered to be slightly younger than the Windom member at the top of the Hamilton group.
The lack of trepostome species common to both the Traverse and Hamilton groups is paralleled by a similar lack of common species in the brachiopod fauna (G. A. Cooper, oral communication, 1956). In addition to different ages for some of the stratigraphic units of the 2 groups, differences of environment or partial or complete physical separation of the 2 basins could have contributed to the faunal differences.

Measurements (p. 53 and fig. 24) of the holotype specimen of the species of Leptotrypella described by Duncan (1939) from the Traverse group of Michigan give a preliminary indication that branch size defines stages of evolution that have some time significance in the Traverse as well as in the Hamilton groups. All of the Traverse species of Leptotrypella come from formations now considered equivalent to the New York Skaneateles shale (Cooper, 1942). The table (p. 53) indicates that neanic diameters are generally comparable to those of $L$. mesostena mesostena, the sub- 
species occurring in the Centerfield limestone member at the base of the Ludlowville shale, and are noticeably less than the neanic diameters of specimens from the younger Ludlowville species. Figure 24 indicates the older Michigan species generally developed more advanced growth stages than Centerfield species, but otherwise developed approximately the same evolutionary level, as expressed by diaphragm-axial ratio plots.

\section{REGISTER OF LOCALITIES}

The following is the list of collection numbers in numerical order. Opposite each is the appropriate locality number that appears on the index map (fig. 6). All collections except the first 14 were made by the writer and the identifying numbers refer to the Silurian-Devonian catalog of U. S. Geological Survey collections. U.S. National Museum collection numbers are those marked by asterisks. Collections marked with one asterisk were made by G. A. Cooper, those marked with two asterisks were made by $A$. $R$. Loeblich, Jr., and I. G. Reimann.

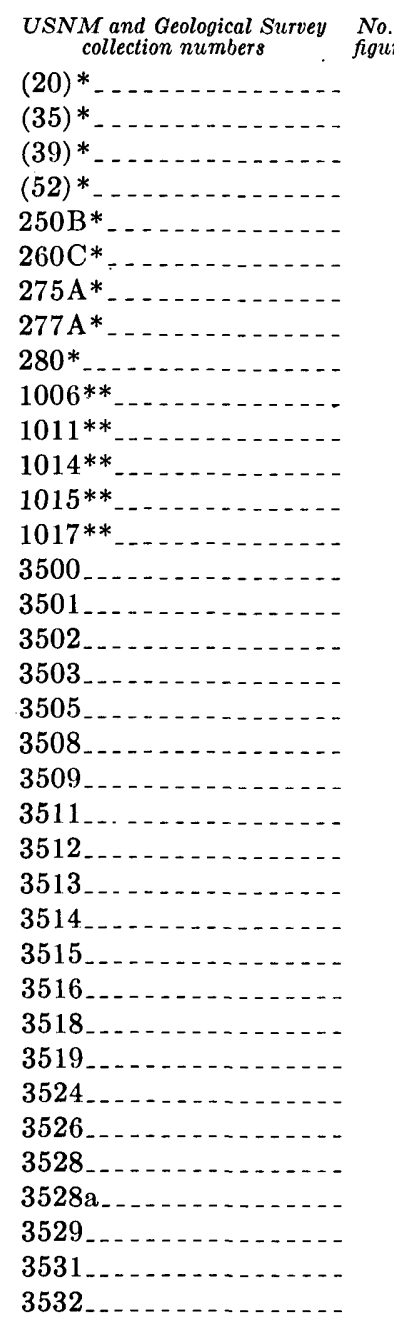

\begin{tabular}{|c|c|c|}
\hline $\begin{array}{l}\text { No. on } \\
\text { figure } 6\end{array}$ & $\begin{array}{l}\text { USNM and Geological Survey } \\
\text { collection numbers }\end{array}$ & $\begin{array}{l}\text { No. on } \\
\text { figure } 6\end{array}$ \\
\hline 30 & 3534 & 18 \\
\hline 19 & 3539 & 20 \\
\hline 22 & $3541 \ldots$ & 20 \\
\hline 16 & 3542 & 19 \\
\hline 9 & 3543 & 25 \\
\hline 1 & 3545 & 21 \\
\hline 17 & 3547 & 26 \\
\hline 15 & $3547 \mathrm{a}_{\ldots}$ & 26 \\
\hline 6 & 3548 & 23 \\
\hline 14 & $3551 \ldots$ & 27 \\
\hline 18 & $3552 \ldots$ & 27 \\
\hline 8 & $3553 \ldots \ldots$ & 27 \\
\hline 4 & 3555 & 28 \\
\hline 3 & $3555 \mathrm{a} \ldots \ldots$ & 28 \\
\hline 22 & 3556 & 28 \\
\hline 24 & 3558 & 32 \\
\hline 3 & $3558 a_{\ldots}$ & 32 \\
\hline 17 & 3559 & 32 \\
\hline 2 & $3561 \ldots$ & 31 \\
\hline 12 & 3562 & 41 \\
\hline 6 & 3563 & 42 \\
\hline 4 & $3564 \ldots$ & 42 \\
\hline 8 & 3565 & 5 \\
\hline 15 & $3567 \ldots$ & 42 \\
\hline 6 & 3569 & 40 \\
\hline 7 & 3570 & 43 \\
\hline 9 & $3571 \ldots$ & 36 \\
\hline 10 & $3572_{2}$ & 36 \\
\hline 10 & 3575 & 37 \\
\hline 11 & 3579 & 38 \\
\hline $\begin{array}{l}13 \\
15\end{array}$ & 3581 & 34 \\
\hline 15 & $3582 \ldots$ & 33 \\
\hline 15 & 3585 & 29 \\
\hline 16 & 3586 & 28 \\
\hline 16 & $3593 \ldots \ldots$ & 35 \\
\hline
\end{tabular}

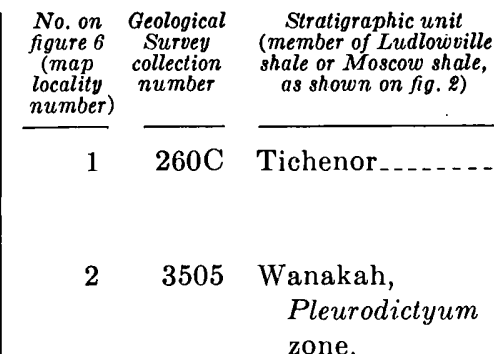

zone.

3 1017, Wanakah, 3502 Pleurodictyum zone.

$4 \quad 1015$, Wanakah, 3511 S. demissa zone.

53565 Wanakah, Pleurodictyum zone.

6280 , Wanakah, 3509 S. demissa zone.

63514 Wanakah, S. demissa zone.

$7 \quad 3515$ Wanakah, Pleurodictyum zone.

8 1014, Wanakah, 3512 S. demissa zone.
9 250B Tichenor....... 3516 Wanakah, Pleurodictyum zone.

10 3518, Wanakah 3519 (Upper).
Description

Eighteen Mile Creek, west of railroad, Eden quadrangle, Erie County.

Road cut and bare interfluvial area between state route 75 and Morse Creek, and just southeast of railroad underpass. Morse Creek is just south of Athol Springs, Buffalo quadrangle, Erie County.

Shale pit between Big Tree Road and first creek north of Athol Springs, and just southeast of railroad, Buffalo quadrangle, Erie County.

Railroad cuts paralleling Rush Creek 0.5 mile north of Big Tree Road, Buffalo quadrangle, Erie County.

Large quarry just west of railroad tracks and 0.5 mile north of Bay View, Buffalo quadrangle, Erie County.

South branch of Smoke Creek at Windom, Buffalo quadrangle, Erie County.

Tributary of south branch of Smoke Creek at Windom. Tributary just north of northeast corner of Windom. Buffalo quadrangle, Erie County.

South branch of Smoke Creek, downstream approximately 0.5 mile from locality 6 .

North Branch Smoke Creek, northeast of Windom 1.25 miles at Berg Road, Buffalo quadrangle, Erie County.

Cazenovia Creek, at Transit Road bridge, 1.5 miles northwest of Spring Brook, Depew quadrangle, Erie County.

North flowing tributary of Buffalo Creek between Bullis Road and railroad. Northeast of Spring Brook, 1.5 miles, Depew quadrangle, Erie County. 


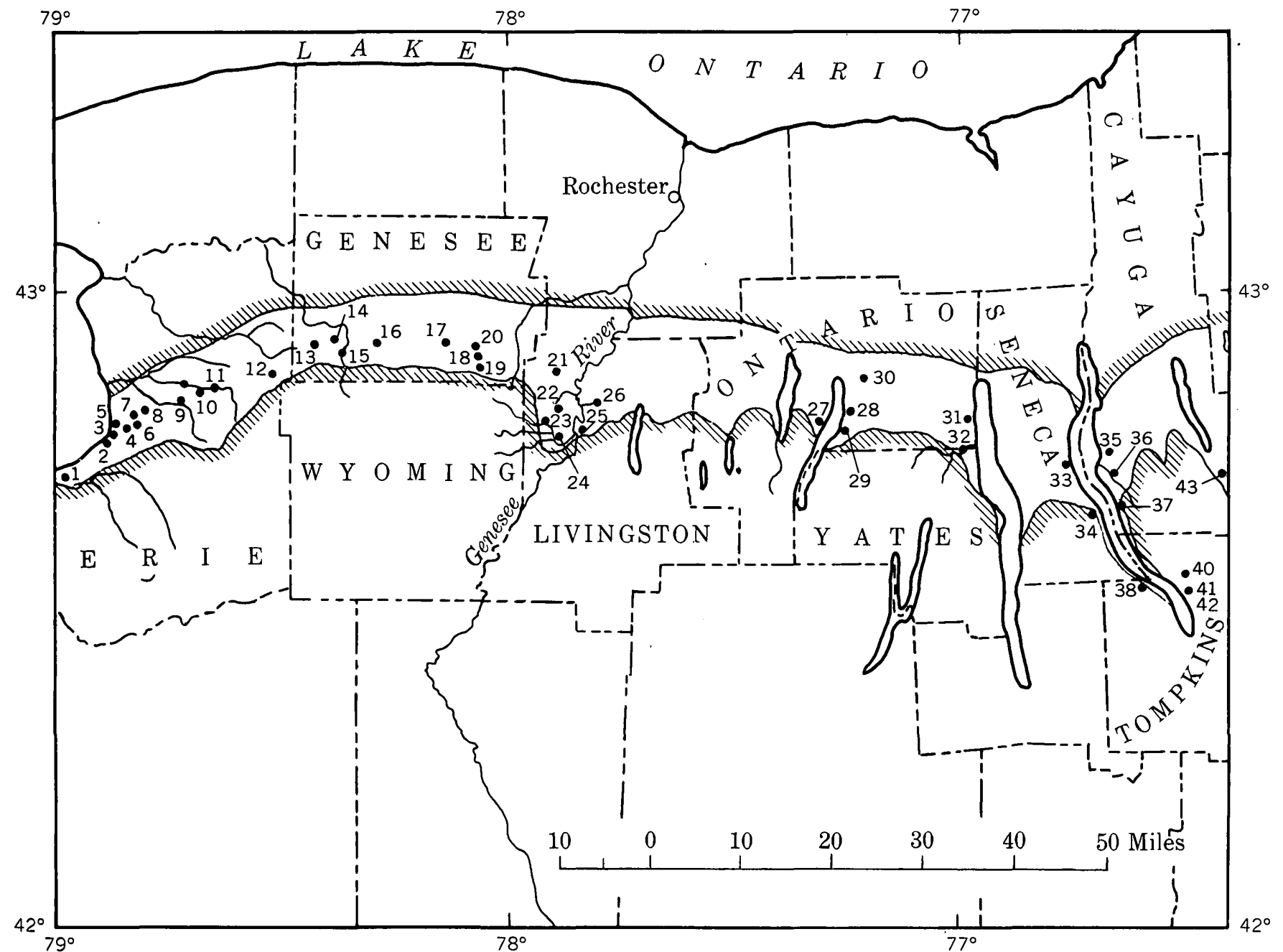

Figurn 6.-Map of western and central New York showing the outcrop location of the Hamilton group, and the collecting locallties.

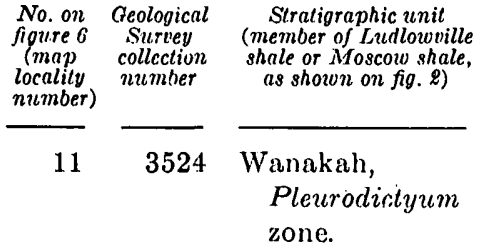

12

3508 Kashong $\ldots . . . .$.

13

3526 Wanakah, Pleurodictyum zone.

\begin{tabular}{|c|c|c|}
\hline $\begin{array}{l}\text { No. on } \\
\text { figure } 6 \\
\text { (map } \\
\text { localily } \\
\text { number) }\end{array}$ & $\begin{array}{l}\text { Geological } \\
\text { Survey } \\
\text { collection } \\
\text { number }\end{array}$ & $\begin{array}{l}\text { Stratigraphic unit } \\
\text { (member of Ludlowville } \\
\text { shale or Moscow shale, } \\
\text { as shown on fig. \&) }\end{array}$ \\
\hline 14 & 1006 & Centerfield _. \\
\hline 15 & 3513 & $\begin{array}{l}\text { Wanakah, } \\
\text { Pleurodiclyum } \\
\text { zone. }\end{array}$ \\
\hline & 3528 & Centerfield \\
\hline & $\begin{array}{r}3528 \mathrm{a} \\
277 \mathrm{~A}\end{array}$ & Kashong \\
\hline
\end{tabular}

Pond Brook, a tributary of Buffalo Creek. South of Elma 0.25 mile, Depew quadrangle, Erie County. West flowing tributary of Cayuga Creek, 1.25 miles SSE of West Alden, Depew quadrangle, Erie County.

Eleven Mile Creek, 1.1 miles north of route 20 at fork in stream. Eleven Mile Creek is 1.7 miles west of Darien Center, Attica quadrangle, Genesee County.
Description

Crooked Creek, 0.5 mile south of railroad and 1.25 miles west of North Darien, Attica quadrangle, Genesee County.

Murder Creek; Centerfield outcrops 1.2 miles north of Darien just west of school, $1 / 4$ mile south of road intersection; Wanakah is north of Darien 0.5 mile, just south of stream intersection with northwest trending road; Kashong is just south of Darien. Attica quadrangle, Genesee County. 


\begin{tabular}{|c|c|c|c|}
\hline $\begin{array}{l}\text { No. on } \\
\text { figure } 6 \\
\text { (map } \\
\text { locality } \\
\text { number) }\end{array}$ & $\begin{array}{l}\text { Geological } \\
\text { Survey } \\
\text { collection } \\
\text { number }\end{array}$ & $\begin{array}{l}\text { Stratigraphic unit } \\
\text { (member of Ludlowrille } \\
\text { shale or Moscow shale, } \\
\text { as shown on fig. \&) }\end{array}$ & Description \\
\hline 15 & 3529 & Centerfield_..... & $\begin{array}{l}\text { Field exposure, just north } \\
\text { of eastwest trending } \\
\text { road, } 0.75 \text { mile E.N.E. } \\
\text { of Murder Creek ex- } \\
\text { posure of Centerfield. }\end{array}$ \\
\hline 16 & (52) & $\begin{array}{l}\text { Windom } \\
\text { (Upper). }\end{array}$ & $\begin{array}{l}\text { Bowen Brook, } 1000 \text { paces } \\
\text { south of bridge (up- } \\
\text { stream) } 1 \text { mile south of } \\
\text { Ray and northwest of } \\
\text { Alexander, Attica quád- } \\
\text { rangle, Genesee County. }\end{array}$ \\
\hline 17. & $\begin{array}{r}275 \mathrm{~A} \\
3503\end{array}$ & Centerfield _.... & $\begin{array}{l}\text { Exposure just north of D. } \\
\text { L. and W. railroad tracks } \\
\text { at milepost } 357,2.5 \text { miles } \\
\text { east of East Alexander, } \\
\text { Batavia quadrangle, } \\
\text { Genesee County. }\end{array}$ \\
\hline 18 & 1011 & $\begin{array}{l}\text { Wanakah } \\
\text { (Upper). }\end{array}$ & $\begin{array}{l}\text { Road cut, } 3.8 \text { miles north- } \\
\text { west of Pavilion, Batavia } \\
\text { quadrangle, G e n e s e e } \\
\text { County. (Shaly lower } \\
\text { beds } 5^{\prime} \text { below limestone). }\end{array}$ \\
\hline 18 & 3534 & $\begin{array}{l}\text { Wanakah } \\
\text { (Upper). }\end{array}$ & $\begin{array}{l}\text { Roadside exposure, } 1.5 \\
\text { miles southeast of East } \\
\text { Bethany, at the inter- } \\
\text { section of Stafford-Wy- } \\
\text { oming road and White } \\
\text { Creek. Just east of } \\
\text { locality } 1011 \text {. }\end{array}$ \\
\hline 19 & 3542 & Kashong & $\begin{array}{l}\text { Shale pit just west of inter- } \\
\text { section of White Creek } \\
\text { and route } 20,3 \text { miles east } \\
\text { of Bethany, Batavia } \\
\text { quadrangle, G en e s e e } \\
\text { County. }\end{array}$ \\
\hline 19 & (35) & Kashong & $\begin{array}{l}\text { White Creek; Kashong out- } \\
\text { crops in Creek at inter- } \\
\text { section with route } 20 \text {, } \\
\text { just east of collection } \\
3542 \text {. }\end{array}$ \\
\hline 20 & $\begin{array}{l}3539 \\
3541\end{array}$ & $\begin{array}{l}\text { Centerfield } \ldots . . . .- \\
\text { Ledyard }\end{array}$ & $\begin{array}{l}\text { White Creek; Centerfield } \\
\text { outcrops just south of D. } \\
\text { L. and W. Railroad and } \\
\text { west of Stafford-Wyo- } \\
\text { ming Road. Ledyard } \\
\text { outcrops just upstream. }\end{array}$ \\
\hline 21 & 3545 & $\begin{array}{l}\text { Wanakah } \\
\text { (Upper). }\end{array}$ & $\begin{array}{l}\text { East flowing creek at inter- } \\
\text { section with north-south } \\
\text { road, } 1.2 \text { miles west of } \\
\text { York, Caledonia quad- } \\
\text { rangle, L i v i n g s t o n } \\
\text { County. }\end{array}$ \\
\hline 22 & $\begin{array}{l}(39), \\
3500\end{array}$ & Kashong & $\begin{array}{l}\text { Dump of salt company, } 0.5 \\
\text { mile southeast of Greigs- } \\
\text { ville, Caledonia quad- } \\
\text { rangle, Livingston } \\
\text { County. }\end{array}$ \\
\hline
\end{tabular}

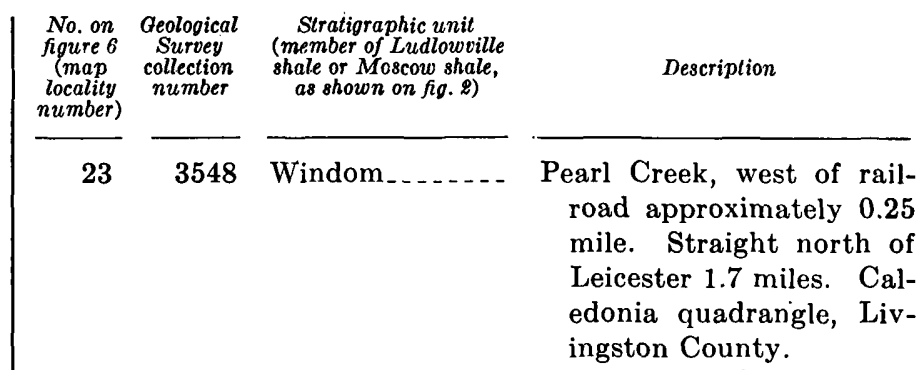

3501 Kashong. Little Beards Creek, 1 mile NNE of Leicester at farmhouse east of Leicester-Greigsville highway. Caledonia quadrangle, Livingston County.

253543 Kashong-....... Fall Brook, 1.5 miles SSW of Genesee, section just east of Genesee-Cuylerville road. Caledonia quadrangle, Livingston, County.

$26 \quad 3547$ Wanakah, Pleurodictyum

Jaycox Run, 2.3 miles north of Genesee, below falls, Caledonia quadrangle, Livingstor: County.

$27 \quad 3551 \quad$ Portland Point _ 3552 Kashong 3553 Windom

3555 Wanakah, Pleurodictyum zone.

3555a Deep Run

3556 Kashong

3586 Tichenor

3585 Windom........

(20) Wanakah (Upper).

3561 Centerfield ......
Menteth Creek, 5.5 miles south of Canandaigua, west side of Canandaigua Lake, Canandaigua quadrangle, Ontario County.

Deep Run, 1 mile north of Cottage City, east side Canandaigua Lake, Canandaigua quadrangle, Ontario County.

Creek at Green's Landing, 0.5 mile north of Deep Run.

Creek at Goodings Landing, 0.8 mile south of Cottage City, east side Canandaigua Lake, Canandaigua quadrangle, Ontario County.

Fall Brook, 3 miles ESE of Canandaigua, $\mathrm{C}$ a $\mathrm{n}$ a ndaigua quadrangle, $\mathrm{On}$ tario County.

Wilson Creek, 4 miles south of north end of Seneca Lake, on west side of lake, Geneva quadrangle, Ontario County.

Kashong Creek, 7.5 miles south of north end of Seneca Lake, west side of Lake, Geneva quadrangle, Ontario and Yates Counties. 


\begin{tabular}{|c|c|c|c|}
\hline $\begin{array}{l}\text { No. on } \\
\text { figure } 6 \\
\text { locaplity } \\
\text { number) }\end{array}$ & $\begin{array}{l}\text { Geological } \\
\text { Survey } \\
\text { collection } \\
\text { number }\end{array}$ & $\begin{array}{l}\text { Stratigraphic unit } \\
\text { (Member of Ludlowille } \\
\text { shale or Moscow shale, } \\
\text { as shown on fig. } 2 \text { ) }\end{array}$ & Description \\
\hline 33 & 3582 & King Ferry & $\begin{array}{l}\text { Big Hollow Creek, west } \\
\text { side of Cayuga Lake, } 4.5 \\
\text { miles NE of Ovid, Ovid } \\
\text { quadrangle, Seneca } \\
\text { County. }\end{array}$ \\
\hline 34 & 3581 & King Ferry _. . . - & $\begin{array}{l}\text { Sheldrake Creek, west side } \\
\text { of Cayuga Lake, } 3 \text { miles } \\
\text { NNE of Interlaken, } \\
\text { Genoa quadrangle, Sen- } \\
\text { eca County. }\end{array}$ \\
\hline 35 & 3593 & Centerfield..... & $\begin{array}{l}\text { Gould's Falls, creek just } \\
\text { north of Aurora, east side } \\
\text { Cayuga Lake, Auburn } \\
\text { quadrangle, Cayuga } \\
\text { County: }\end{array}$ \\
\hline 36 & $\begin{array}{l}3571 \\
3572\end{array}$ & $\begin{array}{l}\text { Centerfield...... } \\
\text { King Ferry }\end{array}$ & $\begin{array}{l}\text { Paines Creek, east side } \\
\text { Cayuga Lake, } 1 \text { mile } \\
\text { south of Aurora. Center- } \\
\text { field at Moonshine Falls, } \\
\text { King Ferry at Black } \\
\text { Rock. Genoa quadran- } \\
\text { gle, Cayuga County. }\end{array}$ \\
\hline 37 & 3575 & Windom_..... & $\begin{array}{l}\text { Clearview Creek, King } \\
\text { Ferry Landing, east side } \\
\text { Cayuga Lake, Genoa } \\
\text { quadrangle, Cayuga } \\
\text { County: }\end{array}$ \\
\hline 38 & 3579 & Windom & $\begin{array}{l}\text { Taughannock Falls, west } \\
\text { side Cayuga Lake, 2.5 } \\
\text { miles ESE of Trumans- } \\
\text { burg, Genoa quadran- } \\
\text { gle, Seneca County. }\end{array}$ \\
\hline 40 & 3569 & Windom & $\begin{array}{l}\text { Tributary of Salmon Creek, } \\
\text { northernmost of the two } \\
\text { west flowing tributaries } \\
\text { at Ludlowville, Genoa } \\
\text { quadrangle, Tompkins } \\
\text { County. }\end{array}$ \\
\hline 41 & 3562 & Windom $\ldots . . .$. & $\begin{array}{l}\text { Quarry of the Penn-Dixie } \\
\text { Portland Cement Com- } \\
\text { pany. 0.75 mile south- } \\
\text { west of South Lansing, } \\
\text { east side of Cayuga Lake, } \\
\text { Genoa quadrangle, } \\
\text { Tompkins County. }\end{array}$ \\
\hline 42 & $\begin{array}{l}3563 \\
3564 \\
3567\end{array}$ & $\begin{array}{l}\text { Portland Point. } \\
\text { King Ferry } \\
\text { Windom }\end{array}$ & $\begin{array}{l}\text { Portland Point or Nortons } \\
\text { Landing on Cayuga Lake, } \\
1.1 \text { miles southwest of } \\
\text { South Lansing, Genoa } \\
\text { quadrangle, Tompkins } \\
\text { County. }\end{array}$ \\
\hline 43 & 3570 & Windom & $\begin{array}{l}\text { Fillmore Glen, in Filimore } \\
\text { State Park, } 1 \text { mile south } \\
\text { of Moravia, Moravia } \\
\text { quadrangle, Cayuga } \\
\text { County. }\end{array}$ \\
\hline
\end{tabular}

GLOSSARY

The bryozoan terminology used in this paper is largely defined by $\mathrm{R}$. S. Bassler in the "Treatise on
Invertebrate Paleontology, part G, Bryozoa, p. G7 to G16." Additional terms and variant usages are defined below.

Amalgamate wall structure or appearance.-Term used for zooecial walls as seen in tangential section in which the zooecial boundaries are not visible and the positions of these boundaries are marked by relatively broad bands of apparently nonlaminated skeletal material. (Fig. 8 and pl. 11, fig. 3a.)

Atactotoechid wall structure.-See p. 32.

Axial Ratio.-Ratio between neanic diameter and total branch diameter.

Compound diaphragm.-Diaphragm formed by two or more simple diaphragms that are in contact most or all of the way across a zooecium. (Pl. 21, figs. 1-3.)

Cyst.-Small, hollow, subspherical body occurring within the zooecial cavity and composed of laminated material that is continuous with the laminae of supporting diaphragms or zooecial walls. (Pl. 10, fig. 4.)

Cystiphragm.-Skeletal partition extending from the zooecial wall into the zooecial cavity and recurved proximally to form a closed compartment by abutting against the zooecial wall or adjacent cystiphragm or diaphragm. Cystiphragms either partly or completely encircle the zooecial cavity to form a hollow ring and commonly occur in closely packed or overlapping series lining the zooecial cavities. Cystiphragms do not extend completely across the zooecial cavity. (Pl. 17, fig. 5.)

Cystoidal diaphragm.-A transverse structure formed by two diaphragms in contact only part way across the zooecial cavity to form a completely enclosed compartment between them. At least one of the partitions is a complete diaphragm. ( $\mathrm{Pl}$. 20, fig. 4b.)

Diaphragm.-Skeletal partition extending transversely across the zooecial tube or mesopore.

Diaphragm-wall unit.-The diaphragm and that part of the distally adjacent zooecial wall that are directly connected to form a continuous skeletal unit. (Fig. 8.)

Ephebic zone.-Part of individual and colony possessing most of the taxonomic structures. In the Trepostomata, the ephebic zone consists of the outer parts of zooecia and zoaria characterized by thickened zooecial walls, relatively abundant diaphragms, and mesopores and acanthopores, if present. Synonymous with mature region of authors. See figure 7 .

Hemiphragm.-Shelf-like platform in the ephebic part of zooecial tube, joined to the walls on the proximal side only and extending part way across the tube. The platform consists of laminae that are continuous with the laminae of the zooecial walls. (Fig. 22.) 

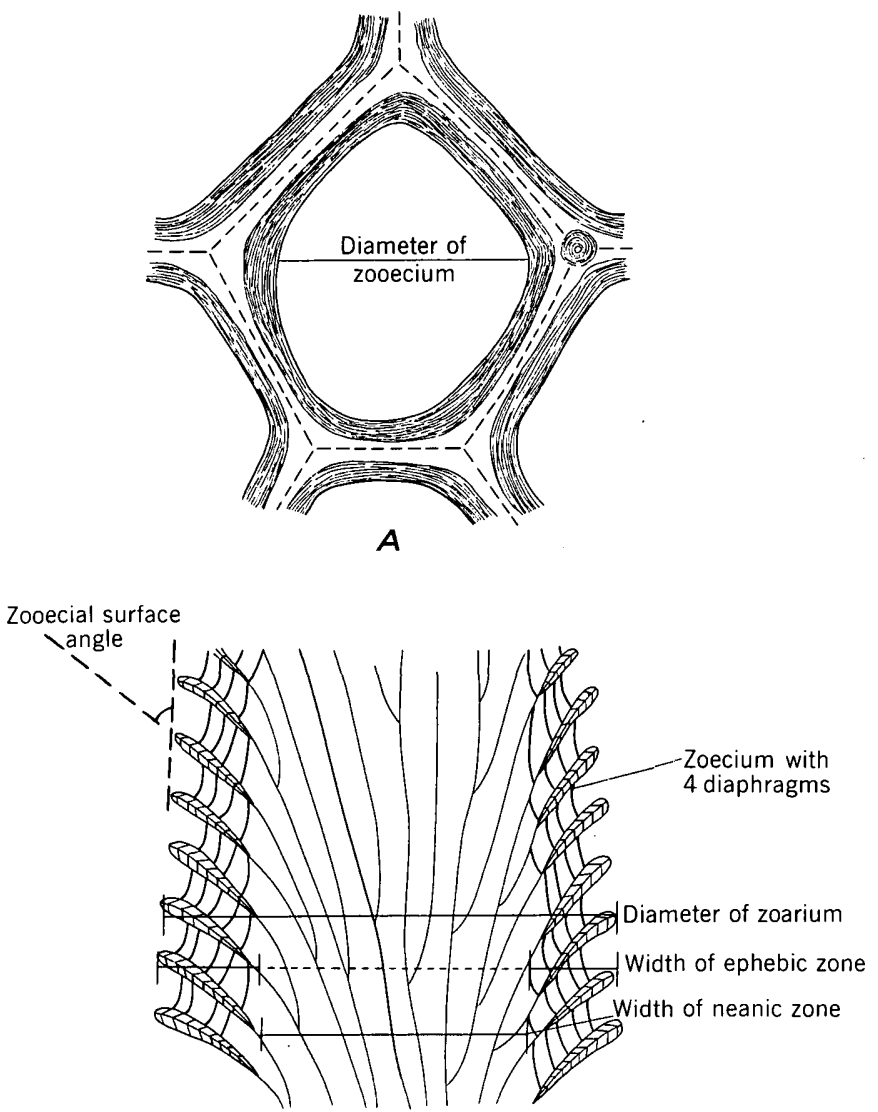

$\boldsymbol{B}$

Figure 7.-Diagrams illustrating standard measurements. $A$, tangential section of a single zooecium; $B$, longitudinal section of ramose zoarium.

Independent wall unit.-A segment of the zooecial wall that is not connected to the laminae of a diaphragm. (Fig. 8.)

Integrate wall structure or appearance.-Term used for zooecial walls as seen in tangential section in which zooecial boundaries appear as lines, either light or dark in shade. (Pl. 20, fig. 4a.)

Leioclemid wall structure.-See p. 30.

Leptotrypellid wall structure.-See p. 32.

Longitudinal section.-Section exposing the zooecia parallel to their length. In a ramose zoarium the plane of the section is in the center of the branch, parallel to branch length. In a massive or incrusting zoarium the plane of the section is perpendicular to the surface of the zoarium.

Measurements.-Numbers of zoaria included in the table of measurements for a species commonly are fewer than the total number of zoaria of that species available for study. In species in. which few zoaria were available, these discrepancies were caused by orientations of thin-sections that were oblique enough to affect or make impossible the measurements. Pre- cise orientation of thin-sections is especially difficult in irregularly massive or incrusting forms, and in zoaria that can not economically be freed from the matrix. In species in which many zoaria were available, it was considered not necessary to measure sections from all of the zoaria.

Megazooecium.-An enlarged zooecium developed in the monticules: (Pl. 12, fig. 7b.)

Mesopore.-Skeletal sac or tube, parallel to the zooecia but appreciably smaller in diameter and in most genera limited to the ephebic zone. Included diaphragms are generally more closely spaced than those in zooecia. (Pl. 2, figs. 2 and 5.)

Monticule.-Clusters of modified zooecia (generally megazooecia, mesopores, and acanthopores in different combinations) regularly spaced throughout a zoarium and appearing on the surface generally as small protuberances. (Pl. 11, fig. $3 \mathrm{~b} ;$ pl. 12, fig. 7b; pl. 14, fig. 2b.)

Mural lacuna.-Small equidimensional void in zooecial walls. (Pl. 11, fig. 3a.)

Mural spine.-Small laminated spine continuous with the laminae of the surfaces of zooecial walls and diaphragms and projecting into the zooecial cavity. (Pl. 8, figs. 4, 5a, and 6.)

Neanic zone.-Part of individual and colony too undeveloped to possess many taxonomic characters. In the Trepostomata the neanic zone consists of the basal or inner part of a zooecium and zoarium, characterized by thinness of zooecial walls and relative sparseness or absence of transverse structures. Synonymous with immature region or axial region of authors (fig. 7).

Overgrowth.-Conspecific secondary growth incrusting a zoarium and separated from the zoarium by a basal lamina. (Pl. 7, fig. 4a.)

Stereotoechid wall structure.-See p. 30 .

Tangential section.-Section parallel to and just under the surface of a zoarium. The section normally cuts the zooecia transversely.

Transverse section.-Section at right angles to the branch of a ramose zoarium.

Trachytoechid wall structure.-See p. 31 .

Zoarium.-The collective skeletal parts of a bryozoan colony.

Zone of curved laminae.-That part of the zooecial wall characterized by strong curving of the laminae as seen in longitudinal section. The laminae in the zone are continuous with the distal ends of the laminae of the diaphragms, or zooecial lining if present, and end at the zooecial boundary. (Pl. 10, fig. 1a.)

Zooecial bend.-Relatively sharp bend in the zooecium generally located either at the boundary between 
the neanic and ephebic zones or in the early ephebic zone. The concave side of the bend is always toward the proximal direction of the zoarium. (Pl. 6, fig. 8c.)

Zooecial boundary.-Narrow zone in which the wall laminae from adjacent zooecia merge or abut against each other. (Pl. 17, fig. 6a.)

Zooecial lining.-A zone in a zooecial wall consisting of the laminae that line a zooecium and trend parallel to the longitudinal direction of the zooecia for a considerable distance. The zone is continuous proximally with the laminae of the diaphragms and distally with the zone of curved laminae. (Fig. 12 and pl. 15, figs. 3a, 4.)

Zooecial surface angle.-The acute angle at which the zooecia intersect the surface of the zoarium. (Fig. 7.)

Zooecium.-Skeletal sac or tube that contained the soft parts (polypide) of the whole animal or zooid.

\section{MORPHOLOGY AND TAXONOMY}

The devising of a satisfactory classification of the trepostomatous Bryozoa is seriously handicapped by our complete ignorance of the living animal. The biologic significance of structures occurring in the order is speculative, consequently the taxonomic principles that can be applied to this large extinct group are limited. Most skeletal structures must be treated empirically and evaluated by indirect means. These indirect approaches provide the basis for many of the practical and usable features of the classification, but by themselves are likely to result in a high degree of artificiality.

The extent to which a natural classification of the Trepostomata can be established will depend on how much success students have in using biologic principles to substantiate and modify the largely artificial classification. The attainment of a natural phylogenetic classification throughout is an impossible goal; but a generally satisfactory classification, in part phylogenetic, and based on biologic principles whenever possible, should be attainable by careful study.

In establishing taxonomic criteria indirectly, the value of a character commonly is judged by its constancy in a number of forms. That is, a structure or characteristic that occurs throughout a group of obviously diverse forms is generally given a more important taxonomic role than another structure or characteristic that is seen in only a quarter of the forms. The reliability of a character is strengthened if it is associated with other characters that occur in the same grouping of specimens.

It happens commonly that there is a negative correlation between morphologic characters that are approximately equal in numbers of occurrence. Such negative correlations result in different groupings, depending on which character is given preference. It is. then necessary to accept one character as most important and downgrade the others in order to present a single taxonomic arrangement. Purely subjective suppression of certain taxonomic characters is certainly not a sound basis for a natural classification.

If established biologic principles can be applied to problems of taxonomic evaluation, many preferential decisions can be made with the hope of approximating the natural grouping. In the Trepostomata, the study of complete zoaria contributes to the understanding of ontogeny, polymorphism, and mode of colonial growth. Distributional studies in time and space furnish data for the evaluation of more realistic species concepts. These distributional studies are based on the essentially nondimensional collections that provide data on morphologic variation in inferred population samples, and superimposed collections from single localities that give relative time relationships. Geographic distribution and paleoecologic interpretations complete the distributional data. These and other biologic principles are essential factors in inferring evolutionary trends and patterns and developing a more nearly natural, phylogenetic classification.

\section{EARLY HISTORY OF THE STUDY OF THE ORDER TREPOSTOMATA}

Study of the Trepostomata is separable into two periods based on techniques and approach used in morphologic and taxonomic investigations. Students in the earlier period mainly observed growth habits of the zoaria and details of external appearance. The second period is marked by the additional study of internal features of the zoaria by means of thin sections, and the increased importance of the zooecia in the classification. The more recent approach has shown the earlier work to be ineffectual and misleading in both biologic and stratigraphic applications. Growth habits of the zoaria are now considered of minor taxonomic importance in the Trepostomata, for zoaria that are similar in growth habit and external appearance are known to differ conspicuously in microscopic internal structure. The current classification of the order is based on internal characters and external homeomorphy is generally an important factor in the study of Trepostomata.

The Trepostomes have "stony" and massive zoaria rather than the "mosslike" skeletons that are characteristic of many living bryozoans. Consequently, trepostomes were relegated to the coral group when the Bryozoa was first recognized in 1830 by Thompson (Polyzoa) and in 1831 by Ehrenberg (Bryozoa). In the latter half of the nineteenth century an active 
controversy aros concerning the zoological affinities of the trepostome group. The arguments on both sides were confused because of poorly defined concepts of taxonomic groups called the "favositids," "monticuliporoids," "stenoporoids," "chaetetids," and "trepostomes." At one time or another, all of these groups contained both bryozoans and corals in varying proportions depending on the prejudices of individual authors. When thin-section studies were first introduced, many structures were misinterpreted. Certain genera were declared to be "truly" corals or bryozoans on erroneous grounds. These genera were then used as standards for comparison with related genera, and all were designated either corals or bryozoans.

In 1876 Nicholson (p. 85-95, pl. 5) published what are probably the first illustrations of thin sections of Bryozoa. Nicholson followed this paper by a series of outstanding publications that established the need for thin sections, and recognized the major internal structures subsequently used in the modern classification of the trepostomes, or monticuliporoids as they were then known. Nicholson recognized the minor taxonomic value of zoarial growth habit $(1879$, p. 273) and the occurrence of apparently dimorphic individuals in the zoaria $(1879$, p. 276). He correctly described the structure of acanthopores (1879, p. 278) and distinguished inner thin-walled zones and outer thick-walled zones in the zoaria (1881, p. 31).

Nicholson was probably the leading advocate of the view that the affinities of the monticuliporoids were with the corals rather than with the bryozoans. One of his main arguments favoring coral affinities was the belief that the bryozoan genus Stenopora Lonsdale had mural pores and was an undoubted favositid coral (1879, p. 173). As comparisons between the monticuliporoids and Stenopora were convincing and valid, he considered all of the monticuliporoids to be tabulate corals. However, his discussion indicates he experienced some difficulty in interpreting the wall structures in thin sections. Waagen and Wentzel (1886, p. 886) pointed out that Nicholson was working with imperfect material in which the actual walls had been removed by solution, leaving internal molds of the zooecia. Thus, the presence of mural pores actually could not have been determined. Nicholson subsequently (1889, p. $350)$ accepted the interpretation of Waagen and Wentzel and placed Stenopora with the monticuliporoids, but remained uncertain as to the affinities of the general group.

Waagen and Wentzel (1886, p. 855) and G. R. Vine (1884, p. 182) agreed with Nicholson on the coralline affinities of monticuliperoids. Waagen and Wentzel attempted to develop a line of argument in favor of corals based on the mode of propagation of the individuals in colonies. Their description of gemmation in monticuliporoid zoaria assumed that mesopores and acanthopores are not polymorphic individuals but merely young zooecia in the initial stages of formation. This concept has not been subsequently substantiated.

The first attempt to assign the general trepostome group to the bryozoans probably was made by Rominger of Michigan (1866, p. 1-3). He compared some of the genera now included in the Trepostomata with the genus Heteropora, a post-Paleozoic form that he considered transitional between Paleozoic trepostomes and undoubted bryozoans. Heteropora was mentioned throughout the controversy by other authors also, procoral advocates either denying morphologic similarities with the trepostomes or arguing that Heteropora was not a bryozoan.

In 1873 Dr. Gustav Lindstrom published a paper on the affinities of the Anthozoa Tabulata in the Proceedings of the Swedish Academy of Science, later translated (1876, p. 1-17), in which he cited Rominger's work and placed a number of the known genera of trepostomes in the Bryozoa. Lindstrom was one of the first to use astogeny as an approach toward answering the question. He claimed that as a colony developed from the first few cells it passed morphologically from one "genus" to the next, as genera were then defined. Further, he claimed he could trace mature colonies of trepostomes back to initial stages that belonged to genera of undoubted bryozoans. Unfortunately, no illustrations were published and stages of development were defined by comparing them with poorly understood genera. Lindstrom's work is difficult to evaluate and served only to heighten the argument. About the same time Dollfus (1875, p. 681-683) and Zittel (1880, p. 575-641) placed the family Chaetetidae, then containing most of the trepostomes, in the Bryozoa.

In $1882 \mathrm{E}$. O. Ulrich began a series of publications that produced our present classification of the Paleozoic Bryozoa. Using the techniques and approach outlined by Nicholson, Ulrich established the suborder Trepostomata (Ulrich, 1882, p. 151) and began the first comprehensive study of the group. Ulrich agreed with Nicholson on the interpretation of many structural features but believed the group to be Bryozoa, comparing them with post-Paleozoic Cyclostomata, which were accepted bryozoans.

In $1902 \mathrm{E}$. R. Cumings began a series of definitive papers on early Paleozoic Bryozoa, presenting factual evidence that helps clarify many of the perplexing problems relating to the Trepostomata. Cumings made 
a detailed study of the initial stages in the development of zoaria belonging to the fenestellids and the monticuliporoids. He showed that the Cryptostomata and Trepostomata started zoarial growth in the same manner and that the development of bryozoan zoaria was radically different from that of typical tabulate corals (1912, p. 365). Cuming's observations have since been accepted as critical evidence bearing on the zoological affinities of the trepostomes and, added to the mass of morphologic comparisons, ended the controversy about the zoological relationships of the Trepostomata.

\section{WALL STRUCTURE AND TAXONOMY PREVIOUS WORK}

The early descriptions of zooecial wall structure by Nicholson were based on tangential views and were concerned largely with the amalgamate or discrete appearance between adjacent tubes, depending upon the presence or absence of a dark line marking the tube boundaries. The dark line was interpreted as the primordial wall (Nicholson, 1881, p. 37).

Nicholson's methods and his reliance on the tangential sections in interpretations of wall structure were perpetuated by Ulrich and later by Bassler. In 1890 Ulrich published a monograph on the Paleozoic Bryozoa that is probably the most important single work on the trepostomes. The classification proposed is the basis for the one used today (Bassler, 1953, p. G91-G119). Wall structure of trepostomes in general was described. The line dividing adjacent zooecia was termed the "primitive wall" (Ulrich, 1890, p. 310) and the material thickening the zooecial walls in the ephebic zones was called a "secondary deposit" (Ulrich, 1890, p. 307).

Ulrich and Bassler published a revision of the Paleozoic Trepostomata in 1904. Two "divisions" of the trepostomes were recognized on the basis of zooecial wall structure as seen in tangential thin sections.

The classificatory value of the structure of the walls separating neighboring zooids, especially the degree in which the calcareous investment of adjoining zooids is either amalgamated or maintains for each its integrity, continues to impress us more and more favorably (Ulrich and Bassler, 1904, p. 15).

Accordingly, they divided the Trepostomata into the Amalgamata, including four families, and the Integrata, including three families.

The families currently recognized (Bassler, 1953) remain essentially unchanged since the 1904 revision. In 1911, Bassler published a paper on the early Paleozoic Bryozor of the Baltic Provinces that best ex- presses the Ulrich-Bassler classification of the trepostomes. Wall structure was considered to provide fundamental criteria for family groupings (Bassler, oral communication 1952). The following quotations taken from either the 1904 or 1911a papers summarize the published information on the wall structures in their classification.

\section{DIVISION I. AMALGAMATA, 1904}

"Trepostomata in which the boundaries of adjacent" zooecia are obscured by the more or less complete amalgamation of their walls" (Ulrich and Bassler, 1904, p. 15).

Family MONTICULIPORIDAE Nicholson (Emend. Ulrich)

The wall structure of the family is best expressed by a description of the type genus, as follows:

"The peculiar granulose walls, the vary slight development or total absence of the laminated secondary deposit * * *" (Ulrich and Bassler, 1904, p. 15).

\section{Family HETEROTRYPIDAE Ulrich, 1890}

"As seen in tangential sections of well preserved specimens, the wall separating adjacent zooids consists (1) of a moderately wide, light-colored, transversely dotted or lined, central band, which represents the amalgamated original walls, and (2) bordering it on each side, a concentrically laminated, secondary deposit" (Ulrich and Bassler, 1904, p. 23).

Family CONSTELLARIIDAE Ulrich in Zittel, 1896

"The most obvious characteristic of the family is the usually stellate shape of the maculae. More important features are the small, hollow spines or granules which occur in place of true acanthopores, and a somewhat granular wall structure occurring in the more mature portion of the zoarium" (Bassler, 1911a, p. 218).

\section{Family. BATOSTOMELLIDAE Ulrich in Miller, 1889}

"In this family the amalgamate nature of the zooecial walls is most marked, in fact so much so that adjoining walls usually appear as completely fused together" (Bassler, 1911a, p. 240).

\section{DIVISION II. INTEGRATA 1904}

"Trepostomata in which the boundaries of adjacent zooecia are sharply defined by a black divisional line" (Ulrich and Bassler, 1904, p. 40).

"This line in all probability represents the fossilized remains of animal matter which filled this space during the life of the organism. Occasionally, this narrow, intervening area is occupied by a light-colored tissue, and in this case the outer boundaries of the walls of each zooecium can be seen." (Bassler, 1911a, p. 177).

\section{Family AMPLEXOPORIDAE Ulrich in Miller, 1889}

"The simplest types of Integrata are included in this family, which, because of this simplicity as well as the practical absence of mesopores, shows the duplex character of the walls most distinctly" (Bassler, 1911a, p. 265).

\section{Family HALLOPORIDAE Bassler, 1911 (emend. Calloporidae Ulrich, 1890)}

"The family includes those integrate trepostomatous bryozoans in which the zooecial tubes are thin-walled and attain 
their full size slowly, but chiefly in which acanthopores are absent" (Bassler, 1911a, p. 325).

Family 'TREMATOPORIDAE Ulrich in Miller, 1889

"Walls thickened in the mature region, with a distinct divisional line where the zooecia are in contact. As a rule the Trematoporidae have a general looseness and slight obscurity of structure quite unlike that of any other family. For example, the walls are not as clear and distinct as in the Amplexoporidae or Halloporidae, the acanthopores have a less definite, clear cut structure, and the walls are often undulating" (Bassler, 1911a, p. 267).

In 1915 Cumings and Galloway published a significant paper on the morphology of the trepostomes. They found a species of the genus Heterotrypa (placed in the Amalgamata by Ulrich and Bassler) that displayed both an amalgamate and integrate appearance in tangential sections. This observation led them to study wall structure in longitudinal views using thinner sections and higher magnifications than had been previously employed. Cumings and Galloway (1915, p. 360) found that wherever wall laminae are sharply bent, the deposit appears darker. If the laminae intersect the boundaries at low angles they are most sharply bent at the zooecial boundaries. Cumings and Galloway considered the sharp bending of the laminae to be the origin of the dark "primary" wall exhibited in tangential sections and used to define the Integrata of Ulrich and Bassler. Also, (Cumings and Galloway, 1915 , p. 365)

the presence or absence of a dark median line in the wall depends to a large extent on the steepness of pitch of the laminae, which in turn depends on whether the growing edge of the wall is thin and sharp or blunt and smoothly rounded.

"Pitch of the laminae" was found to be variable within a species and even within a specimen $(1915$, p. 359$)$. In evaluating the taxonomic use of the amalgamate and integrate appearance they state-

If the differences above described are due primarily to the steepness of pitch of the wall laminae, it is likely that the classificatory value of this phase of wall structure in the Trepostomata is also of subordinate rank (1915, p. 361).

Cumings and Galloway (1915, p. 361) interpreted the laminae lining the zooecial walls and extending into the diaphragms and cystiphragms to be secondary in origin.

The secondary deposits we have designated the cingulum, because in tangential sections *** they give the appearance of a well defined ring or zone of deposits adjacent to the zooecial cavity.

G. W. Lee (1912, p. 145) also found difficulty with the amalgamate-integrate concept. He wrote:

In the British fauna, so far as examined, a black line is occasionally exhibited in forms which are otherwise referable to the division Amalgamata. Its adoption as a classificatory character in the case of the materials considered here would lead to an inconsistent grouping of the species, and is therefore deferred pending further investigation.

Helen Duncan $(1939$, p. 186) had difficulty in placing the Traverse genera in the Ulrich-Bassler classification and proposed the family Atactotoechidae to include genera displaying both amalgamate and integrate structure. In discussing the genus Atactotoechus, Duncan comments:

The fact that some species of Atactotoechus have integrate and others amalgamate walls does not seem to be an adequate reason for placing in different families forms having other homogeneous structural characters.

\section{WALL STRUCTURE AND TAXONOMY IN THE HAMILTON TREPOSTOMATA}

A study of the well-preserved Trepostomata from the Hamilton group of New York indicates that some genera cannot be placed in suborder and family categories as presently defined in the literature. Several species of both Atactotoechus and Leptotrypella show both amalgamate and integrate wall structure in tangential sections, the same condition also observed by Duncan in Traverse species, and by Cumings and Galloway, and Lee in trepostomes of other systems. Such variation within a species, and even within a zoarium, conflicts with the degree of constancy expected for usable subordinal characters.

The writer also had difficulty applying recognized criteria for families. Species of Leptotrypella in the Hamilton group do not have a "transversely dotted or lined, central band, which represents the amalgamated original walls" described as characteristic of the Heterotrypidae by Ulrich and Bassler. Rather, the "central band" in well preserved specimens of Leptotrypella appears to be structureless and hyaline in all but a few tangential sections. A few specimens exhibit uniformly spaced mural lacunae or rare clusters of irregularly spaced mural lacunae, that can be considered small "dots" but they are unknown in some species of Leptotrypella and are interpreted as a species character at best in the genus.

A still more difficult problem is posed by the genera now referred to the family Stenoporidae (Bassler, 1953 , p. G101). No essential differences were seen between tangential thin sections of Hamilton stenoporid genera and sections of the heterotrypid genus Leptotrypella lacking mural lacunae. All the New York species of Stereotoechus, Dyoidophragma, Leioclema, and Trachytoechus have the hyaline "central band" typical of the amalgamate wall, surrounded by a laminated zone that appears to line the zooecia. The relative thicknesses of the "central band" and the laminated zone are fairly constant for Stereotoechus and Dyoidophragma but relative widths of these zones 
have not been considered in the definition of families and generally do not appear constant enough for such application.

Because of these difficulties with the supergeneric classification, a detailed study of the skeletal morphology of the Hamilton Trepostomata was made. The writer resorted to the approach first used by Cumings and Galloway, and studied longitudinal sections as well as the tangential sections, both under high magnifications, better to understand zooecial wall structure in three dimensions.

As a general rule, the laminated material of all diaphragms continues without interruption into the zooecial walls (fig. 8). The laminae of the diaphragms normally increase in number as they join the walls so a single diaphragm is continuous with a considerably thicker wall deposit. In the wall, the laminae may run parallel to the longitudinal direction of the zooecium for a considerable distance to form a lining to the zooecial tube; or, the laminae may extend directly into the wall at an angle to the longitudinal direction of the zooecium. Regardless of the inclination of the laminae as they enter the wall, all, or a part of the laminated material can be traced to its termination at the zooecial boundary in well preserved specimens from the Hamilton group. A diaphragm plus the distally connected wall deposit are interpreted to form a unit of skeletal growth that was deposited at approximately the same time and is here termed a diaphragm-wall unit (fig. 8).

The exact boundaries of a diaphragm-wall unit are difficult to define in many species and in poorly preserved material. It is commonly evident, however, that short, disconnected lengths of a zooecial wall are not continuous with diaphragm laminae. These independent wall units (that is, not connected to diaphragms) may completely encircle the zooecium (shaded area in fig. 8); or they may pinch out between two converging diaphragm-wall units (coarsely laminated area in fig. 8) so that no independent wall unit can be distinguished in a corresponding position in the opposite wall of the zooecium. In these independent wall units, structure and inclination of the laminae are exactly the same as in the diaphragm-wall units and are interpreted to be essentially similar in origin to the wall portions of the diaphragm-wall units. One type of wall unit followed another in apparently no particular order as the zooecium grew distally. Distally placed units are considered progressively younger. Thus, active addition of skeletal material occurred only in the outermost wall unit at any one time.

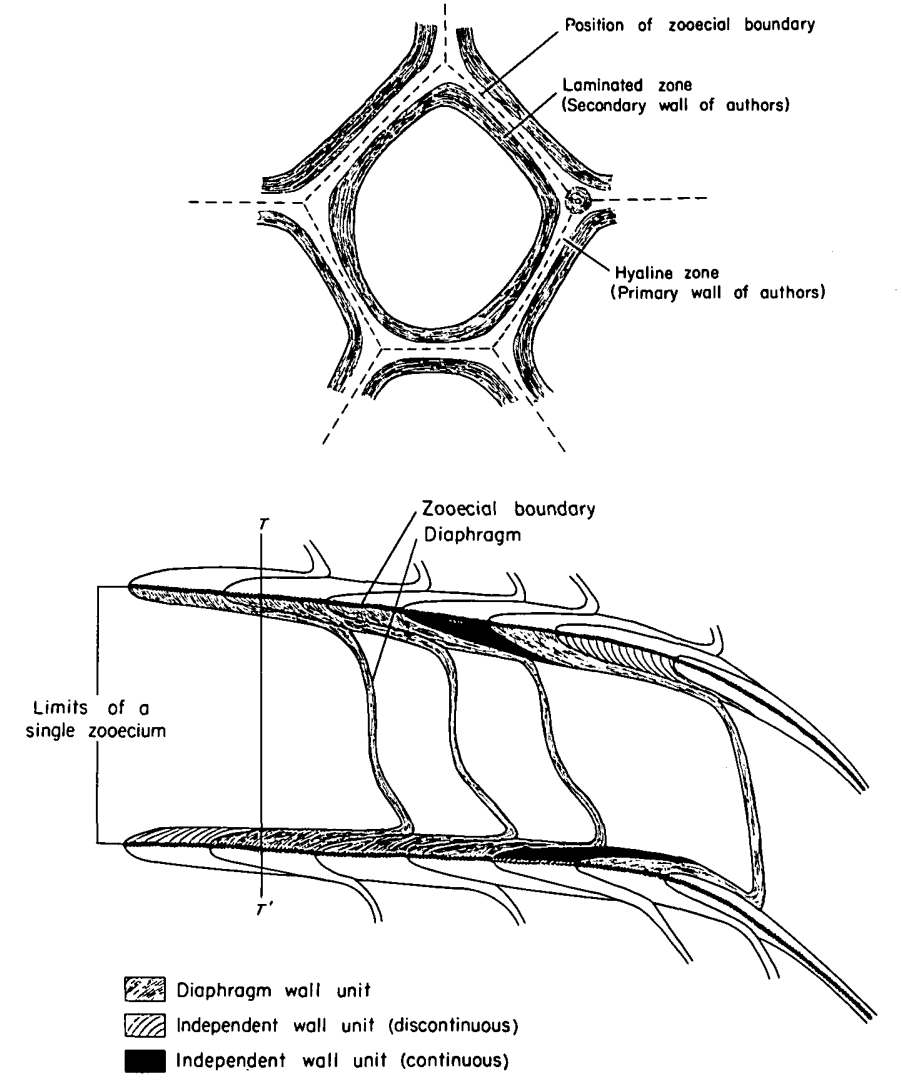

Figure 8.-Diagrammatic tangential and longitudinal sections of a zooecium of a generulized trepostome bryozoan lllustrating the laminated structure of the skeleton. Line $T-T^{\prime}$ in the longitudinal view indicates the position of the trace of the plane of the tangential section. The position of the zooecial boundary in the tangential view is indicated by a dashed line because the houndary is not seen in this view of an amalgamate wall. The small circular laminated structure is an acanthopore. In the longitudinal view the outlined walls outside the inferred limits of the single zooecium are thought to be deposited by the two adjacent polypides.

The above interpretation of the structural relationships of the wall laminae indicates that no part of the zooecial wall can be considered to be of secondary origin in the Hamilton trepostomes. However, some specimens of Leptotrypella (pl. 6, fig. 7; pl. 8, figs. $4,5 \mathrm{~b}$, and 7 ) have zooecial linings that suggest secondary deposition. The laminae run parallel to the longitudinal direction of the zooecia for a considerable distance, commonly passing under two or three distally located diaphragms before finally bending outward to the zooecial boundary. The apparent distinctness of this zooecial lining is emphasized by the light color of the laminated deposit of the lining relative to the darker appearing deposit of the zone of curved laminae. However, Cumings and Galloway observed that the laminae become distinctly darker in appearance in thin section if they are curved. This curving of laminae might be the explanation of the darkening, as the laminae in the lining are straight and generally much lighter in shade than the distal 
extension of the same laminae as they bend toward the zooecial boundary. The important structural feature, however, is the continuity of the laminae from the light-colored lining into the darker curved part of the wall. In the specimens referred to in plates 6 and 8 above, only a small proportion of the laminae of the zooecial lining can be traced to the zooecial boundary. Continuity of laminae from diaphragm to zooecial boundary is more generally seen as shown in text figure 8, however, and is characteristic of all the Hamilton genera except Leptotrypella.

Study of the longitudinal views of zooecial walls such as that carried on by Cumings and Galloway (1915, p. 359) suggests that a polypide contributes the inner half (relative to the polypide) of the deposits in the double or compound wall surrounding the polypide. The extent of the deposits formed by one polypide is marked by the zooecial boundary (text fig. 8). Adjacent polypides surrounding a zooecium contribute the material for the other half of the compound wall. The wall building from both sides of a zooecial boundary by adjacent polypides results in onehalf of the compound wall being the mirror image of the other, when viewed in longitudinal or tangential thin sections. Laminae commonly can be seen to end abruptly in the zooecial boundary region and abut against the ends of laminae from adjacent zooecia (see Cumings and Galloway, 1915, pl. 14, 15) and (pl. 14, fig. 1d and pl. 17, fig. 6a) throughout the Trepostomata. Zooecial boundaries in general, however display a wide range of appearances that can be constant for a genus or that can vary considerably within a species or specimen. Some species and genera show little or no evidence of discontinuity at the boundaries as seen in longitudinal sections (pl. 10, fig. 1a). The laminae from adjacent zooecia in such specimens appear to merge without interruption at the position of the boundary. Little notice has been taken of the longitudinal aspect of zooecial boundaries in previous descriptions. Future observations may prove that this feature is a useful taxonomic character in some groups.

The laminated zones seen lining the zooecia in tangential sections and interpreted as being secondary by Nicholson, Ulrich and Bassler, and Cumings and Galloway must be correlated with primary structures if observations and interpretations based on the longitudinal views of Hamilton trepostomes are correct. The fundamental reason for the contrasting laminated appearance of the zooecial linings and the hyaline or dotted "central bands" of the amalgamate wall was first pointed out to the author by Helen Duncan. The material of the zoaria, at least in the ephebic zone, is laminated throughout. If the plane of a thin section cuts the skeletal material at right angles to the plane of the laminae, the laminae will obviously be seen in transverse view, one lamina upon the other. If the plane of a thin section cuts the skeletal material parallel to the plane of the laminae, the plane of the thin section will lie within a very few laminae, the laminated structure will not be apparent, and a hyaline or granular appearance will result, depending on the texture of the laminated material. Considering the orientation of the plane of the tangential section while looking at a longitudinal thin section, it is readily seen that in the usual amalgamate walls (text figs. $9-12)$ the curving laminae intersect the plane of the tangential section at varying angles. Near the margin of the wall adjacent to the zooecial chamber, the laminae are approximately at right angles to the tangential section. Therefore, these laminae are cut transversely and appear as laminated areas in the tangential section. As the laminae approach the zooecial boundaries, however, they gradually curve through an arc of 90 degrees. Finally the laminae are parallel to the plane of the tangential section, and that area of the tangential slide appears to be nonlaminated and hyaline. The hyaline area, which extends for varying distances on either side of the zooecial boundary, is the "central primary band" of previous authors. The "secondary, laminated, zooecial linings" of previous authors are merely those areas where the wall laminations are cut at high angles by the tangential section.

In most integrate zooecial walls, the laminae, as seen in longitudinal section (fig. 13) never curve enough to become parallel to the plane of the tangential section over an appreciable distance. Thus, a tangential section intersects nearly all the wall laminae at high angles resulting in the laminated nature of the wall material being displayed throughout the thickness of the wall. At the narrow zooecial boundary zone the laminae terminate or bend sharply and are parallel to the plane of the tangential section only at the line of junction of zooecia. The zooecial boundary thus appears in tangential section as a line or narrow light shaded hyaline zone differentiated from the typical laminated structure on either side of the boundary.

Laminated structure must inevitably appear in tangential sections wherever the laminations are at a high angle or perpendicular to the planes of the sections. The laminated structure of the acanthopores as seen in tangential sections is attributable also to perpendicular orientation of the deposits to the section. The laminae surrounding the central tubes of the acan- 
thopores were deposited as a series of superimposed cones pointing distally and making spinelike projections on the surfaces of the zoaria. The laminae are approximately perpendicular to the plane of the tangential section within the cones. If the cones are truncated by a tangential section the acanthopore appears as a concentrically laminated structure.

Mural spines are characteristic of many species of Leptotrypella, and of two species of Atactotoechus, in the Hamilton group. Spines of similar size and position in zooecia have been reported in other Paleozoic and post-Paleozoic species. The spines in Hamilton species are projections of the laminated material either of the zooecial walls or of diaphragms. The spines are laminated throughout, the laminae paralleling the surfaces of the spines as the spines were secreted. Sections cutting spines longitudinally show a series of superimposed cones which extend their laminae into the wall laminae without interruption. Sections cutting the spines transversely show a concentrically laminated structure.

Many spines appear to have a nonlaminated core (pl. 11, fig. 5a) of clear calcite. The nonlaminated appearance is again due to the approximate parallelism of laminae and the plane of the thin section. Minor adjustments of the focus of a microscope at higher magnifications readily demonstrate the completely laminated structure of the spines.

The spines apparently developed as the wall laminae formed. The base of a spine lying distal to another spine in the same zooecium is connected to wall laminae that partly surround or imbed the older spine (pl. 8; fig. 4). Thus, a spine developed in the early ephebic zone can be partly buried by subsequent deposits. There is some evidence that each spine originated at an approximately constant distance from the advancing aperture in the genus Leptotrypella.

The function of spinose structures lining the skeleton and pointed toward the soft polypide is a matter for speculation. From the study of recent bryozoans, it can be assumed that the polypide need not fill the entire chamber of the zooecium, so such a projection would not necessarily have interfered with the soft parts. The spines might possibly have been attachment supports for muscles or ligaments, but such speculation is premature.

The spines are not considered comparable with those discussed by Elias (1956 reference to spines not made in abstract but included in talk) as nonbryozoan symbionts or penetrants. The direct connection of the laminae of the spines with those of the zooecial walls or diaphragms is convincing evidence that the spines were produced by the bryozoans.
Some of the Hamilton species of Leptotrypella and Trachytoechus display minute pores in tangential views that are here termed mural lacunae (pl. 5, fig. $3 \mathrm{a} ;$ pl. 11, fig. 3a). The nature of at least some of these pores is clarified by study of longitudinal sections. In many of the species involved, the zooecial boundary is a relatively wide serrated zone, the laminae from adjacent zooecia either overlapping or falling short of the actual center line (pl. 6, fig. 5, 8a). Overlaps from one side are matched by shortened laminae from the other. Failure of groups of laminae from opposite sides of the boundary to make contact with each other results in minute equidimensional voids. The voids or lacunae are the minute pores of tangential sections.

In the Hamilton material the mural lacunae are filled with clear calcite and their nature is evident. In the material from the Traverse of Michigan, however, the voids are generally filled with opaque minerals such as pyrite and there is no indication of the true nature of the structures. Thus, zooecial walls with opaque lacunae were described as having a coarsely granular appearance superimposed upon a laminated wall structure.

\section{TENTATIVE GROUPINGS OF GENERA FROM HAMILTON} AND TRA VERSE GROUPS

As indicated in the foregoing discussion of wall structure, Middle Devonian genera do not readily fit into the present classification of the Trepostomata. The suborders Amalgamata and Integrata are based on the appearance of the zooecial walls in tangential sections. In some species integrate and amalgamate appearances can and do occur in a single zoarium. In other forms, one aspect is constant for a species or a genus. Integrate or amalgamate appearance alone is not considered a usable criterion for differentiating suborders. The tangential views of Middle Devonian genera that have been assigned to the families Heterotrypidae and Stenoporidae do not show consistent differences in microstructure. Many characters are so similar in Hamilton genera that the assignment of genera to one family or the other is largely arbitrary. An attempt was made by the author to study thin sections of at least the type species of most Paleozoic genera of the Trepostomata in the hope of establishing a more generally usable family classification from a reasonably complete representation of the order. Primary types of most type species of the genera are available but the original sections are too thick to show wall structure in adequate detail. Until a thorough study can be made, the Devonian genera known from the Traverse group of Michigan and the Hamilton group of New York are here segregated into 
tentative supergeneric categories that are not formally named.

Study of longitudinal and tangential sections together indicates that the Middle Devonian genera can be sorted into two groups that may prove to be of subordinal rank. In the larger groups the genera are characterized by laminae that bend in a sweeping curve as they approach the zooecial boundary and intersect the boundary at right angles (text figs. 9-12). The walls commonly appear amalgamate in tangential view, but there are many exceptions, especially in forms having a very narrow zone of curved laminae resulting in a narrowly amalgamate to integrate appearance (pl. 6 , figs. $6,8 \mathrm{~b}$; pl. 13 , figs. $5 \mathrm{~b}, 5 \mathrm{c}$ ). The width of the zone may vary sporadically or may be a constant specific character as in Leptotrypella mesostena mesostena (p. 55).

The smaller of the two main groups of Middle Devonian trepostomes is characterized by wall laminae that remain fairly straight as they approach the zooecial boundary (fig. 13). As a result, the laminations are oriented at an angle to the zooecial boundary and intersect the boundary at less than 90 degrees. This smaller group of Devonian Trepostomata commonly appears to be integrate in tangential view, but many specimens range from integrate to at least narrowly amalgamate (pl. 20, fig. 1c). Amalgamate appearance in walls formed by the fairly straight laminations results when the laminae intersect the zooecial boundaries at comparatively high angles, so that the plane of the laminae nearly coincides with the plane of the tangential section. There seems to be a critical angle between the planes of the laminae and tangential sections beyond which an amalgamate appearance is produced.

Within the two main groupings described above, five types of wall structure are distinguished in the material studied: four of the types fall into the first grouping characterized by wall laminae that are strongly curved near the zooecial boundaries and the fifth type is characterized by wall laminae that remain relatively straight as they approach the zooecial boundaries. Taxonomic characters other than wall structure were not considered in the initial grouping of the genera-however, there is some correlation between wall structure and other characters as will be noted in the discussion of the individual groups. Use of as many characters as possible is desirable but at this exploratory stage, in which relatively few of the described trepostome genera have been critically studied, overall evaluation of possible family characters is impossible. Each type of wall structure dif-

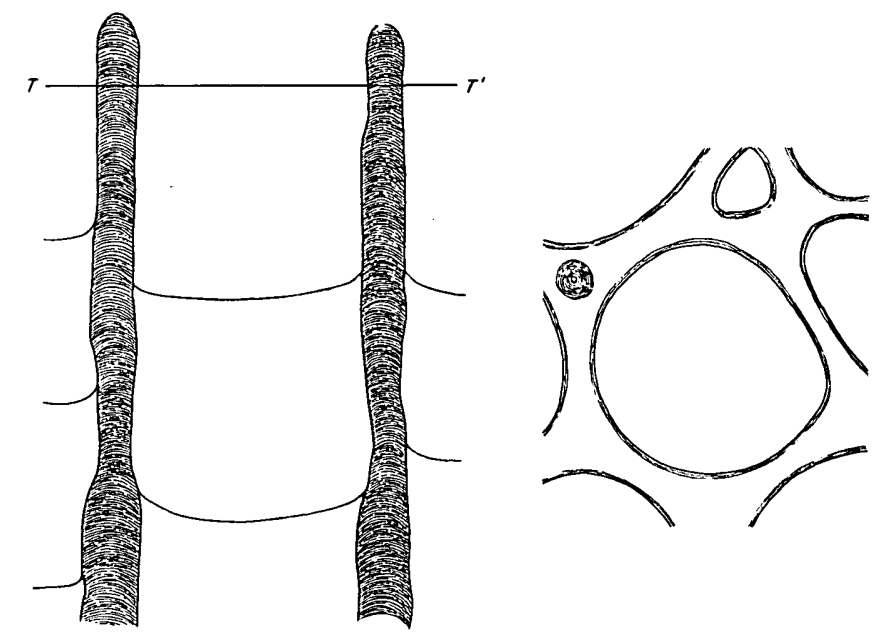

Figure 9.-Diagrammatic longitudinal and tangential sections of a single zooecium of Stereotoechus Duncan. Line $T-T^{\prime}$ on the longitudinal view of the zooecium indicates the position of the trace of the plane of the tangential section. In the tangential view the small circular laminated structure is an acanthopore, and the subtriangular tube is a mesopore.

ferentiated is named for a genus typically displaying that structure.

\section{STEREOTOECHID WAIL STRUCTURE}

Wall structure in this group is typified by the genus Stereotoechus Duncan. As seen in longitudinal section (fig. 9), the zooecial wall laminae are short, broadly curved throughout their length, and largely transverse to the length of the zooecia. The zooecial boundaries commonly are not discernible in either longitudinal or tangential sections. The laminae from adjacent zooecia apparently merge without break or abut irregularly throughout the width of the wall without forming a well-defined boundary. In tangential view, the walls are amalgamate; the nonlaminated areas are characteristically broad, and the laminated areas lining the zooecia are correspondingly narrow. Diaphragms are uniformly thin in the genera included in this group and are difficult to trace into the zooecial walls.

In addition to Stereotoechus, the group includes Dyoidophragma Duncan, Eostenpora Duncan, and Calacanthopora Dincan.

\section{LEIOCLEMID WALL STRUCTURE}

The genus Leioclema Ulrich demonstrates another wall structure. As seen in longitudinal section (fig. $10)$, the mesopore wall laminae are separated into well defined diaphragm-wall units that ordinarily can be traced across 2 or 3 adjacent mesopores. Independent wall units occur sporadically between the diaphragmwall units. Unlike the stereotoechid wall structure, the individual laminae trend approximately parallel to the longitudinal directions of the zooecia and 

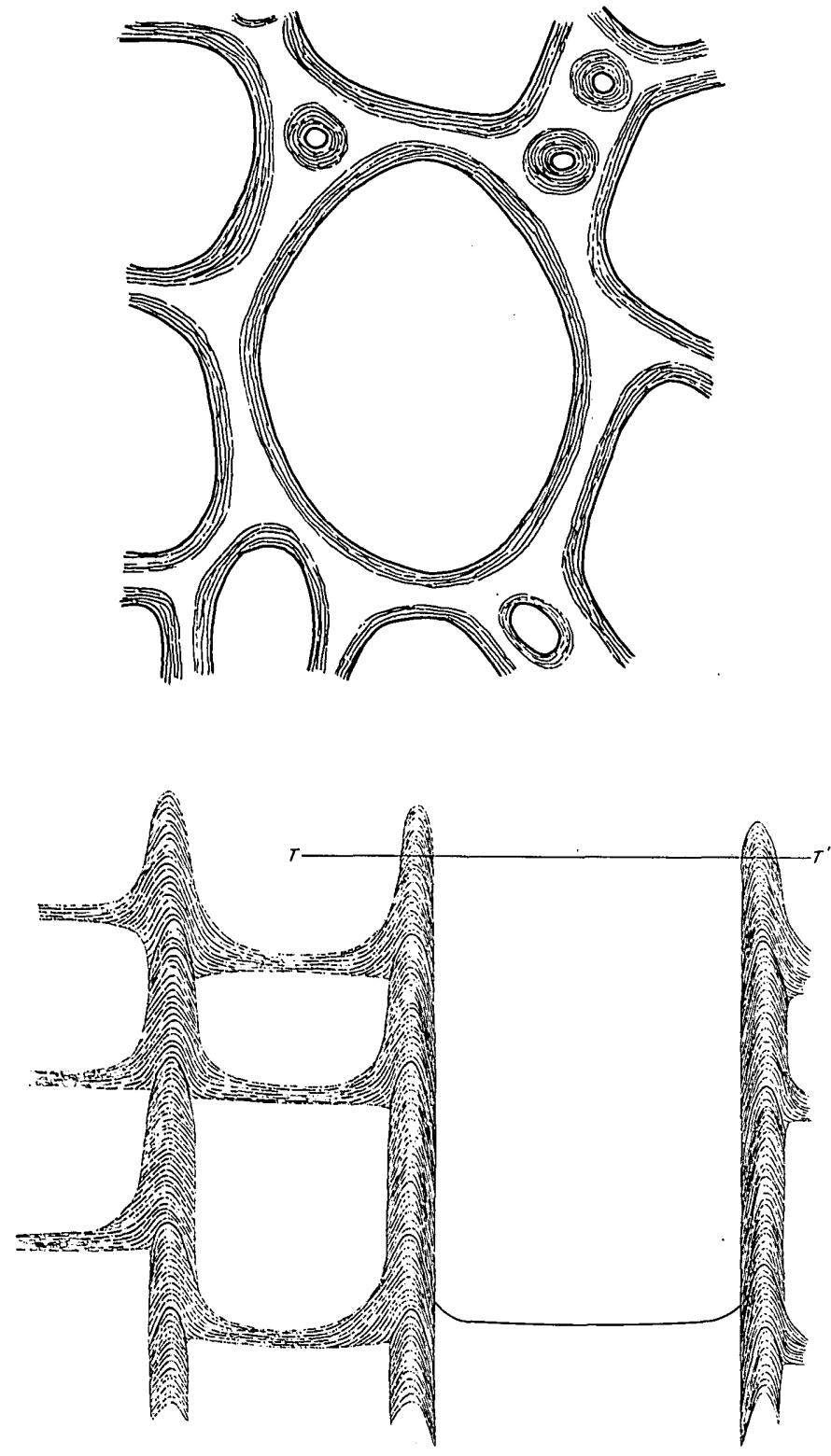

Figure 10.-Diagrammatic longitudinal and tangential sections of Leioclema Uirich. Line $T-T^{\prime}$ on the longitudinal view indicates the position of the trace of the plane of the tangential section. The tube containing the thick diaphragms is a mesopore. The tube on the right side of the longitudinal view containing a thin diaphragm is a zooecium. In the tangential view the small circular laminated structures are acanthopores, the central tube is a zooecium and the remaining tubes are mesopores surrounding the zooecium.

mesopores for a short distance before curving into the zooecial boundaries. Zooecial boundaries are intermittent or not discernible in species of Leioclema in longitudinal sections. If present, the boundaries are broad serrated zones of irregularly abutting laminae. The tangential view is always amalgamate but the hyaline areas are generally not as wide relative to the laminated zones as those of the stereotoechid group. The Devonian species of Leioclema show a general irregularity and imperfect parallelism of the individual laminae (pl. 4, fig. 8) making up the independent and wall-diaphragm units. Diaphragms are thin and widely spaced or absent in the zooecia.

TRACHYTOECHID WALL STRUCTURE

A third type of wall structure is best developed in Trachytoechus Duncan. As seen in longitudinal section of fig. 11, the zooecial wall laminae trend almost parallel to the longitudinal direction of the zooecia for appreciable distances, then curve distally out toward the zooecial boundary and intersect the boundaries at right angles. The boundaries are generally poorly defined in longitudinal sections. In tangential view, the walls are amalgamate and commonly exhibit mural lacunae. The major differences between trachytoechid and leioclemid wall structures are the mural lacunae and the greater lengths of those parts of the laminae that approximately parallel the zooecia in the trachytoechid walls.

Eridotrypella Duncan and Eridocampylus Duncan seem to have approximately the same type of wall structure as Trachytoechus. All three genera have strongly lacunose walls that look very granular in the Traverse species. Also, the thin walls of the neanic zone are noticeably crenulated in species belonging to these genera. However, lacunose and crenulated walls are not unique with these three genera. Both Trachytoechus and Eridocampylus typically possess heterophragms and some species now placed in Eridotrypella have heterophragms in small numbers.
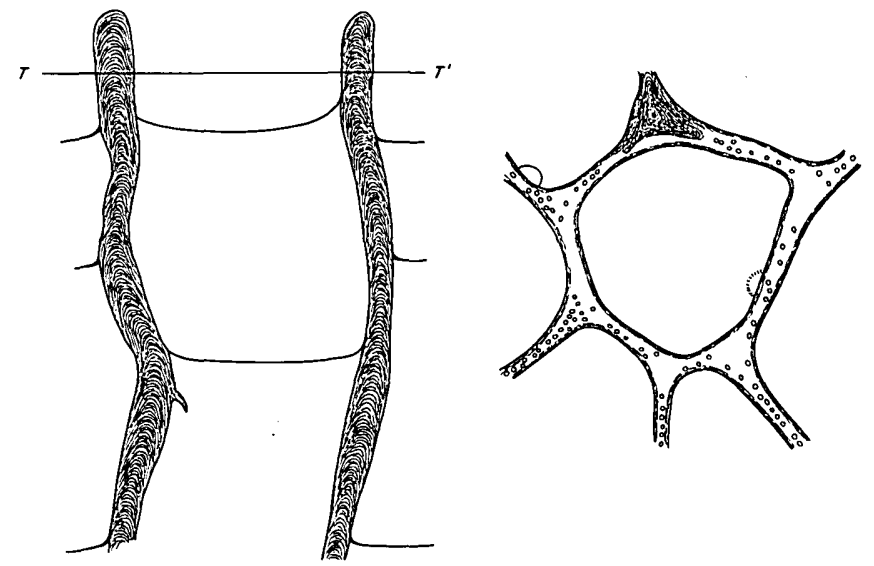

Figure 11.-Diagrammatic longltudinal and tangential sections of a single zooecium of Trachytoechus Duncan. Line $T-T^{\prime}$ in the longitudinal view indicates the position of the trace of the plane of the tangential section. The hooklike projection of the zooeclal wall in the longitudinal view is a heterophragm. In the tangential view, the walls are amalgamate and show the small pores in nonlaminated areas. The small semicircles attached to the zooecial walls are heterophragms as they appear in the tangential vfew. The heterophragm Indicated by hachures is suggestive of their appearance when fimbriate. The subtriangular area of laminated structure is the typical acanthopore in the species Trachytoechus hyalinus Boardman, n. sp. 
LEPTOTRYPELLID WALL STRUCTURE

The genus Leptotrypella Vinassa de Regny demonstrates a fourth type of wall structure. As seen in longitudinal section (fig. 12), the laminae of the diaphragms enter the zooecial walls and continue distally as a zooecial lining. The laminae of the lining run parallel to the longitudinal direction of the zooecia for relatively long distances and generally pass under 1 or 2 distally located diaphragms. At any point along the length of a zooecium in the ephebic zone the cumulative deposits of 2 or 3 diaphragm-wall units form a fairly continuous zooecial lining. The individual laminae of the diaphragm-wall units finally either lose their identity or can be seen to curve distally out to the zooecial boundaries. In a few species such as Leptotrypella furcata (pl. 11, fig. 5a) diaphragm-wall units do not form a distinct zooecial lining even though the laminae do parallel the zooecia for a considerable distance. In some other species of Leptotrypella apparent zooecial linings are thin or discontinuous. The zooecial boundaries are typically marked by a ragged serrated zone of irregularly abut-

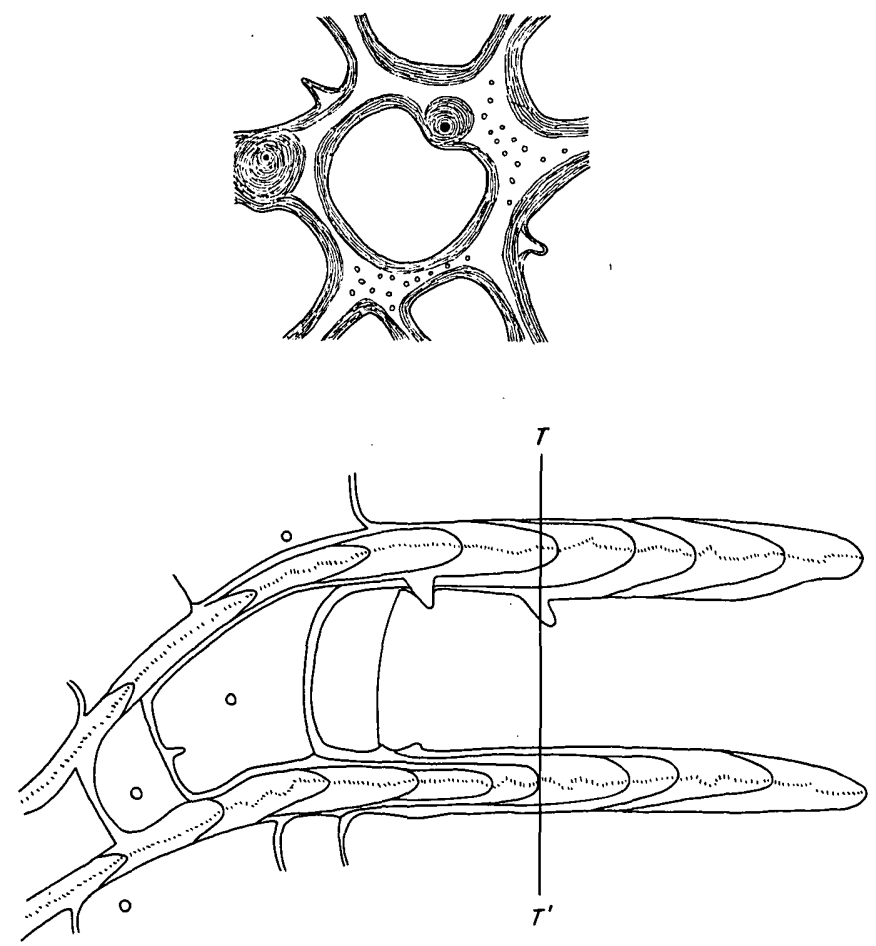

Figure 12-Diagrammatic longitudinal and tangential sectlons of single zooecium of Leptotrypella Vinassa de Regny. Line $T-T^{\prime}$ in the longltudinal view indicates the position of the trace of the plane of the tangential section. In the longitudinal section, the laminae parallel the widely spaced lines that indicate the boundaries of diaphragm-wall and independent wall units. The hachured irregular line indicates the position of the serrated zooecial boundary zone. The more proximal of the two mural spines projecting from the upper wall was formed earlier than the distal spine and is partially buried by subsequent wall deposits. The tangential view is amalgamate with scattered mural lacunae in the vitreous area. The two large circular laminated structures inflecting the zooecial walls are acanthopores. ting laminae from adjacent zooecia (pl. 10, fig. 3; pl. 14, fig. 1d). The tangential view is typically amalgamate, but several species appear to be integrate or show a combination of amalgamate and integrate features (pl. 6, figs. 6, 8b). Mural lacunae are common in several species of Leptotrypella.

In addition to Leptotrypella, Polycylindricus Boardman, n. gen. is tentatively included in this group.

\section{ATACTOTOECHID WALL STRUCTURE}

Typical wall structure is illustrated by the genus Atactotoechus Duncan. As seen in longitudinal section (fig. 13), the zooecial laminae remain relatively straight as they approach the zooecial boundaries and intersect the boundaries at low angles. Zooecial walls are formed by various combinations of diaphragm-wall units and independent wall units. Laminae entering the walls from the diaphragms either are inclined distally toward the zooecial boundaries and are relatively short, or parallel the zooecia for appreciable distances and then trend gradually to the boundaries. The laminae remain relatively straight as seen in the two dimensions of the longitudinal thin section and
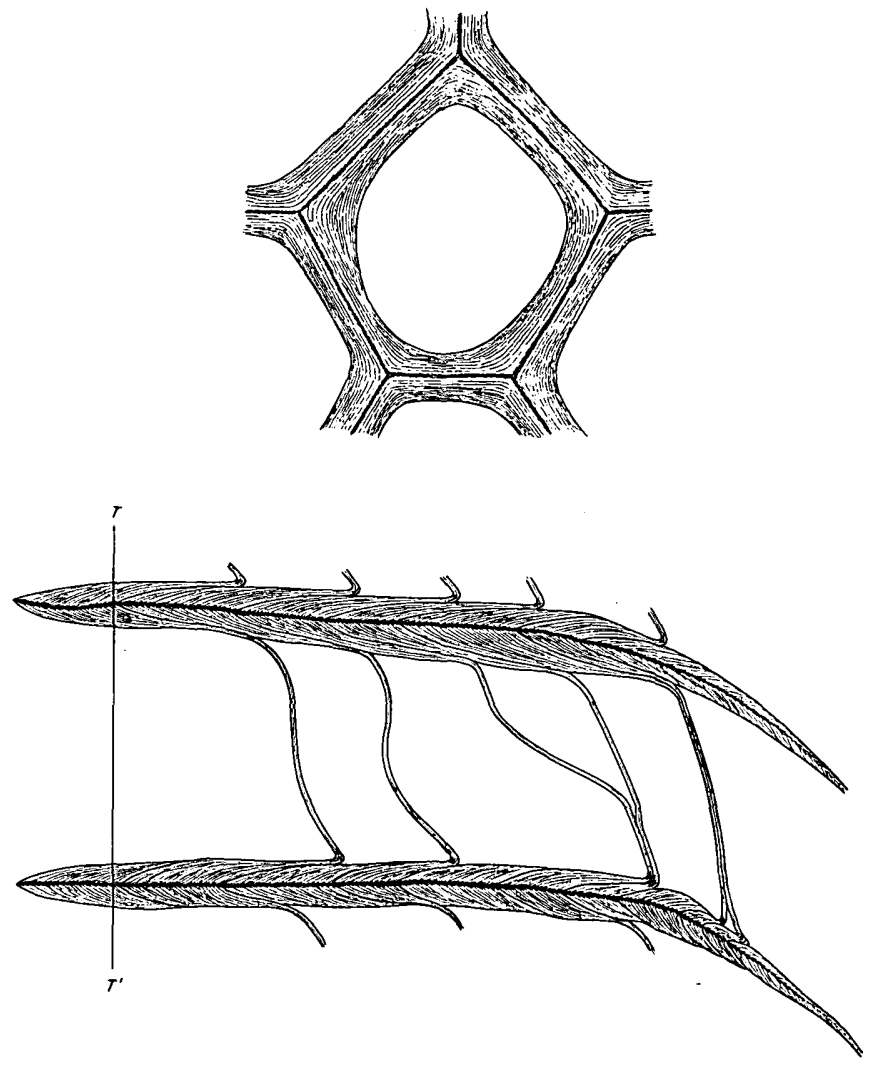

Figure 13.-Diagrammatic longitudinal and tangential sections of a single zooecium of Atactotoechus Duncan. $T-T^{\prime}$ in the longitudinal section Indicates the position of the trace of the plane of the tangential section. The curved diaphragm forming a large subtriangular chamber in combination with the straight diaphragm is termed a cystoidal diaphragm. The most proximal diaphragm is a compound diaphragm formed by two simple diaphragms uniting over the greater part of their area. 
intersect the zooecial boundaries at varying angles of less than 90 degrees. The zooecial boundaries are defined by a-relatively straight line formed by the junctions of laminae from adjacent zooecia. The laminae may be abutting at the boundary or apparently continuous without break across the boundary. In the Hamilton specimens, boundaries either are darker or comparable to the shade of the surrounding wall deposits. In tangential sections the walls are generally integrate, but can appear narrowly amalgamate, depending on the angle that wall laminae make with the zooecial boundary.

In addition to Atactotoechus, Loxophragma Boardman, n. gen. is placed in this group. In both genera, acanthopores are relatively few and small; diaphragms are closely spaced; and curved, cystoidal, and compound diaphragms and cystiphragms occur in varying numbers.

\section{ZOARIAL GROWTH AND TAXONOMY}

The common occurrence of associated fragments of single ramose zoaria in the Hamilton group of New York State offers an unusual opportunity for the investigation of possible morphologic variation within zoaria and their method of growth. The existing literature provides little more than generalized observations and subjective interpretations regarding the amount of variation in complete zoaria of fossil Bryozoa. As a result, morphologic characters that are largely controlled by the stage of development within a zoarium have not been uniformly or adequately considered in the taxonomic study of the Trepostomata. In differentiating and describing species, astogenetic characters either have been ignored or considered to be relatively constant, and in some instances many names have been proposed for a single species. The ramose and fenestrate forms that are commonly found only as disassociated fragments are most likely to be misinterpreted. Cumings (1904, p. 50) mentioned the importance of this factor:

It must be borne in mind that a colony or stock composed of a number of individuals may be properly characterized as nepionic, while some of the individuals composing it are in reality mature, senile, or even dead.

And:

Enough has been determined, however, to make it certain that the founding of species upon slight variations occurring on small fragments of zoaria is an exceedingly questionable practice. The modifications of zoaria due to age may be profound. The writer has, for example, seen hundreds of specimens of most exceptionally well-preserved lower Helderberg and Hamilton Bryozoa, in very many cases showing the entire zoarium. These specimens make it perfectly certain that many of the species that have been enumerated from these formations, and founded on fragments of zoaria, are spurious. They may often enough represent merely different growth stages of a single individual. The only reliable criterion of a species is the entire zoarium (Cumings, 1904, p. 66).

The same caution has been expressed by L. W. Stach in work on Cenozoic and Recent Bryozoa. He ascribes morphologic variation within a zoarium and species to two factors: "(a) The difference in age of the zooecia in a zoarium which is generally expressed by the degree of calcification; and (b) the interplay between the tendency to a uniform development of all the zooecia and the environmental conditions in the neighbourhood of certain zooecia" (1935, p. 646).

\section{DISTRIBUTION OF MORPHOLOGIC CHARACTERS WITHIN HAMILTON ZOARIA}

Zoaria of Leioclema confertiporum (pl. 3, fig. 2b), Leptotrypella multitecta (pl. 7, fig. 1a), L. asterica (pl. 9, fig. 1a), and L. tuberata (pl. 14, fig. 2b) were assembled in nearly complete form. Most of the other ramose species are represented by at least one relatively large part of a zoarium. In rocks of the Hamilton group, the fragmented zoaria occur in isolated lensshaped masses or more rarely imbedded in the matrix in approximately their original configurations. All attempts to assemble the zoaria were at least partially successful indicating that each isolated concentration can be assumed to contain many fragments from at least one zoarium. After the zoaria were assembled, a continuous series of longitudinal thin sections was made from one of the main branches in each of a number of zoaria selected for study and the internal features were recorded in detail. Figs. 14, 15, and 21 are based on three zoaria that were sectioned continuously from the most proximal fragments to the growing tips. Other assembled zoaria were sectioned at their extremities and at several intervening regions to determine the nature and limits of their variation. Zoaria that could not be assembled because of the difficulty of freeing the broken pieces from hard unweithered shale or because of too many missing pieces, were studied by sectioning a number of fragments chosen at random. In addition, sections were made of growing tips, fragments having the largest transverse diameters, branching stems, and fragments of any unusual appearance.

In the ramose Hamilton trepostomes the diameter of the inner thin-walled neanic zone of a zoarium does not become progressively smaller from bottom to top (figs. 14 and 15) but appears to vary erratically without regard to position in the zoarium. An increase in the diameter of the neanic zone generally occurs just proximal to the dichotomous branching of a stem (pl. 9, fig. 1f). This expansion is due to a multiplica- 


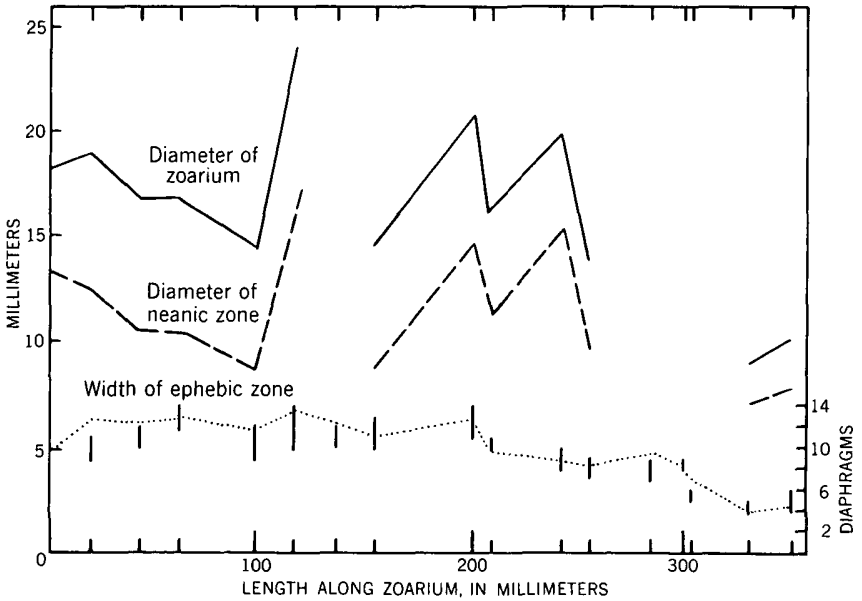

Figure 14.-Graph of holotype of Leptotrypella (Leptotrypella) asterica Boardman, n. sp. (pl. 9). Vertical lines indicate numbers of diaphragms according to scale in right margin of figure.

tion in the number of zooecia as a result of an increase in the rate of gemmation of zooecia in the neanic region.

The total diameters of the branches are controlled largely by the width of the neanic regions, which constitute well over half of the total branch diameters in most species. As a result, branch diameters ordinarily show no progressive decreases distally, (figs. 14, 15) similar to the neanic diameters. Branch diameters are locally affected by patchy areas of overgrowth that cause bulbous swellings and other irregularities in extreme developments.

In a large well developed ramose zoarium (fig. 14) the width of the outer thick-walled ephebic zone is relatively constant from the base upward for a considerable distance. Distal to this stable part of the

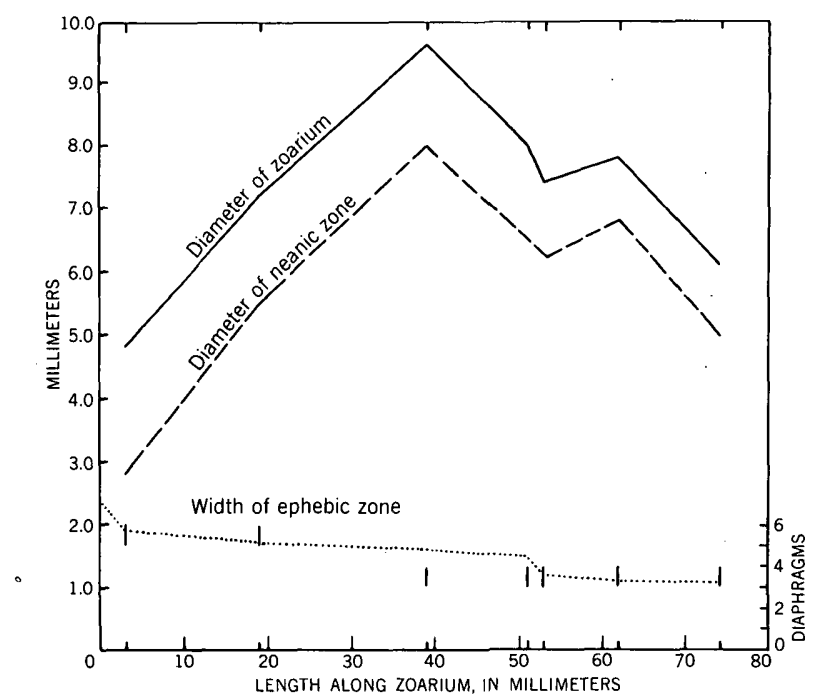

Figure 15.-Graph of zoarium 3524-17 of Leptotrypella (Leptotrypella) multitecta Boardman, n. sp. Vertical lines indicate number of diaphragms according to scale in right margin of figure. zoarium, the ephebic zone progressively diminishes in width, becoming narrowest at the growing tips. Of the 188 growing tips sectioned, 82 percent show a thick-walled ephebic zone of some extent at the distal tips of the zoaria. The remaining 18 percent of the growing tips display zooecia possessing thin walls throughout. Figure 15 is based on a partly reconstructed zoarium representing either the distal part of a much larger zoarium or a nearly complete young zoarium since the width of the ephebic zone decreases progressively along the length of the available branch.

The number of diaphragms in the ephebic zones of the zooecia is approximately proportional to the corresponding widths of the zones (figs. 14, 16), so that diaphragms become progressively fewer distally as the ephebic zones decrease in width (pl. 7, fig. 1; pl. 9). Presumably, diaphragm counts and width of ephebic zones can be proportional to growth stages of zooecia considering the manner of skeletal growth (p. 27). The number of diaphragms in zooecia within a single zoarium of Atactotoechus fruticosus (p. 76) ranges from 27 in proximal regions to 1 or 2 in growing tips.

Zooecial diaphragms are too few and irregularly spaced to be used as indicators of growth stages in genera such as Dyoidophragma Duncan and Leioclema Ulrich. In this study the hemiphragms of Dyoidophragma and the diaphragms in the mesopores of Leioclema are relied upon as convenient growth stage indicators, because these structures are uniformly spaced in the ephebic zones and appear to have the same structural relationships and age significance as zooecial diaphragms in other genera.

The axial ratio is the ratio between the diameter of the neanic zone and the total diameter of the branch (fig. 19). As has been noted, the neanic zone shows no progressive changes in diameter in a zoarium so can be considered essentially constant for a large zoarium when considering ontogenetically controlled morphologic variation. The ephebic zone, however, becomes narrower distally so that branches consist of a progressively larger proportion of neanic zone and a correspondingly smaller proportion of ephebic zone. Thus, the value of the axial ratio becomes greater distally as the growth stages of the zooecia in a zoarium become younger (fig. 17). The axial ratio then is another indicator of ontogenic development but is affected by local irregularities in neanic zone diameters and generally is not as reliable for growth interpretations as the width of the ephebic zone or the number of diaphragms in the zooecia. The axial ratio is especially misleading if it is based on measurements of regions just proximal to dichotomy because the neanic 
zones at these places are larger than normal, whereas the ephebic zones do not exhibit comparable changes. Consequently, the values of the axial ratios measured just proximal to dichotomy of a branch are too high to give an accurate idea of the stage of zoarial development that had actually been attained.

Zooecial wall thickness shows little correlation with growth stages defined by the width of ephebic zones and numbers of diaphragms. In general, walls attained their maximum thickness at the point where the third or fourth diaphragm occurs in the early ephebic zone so there is no general increase in wall thickness as diaphragms were added subsequent to this early growth stage.

The zooecial surface angle is reasonably constant in most ramose species and varies little from $90^{\circ}$ in most genera studied. However, in Atactotoechus cartus the angle is unusually small and shows a poor correlation with growth stages (fig. 18) becoming generally larger in older parts of the zoarium.

Mural spines and small spherical cysts occurring in Leptotrypella are ordinarily distributed irregularly through a zoarium. In zoaria displaying few mural spines, several may be seen in one thin-section and none in another from the same zoarium. Zoaria containing abundant mural spines have a concentration of them near the zooecial bends. A concentration of spines commonly occurs at the proximal ends of zooecia in incrusting overgrowths (pl. 8, fig. 7). Cysts appear to be abundant in some parts of a zoarium and rare in other parts (pl. 9, fig. 1). Where abundant, they are distributed throughout the length of the zooecia in the ephebic zone without any noticeable concentration.

Characters seen in the tangential views are normally more constant throughout a zoarium than those characters displayed in longitudinal views. The only important exceptions to this general observation are the variability of the zooecia in the monticules and the irregular occurrence of amalgamate and integrate zooecial walls in some species.

Monticules are fairly evenly spaced throughout a zoarium. However, the nature of the included elements may be extremely variable. One monticule may contain many mesopores and adjacent monticules in the same zoarium few or none; or some monticules may display thick-walled zooecia and enlarged acanthopores and others in the same zoarium may contain zooecia of normal wall thickness and acanthopores of normal size.

The diameters of zooecia vary within the small area covered by a tangential thin section, and the variation throughout the zoarium is approximately equal to that determined from the single section. Configuration of the zooecia as seen transversely is somewhat variable but does not progressively change from one part of the zoarium to another.

The distribution of mesopores and acanthopores in the intermonticular areas is relatively constant throughout a zoarium. Ontogeny has no effect on their occurrence, for both mesopores and acanthopores have their origins at the beginning of the ephebic zone in the Hamilton species. Once these structures appear, they do not multiply noticeably as ephebic growth continues.

\section{ZOARIAL VARIATION AND SPECIES CRITERIA}

Fortunately, it is not necessary to have complete zoaria to do realistic taxonomic work, once the growth characteristics, based on related zoaria, have been reasonably well established. With regard to taxonomy, a colony can be thought of as merely a convenient physical linking of individuals of similar genetic makeup. These individuals may or may not display a number of progressively changing growth stages superimposed on morphologic variations due to either physiological or microecological differences. Since the average sized fragment represents a restricted growth stage, a reasonable number of disassociated fragments of a species provide an adequate approximation of the range and morphologic characteristics of the growth stages and at least those morphologic variations that are fairly evenly distributed within the colonies.

The characters discussed in the preceding section on morphologic variation within zoaria are those most often used in differentiating species. These species characters fall into two natural groups: those that are independent of ontogeny, and those controlled largely by ontogeny or growth stages. Species characters that are independent of ontogeny form two subcategories: (a) characters that display relatively large variations distributed erratically in a zoarium, and (b) characters that remain relatively constant throughout a zoarium.

The use in taxonomy of the characters subject to erratic variation will always be seriously hampered by the general lack of complete zoaria. The nature and limits of variation of the erratic characters for the zoarium cannot be determined from a small fragment. Thus, the erratic characters are generally poorly understood, and therefore less useful in taxonomy. Good examples of such characters are the mural spines and cysts of Leptotrypella and the nature of the monticular zooecia in many of the Hamilton species.

Characters of the second category that show little variability throughout the zoarium are much more 
useful as criteria for species. In general, a fairly good idea of the nature and amount of variation within a zoarium can be obtained from one or two fragments of that zoarium. In the Hamilton material, characters that have been found to be fairly constant within a zoarium include zooecial wall thickness, shapes of the zooecia in transverse view, numbers of acanthopores and mesopores per zooecium, nature of the walls (crenulate or non crenulate) in the neanic zones, nature of the zooecial linings and boundaries, occurrence of cystiphragms and compound diaphragms, and zooecial surface angles. However, any one of these characters can vary erratically in certain species and genera and should be used with a certain amount of caution.

The relatively constant characters commonly vary in some degree, depending on the species, from one zoarium to another. Fragments from a reasonable number of zoaria must be examined before a species concept can be defined with assurance. Large numbers of sections, about 330 sections from 46 zoaria, of Leptotrypella asterica (p. 58) were studied in an attempt to describe this extremely variable species. As indicated in the species description, wide ranges of variation were found in certain characters that are generally fairly constant. The variations of several of these characters are apparently related and can be correlated. It can be demonstrated in a few zoaria that intrazoarial variations of such characters as wall thickness and spacing of diaphragms are approximately proportional and are wide ranging.

Most zoaria of $L$. asterica show these same characters to be relatively constant within a zoarium. However, interzoarial variation in this larger group is comparable to that variation found in a single zoarium in the few inconstant zoaria of the species. The only safeguard for interpreting such a variable species is a large number of specimens. Also, the presence of the complete range of variability in a single zoarium constitutes a happy verification for the inclusion of widely variable zoaria in one species.

Zoarial growth habit has been considered to be an infallible species character in Paleozoic forms. Growth habit is a reliable species criterion for many and probably most species, but there are exceptions (p. 8). Several Hamilton species that ordinarily display conspeçific overgrowths on ramose zoaria also produce incrusting zoaria or a combination of incrusting and ramose zoaria on nonbryozoan surfaces. Thin-sections illustrating combined growth habits in a single zoarium or different growth habits within single species are shown on pl. $3 ;$ pl. 7 , fig. $3 ;$ pl. 11, fig. $6 ;$ pl. 17 , fig 4 ; and pl. 22 , fig. 1 .
The group of species characters controlled by ontogeny is relatively small but should prove exceedingly useful in taxonomy. Characters of this type are best adapted to statistical studies based on scatter diagrams, for such diagrams can be designed to demonstrate growth stages. The width of the ephebic zone, number of diaphragms, axial ratio, and in a few species the zooecial surface angle are characters that lend themselves to such analysis. The ontogenetic characters were found to vary so widely within one zoarium that as many as three "species" could be distinguished from one end to the other. Thus, a wider more realistic range of species variation must be allowed in structures that are controlled by growth stages.

The ontogenetic characters can be treated successfully in the ordinary collection composed of small disassociated fragments of zoaria if a reasonable amount of material is available for a species. First, it is necessary to establish a means of defining growth stages. The number of zooecial diaphragms at a particular level in the zoarium is considered the independent variable in most of the Hamilton genera. It is generally assumed that the diaphragms served as floors upon which the soft polypides rested. Each additional diaphragm then, represented an advance in the distal growth of the individual and the passage of an unknown amount of time (p. 27):

It is not necessary to know the absolute range of the number of diaphragms possible in a species being described. Due to the nature of growth in ramose zoaria, the minimum number of one to a few diaphragms is assumed possible in the ramose Hamilton species. The maximum number of diaphragms will ordinarily not be known. However, a growth stage of a restricted number of diaphragms can be defined and further characterized with reference to the corresponding values of the other ontogenetic characters. Several arbitrarily restricted growth stages, will have a set of corresponding values for the dependent variables that will characterize individual species. The wider the range covered by a series of growth stages and the more specimens measured for each growth stage, the more accurate is the characterization. These figures can then be presented in the form of scatter diagrams and resulting statistical tests, or they may be presented in tabular form as is done in the taxonomic section of this paper.

Figures 16 to 19 are based on three zoaria (in fig. 18, four zoaria are included) of Atactotoechus cartus cartus (p. 73). The three zoaria are part of a collection of 13 that were obtained from the Portland Point member in USGS collection 3551. The zoaria occurred as isolated, lens-shaped masses of broken 


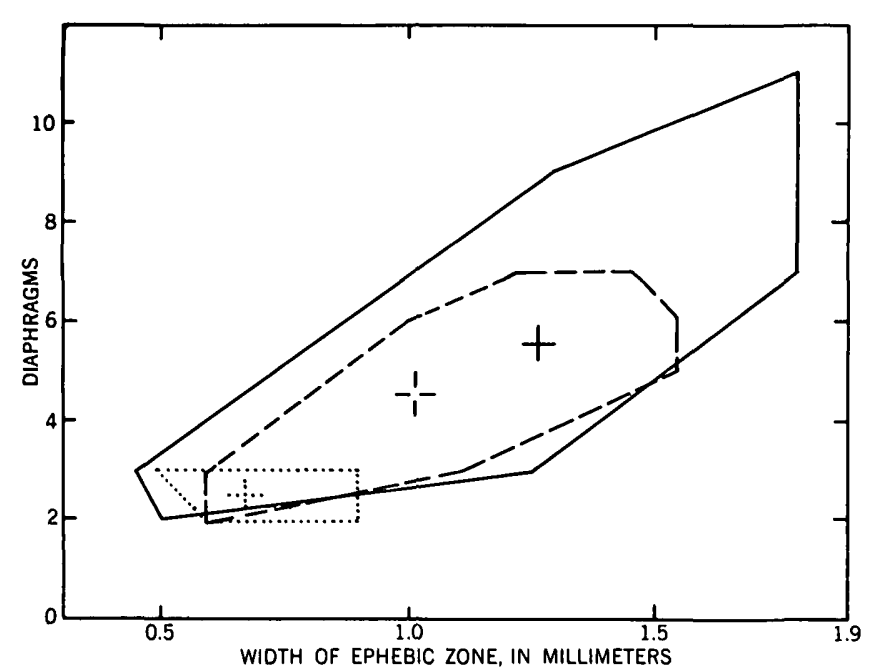

Fiourn 16. Peripheral scatter diagram of three zoaria of Atactotoechus cartus cartus from. collection 3551 . The area defined by the plotted points of each zoarium is enclosed by a line. Each style of line identlfies the same zoarium in figures 16 to 19 . The crosses indicate the median points of the respective zoaria.

fragments in a 3-foot stratigraphic zone along 360 feet of the stream channel of Menteth Creek on Canandaigua Lake. Because the mudstone matrix was relatively hard and unweathered, it was impractical to clean each of the many fragments and attempt to assemble the zoaria. The writer assumed that each isolated mound of material was a separate zoarium

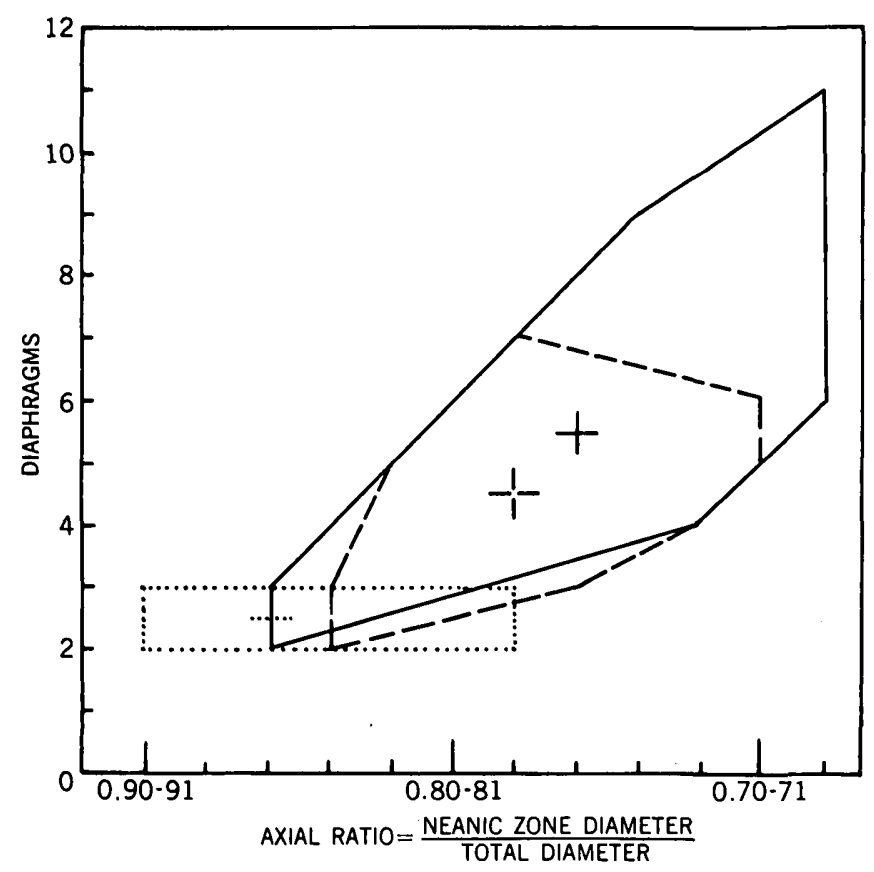

Fioune 17.-Perjphernl scatter dingrum of three zoaria of Atactotoechus cartus cartus from collection 3551 . The area defined by the plotted polnts of ench zoarium is enclosed by a line. Each style of line Identifies the sume zonrium in figures 16 to 19 . The crosses indicate the median points of the respective zoaria.

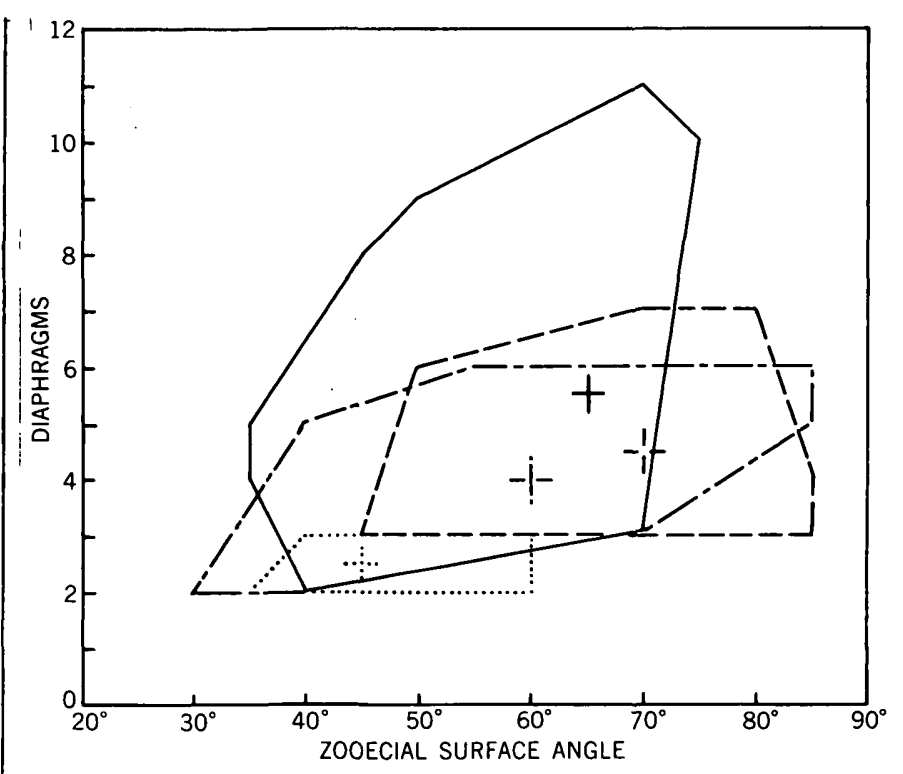

Figure 18.-Peripheral scatter diagram of the three zoaria of 1 Atactotoechus cartus cartus that are represented in figures 16 to 19 plus a fourth zoarium from the same collection, 3551. The area defined by the plotted points of each zoarium is enclosed by a line. The crosses indicate the median points of the respective zoarla.

(p. 74). As many as 30 longitudinal sections were made from fragments picked at random from each lot. The 3 zoaria chosen for the graphs illustrate the ontogenetic and astogenetic range of variability observed in the 13 zoaria.

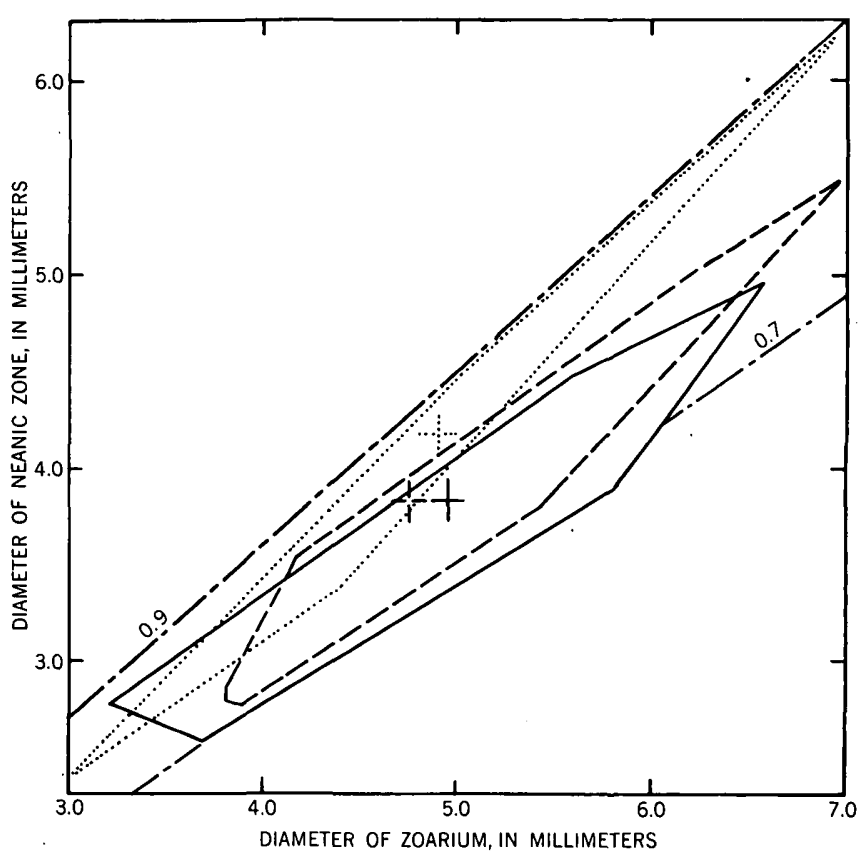

Figure 19.-Peripheral scatter diagram of three zoaria of Atactotoechus cartus cartus from collection 3551 . The area defined by the plotted points of each zoarium is enclosed by a line. Each style of line identifies the same zoarium in flgures 16 to 19 . The crosses indicate the median points of the respective zoaria. 
The differences between zoaria represented in figures 16 to 19 are all based on characters that are controlled by ontogeny. Apparently, each of these three zoaria had attained a different stage of astogenetic development at the time it was killed. The zoarium represented by the solid line is interpreted to have reached the most advanced stage of development because it shows the greatest numbers of diaphragms, the lowest axial ratios and widest ephebic zones. Also, the complete range of growth stages occurs in this zoarium as is indicated by the area covered by its scatter diagram extending to the smallest numbers of diaphragms, the narrowest ephebic zones, and high axial ratios. The zoarium represented by the dotted line was the youngest as indicated by the position of the area representing that zoarium at the lower left hand corners of the diagrams in figures 16-18. The colony represented by the dashed line reached an intermediate stage of zoarial development. The crosses indicating median points of the three zoaria are aligned from the lower left to the upper right in the order of least to greatest ontogenetic development and give some indication of the average growth stage of each zoarium.

Figures 16 and 17 dealing with the number of diaphragms, width of ephebic zones, and axial ratios show fairly good correlation as might be expected. Figure 18, in which the zooecial surface angle is plotted against the number of diaphragms, shows very poor correlation. In general, the zooecial surface angle is not a good indicator of growth stage.

Figure 19 is a plot of the diameters of the zoaria against the diameters of the neanic zones thus illustrating the axial ratio. The youngest zoarium has the highest axial ratios and therefore is confined to the area near the 0.9:1 line. The most mature zoarium represented by the solid line shows an axial ratio approaching the $0.9: 1$ line and crossing the $0.7: 1$ line in older parts of the zoarium. The extremely elongated areas indicate a good correlation between these two measurements. Good correlation is expected because the neanic zone constitutes such a large proportion of the total branch diameter, as is indicated by the high values of the ratios.

\section{MODE OF RAMOSE ZOARIAL GROWTH}

The present investigation of the unusually well preserved Hamilton specimens has resulted in an hypothesis concerning the mode of growth of the ramose colonies.

Lee (1912, p. 143) after a study of Carboniferous trepostomes, concluded that the axial ratio (ratio of the diameter of the neanic zone to the diameter of the branch) is constant within a zoarium and a species. His theory of constant axial ratios led him to propose a resorption theory of growth for ramose colonies. Apparently, Lee found that all of his specimens had well-developed ephebic zones across their growing tips. According to Lee, as the branch increased its length distally, growing zooecia located in the center of the branch curved outward from the branch axis, keeping their ephebic zones constant in width by resorbing the proximal ends of the ephebic zones and depositing at an equal rate at the distal ends. This compensating process brought the zooecia to their final positions in the cortical or ephebic zone of the zoarium. At this stage the ephebic zones were apparently considered to be fully developed and outward growth of zooecia ceased, for Lee states (1912, p. 144) that branches possess their full diameter from the beginning, and further comments:

*** in each species the dimensions of the axial and peripheral regions not only are invariably the same in branches of the same diameter, but also that in the smallest as well as in the largest these two regions have invariably the same relative proportions (1912, p. 143).

Study of the ramose forms of the Hamilton specimens indicates that resorption of skeletal material was probably part of the growth processes of the colonies. Otherwise, there is little agreement between Lee's hypothesis and that presently favored for the Devonian material.

Study of sectioned growing tips and relatively long branches that were sectioned in their entirety provides three main observations that must be considered in a growth hypothesis. First: narrow arched zones paralleling the rounded ends of the branches extend across the neanic regions at irregular intervals proximal to the tips. The zooecia at these zones contain one or more diaphragms and the walls are thickened to some extent (pl. 7 , fig. 2 ; pl. 9 , figs. 1e, 1 f; pl. 10, figs. 2,5 ; pl. 19, fig. 4). The thick-walled zones within the neanic regions have the same general appearance as the proximal parts of ephebic zones (pl. 10, figs. 2, 5). Second: about 80 percent of the growing tips show thick-walled ephebic zones that are as long or longer than the thick-walled zones of the neanic regions proximal to the tips (pl. 7, fig. 2 ; pl. 9, fig. 1e; pl. 10, fig. 5 ; pl. 22, fig. 2 ). Third: ephebic zone width, number of diaphragms and axial ratio all indicate that there is a gradual decrease in astogenetic development through a considerable length of the distal end of each zorium.

These observations are interpreted to indicate that growth was cyclic and that the thick-walled zones arching across the neanic regions represent abandoned 
growing tips that underwent varying amounts of resorption. A suggested cycle of growth in a ramose colony is as follows: new zooecia were introduced by lateral gemmation in the neanic zone; the new zooecia along with those persisting in the neanic zone from earlier cycles grew distally, the cumulative effect extending the length of the branch. A thick-walled ephebic zone was then formed around the tip (fig. 20). Next, the polypides resorbed the skeletons from the apertures back toward the bases of the thickwalled region, removing distal lengths of the thick walls and associated structures such as diaphragms. The amount of resorption varied greatly among species and within one colony from cycle to cycle and was probably controlled in part by recurring environmental conditions. Another cycle began with the renewed growth and gemmation of thin walled tubes of the neanic zone. The new thin-walled growth was directly connected to the thick-walled remnants of the previous cycle thereby forming continuous tubes.

As the colony grew distally, zooecia at the growing tip were gradually forced away from the center of the branch, their places in the center taken by new zooecia formed by gemmation. The older zooecia

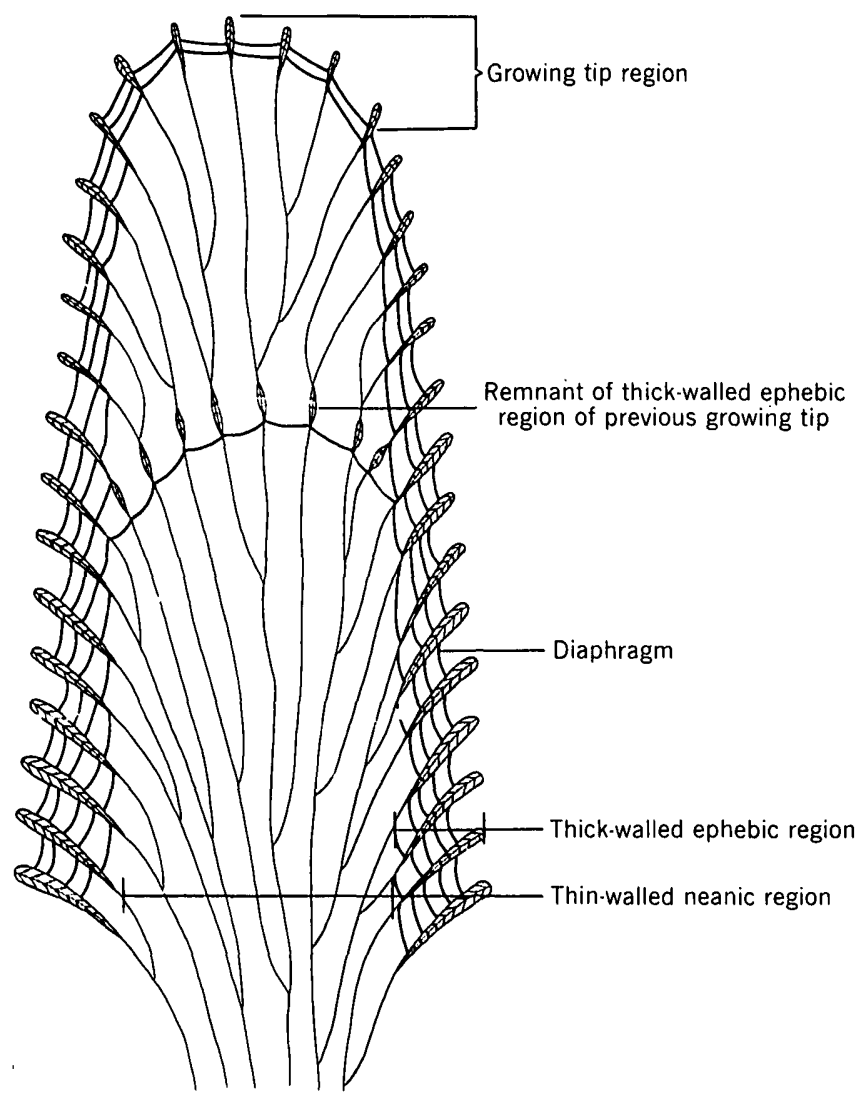

Frours 20.-Idealized diagram of a ramose bryozoan in longitudinal view illustrating the essential structures involved in the growth of a ramose colony. eventually attained permanent positions opening along the sides of the branch. Here, there are no signs of resorption such as is exhibited in the neanic zone and the growing tip. The present interpretation of complete diaphragms as "floors" that supported the polypides indicates that the living chamber was distal to the last formed diaphragm. It might be assumed that skeletal changes could have occurred only in regions adjacent to the polypide, thus any changes of the skeleton would have to proceed from the distal living chamber in a proximal direction. Further, the configuration of zooecial wall laminae indicates that zooecial growth was limited to the outer surfaces of the living chamber (p. 27). Width of the ephebic zone, number of diaphragms, and other intrazooecial structures increase progressively toward the base of a colony indicating that the distal growth of the zooids in the thick-walled ephebic zones continued roughly proportional to time. The observed progressive change in axial ratio then was controlled by a gradual addition of deposits in the ephebic zone and no accompanying change in the neanic zone, zoarial features that are consistent with this hypothesis of growth.

The relatively constant width of ephebic zones and numbers of included diaphragms in the most proximal part of large zoaria, such as the holotype of Leptotrypella asterica (fig. 14) indicate that zooids attained their maximum length and died, or at least ceased adding to their skeletons. The dead or dormant parts of zoaria served to support the growing parts and to keep them upright and above the accumulating bottom deposits. Whether the proximally located zooids were killed because accumulating deposits covered them or died before being covered because of physiologic limits to their growth is not known. Many Hamilton zoaria have overgrowths, not always conspecific, occurring in patches or completely covering their proximal regions. Zooids in the overgrown tubes were either already dead or were killed as the overgrowths covered them. Thus a large zoarium may be pictured as progressively dying from the base upward, growing normally in distal regions and covered here and there by patches or sheets of living overgrowth.

An overgrowth is almost completely separated from the incrusted or primary colony by a basal lamina. Leptotrypella multitecta ordinarily displays well developed overgrowths that seem to have originated from a few zooecia in the incrusted colony. Pl. 7, fig. 4a shows a large section of the holotype that includes the probable origin of an overgrowth that is both incrusting and ramose. The zooecia at the end of the primary colony continue into the secondary colony or overgrowth without interruption, forming a source 
for the secondary colony. The secondary colony grew distally in all directions from the restricted region of its origin. The normal curve or bend of a zooecium is always concave in the proximal direction of growth. The incrusting overgrowth in part extended downward, relative to the primary colony, but since that direction is distal relative to the secondary colony the orientation of the zooecia of the overgrowth is reversed relative to the primary colony, as is seen in the upper center and lower left part of the figure (pl. 7, fig. 4a). Fig. 21 shows the decrease in width of the ephebic zone of the incrusting part of the secondary colony away from its origin and toward the base of the primary branch. In addition, overgrowth grew distally upward (upper right corner of fig. 4a of pl. 7) in the form of a branch, there being no support for incrusting growth in this direction.

In addition to the ordinary dichotomous branching of ramose colonies and the erratic branching resulting from overgrowths, the genus Polycylindricus commonly displays a "secondary" type of branching resulting in discordantly small branches projecting at right angles to the supporting stem (pl. 16, figs. 2,4). These small side branches are formed by normal thinwalled tubes that arise from the thick-walled tubes of an ephebic zone without the intervening basal lamina that occurs in normal overgrowth. Local and relatively rapid growth of the thin-walled tubes apparently provided a neanic region for the secondary branch. Similar branching is known in Leptotrypella mesostena mesostena (p. 55) and Atactotoechus fruticosus (p. 76).

The nature of the basal attachments of ramose colonies has not been satisfactorily revealed by the Hamilton material. Zoaria showing combinations of incrusting and ramose habit as in pl. 7, fig. 3 ; pl. 11, fig. 6 ; and pl. 22 , fig. 1 , may represent either normal basal attachments or small colonies that were as much ramose as incrusting. The scarcity of zoaria showing both incrusting and ramose habit might indicate that

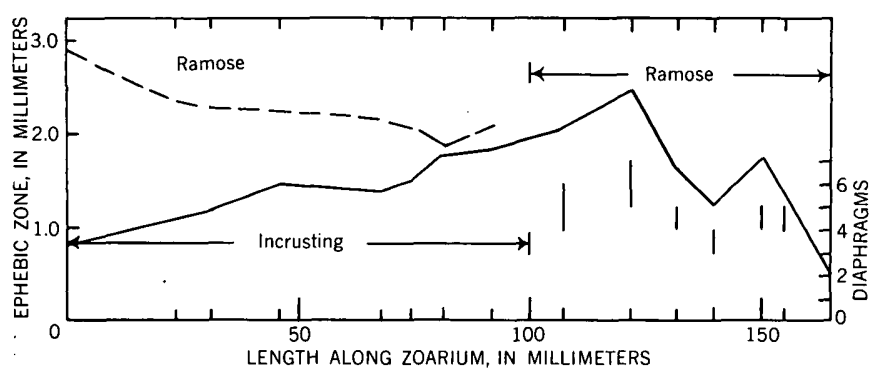

Figure 21.-Graph of holotype of Leptotrypella multitecta Boardman, n. sp. The dashed line indicates the width of the ephebic zone of the primary colony. The solid line indicates the width of the ephebic zone of the secondary colony, in part incrusting on the primary colony and in part extending beyond the primary colony as a branch. such colonies were rare and the basal attachments of the great majority of ramose colonies were of a different nature.

\section{SYSTEMATIC DESCRIPTIONS}

\section{Order TREPOSTOMATA Ulrich, 1882 \\ STEREOTOECHID GROUP}

Genera from the Hamilton group that display zooecial wall structure similar to that of the genus Stereotoechus Duncan are placed together. The zooecial wall laminae of the included genera are typically short, broadly curved throughout their length, and largely transverse to the length of the zooecia (see p. 30 and fig. 9).

\section{Genus STERE0TOECHUS Duncan}

1939. Stereotoechus Duncan, Univ. Michigan, Mus. Paleontology, Contr., v. 5, p. 260.

1939. Anomalotoechus Duncan (part), ibid., p. 187.

Type species.-Stereotoechus typicus Duncan 1939. Original definition.-Zoarium laminar, superimposed layers may form small masses. Groups of larger zooecia present. Walls thick, completely amalgamate, laminated, irregularly thickened at frequent intervals, occasionally slightly beaded. Diaphragms complete and numerous. Mesopores absent. Acanthopores well defined, laminated, located at or near junctions of zooecial walls.

Remarks.-Mesopores, as defined in this paper, are very rare in some species and unknown in others. Diaphragms are uniformly thin in this genus.

Leptotrypa? spinifera Duncan (1939, p. 222, pl. 5, figs. 3-5) is here reassigned to Stereotoechus. Anomalotoechus typicus Duncan (1939, p. 189, pl. 1, figs. 4-7) the type species of Anomalotoechus, is considered to be a synonym of S. spiniferus (Duncan) differing only in displaying a more advanced growth stage. Holotype specimens of both $S$. spiniferus and $A$. typicus possess a stereotoechid wall structure. Also, the diaphragms of $A$. typicus differ little in arrangement from Stereotoechus typicus, the type species of Stereotoechus, and all remaining characters of the holotypes of both L.? spinifera and A. typicus are consistent with the definition of Stereotoechus. The remaining species assigned to Anomalotoechus by Duncan (1939, p. 188) that do not belong in Stereotoechus are: Anomalotoechus tuberatus Duncan, now assigned to Atactotoechus (p. 70) and Monticulipora? marylandensis Ulrich and Bassler 1913, now placed in the synonymy of Leptotrypella amplectens (Grabau) 1899 (p. 60).

Cyphotrypa traversensis Duncan (1939, p. 200, pl. 4, figs. 10-12) displays a stereotoechid wall structure 
and the other characteristics of the genus and is here reassigned to Stereotoechus. Leptotrypa? nicholsoni Duncan (1939, p. 221, pl. 5, figs. 6-8) is considered a young growth stage of $S$. traversensis (Duncan) and is included in the synonymy of that species. Stigmatella alpenensis Duncan (1939, p. 233, pl. 4, figs. 4-6), Monticulipora monticula White $(1876$, p. 27), Cyphotrypa? shearsbyi Crockford (1941, p. 105, pl. 1, fig. A) and Orbignyella tenera Bassler (1911b, p. 61, pl. 8, figs. $1-3$; pl. 11, fig. 3) are reassigned to Stereotoechus.

The following species are now assigned to Stereotoechus :

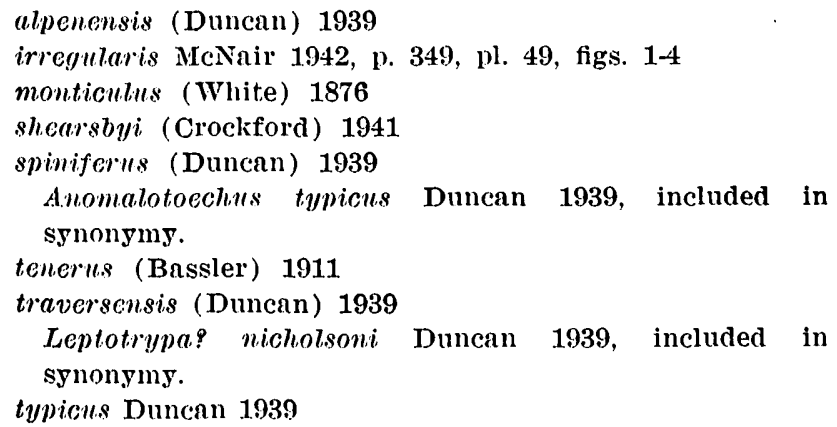

\section{Stereotoechus cf. S. typicus Duncan}

Plate 1, figure 1

1939. Stereotocchus typicus Duncan, Univ. Michigan, Mus. Paleontology, Contr., v. 5, p. 261, pl. 13, figs. 10-13.

Only two specimens were found in the Hamilton of New York. They agree with the qualitative characters of the Michigan holotype specimen. In addition to the characters described by Duncan (1939, p. 261) both the Michigan and New York specimens possess small intrazooecial cysts, ranging from spherical to rod shaped to irregularly globular. The cysts may be isolated or in clusters and are generally filled with brown granular material. Many of the cysts have definite walls of laminated skeletal material connected directly to the laminae of the diaphragms. A few cysts are alined in the planes of the diaphragms and the diaphragms are inflected around the cysts.

The quantitative measurements show some variation that might prove to be intraspecific if enough specimens were available for study.

Zsoecia in $2 \mathrm{~mm}$ Acanthopores per zooecium . . . . . . . . Maximum diameter of megazooecia mm . Average zooecial wall thickness. . _ do . .

Type: Figured specimen USNM 133853.

Occurrence: Centerfield limestone member of the Ludlowville shale, USNM collection $275 \mathrm{~A}$, Batavia quadrangle, New York.

\section{Genus DYOIDOPHRAgMa Duncan}

1939. Dyoidophragma Duncan, Univ. Michigan, Mus. Paleontology, Contr., vol. 5, p. 240.

\section{Type species.-Dyoidophragma typicale Duncan} 1939.

Emended definition.-Zoaria are incrusting to irregularly massive and commonly develop one or more layers of overgrowth. Monticules occur, but height and included elements are extremely variable. The neanic region is generally short and recumbent. The ephebic zone is relatively long and zooecia open perpendicularly to the surface of the zoarium. Zooecial walls are fairly uniform in thickness. Thick laminated hemiphragms are characteristic of the genus and project from the zooecial walls on the proximal side of the zooecia. Diaphragms are thin, complete, and can occur in both zooecia and mesopores. Mesopores are rare to abundant in different species; acanthopores are laminated, large and numerous.

Remarks.-Configurations of the laminae of the hemiphragms of Dyoidophragma afford evidence for the position of the lime secreting tissue of the polypides that formed the hemiphragms. Assuming parallelism of the skeletal laminae and the secreting tissue, little or no skeletal material was added from the proximal (generally lower) side of the shelflike hemiphragms (fig. 22). Rather, a hemiphragm apparently was built from its upper surface by the secreting tissue that gradually added laminae, extending each successive lamina progressively farther out into the zooecial cavity. The laminae were abruptly terminated after lapping over the end of the growing hemiphragm, forming an irregularly ridged undersurface to the hemiphragm. A few hemiphragms show a slight recurving of skeletal laminae on their proximal side, implying either a similar recurving of the secreting tissue around the ends of the hemiphragms or a very unequal addition of lime by secreting tissue located below the hemiphragms.

The positions of the diaphragms in the zooecia are irregular and seemingly independent of the hemiphragms. This apparent independence of the diaphragms, or lack of diaphragms altogether in many zooecia, leaves the position of the complete polypide unknown relative to the hemiphragms, as diaphragms are generally considered to be floors upon which the complete polypide rests.

The addition of laminae from only one side of a hemiphragm affords comparison of these structures with zooecial walls of the Trepostomata. The asymmetrical structure of the hemiphragm is similar to the structure of the half of a zooecial wall built by a single polypide. The ridged underside of the hemi- 


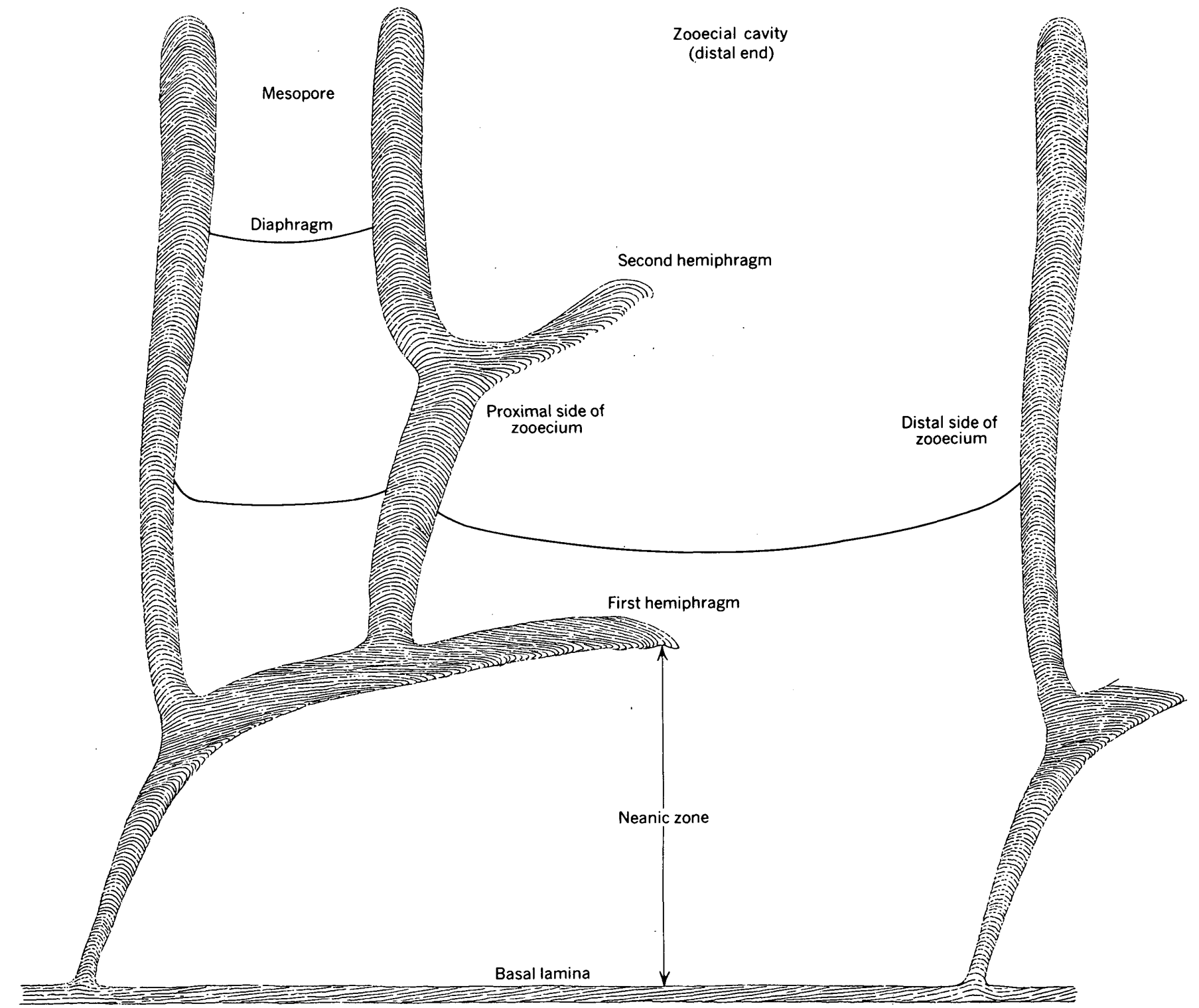

Figore 22.-Diagrammatic longitudinal section of a zooecium and mesopore of Dyoidophragma polymorphum llustrating the laminated structure of the skeleton.

phragm would correspond to the outer zooecial boundary of the zooid. If laminae were added symmetrically from both sides of the hemiphragm, the laminated structure would appear identical with the typical zooecial wall that is added to equally on both sides of the zooecial boundary by adjacent polypides. The zooecial boundary of a wall commonly is marked by terminations of laminae abutting against each other from adjacent zooecia in a ragged or irregularly serrated zone between the zooecia. This raggedness is caused by the irregularly unequal lengths of neighboring laminae and has the same appearance in longitudinal section as the irregularly ridged underside of the hemiphragms.
Dyoidophragma polymorphum Boardman, n. sp.

Plate 2, figures 1-6

Diagnosis.-Incrusting to irregularly massive species distinguished by abundant mesopores without hemiphragms; hemiphragms evenly spaced in zooecia; diaphragms irregularly spaced or absent in both zooecia and mesopores.

Description.-Zoaria are incrusting to irregularly massive. The incrusting specimens occur commonly on crinoid columnals and rarely on brachiopods, gastropods, or other bryozoans. Overgrowth is common; as many as 3 or 4 layers were developed in older colonies. Ordinarily, each layer of overgrowth displays a different growth stage. Monticules are vari- 
able in height; a few display zooecia with thickened walls and enlarged acanthopores; other monticules contain megazooecia with walls and acanthopores unmodified.

The neanic region generally can not be defined in the usual thin and thick-walled sense. The earliest zooecial wall at its junction with the basal lamina possesses the thickness and laminated structure characteristic of ephebic walls. The directional trend of the zooecial tube proximal to the earliest hemiphragm, however, is nearly parallel to the basal lamina, as in the thin-walled neanic regions of most incrusted species of the Trepostomata. The neanic zone is arbitrarily defined to include the recumbent part of the zooecium proximal to the first hemiphragm (fig. 22). A very few zooecia display single thin diaphragms within or partly within the neanic zone. The zooecial bend is abrupt, generally coincides with the distal end of the neanic zone and changes the directional trend of the zooecial tube from nearly parallel to perpendicular to the incrusted surface. In zoaria incrusting very irregular surfaces and those displaying an irregularly massive growth habit, a typical thin-walled growth may develop either in the neanic or ephebic zones. A single zoarium displays thin-walled development in one group of zooecia and not in adjacent zooecia, thus the attribute is given no taxonomic value.

In the ephebic region the zooecial walls vary in thickness from uniform to irregular within a zoarium. Some zooecial walls are sharply inflected at the point of attachment of the hemiphragms (pl. 2, fig. 1). Diaphragms in observed zooecia range from 0 to 6 and are commonly absent. Their distribution is so irregular within a zoarium that they are not. considered a measure of growth stage in this species. The first diaphragm may be connected to the first hemiphragm or occur well within the ephebic zone. The diaphragms are uniformly thin, planar to irregularly curved, and located between or connected to the hemiphragms. The hemiphragms are evenly and closely spaced on the proximal side of the zooecia, and provide a convenient measure of growth stage in this species and probably within the genus. They are planar to concentrically wrinkled and a few are known to be approximately semicircular in plan view. Probably all zooecia contain hemiphragms, but, because they originate on the proximal walls and extend about one third to one half way across the zooecial voids, the plane of a longitudinal section can not be expected to intersect hemiphragms in all zooecia. Mesopores are abundant and generally contain one to several thin diaphragms and no hemiphragms (fig. $22 ;$ pl. 2, fig. 2). A rare zooecium is limited to the ephebic zone (bottom of the zooecium is formed by the earliest hemiphragm of the adjacent zooecium) but differs from a mesopore in possessing hemiphragms and a diameter comparable to surrounding zooecia.

In tangential view, the apertures range from polygonal to subcircular. Zooecial walls are amalgamate. Mesopores are abundant but their numbers may be extremely varied in different areas of the same tangential section. The mesopores are concentrated at corners of the zooecia either singly or in pairs and in some zoaria are abundant enough to encircle a few zooecia completely. Acanthopores are large and abundant, inflect the zooecial walls; and are not restricted to the corners of the zooecia.

The following table is based on 20 sectioned fragments from 20 zoaria. Sections from 54 zoaria of D. polymorphum were examined.

\begin{tabular}{|c|c|c|}
\hline Dianhroms in onbabic "ono & Minimum & Maximum \\
\hline Diaphragms in ephebic zone & 0 & \\
\hline Zooecia in $2 \mathrm{~mm}$ & $71 / 2$ & 11 \\
\hline $\begin{array}{r}\text { Average diameter of zooecia per fragment } \\
\mathrm{mm}\end{array}$ & .17 & 22 \\
\hline Diameter of megazooecia & $\ldots \ldots$ & 30 \\
\hline Acanthopores perizooecium & .9 & 3.1 \\
\hline Mesopores per zooecium & .8 & 2. 0 \\
\hline
\end{tabular}

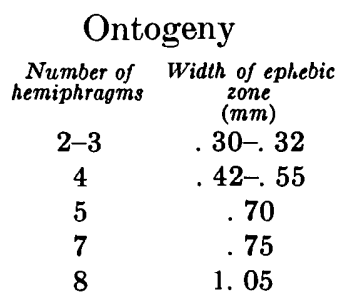

Types: Holotype USNM 133861 from USGS collection $3564-\mathrm{SD}$; figured paratypes USNM 133859, 133860, 133862133864 .

Occurence: Ludlowville shale: Centerfield limestone member, USGS 3593-SD; Wanakah shale member as used by Buehler and Tesmer (in press), USGS-SD 3502, 3511, 3515, 3518 , 3524, 3526, 3558a, 3565, USNM collections (20), 1015; King Ferry shale member of Cooper (1930), USGS 3564-SD. Moscow formation: Portland Point member of Cooper (1930), USGS 3551-SD ; Kashong member of Cooper (1930) ; USGS-SD $3500,3508,3531,3542,3552$ and 3558; Windom member, USGS-SD 3559, 3575. Localities range from Lake Erie to Cayuga Lake.

\section{Genus CaLACANTHOPORA Duncan}

1939. Calacanthopora Duncan, Univ. Michigan, Mus. Pàleontology, Contr., v. 5, p. 235.

Type species.-Calacanthopora prima Duncan 1939.

Original definition.-"Zoarium incrusting. Walls completely amalgamate, uniform in thickness. Diaphragms and mesopores absent. Acanthopores well defined, usually very large, numerous." (Duncan, 1939). 
Remarks.-The genus displays stereotoechid walls (p. 30) and resulting broadly amalgamate appearance in tangential view. The generic concept is based on a single zoarium. It is possible that the thinness of the incrusting zoarium and the lack of diaphragms reflects an astogenetically young growth stage rather than taxonomic characters of specific and generic value. The problem can be solved only by investigation of additional Traverse collections, preferably topotype specimens, not now available.

Calacanthopora? senticosa Boardman, n. sp.

Plate 1, figures 2-4

Diagnosis.-Incrusting and possibly ramose species, ramose forms with hollow axial tube supporting zooecia; diaphragms few, remote; mesopores common; acanthopores abundant, uniformly spaced in zooecial walls.

Description.-Zoaria are incrusting or ramose. Incrusting zoaria occur on crinoid columnals. Ramose forms, including the holotype specimen, possess a hollow axial tube. The wall of the tube also serves as a basal lamina for the zooecia, and it is corrugated with a regularity suggesting that the central tube was originally filled with a supporting structure possessing annulated ridges such as a crinoid stem. If a supporting structure was present during the growth of the bryozoan colony, the zoarium is more properly considered incrusting. One incrusting specimen is continuous around the disarticulated end of a segment of crinoid columnals indicating the bryozoan grew after the death and disarticulation of the crinoid. Abundant acanthopores produce a spinose texture to the external view. Monticules are unknown.

In the neanic region, the basal laminae and the zooecial walls vary considerably in thickness, even within a single fragment. The thickness of the two structures is proportional in any one zooecium. Thick neanic walls have a leptotrypellid appearance (p. 32) and a noticeable zooecial lining and sharp zooecial boundary. Distal to the zooecial bend, however, the wall structure becomes stereotoechid (p. 30) and tangential sections all have stereotoechid characteristics. In a few zooecia, the acanthopores can be followed down into the neanic region, an uncommon condition in the Trenpostomata.

In the ephebic zone, zooecial walls are relatively straight and uniform in thickness. Zooecial boundaries are not discernible; the laminae from adjacent zooecia appear to be continuous. Acanthopores begin either in the neanic zone or at the boundary between the neanic and ephebic zones. Diaphragms are few (maximum of 3 observed) and are lacking in the relatively undeveloped zoaria. If present, the diaphragms are generally widely and irregularly spaced, uniformly thin, and planar to slightly curved. Diaphragms are less common in the mesopores.

In tangential view, zooecial apertures are generally subcircular. Mesopores are very small and are normally clustered at the zooecial corners in groups of one to three. Apertures of the mesopores are subcircular to subpolygonal. Acanthopores are extremely abundant and are uniformly and closely spaced in the zooecial walls. The acanthopores are relatively large, generally causing inflection of the zooecial walls, and many possess large central tubes.

The following table is based on 5 sectioned fragments from 5 zoaria. Sections from 7 zoaria of $C$.? senticosa were examined.

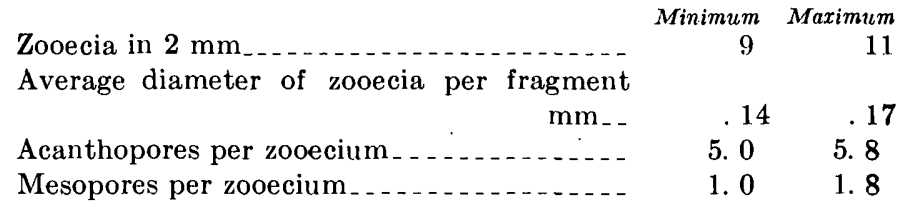

Remarks.-No described genus seems suitable for the placement of C.? senticosa. Dyscritella Girty (1911, p. 193) first described from the Fayetteville shale of the Chester series is a remote possibility and subsequent investigation of possible stratigraphically intervening species may display morphologic transition indicating phylogenetic connections.

The type species of Calacanthopora is not well enough understood to warrant expansion of the generic concept to include $C$.? senticosa without reservation. However, joint possession of stereotoechid wall structure in combination with abundant acanthopores in early growth stages, and general similarity in appearance of young incrusting zoaria of $C$.? senticosa with that of $C$. prima indicate the possibility of a generic relationship.

Types: Holotype USNM 133854, from USGS collection 3502-SD; figured paratypes 133855, 133856.

Occurrence: Wanakah shale member (as used by Buehler and Tesmer) of the Ludlowville shale, USGS 3502-SD, Buffalo quadrangle.

\section{LEIOCLEMID GROUP}

Species from the Hamilton group that display the distinctive leioclemid wall structure are limited to the genus Leioclema. The wall structure is characterized by well-defined groups of laminae in loosely or irregularly packed superposition; the laminae closely parallel the longitudinal directions of the zooecia for short but appreciable distances before curving into the zooecial boundaries (see p. 30, and fig. 10). 


\section{Genus IEIOCLEMA Ulrich}

1882. Leioclema Ulrich, Cincinnati Soc. Nat. History Jour., v. 5, pt. 1, p. 141, 154 .

1883. Thallostigma Hall, Albany Inst. Trans., v. 10, p. 154.

1890. Leioclema Ulrich, Illinois Geol. Survey, v. 8, pt. 2, p. $376,425$.

1896. Lioclema (Objective synonym) Ulrich, Zittel's Textbook of Paleontology (English ed.) p. 277.

1900. Lioclema Nickles and Bassler, U. S. Geol. Survey Bull. 173, p. 33.

1904. Lioclema Ulrich and Bassler, Smithsonian Misc. Coll., v. 47, p. 38 .

1934. Lioclema Bassler, Fossilium Catalogus, I: Animalia, Pars 67, p. 140.

1949. Leioclema Duncan, Washington Acad. Sci. Jour., v. 39, no. 4 , p. 131.

Type species.-Callopora punctata Hall, 1858.

Definition.-"Zoarium ramose, lamellar, subglobose, or incrusting; surface frequently exhibiting distinct monticules or maculae; zooecia with subcircular or irregularly petaloid apertures, separated by abundant angular mesopores, which in some species are open at the surface, in others closed; diaphragms few in the zooecia, abundant, and sometimes crowded in the mesopores; acanthopores numerous and strong in the typical species, small and inconspicuous in others." (Nickles and Bassler, 1900, p. 33).

In some species of Leioclemena (L. confertiporum) mesopores within the neanic region present a vesicular appearance strikingly similar to that of fistuliporoid bryozoans. However, these species retain the wall structure and other characters of the Trepostomata.

The following are species of Leioclema from the Hamilton group or its equivalents that were restudied or newly named.

alpenense Duncan 1939, p. 248, pl. 16, figs. 16-18

confertiporum (Hall) 1883

L. monroei (Ulrich and Bassler 1904, included in synonymy.

decipiens (Hall) 1883 (Redescribed on p. 47).

L. attenuatum Duncan 1939, included in synonymy.

L. traversense Duncan 1939, included in synonymy.

elasmaticum Boardman, n. sp.

incompositum Duncan 1939, p. 250, pl. 15, figs. 4-6 passitabulatum Duncan 1939, p. 251, pl. 16, figs. 8-10

L. microporum (Hall) 1883, p. 186 and L. segregatum (Hall) 1883, p. 186 appear to belong to Leioclema from external characters but the primary types are too small for sectioning and the specimens cannot be compared at the species level.
L. multaculeatum (Hall) 1884, p. 23, was first illustrated in Hall and Simpson (1887, pl. 59, figs. 10, 11) and appears to be a typical Leioclema. However, thin sections of the primary type (N.Y.S.M. 747) were studied and that specimen is not Leioclema. Generic identification cannot be made, however, because the sections were too fragmentary and the generic assignment of the species therefore remains in doubt.

The following Hamilton species were placed in Leioclema by Nickles and Bassler in 1900. A restudy of the primary types, however, indicates that they are fistuliporoids and do not belong in Leioclema.

Fistulipora involvens. Hall and Simpson 1887, p. 221, pl. 59, fig. 2

Thallostigma denisa Hall 1883, p. 186

T. digitata Hall 1883, p. 185

T. subtilis Hall 1883, p. 187

Leioclema confertiporum (Hall)

Plate 3, figures 1-3

1883. Thallostigma confertipora Hall, Albany Inst. Trans., v. 10, p. 184.

1887. Fistulipora confertipora (Hall), Hall and Simpson, New York State Geol. Survey, Palaeontology, v. 6, p. 211, pl. 58, figs. 1-5.

1897. Fistuliporina confertipora (Hall), Simpson, New York State Geologist Annual Rept. 14, pl. 21, flg. 13. (Plate description wrongly lists the species as coming from the lower Helderberg group, near Clarksville, N.Y.).

1900. Lioclema confertiporum (Hall), Nickles and Bassler, U. S. Geol. Survey Bull. 173, p. 303.

1904. Lioclema monroei Ulrich and Bassler, Smithsonian Misc. Coll. (Quarterly Issue), v. 47, no. 1470, p. 39, pl. 11, figs. 10-12.

Diagnosis:-A Leioclema of incrusting, irregularly massive, or subramose growth habit, distinguished by fistuliporoid-like vesicular structure of mesopores in neanic zones and strong and irregular thickening of mesopore and zooecial walls in ephebic zones.

Description.-Zoaria are incrusting, irregularly massive, and subramose. In incrusting and massive forms, layers of overgrowth are common. Individual layers are as much as $7 \mathrm{~mm}$ thick and a complete zoarium is as much as $25 \mathrm{~mm}$ high. The basal laminae of many overgrowths are laterally discontinuous within a zoarium. Beyond the areas of the overgrowths, the zooecia are continuous. However, their walls commonly change abruptly from a thickwalled ephebic development to a thin-walled neanic growth at the levels of adjacent basal laminae. The incrusting zoaria occur on crinoid columnals and fistuliporoid bryozoans.

The subramose zoaria resulted largely from a modification of the incrusting growth habit. A branch con- 
sists of a series of incrusting layers or overgrowths. These layers thicken over the end of the branch, thus, the length of the branch was increased more rapidly than the diameter and a short, thick branch was produced. New thin-walled growth without the formation of a basal lamina of an overgrowth also occurred in neanic zones following abandoned growing tips, as is more common in the ramose growth habit. Cyclic growth without a basal lamina is not common in the species however, and thus not considered to be of primary importance in branch formation in the species.

Monticules are widely spaced and low. The included zooecia have diameters comparable to intermonticular zooecia but possess strongly thickened walls. Mesopores are less numerous in the monticules than in surrounding areas. The space between the monticular zooecia is largely occupied by strongly thickened deposits of the zooecial walls. Acanthopores are more abundant within the monticules and are extremely variable in diameter, ranging from 0.01 to $0.10 \mathrm{~mm}$.

In incrusting and massive zoaria, thin-walled neanic regions extend distal to the zooecial bends for varying distances. Typically, the mesopores originate at the zooecial bend as uniserial chains of thin-walled, irregularly ovidal or spherical chambers. Several adjacent mesopores resemble the vesicular structure of fistuliporoid Bryozoa. Less commonly mesopores and zooecia do not develop thin-walled zones distal to the zooecial bends, but display thick-walled ephebic growth immediately beyond the bends.

In subramose zoaria, the neanic regions are repeatedly interrupted by closely spaced remnants of abandoned growing tips that are generally followed by basal laminae of overgrowths or less commonly by continuous but thin-walled zooecial growth. The beginning vesicular structure of mesopores is common just proximal to the abandoned growing tips giving the neanic region'a more vesicular and less tubular appearance than is common in most ramose trepostomes. Zooecial walls are also irregularly undulating, further adding to the vesicular appearance. Proximal ends of new zooecia are generally blunt and centered on walls separating parent zooecia.

The beginning of the ephebic zone in all growth forms is marked by a thickening of the zooecial walls and thick, planar, closely and regularly spaced diaphragms in the mesopores. The ephebic walls of the zooecia and mesopores are irregularly and strongly thickened. The wide variation in wall thickness is unusual for the genus and is considered a specific character. Diaphragms within the zooecia are thin; commonly they are wanting but as many as three were observed in some tubes.
In the tangential view, zooecial apertures are subelliptical to subcircular. Each zooecium is ordinarily surrounded by 1 or 2 rows of mesopores. In addition, mesopores occur in clusters of 4 or 5 between symmetrically arranged groups of four zooecia. The apertures of the mesopores are subpolygonal, rarely subcircular. Mesopores are generally smaller than the zooecia, but a few are larger and are irregularly elongate in cross section. Acanthopores are common and concentrated around zooecial apertures. They are extremely variable in diameter and have large, central tubes.

The following table is based on 9 fragments from 7 incrusting and massive zoaria of $L$. confertiporum. Sections from 8 incrusting and massive zoaria were examined.

Zooecial diaphragms . ...........

Mesopore diaphragms per $\mathrm{mm}$ ephebic zone......................

Average diameter of zooecia per fragment...............mm..

Average diameter of mesopores per fragment............mm.. Acanthopores per zooecium _..... Mesopores per zooecium_.......

\begin{tabular}{|c|c|c|}
\hline \multirow{3}{*}{$\begin{array}{l}\text { Lectotype } \\
7.9 . \\
1-3\end{array}$} & \multicolumn{2}{|c|}{$\begin{array}{l}\text { Two paratypes and four } \\
\text { identified specimens }\end{array}$} \\
\hline & Minimum & Maximum \\
\hline & 0 & 2 \\
\hline 10 & 7. 2 & 10 \\
\hline .20 & .17 & 23 \\
\hline .09 & 09 & .14 \\
\hline 2. 3 & 1. 3 & 2. 0 \\
\hline 3. 2 & 2. 6 & 4. 3 \\
\hline
\end{tabular}

Ontogeny of incrusting and massive zoaria

$\begin{array}{rr}\begin{array}{c}\text { Number of } \\ \text { diaphragms } \\ \text { in mesopores }\end{array} & \begin{array}{c}\text { Widthofephebic } \\ \text { 2one } \\ (\mathrm{mm})\end{array} \\ 5 & 0.5 \\ 8-9 & 1.0 \\ 12 & 1.2 \\ 13 & 1.5-1.8 \\ 16 & 2.1\end{array}$

The following table is based on 7 fragments from the 6 subramose zoaria of $L$. confertiporum available for study, in addition to the holotype of $L$. monroei.

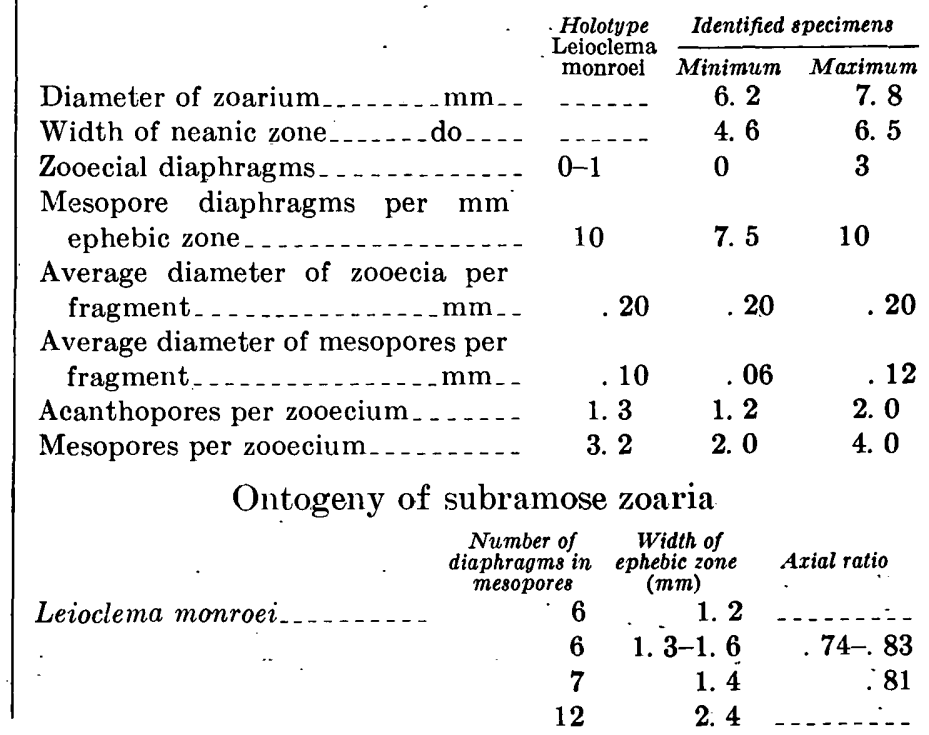


Remarlss.-The subramose growth habit is known only in the Centerfield limestone member. The incrusting and massive growth habits occur in the Wanakah shale and Tichenor limestone members. Not enough zoaria are available for study, however, to rule out the possibility of one or all three of the members containing both incrusting and subramose forms. The zooecia of both growth habits are alike in qualitative and quantitative characteristics. Incrusting overgrowths of subramose zoaria can not be distinguished from zoaria that are completely incrusting. Also, the subramose growth habit apparently arises from a slight modification of the incrusting growth habit.

Hall's syntypes of $L$. confertiporum appear to be incrusting but available fragments are so small that the lectotype could be subramose. The stratigraphic occurrence within the Hamilton group of Hall's specimens is not known. The holotype of $L$. monroei, here considered a junior subjective synonym, is subramose and its stratigraphic occurrence within the Hamilton group is also unknown.

$L$. confertiporum is readily distinguished from other species of Leioclema by the thick zooecial walls, especially in the monticules, and the vesicular appearance of the mesopores in the neanic region.

Types: Lectotype NYSM 734 (Hall and Simpson 1887, pl. 58, fig. 2) from the Hamilton group, Moscow, New York; figured specimens USNM $133865,133866$.

Occurrence: Ludlowville shale: Centerfield limestone member, USGS-SD, 3503, 3528; Wanakah shale member as used by Buehler and Tesner (in press), USGS-SD 3502, 3558a, USNM collection 1011. Localities range from Lake Erie to Seneca Lake. The locality for the holotype specimen of $L$. monroei is Hamilton group, Bethany, New York.

\section{Leloclema decipiens (Hall)}

Plate 4, flgures 1-4

1883. Thallostigma decipiens Hall, Albany Inst. Trans., v. 10 , p. 187.

1887. Fistulipora decipiens (Hall), Hall and Simpson, New York State Geol. Survey, Palaeontology, v. 6, p. 232, pl. 59, flg. 9.

1900. Lioclema decipiens (Hall), Nickles and Bassler, U. S. Geol. Survey Bull. 173, p. 303.

1939. Lioclema attenuatum Duncan, Univ. Michigan Mus. Paleontology, Contr., v. 5, p. 249, pl. 16, flgs. 13-15.

1939. Lioclema traversense Duncan, ibid., p. 252 , pl. 16, figs. $11,12$.

Diagnosis.-Zoaria thin lamellar expansions, a few incrusting; in neanic region, mesopores thin-walled and divided into elongate, angular compartments by tabular diaphragms; in ephebic zone, zooecial walls moderate and uniform in thickness.

Description.-The zoaria assume the thin lamellar expansions of the incrusting growth habit but their basal laminae most commonly rest directly on the matrix of the inclosing mudstones and siltstones. The expansions display irregularly curved and undulating contortions. A few zoaria are incrusting directly on other fossils for at least part of their area. Incrusted forms include brachiopods, corals (auloporoids and Pleurodictyum) and fistuliporoid, fenestellid and trepostomatous Bryozoa. Overgrowth is common although most zoaria show single growth cycles, or layers of mud between thin zoarial layers that cannot always be demonstrated to be continuous, so might be separate incrusting zoaria. Monticules are inconspicuous and are merely suggested by groups of zooecia with slightly thicker walls, differing concentrations of mesopores, or larger acanthopores.

In the neanic zone, zooecial tubes begin in the normal recumbent position of the incrusting growth habit. The neanic zone extends distally at least to the sharp zooecial bend and in some zooecia and mesopores it extends beyond the bend for varying distances if walls remain thin. Mesopores begin at the zooecial bends. If thin walled in the beginning, they are normally divided into elongate angular compartments by thin tabular diaphragms. The compartments appear sharply rectangular in sections. In parts or throughout some zoaria thicker walled ephebic growth follows the bends directly.

In the ephebic zone, zooecial walls are variable in thickness in different zoaria and never develop more than moderate thicknesses $(0.04 \mathrm{~mm})$. Wall thickening in a zooecium is fairly uniform. Zooecia are generally without diaphragms and no more than three were observed. Mesopores develop closely and regularly spaced diaphragms that are variable in thickness but generally thinner than surrounding mesopore and zooecial walls.

In tangential sections, zooecial apertures are subcircular to suboval. Mesopore apertures are subpolygonal to subcircular, and their average diameter is half or slightly more than half the diameter of the zooecia. Mesopores generally surround zooecia in single rows and also occur in clusters of 4 to 6 in larger, regularly spaced interzooecial areas. Acanthopores are common, and concentrated around zooecial apertures, generally causing some inflection of the walls. They are extremely variable in diameter and have large central tubes.

The following table is based on 16 fragments from 14 zoaria. Sections from 24 zoaria of $L$. decipiens werv examined. (Above figures do not include the holotype of $L$. decipiens and the holotype of $L$. traversense). 


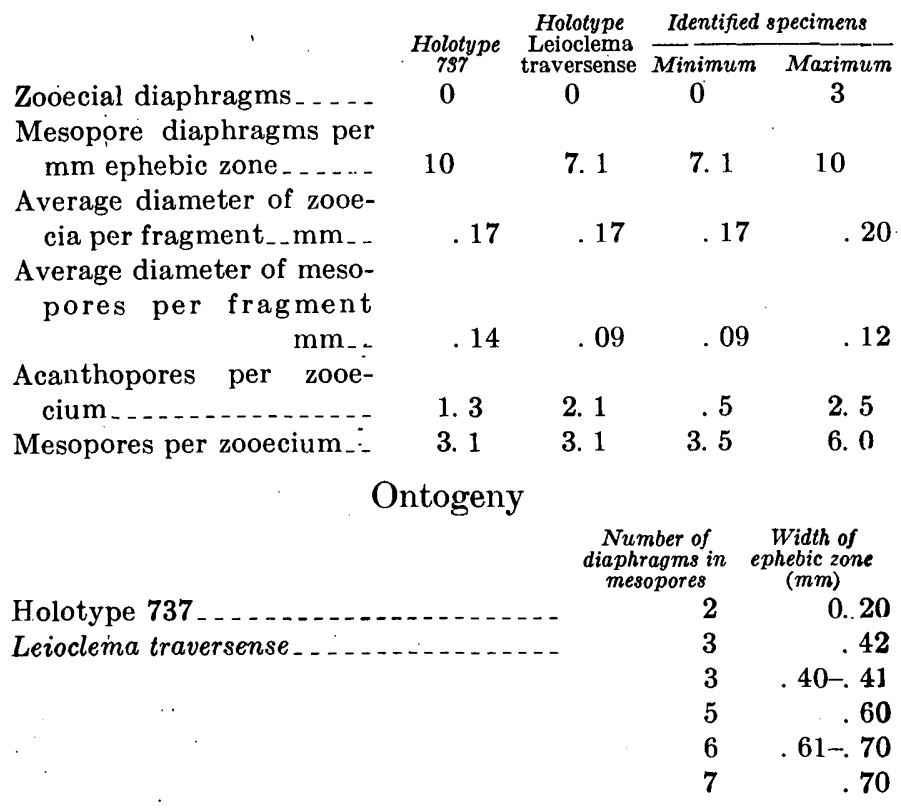

Remarks.-L. attenuatum Duncan 1939, is considered to be a young growth stage of $L$. decipiens: the holotype displaying 1 to 2 mesopore diaphragms in the ephebic zone and no important differences in the tangential section.

Zoaria that display the angular compartments of mesopores in neanic zones and other morphologic characteristics of $L$. decipiens as here described occur in two collections ( 3502 and 3558a) of the Wanakah shale with zoaria that contain vesicular mesopores and are assigned to $L$. confertiporum. Zoaria displaying transitional morphologic characteristics were not found so the species are considered distinct.

Types: Holotype NYSM 737, Hamilton group, York, New York; figured specimens USNM·133867-133869.

Occurrence: Ludlowville shale: Wanakah shale member as used by Buehler and Tesmer, USGS-SD 3502, 3511, 3516, 3518, 3558a, 3565; King Ferry shale member of Cooper (1930) USGS 3582-SD. Moscow shale: Kashong member of Cooper (1930), USGS-SD 3500, 3552, 3556, 3558. Collections range from Lake Erie to Cayuga Lake. The holotype of $L$. traversense Duncan is from the Norway Point formation, Michigan. The holotype of $L$. attenuatum Duncan is from the Potter Farm formation, Michigan.

\section{Leioclema elasmaticum Boardman, n. sp.}

Plate 4, figures 5-8

Diagnosis.-Zoaria thin lamellar expansions, basal laminae directly on rock matrix; doubtful monticules indicated by few acanthopores in isolated zooecial groups, intermonticular areas without acanthopores.

Description.-The zoaria assume the thin lamellar expansions of the incrusting growth habit but their basal laminae rest directly on the inclosing mudstones and siltstones. The expansions display irregularly curved and undulating contortions. Overgrowth is fairly common although most zoaria consist of single growth cycles or contain layers of mud between thin expansions. The presence of monticules is uncertain and is suggested only by small isolated groups of zooecia and mesopores that display acanthopores. Acanthopores are completely lacking or very rare between the questionable monticules.

The neanic zone begins with the thin laminated walls of the recumbent zooecia branching from the basal laminae, as in the normal incrusting growth habit. The neanic zone extends at least to the sharp zooecial bend and in a few zooecia and mesopores extends beyond the bend for short distances if walls remain thin. Mesopores begin at the zooecial bends.

The few mesopores that start with thin walls develop as many as three irregular chambers. Most mesopores start with thickened walls and closely and evenly spaced diaphragms, marking the beginning of the ephebic zone. The thickness of the mesopore diaphragms varies, generally in proportion to wall thickness. In the ephebic zone there is much variation in the thickness of zooecial walls in different zoaria or in parts of the same zoarium. However, the extremes are linked by forms in which the walls are of intermediate thicknesses. The ephebic wall thickness of individual zooecia and mesopores, however, is fairly uniform. Diaphragms in the zooecia are thin and uncommon; no more than one occurs in a zooecium in the specimens studied.

In tangential sections, zooecial apertures are subcircular to suboval. The apertures of the mesopores are normally subpolygonal, rarely subcircular, and are generally smaller than the zooecial apertures. A few mesopores are larger than the zooecia, and these are commonly irregularly elongate in cross section. Mesopores generally surround zooecia in single rows and also occur in clusters of 4 to 8 in larger, regularly distributed interzooecial spaces. Acanthopores normally do not occur; those found are in concentrated areas that might represent monticules and are of small to medium size.

The following table is based on 12 fragments from the 11 zoaria of $L$. elasmaticum available for study.

\begin{tabular}{|c|c|c|}
\hline & Minimum & Maximum \\
\hline $\begin{array}{l}\text { Mesopore diaphragms per } \mathrm{mm} \text { ephebic zone } \\
\text { Average diameter of zooecia per fragment }\end{array}$ & 6.8 & 8. 7 \\
\hline Average diameter mesopores per fragment & .17 & .20 \\
\hline Mesopores per zooecium & $\begin{array}{l}.09 \\
3.4\end{array}$ & $\begin{array}{l}.14 \\
5.7\end{array}$ \\
\hline
\end{tabular}




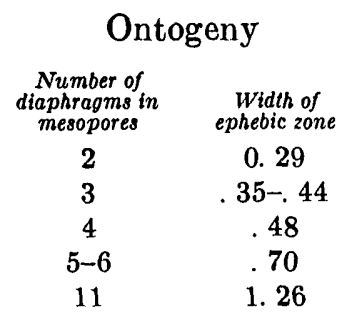

Remarks.-The restriction of acanthopores to questionable monticules that are otherwise undifferentiated from intermonticular areas distinguishes $L$. elasmaticum from all other species of Leioclema in the Hamilton group and the Traverse group of Michigan.

Types: Holotype USNM 133870 from USGS collection 3559-SD ; flgured paratypes USNM 133871-133873.

Occurrence: Moscow shale: Windom member, USGS-SD $3548,3553,3559$. Collections range from the Genesee Valley to Seneca Lake.

\section{TRACHYTOECHID GROUP}

Genera from the Hamilton group that display zooecial wall structure similar to that of the genus Trachytoechus Duncan, are placed together. The zooecial wall laminae of the included genera parallel the longitudinal direction of the zooecia for appreciable distances before curving distally to the zooecial boundaries. Zooecial walls contain mural lacunae and the thin walls of neanic zones are crenulated. (See p. 31 and figure 11).

\section{Genus TRACHYTOECHUS Duncan}

1.939. Trachytocchus Duncan, Univ. Michigan, Mus. Paleontology, Contr., v. 5, p. 261.

Type species.-Trachytoechus typicus Duncan 1939. Emended definition.-Zoaria are massive, incrusting, and subramose. Groups of larger zooecia are characteristic but are not elevated above the zoarial surface in some species. In the ephebic region, zooecial walls normally range from flexuous to crenulated. Diaphragms are uniformly thin, complete, and planar to curved. Heterophragms are characteristic of the genus and are curved projections of laminated material originating in the zooecial walls and projecting into the zooecial voids. They are subcircular in plan view and are normally concave in the proximal direction of the zooecia. Margins of the heterophragms are smooth or corrugated. In tangential view, the walls are amalgamate and commonly display mural lacunae that are either uniformly distributed, or clustered to appear as small granular acanthopores. The zooecial walls may present an overall granular appearance if the lacunae are filled with opaque material. In some species the lacunae are rare. Acanthopores are generally large and laminated. Mesopores are rare.
Remarks.-Cyphotrypa expanda Ulrich and Bassler (1923, p. 407, pl. 13, figs. 5-9) and Stenopora? incrustans Ulrich and Bassler (1913 a, p. 275, pl. 42, figs. $11-16$; pl. 44, fig. 6 ) possess trachytoechid wall structure and typical heterophragms and are here reassigned to Trachytoechus. T. expandus extends the known stratigraphic range of Trachytoechus downward to the Tonoloway limestone of Late Silurian age. The holotype section of Eostenopora? villosa Duncan (1939, p. 247, pl. 11, figs. 1, 2; pl. 12, fig. 15) displays typical trachtoechid wall structure, large acanthopores, and a very few heterophragms. The holotype specimen of E.? villosa comes from the same collection (Bell shale, locality 38) as Trachytoechus. typicus Duncan (1939, p. 263, pl. 13, figs. 1-6) and differs morphologically only in having fewer heterophragms and a younger growth stage. Assuming that the growth stage of the holotype specimen of E.? villosa is not far enough advanced to develop many heterophragms (generally concentrated in ephebic zones) $E . q$ villosa is here placed in the synonymy of $T$. typicus. Eostenopora primiformis Duncan (1939, p. 245, pl. 12, figs. $9-10)$ is considered a young growth stage and is placed in the synonymy of Trachytoechus romingeri Duncan (1939, p. 262, pl. 13, figs. 7-9).

The following species have been restudied and are considered to be species of Trachytoechus.

expandus (Ulrich and Bassler) 1923, Tonoloway limestone, West Virginia.

howelli Fritz 1951, p. 28, 29 ; pl. 1, figs. 1, 2; pl. 2, fig. 1. New Scotland limestone, New York.

incrustans (Ulrich and Bassler) 1913, Keyser limestone member of Helderberg limestone, Maryland.

moniliformis Fritz 1944b, p. 36, 37, pl. 1, flgs. 14, Gaspe sandstone, Quebec.

monticulatus (Hall) 1879, Helderberg group, New York. Reassigned to Trachytoechus by Fritz, 1951.

romingeri Duncan 1939, probably from the Genshaw formation, Michigan. Eostenopora primiformis Duncan, 1939, included in synonymy. Dock Street clay, Michigan.

typicus Duncan 1939, Bell shale, Michigan. Eostenopora? villosa Duncan 1939, included in synonymy.

variacellus (Hall) 1883 Centerfield limestone member of the Ludlowville shale, New York.

\section{Trachytoechus variacellus (Hall)}

Plate 5, figures 1-3

1883. Paleschara variacella Hall, Albany Inst. Trans., v. 10, p. 179.

1884. Paleschara variacella Hall, New York State Geologists Annual Rept. for 1883 , p. 6 .

Diagnosis.-Irregularly hemispherical Trachytoechus; megazooecia extremely large in diameter; , large acanthopores with abrupt changes in diameter to form club-shaped segments in longitudinal section; generally 
few mural lacunae; heterophragms rare, few corrugated.

Description.-Zoaria begin as incrusting forms that developed into irregularly hemispherical to subspherical masses as much as $9 \mathrm{~cm}$ in height and $15 \mathrm{~cm}$ in diameter. Internally, the zoaria display patchy and irregularly spaced overgrowths that form superim: posed layers. Many basal laminae of the overgrowths do not extend throughout a zoarium but are discontinuous. The margins of the restricted laminae abut against adjacent uninterrupted zooecia. Some patchy overgrowths thicken markedly and produce bulbous protuberances on the main zoarium. Monticules are either very low or without surface expression. Included megazooecia are extremely large in cross section (as much as three times larger than intermonticular zooecia) and display little wall thickening. Acanthopores are unmodified in the monticules.

Neanic and ephebic zones are not clearly delimited. Zooecia begin by budding from the normal basal lamina and are in a recumbent position. Distal to the zooecial bends, zooecial tubes are extremely long and show alternations of slightly thicker walled growth with more closely spaced diaphragms and a relative concentration of heterophragms, and thin-walled growth showing widely spaced diaphragms and few if any heterophragms. This thin- and thick-walled growth occurs in zones approximately parallel to the surface of the zoarium and affects varying numbers of zooecia. The zooecial walls range from straight, to undulate, to crenulate within a zoarium. Zooecial wall laminae begin by paralleling the longitudinal direction of the zooecia without forming a distinct zooecial lining. The zone of curved laminae is relatively broad. A poorly defined zooecial boundary meanders irregularly throughout the zone of curved laminae. Zooecial diaphragms are very thin, planar to slightly curved, and irregularly spaced. Diaphragms of the megazooecia are more strongly curved and are commonly cystoidal. Granular deposits of pyrite are commonly associated with diaphragms in both the normal zooecia and megazooecia in many zoaria (pl. 5, fig. 2b). Acanthopores are long and club-shaped in longitudinal section and regularly decrease their diameters abruptly (pl. 5, fig. 3b) producing transverse planes of discontinuity that commonly fracture in thin sections. Heterophragms are generally few but may be abundant locally in zones of thickened zooecial walls. The heterophragms are rarely corrugated.

In tangential section, the zooecial apertures are polygonal to subpolygonal and generally equidimensional. The megazooecial apertures are more elongated in cross section. Mesopores are very rare throughout a zoarium. Zooecial walls are amalgamate, laminated, and mural lacunae are uncommon. Acanthopores are large and are always located at the corners of zooecia. Their outer boundaries are subrectangular or subtriangular, and the acanthopores have large central tubes that are commonly filled with laminated material.

The following table is based on 17 fragments from 13 zoaria. Sections from 18 zoaria of $T$. variacellus were examined.

Diaphragms per $5 \mathrm{~mm}$ ephebic zone. Zooecia in $2 \mathrm{~mm}$

Average diameter of zooecia per

fragment. ............... mm . .

Maximum diameter of megazooecia

per fragment........... mm . Acanthopores per zooecium.....

\begin{tabular}{rrr}
$\begin{array}{c}\text { Holotype } \\
827\end{array}$ & \multicolumn{2}{c}{ Identified specimens } \\
& 9 & 21 \\
6 & 5 & $61 / 2$ \\
& & \\
.34 & .29 & .38 \\
& & \\
.72 & .60 & .90 \\
.12 & .10 & .44
\end{tabular}

Remarks.-T. variacellus can be distinguished immediately from other described species of Trachytoechus by the large club-shaped acanthopores.

Types: Holotype NYSM no. 827, Hamilton group, New York ; figured specimens USNM 133874, 133875.

Occurrence: Ludlowville shale: Centerfield limestone member, USGS-SD 3503, 3539, 3547a, 3561, 3571. Collections range from the Batavia quadrangle to Cayuga Lake.

\section{Genus ERIDOTRYPELIA Duncan}

1939. Eridotrypella Duncan, Univ. Michigan, Mus. Paleontology, Contr., v. 5, p. 210.

T'ype species.-Batostomella obliqua Ulrich 1890.

Original definition.--"Zoarium ramose. Wall structure heterotrypid-amalgamate; transverse rows of granules well defined. Walls thin, usually crenulated in immature region, gradually thickened from beginning of mature zone to surface. Zooecia oblique, slightly bent toward surface in mature zone. Diaphragms absent in immature zone, several closely arranged in early mature zone of each zooecium, usually absent near periphery. Mesopores absent. Acanthopores granular." (Duncan, 1939).

\section{Eridotrypella sp.}

Plate 1, fig. 5

A single, partly crushed fragment of a ramose zoarium was recovered from collection 3553 in the Windom member of the Moscow shale on Menteth Creek, Canandaigua Lake. This specimen is the only known occurrence of the genus in the New York Hamilton group. The scarcity of the genus in New York is in marked contrast to its prolific abundance in the Traverse group of the Michigan basin. The specimen is too poorly preserved for comparison but does seem to differ from Michigan species by display- 
ing only one diaphragm in an ephebic zone that is comparable in width with ephebic zones of Michigan forms containing 3 to 5 diaphragms.

Type: Figured specimen USNM 133857.

\section{LEPTOTRYPELIID GROUP}

Genera from the Hamilton group that display zooecial wall structures similar to that of the genus Leptotrypella Vinassa de Regny, are placed together. The wall structure is characterized by a zooecial lining. and a zone of curved laminae. The zooecial lining extends distally for considerable distances and commonly can be distinguished as a layer of lighter shaded, laminae in thin section. Laminae of the lining either lose their identity distally or can be traced outward into the zone of curved laminae. The curved laminae are generally darker and intersect the zooecial boundary at right angles. (See p. 32 and fig. 12).

\section{Genus LEPTOTRYPELLA Vinassa de Regny}

1920. Leptotrypella Vinassa de Regny, Atti. Soc. italiana sci. nat., v. 59, p. 222.

1939. Leptotrypella Duncan, Univ. Michigan, Mus. Paleontology, Contr., v. 5, p. 223.

Type species.-Chaetetes barrandi Nicholson 1874.

Emended definition.-Zoaria are ramose, subramose, incrusting, or a combination of ramose and incrusting habits. Conspecific overgrowth is common. Monticules are present and normally include megazooecia, mesopores, and enlarged acanthopores. In most species, a zooecial lining can be distinguished, and the laminae parallel the zooecia for a considerable distance in all species. Diaphragms are complete; cystoidal diaphragms vary in number but are common in most species, and compound diaphragms occur in only a few species (p. 62). Mural spines are known in about half of the species and are extremely variable in numbers within several species and typically rare or common in others. Spherical intrazooecial cysts are variable in concentration but are typical of the genus. In tangential view, zooecial boundaries are polygonal. Zooecial walls are generally amalgamate, but a few species are narrowly amalgamate to integrate. Intermonticular mesopores are scattered and few, but in rare zoaria of a few species they are equal in number to the zooecia. Acanthopores are laminated, typically numerous, but nearly absent in a few species.

Remarks.-Leptotrypella solitaria Fritz (1944, Jour. Paleontology, v. 18 , no. 1 , p. 36 , pl. 12 , figs. 10 , 16) is not referable to Leptotrypella as defined here. because of the presence of strong irregular beading in the zooecial walls. The species was based on one small fragment that does not adequately display the wall structure, although it appears to be atactotoechid. Nor is Leptotrypella cavernosa Fritz (1944, Jour. Paleontology, v. 18 , no. 1 , p. 37 , pl. 12 , figs. 6,13 ) referable to Leptotrypella. This species has a definite atactotoechid wall and the type specimen is apparently a young growth stage that shows no generic characters. Holotype slides of both species were examined for this paper.

\section{Subgenus LEPTOTRYPELLA Vinassa de Regny emend. Boardman}

Type species.-Chaetetes barrandi Nicholson 1874. Definition.-The subgenus includes those species of Leptotrypella that do not contain compound diaphragms. Characteristically, the diaphragms are simple, thin, planar to slightly curved, and evenly spaced. Cystoidal diaphragms range in abundance from very rare to common. Zooecial walls are typically amalgamate; narrowly amalgamate to integrate appearances are generally limited to scattered zooecia or monticular zooecia.

Remarks.-The nominate subgenus is considered to include the main, conservative lineages of the genus. L. (Leptotrypella) is longer in stratigraphic range, wider in geographic range (fig. 4) and greater in number of species, than L. (Pyonobasis) (p. 62) the other subgenus of Leptotrypella.

Stenoporella? devonica Duncan (1939, p. 259, pl. 14, figs. 9-10) and Cyphotrypa? unica Duncan (1939, p. 201, pl. 5, figs. 11-14) are reassigned to L. (Leptotrypella) because of wall structure and diaphragms. Eridotrypella brevis Duncan (1939, p. 211, pl. 5, figs. 15-16) is considered a young growth stage of Leptotrypella ohioensis (Stewart) (1927, p. 29, pl. 2, figs. 7-10) and is referred to the synonymy of that species. Leptotrypella undans Duncan (1939, p. 231, pl. 10, figs. 4-6) is considered a young growth stage of Leptotrypella aequabilis Duncan (1939, p. 224, pl. 9, figs. 6-7) and is placed in the synonymy of that species.

The species now assigned to L. (Leptotrypella) are:

aequabilis Duncan 1939.

L. undans Duncan 1939, included in synonymy.

amplectens (Grabau) 1899 (Redescribed on p. 60).

Monticulipora? marylandensis Ulrich and Bassler 1913, included in synonymy.

asterica Boardman, $\mathrm{n}$. sp.

barrandi (Nicholson) 1874 (Redescribed on p. 53).

devonica (Duncan) 1939.

furcata (Hall) 1877 (part) (Redescribed on p. 59).

gemmata Duncan 1939, p. 225, pl. 10, figs. 7-8.

kwangsiensis Yang, 1954 , p. 223 , pl. 2 , fig. 5 ; pl. 3, fig. 5.

magninodosa Duncan 1939, p. 226, pl. 9, figs. 8-9.

magniporta Boardman, n. sp. 
mesostena Boardman, n. sp.

mesostena mesostena Boardman, $\mathrm{n}$. subsp.

mesostena provecta Boardman, $\mathrm{n}$. subsp.

moniliformis (Nicholson) 1874, p. 57, pl. 4, figs. 7a, 7b.

multitecta Boardman, n. sp.

ohioensis (Stewart) 1927.

Eridotrypella brevis Duncan 1939, included in synonymy. parva Duncan 1939, p. 229, pl.9, figs. 4-5.

pellucida Duncan 1939, p. 230, pl. 10, figs. 9-10.

unica (Duncan) 1939.
Inferred phylogenetic lineages in L. (Leptotrypella).-The proposed L. mesostena-multitecta lineage (see p. 56) includes the intervening subspecies, $L$. mesostena provecta (fig. 23). Qualitatively, the $L$. mesostena-multitecta lineage displays the loss of fine crenulations in the neanic regions, a change of from 3-4 to 2-3 diaphragms with a lessening of the constriction of the zooecial tubes in that zone in the

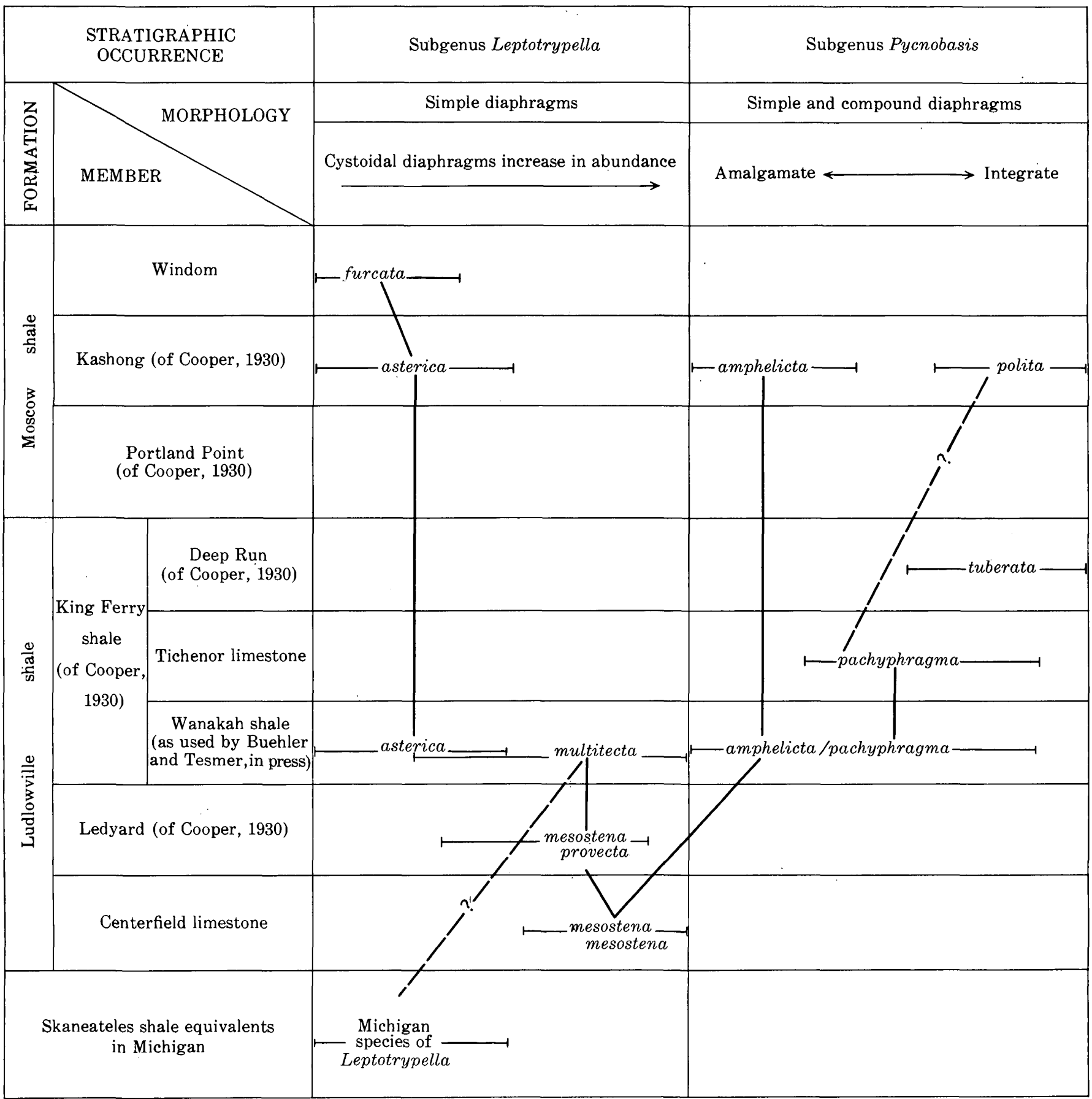

Figure 23.-Possible phylogenetic relationships of some of the species of the genus Leptotrypella. 
early ephebic zone proximal to the zooecial bend, flattening of the zooecial bend, widening of the zones of curved laminae, and the change from a generally integrate to generally amalgamate appearance in tangential sections. Quantitatively, the diameters of the neanic regions become generally larger upwards in the lineage (see table below), making the axial ratios larger for corresponding growth stages (fig. 24). A very few specimens of L. multitecta contain some zooecia with the constriction in zooecial diameter just proximal to a sharp zooecial bend, giving the appearance of $L$. mesostena and further substantiating the proposed phylogenetic relationship.

Species of Leptotrypella and their neanic diameters, arranged in stratigraphic order.

\begin{tabular}{|c|c|c|c|c|}
\hline \multicolumn{3}{|c|}{ Stratigraphic position } & \multirow{2}{*}{$\begin{array}{c}\begin{array}{c}\text { Species of } \\
\text { Leptotrypella }\end{array} \\
\text { L. multitecta } \\
\\
\begin{array}{c}\text { L. mesostena } \\
\text { provecta }\end{array} \\
\text { L. mesostena } \\
\text { mesostena }\end{array}$} & \multirow{2}{*}{$\begin{array}{l}\begin{array}{c}\text { Arithmetic mean of } \\
\text { neanic diameters }(\mathrm{mm})\end{array} \\
4.4(31 \text { zoaria }) \\
3.5(5 \text { zoaria }) \\
2.4(23 \text { zoaria })\end{array}$} \\
\hline 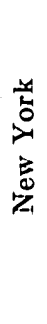 & 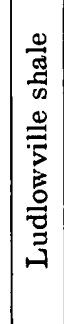 & $\begin{array}{l}\text { Wanakah shale } \\
\text { member as } \\
\text { used by } \\
\text { Buehler and } \\
\text { Tesmer } \\
\text { Led vard } \\
\text { member of } \\
\text { Cooper (1930) } \\
\text { Centerfield } \\
\text { limestone } \\
\text { member }\end{array}$ & & \\
\hline 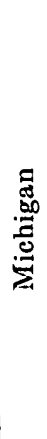 & 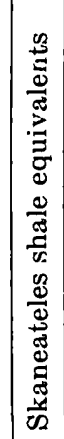 & $\begin{array}{l}\text { Dock Street } \\
\text { clay of } \\
\text { Grabau (1902) } \\
\text { Genshaw } \\
\text { formation } \\
\text { Ferron Point } \\
\text { formation } \\
\text { Bell shale }\end{array}$ & $\begin{array}{l}\text { L. monili- } \\
\text { formis } \\
\text { L. magnino- } \\
\text { dosa } \\
\text { L. aequobilis } \\
\text { L. pellucida } \\
\text { L. ohioensis } \\
\text { L. devonica } \\
\text { L. gemmata }\end{array}$ & $\begin{array}{l}\text { Neanic diameter } \\
\quad(\mathrm{mm}) \text { of } \\
\text { holotype } \\
\text { specimens } \\
2.9 \\
2.0 \\
2.0 \text { and } 2.3 \\
5.1 \\
2.8 \text { and } 3.0 \\
2.6 \\
1.4\end{array}$ \\
\hline
\end{tabular}

Another possibility for the lineage or plexus that gave rise to $L$. multitecta is suggested by the study of the holotype sections of the species of Leptotrypella described by Duncan (1939) from the Traverse group of Michigan. All of the Traverse species came from formations now considered equivalent to the New York Skaneateles shale (Cooper and others, 1942). Assuming that this time-rock correlation is correct, and that there was at least an intermittent connection between the Michigan basin and the New York area, the Traverse species could have been forebearers of $L$. multitecta. Qualitatively, there is little difference between $L$. multitecta from New York (p. 57) and L. devonica, $L$. magninodosa, and especially $L$. aequabilis from the Traverse group. Measurements of neanic diameters (table, p. 53) in the single holotype sections for each Traverse species suggests that the diameters were generally small in these older forms and increased with time to the L. multitecta level. This suggested increase in neanic diameters is consistent with the trend found in the L. mesostena-multitecta lineage proposed above. Also, an evolutionary level probably more primitive (again on the basis of the trend found in L. mesostenamultitecta) than L. multitecta is indicated for the Traverse species by a plot of their axial ratios against the number of diaphragms (fig. 24). The scatter diagram indicates that the Traverse species are at about the same evolutionary level as $L$. mesostena mesostena and L. mesostena provecta. L. pellucida, a Traverse species, is an exception in these generalizations but could belong to another lineage. If the Traverse species do constitute the lineage leading to $L$. multitecta, $L$. mesostena mesostena and $L$. mesostena provecta probably are not intermediate subspecies, due to their qualitative characteristics that are not intermediate between the Traverse species and L. multitecta. A detailed study of a large number of specimens in the Michigan Traverse group will be necessary before these evolutionary and phylogenetic relationships are clarified.

L. (Leptotrypella) asterica (p. 58) appears to be directly related to L. (Leptotrypella) furcata (p. 59). Evidence for the lineage is found in the similarity of diaphragms, cysts, and zoarial size. Morphologic changes in the lineage include a widening of the zone of curved laminae and a decrease in the thickness of the zooecial lining, trends also present in the $L$. mesostena-multitecta lineage. The development of more crenulate walls in the younger $L$. furcata is a reversal of the trend of a decrease in crenulations in the L. mesostena-multitecta lineage. No appreciable differences in neanic diameters and axial ratios occur in the $L$. asterica-furcata lineage.

\section{Leptotrypella barrandi (Nicholson)}

Plate 8 , figures 1,2

1874. Chaetetes barrandi Nicholson, Geol. Mag., dec. II of new series, v. 1 , p. 57 , pl. 4 , fig. 7 c.

1881. Monticulipora (Heterotrypa) barrandi (Nicholson), Genus Monticulipora p. 139, pl. 1, figs. 2-2d.

1882. Amplexopora barrandi (Nicholson) Ulrich, Cincinnati Soc. Nat. History Jour., v. 5, p. 255.

1920. Leptotrypella barrandei (Nicholson) Vinassa de Regny, Atti Soc. italiana sci. nat., v. 59, p. 222. 


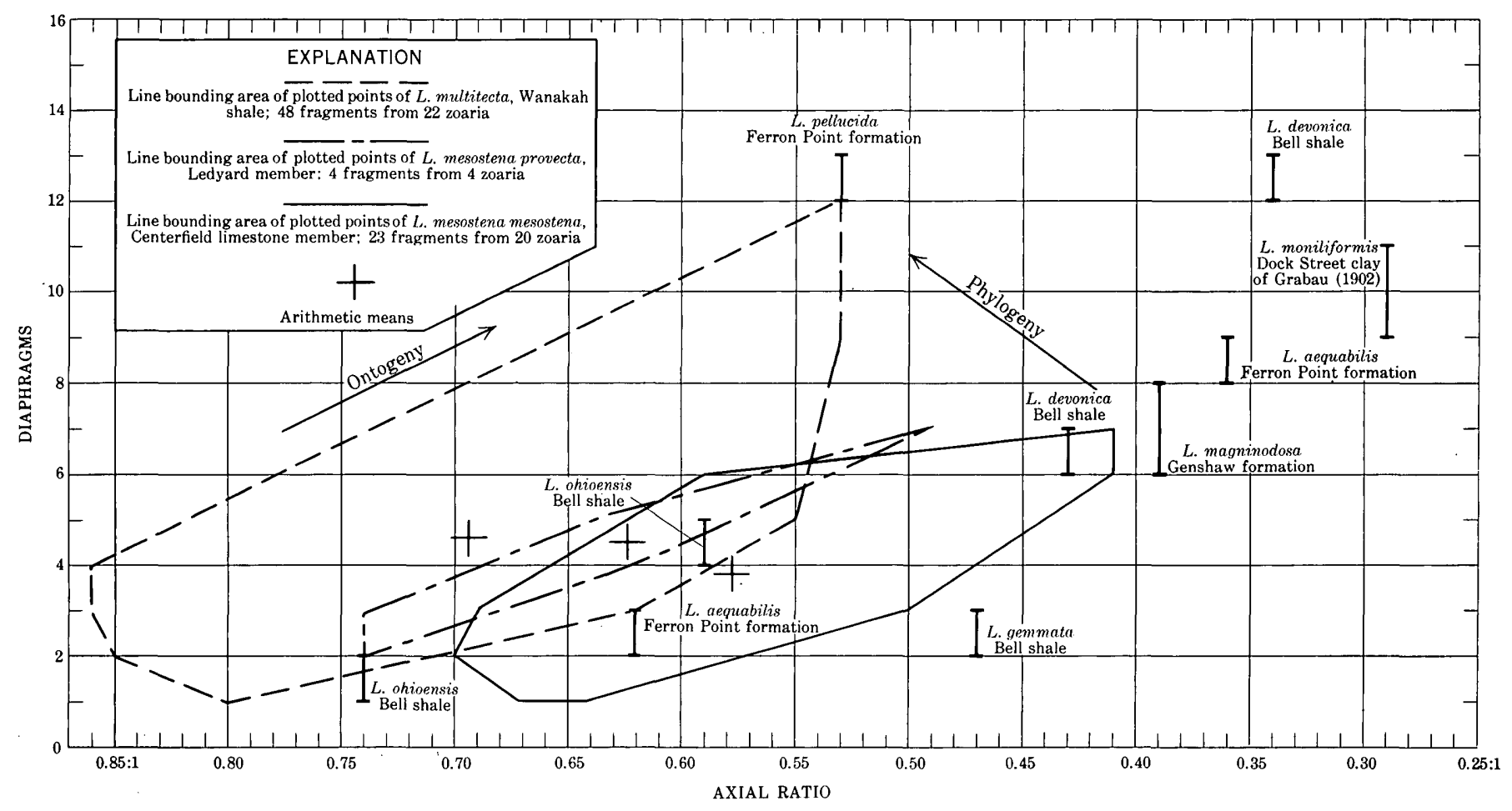

Figure 24.-Peripheral scatter diagram of the $L$. (Leptotrypella) mesostena to multitecta lineage and individual measurements of the holotype sections of species of Leptotrypella described by Duncan (1939) from the Traverse group of Michigan.

Description.-Zoaria are ramose and conspecific overgrowth is probably common as the two available specimens (see remarks below) show remnants of abandoned growing tips covered by an incrusting overgrowth that gives rise to a branch in the distal direction. Monticules are not adequately displayed in the two sections.

In the neanic region, the zooecial walls are fairly straight and undeviating. In the early ephebic zone, the zooecial bend is flat and poorly defined and the zooecia are not constricted in diameter as in L. mesostena. In the ephebic region, the zone of curved laminae is broad and lighter in color than the thin zooecial lining. The zooecial boundary is poorly defined, most laminae from adjacent zooecia merging without apparent break. The diaphragms are simple, thin, planar to slightly curved, and fairly evenly spaced. Cystoidal diaphragms and cysts are rare, mural spines and cysts are unknown.

In the tangential section, the zooecial apertures are polygonal to subcircular. The walls are amalgamate to narrowly amalgamate and a few zooecia appear integrate. Mesopores are few and irregularly distributed. Acanthopores are unusually scarce for the genus and are small, causing almost no inflection in the zooecial walls.
Diameter of zoarium . ................

Width of neanic zone................

Zooecia in $2 \mathrm{~mm}$

Average diameter of zooecia per fragment

$$
\mathrm{mm} \text {.. . . } 23
$$

Acanthopores per zooecium _........... . . 3

Mesopores per zooecium ............ Rare

\begin{tabular}{|c|c|c|c|}
\hline \multicolumn{4}{|c|}{ Ontogeny } \\
\hline Slide & $\begin{array}{c}\text { Number of } \\
\text { diaphragms }\end{array}$ & $\begin{array}{c}\text { Width of } \\
\text { ephebic zone } \\
(m m)\end{array}$ & Axial ratio \\
\hline - & $5-7$ & 2. 6 & .41 \\
\hline 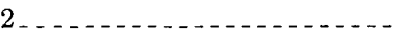 & $6-8$ & 3. 7 & .40 \\
\hline
\end{tabular}

Remarks.-The whereabouts of the holotype of $L$. barrandi is not known. Thin-sections of two frag. ments labeled $L$. barrandi (Nicholson) 1874, are available for study in the U. S. National Museum. One of them (USNM 26588) was used in the emended definition by Duncan (1939, p. 223). Both sections are from the Widder formation, Thedford, Ontario. Nicholson's original description $(1874 a$, p. 57,58$)$ gives the locality and stratigraphic position as the Hamilton group at Widder, Township of Bosanquet. The town of Widder has nearly disappeared and the name is not now in use. The center of Widder was just over a mile east of the present center of the town of Thedford. The sections labeled Thedford in the U.S. 
National Museum may be topotypes as nothing more specific than the town names is given in both the original description and the sections in the museum.

According to Nicholson's original description the diameters of the branches range from 2 to 5 lines (approximately 4 to $10 \mathrm{~mm}$ ). Nicholson describes the monticules as not forming distinct eminences, "But here and there are groups of corallites slightly larger than the ordinary one, and separated by intervals of about a line and a half" (3 mm). The one characteristic reported by Nicholson in 1874 that does not agree with the National Museum specimens is the number of zooecia in $2 \mathrm{~mm}$. Nicholson reported, "Four to five calices in the space of one line" (2.12 $\mathrm{mm}$ ). Nicholson's count is smaller than is normal for the genus and may have been taken through a monticule. Nicholson's original illustration is of no value in taxonomic interpretation.

In 1881 Nicholson added to the concept of the species by reporting that, "Small thick-walled hollow tubes (acanthopores) are occasionally developed at the angles of junction of the normal corallites." Also, he describes the diaphragms as complete and horizontal and the zooecial walls as amalgamated. The drawings of the tangential view of $L$. barrandi (1881, pl. 1, figs. $2 b, 2 c)$ are adequate in detail and agree with the museum specimens in general appearance and in the unusual scarcity and small size of the acanthopores. Nicholson's vertical view (pl. 1, fig. 2d) is apparently of a poorly oriented section and is of little help.

$L$. barrandi is most nearly like $L$. multitecta (p. 57) among the species from the New York Hamilton group. The type species differs from $L$. multitecta mainly in the scarcity and small size of its acanthopores, the straightness of its zooecial walls, the smaller neanic diameter, and smaller axial ratio for equivalent growth stages.

Types: Figured specimens USNM 26588, 133888.

Leptotrypella (Leptotrypella) mesostena Boardman, n. sp. Plate 6, figures 1-8

Diagnosis.-Polytypic species of small ramose zoaria (maximum observed diameter of branches $6.8 \mathrm{~mm}$ ) characterized by a constriction of zooecial diameters and generally 3 to 4 diaphragms in the early ephebic zone just proximal to the distinctively sharp zooecial bends; zone of curved laminae narrow for genus, many zooecia integrate as a result.

Remarks.-Two chronological subspecies are recognized within $L$. mesostena, $L$. mesostena mesostena from the Centerfield limestone member and $L$. mesostena provecta from the overlying Ledyard member.
The qualitative and quantitative morphologic differences between the subspecies are in part overlapping These transistional morphologic differences continued to develop (see p. 56) and appear more pronounced in a still younger form that also contains new characteristics, L. multitecta (p. 57) of the Wanakah shale member. This sequence of three forms connected by morphologic trends is interpreted as a phylogenetic lineage (see p. 52).

L. mesostena can be distinguished from other species of Leptotrypella in the Traverse group of Michigan and in the Hamilton group by the character of the early ephebic zone and the sharp zooecial bends.

Type: Holotype USNM 133878 from USGS collection 3503-SD.

Occurrence: Centerfield limestone member and Ledyard member (of Cooper, 1930) of the Ludlowville shale from the Batavia quadrangle to Cayuga Lake. (For complete listing of collection numbers see p. 56, 57).

\section{Leptotrypella (Leptotrypella) mesostena mesostena Boardman, n. subsp.}

Plate 6, figures 1-6

Diagnosis.-Small ramose subspecies distinguished by crenulate to undulating zooecial walls in the neanic region, narrow zone of curved laminae, correspondingly thick zooecial lining, consistently smaller axial ratios $(0.41: 1$ to $0.70: 1)$ for corresponding growth stages ( 7 and 2 diaphragms respectively) than related forms higher in the Hamilton group, integrate to narrowly amalgamate appearance in tangential sections.

Description.-Zoaria of the nominate subspecies are small and ramose. Overgrowth is patchy and rarely more than one layer is present. Monticules are low and consist of megazooecia with irregular cross sections and slightly thickened walls, a few irregularly distributed mesopores, and enlarged acanthopores.

In the neanic regions, the zooecial walls are irregularly undulating to crenulate.

In the early ephebic zone proximal to the zooecial bend, zooecia are nearly parallel to the surface of the branch and are constricted in- diameter. Also, zooecia of more advanced growth stages generally contain 3 to 4 diaphragms proximal to the zooecial bend. The zooecial bend is abrupt and well defined. Zooecial walls display generally thick linings. The zone of curved laminae is narrow. Mural spines are common to rare and are concentrated near the zooecial bend. Cysts are rare. Diaphragms are simple, generally thin, regularly spaced and planar to slightly curved. Thin cystoidal diaphragms and thick planar diaphragms are fairly common. A rare thick diaphragm is curved to form a cystoidal diaphragm. 
In tangential view, zooecia range from integrate to narrowly amalgamate because of the narrowness of the zone of curved laminae. Mesopores are fairly common outside the monticules. Diaphragms in the mesopores are nearer the apertures than those of ordinary zooecia. Acanthopores are abundant; they inflect the zooecial walls and are not confined to the corners of the zooecia.

The following table is based on 27 fragments from 23 zoaria. Sections from 48 zoaria of $L$. mesostena mesostena were examined.

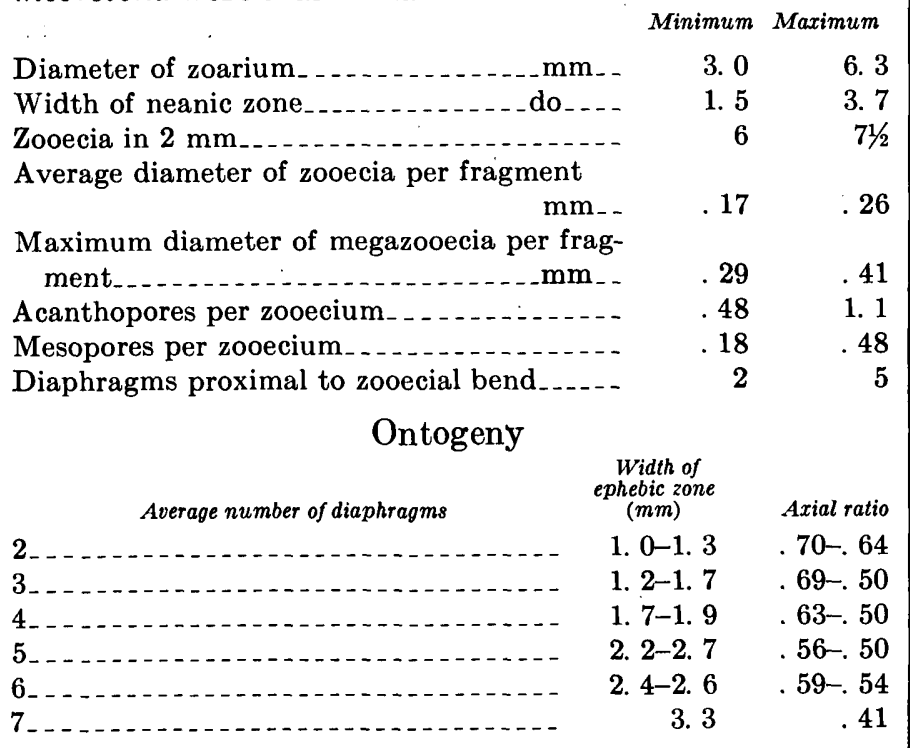

Types: Holotype USNM 133878 from USGS collection 3503-SD ; figured paratypes USNM 133876, 133877, 133879-133881.

Occurrence: Centerfield limestone member of the Ludlowville shale, USGS-SD 3503, 3571, 3593. Localities range from the Batavia quadrangle to Cayuga Lake.

Leptotrypella (Leptotrypella) mesostena provecta Boardman, n. subsp.

Plate 6, figures 7, 8

Diagnosis.-Ramose subspecies differentiated from the nominate subspecies by lack of fine crenulations in zooecial walls of neanic zones, slightly. wider zones of curved laminae, few thick and cystoidal diaphragms, and fewer integrate zooecia.

Description.-Zoaria are small and ramose. In the neanic region the zooecial walls are irregularly undulated and are not finely crenulated.

In the ephebic region the zones of curved laminae are generally intermediate in width between those of $L$. mesostena mesostena and L. multitecta. The zooecial linings are uniformly thick. Mural spines are common, and cysts were not observed. Diaphragms are simple, generally thin and planar. Thin cystoidal diaphragms and thick planar diaphragms are rare.
In tangential view, zooecia are generally amalgamate to narrowly amalgamate and are rarely integrate. Mural lacunae are present but probably are not common.

The following table is based on the 4 available fragments, presumably from 4 zoaria, of $L$. mesostena provecta.

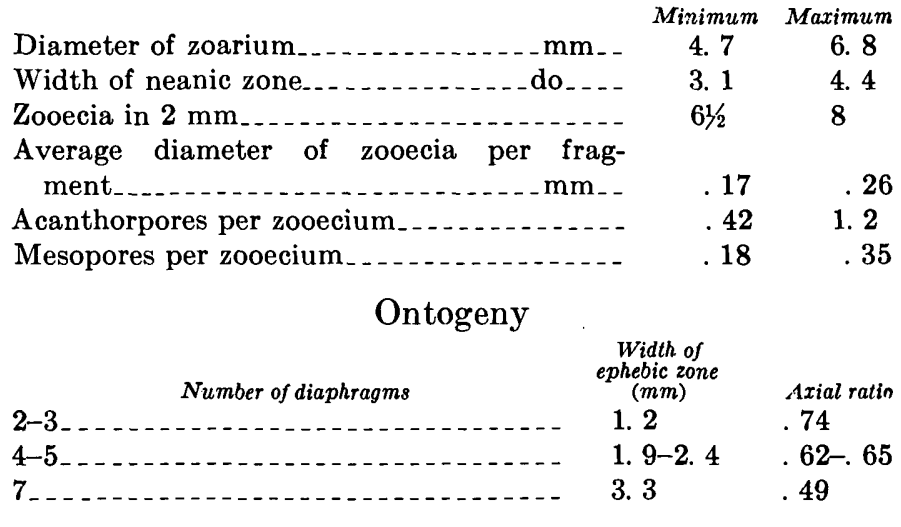

Remarks.-This subspecies occurs in the Ledyard member of the Ludlowville, stratigraphically between the occurrences of $L$. mesostena mesostena in the Centerfield limestone member and $L$. multitecta in the Wanakah shale and King Ferry members. The subspecies is also morphologically intermediate between the two forms but resembles $L$. mesostena mesostena more closely in qualitative characteristics.

Qualitative morphologic differences that separate the two subspecies of $L$. mesostena from $L$. multitecta occur in the early ephebic zones just proximal to the zooecial bends. The zooecia of the early ephebic zones of $L$. mesostena are constricted in diameter, generally contain three or four thin planar diaphragms and are nearly parallel to the length of the zoarial branch. The zooecia in the early ephebic zones of $L$. multitecta are not constricted, generally have 2 or 3 diaphragms, commonly display irregular wall fluctuations and are more nearly at right angles to the length of the zoarial branches. The zooecial bends in L. multitecta are also less abrupt and not as well defined as those of $L$. mesostena.

Qualitative characteristics that display a more gradual change in the $L$. mesostena-multitecta lineage and are about intermediate in L. mesostena provecta include the widening zones of curved laminae and the more amalgamate appearance of zooecial walls in tangential sections.

Quantitatively, the diameters of the neanic zones are generally smallest in the nominate subspecies of L. mesostena, intermediate in L. mesostena provecta and largest in L. multitecta (p. 53). Incorporating neanic zone measurements into axial ratios, the pro- 
gressive and overlapping change is shown in figure 24. Thus, for similar growth stages as determined by the number of diaphragms, corresponding values of axial ratios become generally higher upward in the proposed phylogenetic lineage.

Types: Holotype USNM 133883 from USGS collection 3541.SD; figured paratype USNM 133882.

Occurrence: Ledyard member (of Cooper, 1930) of the Ludlowville shale, USGS 3541-SD, from White Creek, Batavia quadrangle.

\section{Leptotrypella (Leptotrypella) multitecta Boardman, n. sp.}

Plate 7 , figs. $1-4$; plate 8 , figs. $3-8$

Diagnosis.-Zoaria ramose, incrusting, or both; overgrowth exceptionally well developed; in neanic region and ephebic region zooecial walls irregularly undulated; 2-3 diaphragms typical in early ephebic zone just proximal to the flattened and poorly defined zooecial bend; in ephebic region, zone of curved laminae characteristically wide; in tangential view, walls normally amalgamate, a few scattered zooecia integrate; mesopores unusually common for the genus.

Description.-Zoaria are ramose, incrusting, or a combination of the two habits. Overgrowth is characteristically well developed on ramose zoaria, 2 or 3 layers commonly occur on older branches., As a result, few zooids developed fully because their. growth was halted by the encroaching overgrowth. The ramose colonies were extended distally by these overgrowths building one upon the other. An overgrowth apparently grew from its point of origin in both a proximal and distal direction relative to the supporting colony. Proximally, the overgrowth incrusted the supporting colony. Distally beyond the tips of the supporting colony, the overgrowth assumed a ramose habit, thereby adding length to the complex structure (pl. 7, fig. $4 a)$. These overgrowths commonly result in irregularities such as knobby growths, right-angle bends in branches, or bifurcation of branches at unusual angles. Another growth habit within the species is demonstrated by zoaria that form incrustations that can give rise to branches (pl. 7, fig. 3). Incrusting zoaria are fairly common and display extremely variable zooecial characteristics (pl. 8, figs. 3, 7, 8).

Monticules are variable in height. They are composed of several megazooecia that may have thickened walls, a few mesopores in varying abundance, and enlarged acanthopores.

In the neanic region, zooecial walls display irregular undulations, but no consistent development of finer crenulations. The neanic regions are commonly interrupted by partial destruction of abandoned growing tips by either resorption or erosion. These older surfaces are covered by an overgrowth.

In the ephebic zone, irregular undulations are common in the walls of the zooecia so that parts of many zooecia are thrown slightly out of the plane of the longitudinal sections. Proximal to the zooecial bend are 2 or 3, very rarely four diaphragms. The zooecial bend is typically flattened and poorly defined. Zooecial linings are of variable thickness and some are not easily discernible from the generally wide zone of curved laminae. Diaphragms are simple, generally thin and planar. Thin cystoidal diaphragms and thick planar diaphragms are rare to fairly common. Few thick diaphragms are curved enough to become cystoidal. Mural spines are typically abundant but are rare in a few zoaria. If abundant, they commonly are concentrated near the zooecial bend. Incrusting zoaria generally display concentrations of mural spines near the proximal ends of the zooecia.

In tangential view, the walls generally appear amalgamate. An integrate appearance occurs in a few scattered zooecia throughout a zoarium and is more common in the thickened walls of monticular zooecia. A few zoaria display mural lacunae irregularly distributed in the zooecial walls. Mesopores outside the monticules are unusually abundant for the genus and are evenly distributed throughout a zoarium. Diaphragms of the mesopores are closer to the apertures than those of normal zooecia. Acanthopores are normally abundant, inflect the zooecial walls, and are not concentrated at the corners of the zooecia.

The following table is based on 92 fragments from 48 zoaria. Sections from over 100 zoaria of $L$. multitecta were examined.

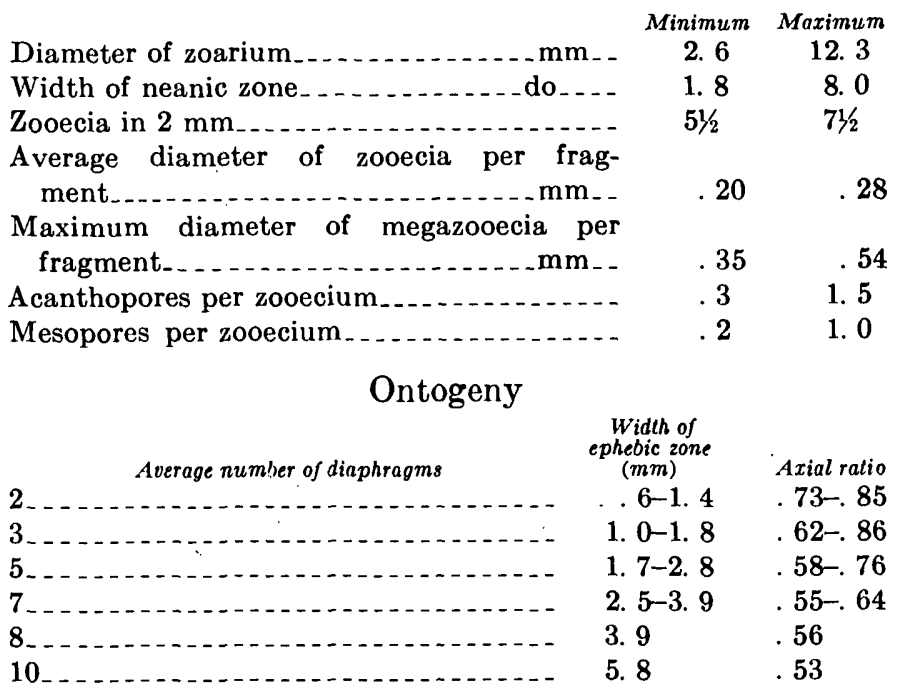

Remarks.-L. multitecta differs from $L$. devonica (Duncan) $(1939$, p. 259, pl. 14 , figs. 9,10$)$ in having 
monticules, more mesopores, and a larger axial ratio for corresponding growth stages. The holotype slide of $L$. devonica has 6-7 diaphragms in the zooecia and an axial ratio of $0.43: 1$. L. multitecta differs from $L$. magninodosa Duncan $(1939$, p. 226 , pl. 9, figs. 8-9) in having larger zooecia, smaller acanthopores, and larger axial ratios for corresponding growth stages. The holotype slide of $L$. magninodosa contains 6-8 diaphragms and has an axial ratio of $0.39: 1$.

$L$. multitecta differs from the holotype slide of $L$. aequabilis Duncan $(1939$, p. 224, pl. 9, figs. 6,7) mainly in a larger axial ratio for a similar number of diaphragms. The holotype section of $L$. aequabilis displays 8-9 diaphragms, neanic diameter of $2.3 \mathrm{~mm}$, ephebic width of $4.1 \mathrm{~mm}$, and an axial ratio of $0.36: 1$. Qualitatively, the two species are comparable. (For further discussion see p. 53).

T'ypes: Holotype USNM 133887 from USGS collection 3524-SD; figured paratypes USNM 133884-133886, 133889-133892.

Occurrence: Ludlowville shale: Wanakah shale member as used by Buehler and Tesmer (in press), USGS-SD 3502 (USNM collection 1017), 3505, 3511, 3512, 3514, 3515, 3516, 3519 , 3524, 3526, 3532, 3565; King Ferry shale member of Cooper (1930) USGS-SD 3564,3572 . Localities range from Lake Erie to Cayuga Lake.

Lep totrypella (Leptotrypella) asterica Boardman, n. sp.

Plate 9, figure 1 ; plate 10 , figures $1-6$

1877. Chaetetes fruticosus Hall (Part) New York State Geol. Survey, Paleontology, pl, 38, flgs. 1, 5.

Diagnosis.-Species extremely variable; zoaria large and ramose (maximum branch diameter $25 \mathrm{~mm}$ ); in addition to normal monticules, prominences formed by distally extended zooecial walls common, appear star-shaped in tangential sections. In ephebic zone: zooecial walls variable in thickness; thin-walled zooecia show irregular thickening and undulations, thin to discontinuous zooecial linings, rare mural spines, and thin irregularly spaced diaphragms; thick-walled zooecia less irregular, with fewer undulations in the walls, thicker more continuous zooecial linings, more abundant mural spines, and more regularly spaced diaphragms.

Description.-Zoaria are large and ramose, the most complete zoarium of the collection is $45 \mathrm{~cm}$ in height. Overgrowth is common and gives rise to secondary branches as well as the usual incrustations. Abundant overgrowth on a zoarium produces irregular to anastomosing branching, although the species basically has a simple, dichotomously branching habit. Bulbous to elongate swellings on older, proximal parts of zoaria appear to be stunted branches (pl. 10, fig. 2). Mon- ticules are abundant and generally low; they contain megazooecia with slightly thickened walls, few irregularly clustered mesopores, and enlarged acanthopores. In addition to these normal monticules there are prominences of comparable size composed of the distal ends of zooecia that are elongated toward the centers of the prominences in a radial pattern. In tangential view, the internal structure of the prominences resembles many-pointed stars. The voids in the prominences are partly filled with dark granular material.

In the neanic region, the zooecial walls are generally undeviating without crenulations or undulations. In the ephebic zone, the zooecial walls vary in thickness among zoaria or among zooecia in a single zoarium. The walls of individual zooecia display irregular thickening and undulations, both more pronounced where the walls are relatively thin. Also, in the thinwalled zooecia the lining is wanting or is thin and discontinuous, and mural spines are very rare. In the thick-walled zooecia, the lining is relatively thick and mural spines are more common. Where common, spines are generally concentrated just distal to the zooecial bend. All degrees of transition between extremes of wall thickness, undulations and abundance of mural spines can be seen within any one of a very few zoaria. Most zoaria are more regular but a number of zoaria together display the full range of morphologic variation. In longitudinal sections, the boundaries of many zooecia range from well-defined lines to serrated zones. In other zooecia the boundaries are poorly defined, the-laminae from adjacent zooecia merging with little apparent break. The zone of curved laminae is generally wide. All diaphragms are thin and planar to slightly curved. In zooecia with thin walls the diaphragms s.re widely and irregularly spaced. In zooecia with thicker walls, the diaphragms are more regularly and closely spaced. Cystlike bodies occur in the ephebic zones in varying numbers, singly or in clusters. If abundant in a zoarium, they occur either throughout the ephebic zone at all levels in the zoarium or unevenly concentrated in parts of the zoarium. The cysts have laminated walls continuous with laminae of the diaphragms or zooecial walls, and commonly inclose dark granular deposits.

In tangential view, apertures are subpolygonal to subcircular. The zooecial walls are amalgamate, less commonly integrate. Acanthopores are common, inflect the walls to some extent, and ordinarily occur at the corners of the zooecia. Mesopores are rare except in the monticules.

The following table is based on 65 fragments from 15 zoaria. Sections from 46 zoaria of $L$. asterica were examined. 


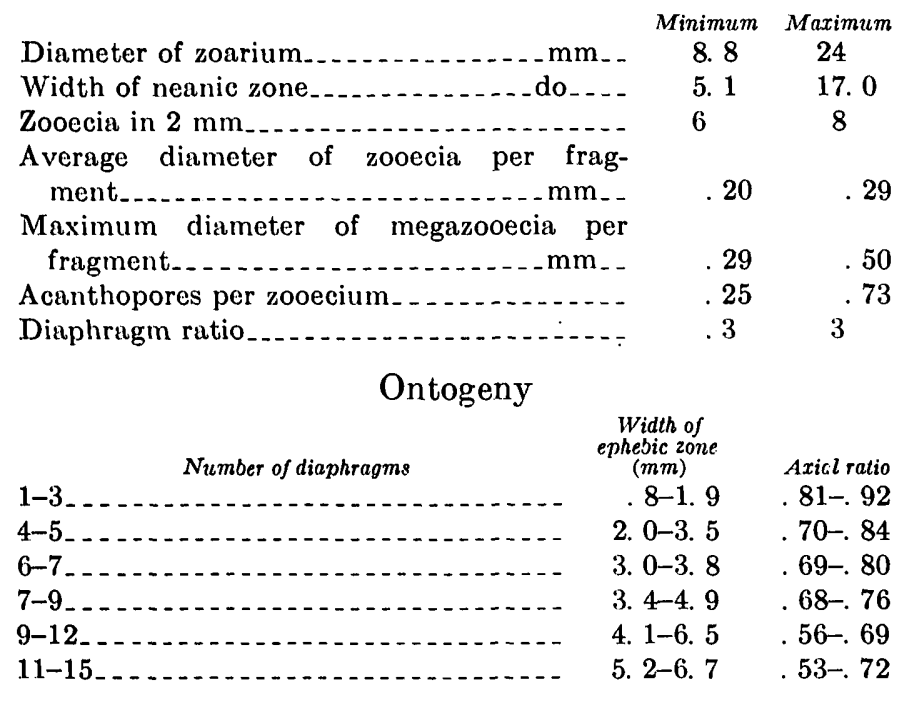

Remarks.-Hall (1877, pl. 38, figs. 1-5) erected Chaetetes fruticosus, figuring three unsectioned syntypes and giving no written description. Thin sections show that one of the syntypes (Hall, 1877, pl. 38, fig. 2) belongs to the genus Atactotoechus and this specimen is designated as the lectotype of Atactotoechus fruticosus (Hall) (p. 76). The remaining two syntypes (NYSM 6181, Hall, 1877, pl. 38, fig. 1 from Canandaigua Lake; NYSM 6183, Hall, 1877 pl. 38, fig. 5, from Western New York) belong to L. (Leptotrypella) asterica and are considered only as identified specimens of that species. (For further discussion see p. 60).

L. asterica is readily differentiated from the species of Leptotrypella from the Traverse group of Michigan and from $L$. mesostena and $L$. multitecta by its large zoaria and the presence of the star-shaped prominences.

Types: Holotype USNM 133893 from USGS collection 3543-SD; figured paratypes USNM 133894-133898.

Occurrence: Ludlowville shale: Wanakah shale member as used by Buehler and Tesmer (in press), USNM collection 1017; King Ferry shale member of Cooper (1930), USGS 3572-SD. Moscow shale: Portland Point member of Cooper (1930). USGS 3551-SD; Kashong member of Cooper (1930), USGS-SD $3500^{\circ}$ (USNM collection (39)) 3501, 3528a (USNM collection 277A) 3542, 3543, 3552, 3558 .

Although L. asterica first appears in the Ludlowville shale, it is very rare there. The species is extremely abundant in the Kashong member from the Attical quadrangle to Seneca Lake and is not known in the Windom member above.

Leptotrypella (Leptotrypella) furcata (Hall)

Plate 11, figures 1-6

1877. Chactetes furcatus Hall (part), New York State Geol. Survey, Paleontology, pl. 37, figs. 1-4, pl. 38, fig. 7 .
1939. Atactotoechus furcatus (Hall) Duncan, Univ. Michigan, Mus. Paleontology, Contr., vol. 5, p. 190.

Diagnosis.-Zoaria large, ramose (branch diameters 6.5 to $16.5 \mathrm{~mm}$ ) incrusting, or a combination of the two habits; monticular mesopores few and irregularly distributed, to abundant and clustered at center of monticule, surrounded by a ring of megazooecia; in neanic zone, zooecial walls irregularly undulating to crenulate; in ephebic zone, zooecial walls thick (maximum $0.18 \mathrm{~mm}$ ), consisting almost entirely of a zone of curved laminae with no distinct zooecial lining; zooecial walls broadly amalgamate.

Description.-Zoaria are both ramose and incrusting; and a combination of the two habits occurs in individual zoaria. Overgrowths are common and many are thick, contributing appreciably to the total diameter of the branches. Within the ephebic region, zones in which the tubes are thin walled commonly alternate with normal zones of thick-walled growth. In these alternations the zooecia are continuous, not interrupted by basal laminae at sharp breaks in wall thickness. Monticules are either not elevated or only slightly raised above the surrounding zooecia. The monticular megazooecia and mesopores have thickened walls. Some monticules have few mesopores irregularly scattered among the megazooecia, others display a central cluster of mesopores surrounded by megazooecia ( $\mathrm{pl}$. 11 , fig. $3 b$ ).

In the neanic region, zooecial walls are irregularly undulating to crenulate. In the early ephebic zone, the walls increase rapidly in thickness. In the ephebic zone, zooecial wall thickness is uniform except in a very few zoaria in which the walls are relatively thin and tend to be irregularly thickened and undulatory. Distinct zooecial linings are not observed, but the wall structure is leptotrypellid, with straight laminae paralleling the zooecia for some distance before curving broadly into the zooecial boundaries to form the unusually wide zone of curved laminae. Zooecial boundaries are commonly not defined; the laminae from adjoining zooecia merge without apparent break. Mural spines are never abundant, but a few generally occur in a zoarium. Small subspherical cysts attached to diaphragms or zooecial walls of the ephebic zones occur in most zoaria. Diaphragms are thin, planar, and widely and irregularly spaced. In a few zoaria, diaphragms are as much as 3 or 4 tube diameters apart.

In tangential view, the thicier walled zooecia have subcircular apertures. Thinner-walled zooecia have subcircular to subpolygonal apertures. Zooecial walls are broadly amalgamate, and mural lacunae occur in some zoaria. Mesopores are generally rare outside 
monticules. Acanthopores range from small to medium and are not confined to zooecial corners.

The following table is based on 27 fragments from 21 zoaria. Sections from 47 zoaria of $L$. furcata were examined.

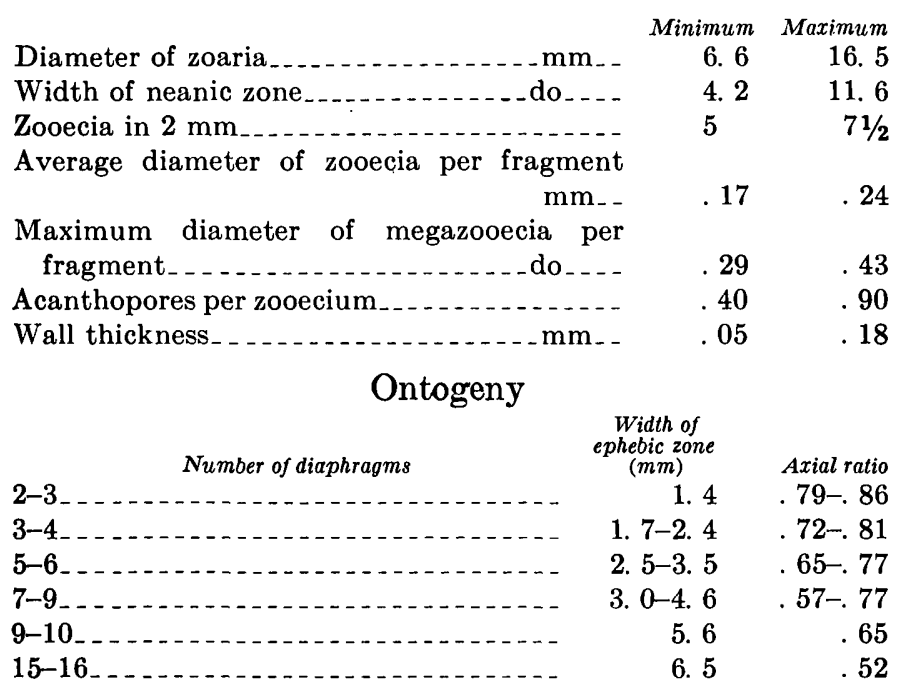

Remarks.-Hall (1877) published illustrations of syntypes of Chaetetes furcatus and $C$. fruticosus with no descriptions or designations of holotypes. Apparently, $C$. fruticosus was differentiated from $C$. furcatus by the presence of high monticules.

Grabau figured specimens that he identified as $C$. fruticosus (1899, p. 136, fig. 20) and $C$. furcatus (1899, p. 137 , fig. 21$)$ reassigning them to the genus Monotrypa. His specimens apparently were not sectioned so their identity is uncertain. Grabau's material was probably not identified correctly, as most of his specimens came from the Ludlowville shale. Only 1 of the 3 species Hall included in syntypes of $C$. fruticosus and $C$. furcatus have been found below the Moscow shale, and that one, L. asterica, is very rare in the Ludlowville shale.

Duncan (1939, p. 190) reassigned both $C$. fruticosus and $C$. furcatus to Atactotoechus without comment.

Sectioning of Hall's syntypes of $C$. furcatus revealed that 2 species were fortuitously included under the one name, largely because of the misleading external homeomorphy common in trepostomes. The syntype illustrated in pl. 37, fig. 5 (Hall, 1877) under the name $C$. furcatus does belong to the genus Atactotoechus and is now included in $A$. fruticosus (p. 76) as a homeotype. The remainder of the specimens designated by Hall as $C$. furcatus (NYSM 6184, pl. 37, fig. 1 ; NYSM 6185, pl. 37, fig. 2; NYSM 6187, pl. 38, fig. 7 ; the specimen in pl. 38 , fig. 6 was not available) are all the same species of the subgenus $L$. (Leptotrypella) and the name furcata is here retained for that species.
L. (Leptotrypella) furcata is considered to have evolved directly from L. (Leptotrypella) asterica (p. 58). Both species display thin, simple, widely spaced diaphragms, cysts, and mural spines. $L$. furcata differs from $L$. asterica in developing some crenulations in the zooecial walls of the neanic zones, and thicker ephebic walls showing wide zones of curved laminae and no distinct zooecial linings. Also, $L$. furcata has no star-shaped prominences and generally has more mesopores in the monticules.

Types: Lectotype NYSM no. 6187 (Hall, 1877, pl, 38, fig. 7) Bellona, Yates County, New York; paratypes NYSM no. 6185 (Hall, 1877, pl. 37, figs. 2, 4) Norton's landing, Cayuga Lake, New York and NYSM no. 6184 (Hall, 1877, pl. 37, figs. 1, 3) Norton's Landing, Cayuga Lake, New York; flgured specimens USNM 133899-133903.

Occurrence: Windom member of the Moscow shale, collection (52) and USGS-SD 3548, 3553, 3559, 3562, 3567, 3569, $3570,3575,3579$. Localities range from the Attica quadrangle to Owasco Lake. USGS 3559-SD constitutes topotype material from the Windom member in the Kashong Creek section at Bellona, N.Y.

\section{Leptotrypella (Leptotrypella) amplectens (Grabau) Plate 12, figures 1-5}

1899. Monotrypa amplectens Grabau, Buffalo Soc. Nat. Sci Bull., v. 6, p. 137, fig. 22.

1913. Monticulipora? marylandensis Ulrich and Bassler, Maryland Geol. Survey, p. 123, pl. 7, figs. 10-12.

Diagnosis.-Zoaria incrusting or incrusting and subramose, each zoarium intergrown with an auloporoid coral and incrusting a spiriferoid brachiopod; in monticules, megazooecial walls strongly thickened, acanthopores enlarged; alternating zones of thin and thick-walled growth in region generally only ephebic; mural spines few to common.

Description.-Grabau's description of the external appearance and the constant incrusting relationship of the species is excellent. All 38 specimens of $L$. amplectens identified by means of sections are intergrown with an auloporoid coral, and the bryozoan and the coral together incrust a spiriferoid brachiopod. Calices of the coral are generally concordant with the zoarial surface indicating equal growth rates of the two organisms. The coral is a species of Aulocystis Schluter [=Ceratopora $]$ originally identified by Grabau as Aulopora tubaeformis Goldfuss, and the brachiopod is Spinocyrtia granulosa (Conrad). The incrusting growth always occurs on the brachial valve of the brachiopod and is concentrated on the anterior half or two-thirds of that valve (pl. 12, fig. 4). In welldeveloped incrusting complexes the bryozoan and coral display the maximum thickness and short branches (maximum observed length of $11 / 2$ inches) at the extreme anterior end of the brachiopod (pl. 12, fig. 2). 
Each branch consists of a central growth of Aulocystis completely covered by the bryozoan except for exposed calices.

Monticules are variable in height, probably due in part to the irregular surface of attachment of the bryozoan. The monticules consist of zooecia and megazooecia with strongly thickened walls and much enlarged acanthopores that display unusually large lumina. Included mesopores are variable in number but show little increase in concentration over surrounding intermonticular areas.

Zoaria of $L$. amplectens are attached to the corallites of Aulocystis by a thin basal lamina produced by the bryozoan. The boundary between the neanic and ephebic zones is poorly defined because of the generally thin zooecial walls of the ephebic zones. In most incrusting trepostomatous Bryozoa, the distal part of the zooecium that is normal to the surface of the zoarium displays ephebic growth characteristics, even though constituting the greater part of the zooecial length. In $L$. amplectens, distal parts of continuous zooecial tubes oriented normal to the surface show an alternation of apparent neanic and ephebic growth. The intermittent ephebic zones are marked by a slight thickening of the zooecial walls and closer spacing of diaphragms. The possible neanic growth is marked by very thin walls and more widely spaced diaphragms. Zooecial walls range from undeviating to irregularly undulating to tightly crenulated. Zooecial linings are scarcely noticeable owing in part to their thinness. Mural spines are few to common and cysts are rare. Diaphragms are planar to irregularly curved and uniformly thin. Cystoidal diaphragms are rare.

In the tangential view, apertures are polygonal, and one or more sides of the apertures may be slightly curved. Zooecial walls are narrowly amalgamate to integrate, primarily because of their thinness. A few zoaria display mural lacunae, especially around the calices of the coral where the zooecial walls are generally slightly thicker. Acanthopores are large relative to the zooecial wall thickness and they inflect the walls. Mesopores vary in concentration from one zoarium to the next but are generally few and evenly distributed throughout a zoarium.

The following table is based on 12 fragments from 12 zoaria. Sections from 38 zoaria of $L$. amplectens were examined.

Zooecia in $2 \mathrm{~mm}$

Average diameter of zooecia per fragment mm. -

Maximum diameter of megazooecia per fragment......................

Acanthopores per zooecium

Mesopores per zooecium
Minimum Maximum $51 / 2 \quad 71 / 2$

.26 .32

Rare
Remarks.-Grabau suggested $(1899$, p. 139$)$ that the coral and bryozoan lived together as commensals and that the commensals began growth on the Spinocyrtia after the brachiopod shells were full grown and had rolled over to lie on their pedicle valves.

The constant relationship of the incrusting commensals to the brachial valves of the brachiopod does strongly suggest that all three forms lived simultaneously. Further, the concentration of incrusting growth on the anterior ends of the brachial valves plus the anterior extension of short branches generally parallel to the length of the shells suggest that the anterior margins of the shells were oriented upward toward the surface of the water with the posterior beaks down on or in the subtratum. There is no evidence favoring the upward orientation of either the pedicle or the dorsal valves, assuming that the living position of the brachiopod was not exactly vertical.

Monticulipora? marylandensis Ulrich and Bassler 1913, tentatively referred to Anomalotoechus by Duncan $(1939$, p. 188), is considered a junior synonym of L. amplectens both on identical morphologic appearances and the presence in the type sections of parts of a corallite and brachiopod similar in appearance in thin section to those associated with $L$. amplectens. Unfortunately, the remainder of the type specimen is too fragmentary to identify the brachiopod.

Types: Figured specimens USNM 72856, 133904-133907.

Occurrence: Grabau reported the species from the Pleurodictyum zone at Avery's Creek and the Wanakah Cliff, both along the shore of Lake Erie, Buffalo, New York; also in the calcareous bed, above the Pleurodictyum bed, at Avery's Creek. Ulrich and Bassler (1913b, p. 124) reported M.? marylandensis from the Romney shale, East bank of Evitt's Creek below Wolfe Mill in Maryland. In addition, the species occurs in the Wanakah shale member of the Ludlowville shale in USNM collection 280 and USGS-SD 3502 (USNM collection 1017) 3505, 3519, 3565, all from the Buffalo and Depew quadrangles.

Leptotrypella (Leptotrypella) magniporta Boardman, n. sp.

Plate 12, figures 6,7

Diagnosis.-Zoaria incrusting; megazooecia unusually large (maximum diameter $0.6 \mathrm{~mm}$ ), megazooecial walls not thickened; ephebic zooecial walls thin; diaphragms thin, closely spaced, few nonparallel forming cystoidal diaphragms.

Description.-Zoaria are incrusting and overgrowth is common. The species generally incrusts both valves of Athyris spiriferoides (Eaton) but also occurs on other brachiopods and less commonly on small horn corals. Monticules are moderately high and are composed of unusually large megazooecia (maximum 
diameter $0.6 \mathrm{~mm}$ ). Intermonticular acanthopores may be slightly enlarged but wall thicknesses are not increased and mesopores are extremely rare.

The neanic region is short and nearly vertical to the incrusting surface. Zooecial walls of the ephebic region are only slightly thicker than the walls of the neanic region and show little variation in thickness. Zooecial walls are commonly undeviating in longitudinal section but develop irregular undulations above uneven surfaces of attachment. Because of the thinness of the zooecial walls, zooecial linings are rarely seen, nearly the complete thickness of the wall being formed by the zone of curved laminae. Zooecial boundaries are generally not visible. Diaphragms are thin, closely spaced (diaphragm ratio normally less than 1) and a few are nonparallel and slightly curved, forming cystoidal diaphragms.

In tangential view, the zooecia are unusually large and sharply polygonal in cross section. The wall structure appears integrate to narrowly amalgamate because of the thin walls. Mesopores are very rare throughout the zoaria. Acanthopores are extremely variable in size and number and occur either between or at the zooecial corners.

The following table is based on 8 fragments from 7 zoaria. Sections from 10 zoaria of L. magniporta were examined.

\begin{tabular}{|c|c|c|}
\hline \multirow{4}{*}{$\begin{array}{l}\text { Diaphragms per mm. ephebic zone } \\
\text { Zooecia in } 2 \mathrm{~mm} \\
\text { Average diameter of zooecia per fragment }\end{array}$} & Mіпітит & Maximum \\
\hline & 3. 4 & 5. 4 \\
\hline & 5 & $61 / 2$ \\
\hline & 29 & 38 \\
\hline $\begin{array}{l}\text { Maximum diameter of megazooecia per } \\
\text { fragment }\end{array}$ & $\begin{array}{r}.44 \\
\text { Rare }\end{array}$ & $\begin{array}{r}61 \\
74\end{array}$ \\
\hline Ontogeny & & \\
\hline $\begin{array}{cc}\begin{array}{c}\text { Number of } \\
\text { diaphragms }\end{array} & \begin{array}{c}\text { Width of } \\
\text { ephebic zone } \\
\text { (mm })\end{array} \\
3-4 & .9 \\
7-9 & 1.3-2.0 \\
17 & 3.3\end{array}$ & & \\
\hline
\end{tabular}

Remarks.-A single specimen was collected at the Windom locality and differs from the Wanakah specimens only in having thicker zooecial walls. L. magniporta can be differentiated from $L$. amplectens by the large megazooecia of normal wall thickness, close spacing of diaphragms, and the lack of commensal relationships characteristic of $L$. amplectens.

Types: Holotype, USNM 133909 from USGS collection 3565 ; figured paratype, 133908.

Occurrence: Ludlowville shale: Wanakah shale member as used by Buehler and Tesmer (in press), USGS-SD 3515, 3516, 3565; Tichenor limestone member, USNM collection 250B. Moscow shale: Windom member, USGS 3585-SD. Localities range from Lake Erie to Canandaigua Lake.
Subgenus PYCNOBASIS Boardman, n. subgen.

Type species.-Leptotrypella (Pycnobasis) amphelicta Boardman, n.sp.

Definition.-The subgenus includes those species of Leptotrypella Vinassa de Regny 1920, that contain compound as well as simple diaphragms. Characteristically, the diaphragms are variable in thickness and in different combinations can be closely and irregularly spaced, strongly curved, and non-parallel. Cystoidal diaphragms are common and are formed by thick as well as thin curved diaphragms. Also, the zooecial linings of the subgenus are thick and most species have a narrow zone of curved laminae resulting in a narrowly amalgamate to integrate appearance in tangential sections.

Remarks.-The diaphragms of $L$. (Pycnobasis) approach, in configuration and arrangement, diaphragms typical of the atactotoechids (p. 69). The taxonomic importance of the nature and arrangement of diaphragms is well demonstrated by their constancy when correlated with wall structures in several suprageneric groups, such as the stereotoechids and atactotoechids. It is, therefore, of interest and importance to find forms with a distinctly leptotrypellid wall developing diaphragms of atactotoechid aspect.

Wall structure is presently considered to be the most definitive of the family characters and the subgenus has strongly leptotrypellid walls, thus suggesting affinities with Leptotrypella. In addition to wall structure, the acanthopores of $L$. (Pycnobasis) are typical of Leptotrypella rather than the distinctly different acanthopores of the atactotoechids.

If the New York forms are adequate to demonstrate the origin of the subgenus, the development of diaphragms of atactotoechid appearance is gradual and a matter of degree, with the exception of the sudden appearance of compound diaphragms. Thus, an independent and parallel evolutionary development of atactotoechid-like diaphragms in Leptotrypella is indicated. No known phylogenetic connection is developed between the subgenus and the atactotoechids of the Hamilton group in New York.

Another character typical of L. (Pycnobasis) that would seem to indicate possible atactotoechid affinities is the integrate appearance of some of the forms in tangential sections. However, integrate appearance can be manifested in two fundamentally different types of wall structure (p. 30). In L. Pycnobasis), integrate appearance is the result of a narrow but distinct zone of curved laminae. In the atactotoechids it is the result of laminae that remain straight up to their ends at the zooecial boundaries. Thus, an integrate appear- 
ance by itself is not considered to be of family importance in determining the affinities of $L$. (Pycnobasis.)

Specimens belonging to the subgenus are geographically restricted in occurrence to the 40 mile long strike distance between Canandaigua and Cayuga Lakes (fig. 4). The field collecting was done in enough detail throughout the area between Buffalo and Cayuga Lake to suggest that this geographic distribution is not fortuitous. The relatively small geographic range may be the result of close environmental control, as the shale and mudstone farther west become more silty in the eastern area of occurrence (p. 15). In keeping with the inferred phylogenetic relationships, the Canandaigua-Cayuga Lake region is postulated to be at least part of the region in which the subspecies evolved from the more conservative lineages of $L$. (Leptotrypella).

Zoaria of $L$. (Pycnobasis) available for study are few; three of the four species named here are represented by one to three zoaria. Under most circumstances the naming of new species based on so few specimens is merely guesswork and considered poor practice. However, the genus Leptotrypella is the most abundantly represented trepostone genus in the Hamilton group of New York and most of the species are known from more than adequate numbers of zoaria. Study of these large numbers of zoaria indicate the approximate amount of variation that can be expected for the characters considered to be of specific value and also demonstrates morphologic gaps between the well known species and the poorly known species of $L$. (Pycnobasis). Because of this generally good understanding of the genus, and the phylogenetic importance that is indicated by the poorly known species of L. (Pyonobasis), L. pachyphragma, L. tuberata, and $L$. polita are described on material generally considered to be inadequate in numbers of specimens.

Inferred phylogeny of L. (Pycnobasis).-L. (Leptotrypella) mesostena mesostena ( $p .55$ ) is considered to be a subspecies close to the point of phylogenetic divergence of $L$. (Pycnobasis) from $L$. (Leptotrypella). The subspecies displays some characteristics of both subgenera of Leptotrypella and probably was ancestral to $L$. (Pycnobasis) amphelicta (fig. 23) as well as $L$. multitecta (p. 57). The diaphragms of $L$. mesostena mesotena are intermediate between those of the subgenera. The subspecies displays diaphragms that are thin, regularly spaced, and planar to slightly curved, typical of $L$. (Leptotrypella), and many diaphragms that are cystoidal or thick, more typical of $L$. (Pycnobasis). The cystoidal diaphragms of $L$. mesostena mesostena generally are thin and occur in several species of L. (Leptotrypella). A few thick cystoidal diaphragms occur in $L$. mesostena mesostena, however, and these are fairly common in L. (Pyonobasis) and are very rare in L. (Leptotrypella). No compound diaphragms were observed in $L$. mesostena mesostena, however, so the species is placed in $L$. (Leptotrypella). Other characters of the subspecies considered intermediate or more typical of L. (Pycnobasis) include thick zooecial linings, narrow zones of curved laminae, and a resulting integrate to narrowly amalgamate appearance in tangential sections.

A phylogenetic connection between the subgenera seems most likely between $L$ : mesostena mesostena and L. (Pycnobasis) amphelicta (fig. 23). Morphologic similarities between the two taxa include the nature of the diaphragms discussed in the preceding paragraph plus crenulated neanic zones that are found in both forms. Morphologic changes observed from the subspecies to $L$. amphelicta include the development of compound diaphragms, more common thick cystoidal diaphragms, slightly wider zones of curved laminae, higher monticules, larger neanic diameters, higher axial ratios for any one growth stage, less abrupt zooecial bends, and a generally more amalgamate appearance.

The remainder of the species of $L$. (Pycnobasis) are not well enough known to attempt to arrange them phylogenetically. The few zoaria available do show a progressive change from amalgamate to narrowly amalgamate to integrate appearances in tangential sections if arranged stratigraphically. Also, the diaphragms become strongly atactotoechid in appearance; L. tuberata displays monticular diaphragms similar to the diaphragms of the genus Loxophragma (p. 78) and L. polita contains diaphragms characteristic of Atactotoechus (p. 69).

Leptotrypella (Pycnobasis) amphelicta Boardman, n. sp.

Plate 13, figures 1-4

Diagnosis.-Medium-sized ramose species (maximum diameter of branches about $9 \mathrm{~mm}$ ) with high monticules displaying irregular zooecial growth, undulating to strongly crenulate zooecial walls in neanic zone, planar to strongly curved diaphragms varying in thickness and spacing and commonly cystoidal, and moderately wide zones of curved laminae resulting in amalgamate intermonticular zooecia.

Description.-Zoaria are ramose, and overgrowth is rare. Monticules are high and display irregular to chaotic zooecial growth in longitudinal view. Megazooecia have strongly thickened walls, and acantho- 
pores may be enlarged. A few mesopores are irregularly clustered near the center of the monticule or scattered between the megazooecia.

In the neanic region, zooecial walls have fine, well developed crenulations or irregular, more widely spaced undulations that are especially strong near the ephebic zone. In the ephebic zone, the walls are generally straight. Undulations of the neanic walls extend into the thickened walls of a few zooecia, however, and these walls commonly have some irregularities in thickness. Zooecial linings are thick and continuous. The zones of curved laminae are wider than those of $L$. mesostena and nearly comparable with those of L. multitecta. The zooecial boundary is either undistinguishable or a narrow serrated zone of abutting laminae. Mural spines are rare to common and do not concentrate in the early ephebic zones of the zooecia as is common in several other species of the genus. Diaphragms are irregularly spaced, planar to strongly curved, and variable in thickness. Thick or thin cystoidal diaphragms are common. Thicker diaphragms commonly have compound structure.

In the tangential view, zooecial apertures are subpolygonal to subcircular. The walls are generally amalgamate, but a few zooecia appear integrate. Walls of megazooecia are integrate to narrowly amalgamate. Mural lacunae are common, especially in the monticules. Mesopores are scarce to fairly common. Acanthopores are common but rarely inflect the zooecial walls. Specimens sectioned in the original matrix show acanthopores extending as much as $1.5 \mathrm{~mm}$ beyond the zooecial apertures. The parts of the acanthopores that extend beyond the zoaria are slightly curved and taper gradually to a rounded point:

The following table is based on 11 fragments from 6 zoaria. Sections from 12 zoaria of L. amphelicta were examined.

\begin{tabular}{|c|c|c|}
\hline & & \\
\hline Diameter of zoarium & 4.9 & 8. 8 \\
\hline Width of neanic zone & 3. 3 & \\
\hline Zooecia in $2 \mathrm{~mm}$ & $51 / 2$ & \\
\hline \multicolumn{3}{|l|}{ Average diameter of zooecia per fragment } \\
\hline & 20 & 26 \\
\hline \multicolumn{2}{|l|}{ Maximum diameter of megazooecia per } & 38 \\
\hline Acanthopores per zooecium & .50 & 72 \\
\hline \multirow{2}{*}{\multicolumn{3}{|c|}{ Mesopores per zooecium }} \\
\hline & & \\
\hline \multicolumn{2}{|c|}{$\begin{array}{l}\text { Width of } \\
\text { ephebic zone } \\
(m m)\end{array}$} & \\
\hline \multirow{2}{*}{$3-3$} & & $.67-.71$ \\
\hline & $7-2.3$ & $68-.74$ \\
\hline 6 & 22 & \\
\hline
\end{tabular}

Remarks.-L. amphelicta differs from $L$. mesostena mesostena in developing more strongly curved and ir- regularly spaced diaphragms that are commonly compound. Cystoidal diaphragms are generally thicker and compound in $L$. amphelicta. In addition, in $L$. amphelicta the zones of curved laminae are wider, monticules are higher, neanic diameters are larger, axial ratios are higher for corresponding growth stages, and the zooecial bends are less abrupt and well defined than in L. mesostena mesostena.

L. amphelicta differs from L. (Leptotrypella) multitecta mainly in the crenulate zooecial walls of the neanic zones, thicker zooecial linings, high monticules, and the nature of the diaphragms.

The unusual distal extension of acanthopores beyond the zoarium may be more common within the genus than is apparent. In addition to those acanthopores protected by matrix in available specimens of $L$. amphelicta, a few acanthopores extend well into protecting overgrowths in free specimens of most species. Since most of the Hamilton material is free of surrounding matrix, those long acanthopores are normally broken, leaving no indication of their length beyond the surface of the zoarium.

Types: Holotype USNM 133910 from USGS collection 3558a-SD; figured paratypes USNM 133911, 133912, 133992.

Occurrence: Ludlowville shale: Wanakah shale member as used by Buehler and Tesmer (in press), USGS 3558a-SD; Tichenor limestone member, USGS 3586-SD. Moscow shale: Kashong member of Cooper (1930), USGS-SD 3552, 3558. Localities range from Canandaigua Lake to Seneca Lake.

Leptotrypella (Pycnobasis) pachyphragma Boardman, n. sp.

Plate 15, figures 3, 4

Diagnosis.-Ramose species distinguished by generally thick, planar to slightly curved, regularly spaced and parallel diaphragms; zooecial walls thick, linings thick, zone of curved laminae thin; resulting in narrowly amalgamate, less commonly integrate appearances in tangential view.

Description.-Zoaria are ramose and overgrowth is common. Monticules are variable in height from colony to colony. The diameters of the megazooecia are about twice the diameters of the intermonticular zooecia and are generally more integrate in tangential view. Mesopores are either irregularly scattered or centrally clustered in the monticules. The thickness of monticular zooecial walls is slightly to greatly increased over the walls of surrounding zooecia.

In the neanic region, the zooecial walls are undeviating to irregularly undulating. In the ephebic zone, the zooecial walls are thick, (average $0.1 \mathrm{~mm}$ ). The zone of curved laminae is relatively narrow and generally the zooecial boundary is visible as a serrated 
zone of overlapping and abutting laminae. The zooecial lining is thick, contributing more than half of the wall thickness. The diaphragms are characteristically thick, causing abrupt increases in wall thickness as the diaphragm laminae join the wall. The diaphragms are planar to slightly curved, generally parallel to each other, and regularly spaced. Compound diaphragms are fairly numerous and cystoidal diaphragms are rare to common. Mural spines are variable in concentration and if abundant are concentrated just distal to the zooecial bend. The spines are characteristically irregular in shape, many are strongly curved and bent, and a few are dichotomously branched. Cysts are variable in number, irregularly distributed in zoaria, and many are thick walled.

In tangential view, apertures are subpolygonal to circular. Zooecial walls are generally narrowly amalgamate, less conmmonly integrate. Mural lacunae are abundant in the narrowly amalgamate walls. Acanthopores are small to medium sized, not confined to zooecial corners and a few display central canals. Mespores are unequally distributed through a zoarium and are more closely tabulated than the zooecia.

Remarks.-Only two zoaria of this species are available for study. The holotype is from the Tichenor limestone member of the Ludlowville shale and seven large fragments of the zoarium were sectioned. The second zoarium is from the Wanakah shale member of the Ludlowville shale and three fragments were sectioned. Despite the inadequate number of zoaria, the species is thought to be distinct, based on the nature of the diaphragms, and is included because of its possible importance to the phylogeny of the genus.

\begin{tabular}{|c|c|c|}
\hline & Minimum & Maximum \\
\hline Diameter of zoarium & 7. 4 & 10. 6 \\
\hline Width of neanic zone & 4. 2 & 7. 0 \\
\hline Zooecia in $2 \mathrm{~mm}$ & 6 & $71 / 2$ \\
\hline Average diameter of zooecia per fragment & & \\
\hline mm_. & .18 & .27 \\
\hline $\begin{array}{l}\text { Maximum diameter of megazooecia per } \\
\text { fragment }\end{array}$ & 35 & 49 \\
\hline Acanthopores per zooecium & .38 & 68 \\
\hline Mesopores per zooecium & Rare & 33 \\
\hline Ontogeny of holotype & & \\
\hline Number of diaphragms & & Axial ratio \\
\hline-9 & $\begin{array}{l}3-3.7 \\
9-4.2\end{array}$ & $\begin{array}{l}.53-.69 \\
57-67\end{array}$ \\
\hline
\end{tabular}

Types: Holotýpe USNM 133918 from USGS collection 3586-SD; paratype USNM 133919.

Occurrence: Lidlowville shale: Wanakah shale member as used by Buehler and Tesmer (in press), USGS 3555-SD; Tichenor limestone member, USGS 3586-SD. Both localities are on Canandaigua Lake.
Leptotrypella (Pycnobasis) tuberata Boardman, n. sp.

Plate 14, figures 1,2

Diagnosis.-Species distinguished by subramose growth habit; extremely high monticules consisting of an irregular growth of centrally grouped mesopores surrounded by megazooecia with greatly thickened walls, and extremely enlarged acanthopores; many compound monticular diaphragms, nonparallel and unevenly and closely spaced; thin and planar intermonticular diaphragms; integrate zooecial walls.

Description.-Zoaria are subramose and branches are thick (maximum diameter $22 \mathrm{~mm}$ ) and relatively short (complete colony has height of $10.3 \mathrm{~cm}$ ). Some zoaria display overgrowth. Monticules are extremely high and are prominent in external views of the zoaria. The structures of the monticules commonly display irregular to chaotic growth. An irregular grouping of mesopores generally occurs near the center of a monticule. The mesopores are surrounded by, or distributed irregularly between, megazooecia of moderate diameters. The walls of the megazooecia and mesopores generally are greatly thickened and the monticular acanthopores are much enlarged.

In the neanic region the zooecial walls are straight to irregularly undulating. In the ephebic zones, the zooecial boundary is a well defined irregularly serrated zone of overlapping laminae that meanders back and forth within the zone of curved laminae. The abutting of the laminae at the zooecial boundaries is commonly imperfect, leaving voids that produce mural lacunae seen in the tangential sections. The zone of curved laminae is relatively narrow. The zooecial linings are generally continuous but vary greatly in thickness depending upon the thickness of the immediately proximal diaphragms that continue into the zooecial linings. The thicker diaphragms form thick zooecial linings just distal to the junctions of the diaphragms with the zooecial walls. The thicker diaphragms occur in similar positions in neighboring zooecia and are generally grouped into zones of several diaphragms that normally are also more closely spaced. The zooecial walls are therefore thicker within these zones of thicker diaphragms. The intervening thinner walled zones commonly become neanic in appearance and may continue for considerable distances along the lengths of the zooecia, resulting in a zone that appears alternately ephebic and neanic, in a generally ephebic region. Most diaphragms are simple, thin, planar and perpendicular to the zooecia in intermonticular regions. Compound diaphragms are rare in zooecia between monticules. In monticules, compound diaphragms are fairly common and are 
generally nonparallel, and unevenly and closely spaced, as in the genus Loxophragma in the atactotoechid group (p. 78). A few cystoidal diaphragms occur throughout a zoarium. Small thick-walled cysts are rare and generally are attached to the diaphragms. Mural spines are rare.

In the tangential view, zooecial apertures are subpolygonal to subcircular. The zooecial walls are generally integrate, but a few zooecia appear narrowly amalgamate. The holotype zoarium rarely has mural lacunae but the unfigured paratype displays them evenly distributed in monticular and intermonticular areas. Mesopores are rare outside the monticules. Acanthopores occur both at and between zooecial corners and many are on one side or the other of the zooecial boundary and strongly inflect the walls.

The following table is based on 8 fragments from the 3 available zoaria of $L$. tuberata.

\begin{tabular}{|c|c|c|}
\hline & Minimum & Maximum \\
\hline Diameter of zoarium & 10. 1 & 22. 0 \\
\hline Width of neanic zone & 7.5 & 16. 2 \\
\hline Zooecia in $2 \mathrm{~mm}$ & 7 & $71 / 2$ \\
\hline Acanthopores per zooecium & .50 & \\
\hline Mesopores per zooecium & Rare & \\
\hline Average diameter of zooecia per frag- & .23 & \\
\hline $\begin{array}{l}\text { Maximum diameter of megazooecia per } \\
\text { fragment_ }\end{array}$ & .32 & .44 \\
\hline \multicolumn{3}{|l|}{ Ontogeny } \\
\hline Number of diaphragms & $\begin{array}{l}\text { Width of } \\
\text { ephebic 2one } \\
(\mathrm{mm})\end{array}$ & Axial ratio \\
\hline 品 & 2. 3 & 0.77 \\
\hline 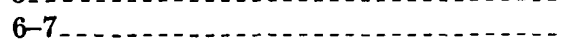 & 2. $9-3.9$ & $.72-.82$ \\
\hline $15-17$ & 6. 4 & \\
\hline
\end{tabular}

Types: Holotype USNM 133914 from USGS collection 3582-SD ; figured paratype USNM 133915.

Occurrence: Ludlowville shale: King Ferry shale member of Cooper (1930), USGS 3582-SD; Deep Run member of Cooper (1930), USGS 3555a-SD. Collections are from Cayuga Lake and Canandaigua Lake respectively.

Leptotrypella (Pycnobasis) polita Boardman, n. sp.

Plate 13, flgure 5 ; plate 14, figure 3

Diagnosis.-Large ramose species distinguished by low monticules containing few mesopores; parallel, closely spaced, planar to curved diaphragms, commonly cystoidal and compound; narrow zone of curved laminae resulting in generally integrate zooecial walls.

Description.-Zoaria are large and ramose. Overgrowth is common. Monticules are either low or not raised above the surrounding zooecia. Megazooecia have slightly thickened walls, acanthopores are unchanged to slightly enlarged, and mesopores are rare and irregularly distributed in the monticules.

In the neanic region, the zooecial walls typically are irregularly undulating to crenulated. In the ephebic zone, the zooecial boundary is either not visible or an irregularly serrated zone of overlapping laminae that meanders back and forth within the narrow zone of curved laminae. The zooecial linings are generally thick and continuous. Diaphragms are typically parallel, closely spaced, and planar to slightly curved. Thicker diaphragms may be compound and cystoidal diaphragms are common. The diaphragms approach those of the genus Atactotoechus (p. 69) in their general appearance. Mural spines are abundant and are generally concentrated just distal to the poorly defined zooecial bends or in the proximal regions of overgrowth. Cysts are rare and are small and thick walled.

In the tangential view, zooecial apertures are subpolygonal to subcircular. The zooecial walls are generally integrate, but a few zooecia appear narrowly amalgamate. Mural lacunae are rare and occur only in the narrowly amalgamate walls. Acanthopores are abundant, are not restricted to the corners of the zooecia and generally inflect the zooecial walls. Mesopores are rare.

The following table is based on ten fragments from the one available zoarium of $L$. polita.

\begin{tabular}{|c|c|c|}
\hline & Mіпітит & Махітит \\
\hline 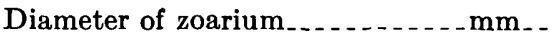 & 7. 6 & 14. 4 \\
\hline Width of neanic zone........... do.... & 5. 8 & 9. 6 \\
\hline Zooecia in $2 \mathrm{~mm}$ & $51 / 2$ & $61 / 2$ \\
\hline \multirow{2}{*}{\multicolumn{3}{|c|}{$\begin{array}{c}\text { Average diameter of zooecia per frag- } \\
\text { ment }\end{array}$}} \\
\hline & 26 & 29 \\
\hline \multirow{2}{*}{\multicolumn{3}{|c|}{$\begin{array}{l}\text { Maximum diameter of megazooecia per } \\
\text { fragment }\end{array}$}} \\
\hline & & 48 \\
\hline Acanthopores per zooecium $\ldots \ldots \ldots$ & 50 & 73 \\
\hline Mesopores per zooecium & Rare & 19 \\
\hline \multicolumn{3}{|l|}{ Ontogeny } \\
\hline Number of diaphragms & $\begin{array}{l}\text { Width of } \\
\text { ephehic zone } \\
(\mathrm{mm})\end{array}$ & Axial ratio \\
\hline $1-5$ & 1. 4-2. 1 & $.78-.82$ \\
\hline $6-8 \ldots \ldots$ & 2. 5-2. 6 & .70 \\
\hline 12 & 4. 6 & 61 \\
\hline $14-17$ & 5. 2-5. 6 & 61 \\
\hline 18 & 5. 5 & .55 \\
\hline
\end{tabular}

Remarks.-Only one zoarium of this description was available for study but it is notable for the remarkable similarity of its diaphragms with those of Atactotoechus, a genus with a quite different wall structure and at present thought to be in another family group. If present evaluations of the taxonomic importance of wall structure prove to be sound, the development of "atactotoechid" diaphragms in $L$. polita must have been independent and an example of parallel evolution (p. 62).

Type: Holotype USNM 133913 from USGS collection 3558-SD.

Occurrence: Kashong member of Cooper (1930) of the Moscow shale, USGS 3558-SD, Kashong Creek, Seneca Lake. 
Genus POIYCYLINDRICUS Boardman, n. gen.

Type species.-Polycylindricus asphinctus Boardman, n. sp.

Diagnosis.-Dichotomously branching zoaria with additional small perpendicular secondary branches; zooecia parallel to length of branches and extremely long in neanic zone, progressively compressed away from the center of the branch, in some species zooecia completely constricted and walls coalesce to form a thick-walled cylinder separating neanic and ephebic zones; zooecia in any one zoarium either long and continuous from neanic to ephebic zones or short and limited to ephebic zone; ephebic zones narrow with few diaphragms; zooecial walls leptotrypellid; acanthopores common, extremely large in diameter, project well beyond surfaces of zoaria; mesopores rare.

Description.-Zoaria are ramose; the branches are cylindrical. In addition to normal dichotomous branching, discordantly smaller secondary branches are common and make an angle of approximately $90^{\circ}$ with the supporting branches. Monticules do not occur in all species. Externally, the zoaria have a distinctive spiny appearance due to large, extended acanthopores.

In the neanic zone, the zooecia are polygonal in cross section, extremely long, and parallel to the length of the branches. The zooecia become propressively more flattened in cross section from the centers of the branches outward, also developing curved outer walls that parallel the curved outer extremities of the branches. If the compression of the zooecia is complete, the walls of the outer zooecia of the neanic zone coalesce to form a thickened cylinder separating the neanic from the ephebic zones. If the zooecia do not collapse completely, the walls remain distinct and it is possible to trace individual zooecia from the neanic to ephebic zones. A single zooecium, running longitudinally in the neanic zone, remains in the outer row of that zone for a considerable distance. Thus, there are not as many tubes passing from the neanic zone to the ephebic zone as there are zooecia opening at the surface in the ephebic zone. To make up for this deficiency, short secondary zooecia arise from the outer side of the long primary zooecia in the outer row of the neanic zone. No communication is visible between the void of the primary tube and that of the secondary zooecia. These secondary zooecia show almost no neanic growth and develop a normal ephebic zone that opens out to the surface of the zoarium at normal angles. Finally, the primary zooecium forms an ephebic zone and opens at the surface of the zoarium adjacent to the most distal of the secondary zooecia attached to the primary zooecium. In tangential sec- tions, primary and secondary zooecia are not distinguishable.

The ephebic zone is characteristically narrow, with few diaphragms. Further outward growth is accomplished by an irregular thin-walled or neanic development, attached directly to the initial ephebic zone generally without an intervening basal lamination. This second thin-walled region is adjoined by another ephebic zone with diaphragms, and a few zoaria develop a second thick-walled cylinder, concentric with the smaller initial cylinder (pl. 16, fig. 5). The second cycle of growth gives rise to the perpendicular, secondary branches of the zoaria by developing elongated neanic zones in restricted areas. The wall structure is leptotrypellid (p. 32), the laminae of the ephebic walls lie parallel to the lengths of the zooecia for a considerable distance to form a zooecial lining. The laminae then curve distally out to the zooecial boundary and intersect the boundary at $90^{\circ}$. The large acanthopores have their maximum diameters near their bases.

In tangential section, the walls are amalgamate. Acanthopores are common, extremely large, and project well beyond the surface of the zoarium. Mesopores are rare.

Remarks.-The short secondary zooecia limited to the ephebic zone would be considered mesopores except they are not consistently small in diameter and cannot be distinguished from primary zooecia in tangential sections.

The formation of the cylinder or tube by the union of zooecial walls is unique in the Trepostomata and the acanthopores of the genus are very unusual in longitudinal shape and size. The wall structure appears leptotrypellid, but subsequent work may very well place the genus in another suprageneric grouping.

Dekayia devonica Ulrich 1890 , is here assigned to Polycylindricus. Ulrich described the species based on cotypes from two widely separated localities, the Falls of the Ohio at Louisville, Kentucky, and Eighteen Mile Creek, Buffalo, New York.

The cotypes from the Jeffersonville limestone at the Falls of the Ohio consist of several ramose fragments plus the fragment that matches the only illustration of the Falls of the Ohio material (Ulrich, 1890, pl. 45, fig. 5). All the material is silicified and thus cannot be profitably sectioned. Fortunately, Polycylindricus has a distinctive exterior and the illustrated fragment belongs to this genus. Of the remaining specimens, only one belongs to Polycylindricus. The other fragments belong to another unidentified genus.

The New York material consists of a single thin section plus three ramose fragments labeled as cotypes. 
Ulrich's illustrations (1890, pl. 45, figs. 5a-5d), include both the thin section and external views of one of the cotypes. The thin section is not adequate to determine the characters of the species, however, it belongs to Polycylindricus. The three fragments also belong to Polycylindricus. The label accompanying the New York specimens cites the Hamilton group of Eighteen Mile Creek and the specimens may be from any of the members of formations in the Hamilton group of that area.

The specimens of Polycylindricus from the Falls of the Ohio have definite convex monticules while those from New York have none, so they are not considered conspecific. Ulrich (1890, description of pl. 45, fig. $5 a)$, indicates the possibility of two species in describing the New York specimens: "A branching hollow fragment, probably representing another species" (that is, other than the specimen shown in figure 5 from the Falls of the Ohio). The published description of Dekayia devonica therefore includes observations from 3 species belonging to 2 genera.

The Falls of the Ohio specimens are the only ones of Polycylindricus known to have convex monticules. The name Polycylindricus devonicus (Ulrich) is restricted to this monticulate species and Ulrich's illustrated specimen (1890, pl. 45, fig. 5 USNM 136827), is here designated the lectotype of that species.

Polished transverse sections of Ulrich's Eighteen Mile Creek cotypes show an inner thickened wall separating the neanic and ephebic regions and they are placed in Polycylindricus clausus Boardman, n. sp.

Polycylindricus asphinctus Boardman, n. sp.

Plate 15, figures 1, 2

Diagnosis.-Species distinguished by constriction of zooecia in outer part of neanic zone without formation of thickened cylinder; finely crenulate zooecial walls in neanic zone.

Description.-Zoaria are small and ramose. Secondary or rejuvenated growth is common and produces discordantly small branches projecting at right angles to the main branches. Monticules are not distinguishable.

In the neanic region, the parallel zooecial walls are finely and irregularly crenulate. Complete compression of zooecia is uncommon in the outer portions of the region and the zooecial walls remain discrete, so that a thickened cylinder is not formed. In the early part of the ephebic zone, the walls increase in thickness slowly and uniformly. Nearing the apertures, the walls thicken abruptly and end in bluntly rounded margins that are controlled by the curved laminae in the walls. The diaphragms are thin and are located in the proximal portion of the ephebic zone preceding the sharp zooecial bend. No more than two diaphragms were observed in a zooecium. The zooecia reach the surface at extremely variable angles. As many as six short secondary zooecia arise from a long primary zooecium.

In the tangential view, zooecial apertures range from subpolygonal, partly subpolygonal and partly circular, to subcircular. Tangential thin sections are broadly amalgamate if they pass through the distally thickened walls. Acanthopores are well laminated and usually large. The larger acanthopores are equal in diameter to the largest zooecia and project beyond the zooecia as much as $0.2 \mathrm{~mm}$. Maximum diameters are attained either at the bases of the acanthopores or between the bases and approximately one-fourth of their length above the bases. From that maximum point the acanthopores decrease slowly in size ending in broadly rounded tips. Elongated apertures of zooecia are arranged radially around single acanthopores giving the group a petaloid appearance.

The following table is based on 8 thin sections from 7 zoaria. Sections from 11 zoaria of $P$. asphinctus were examined.

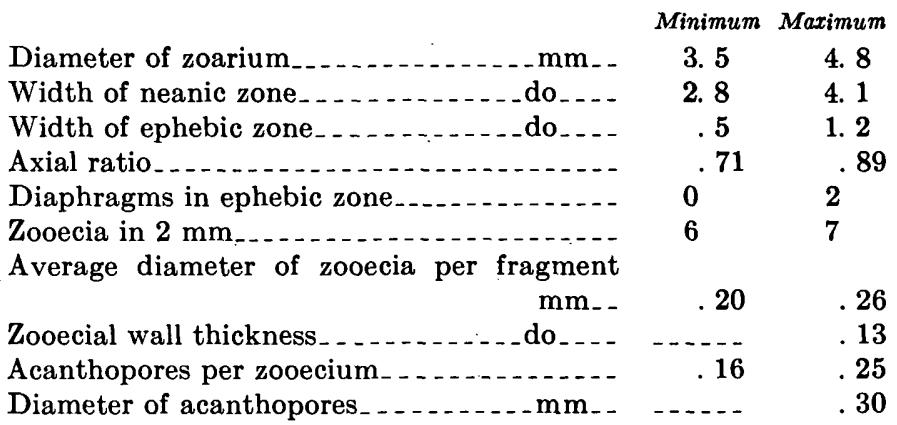

Types: Holotype USNM 133916 from USGS collection 3524-SD; figured paratype USNM 133917.

Occurrence: Wanakah shale member (as used by Buehler and Tesmer, in press) of the Ludlowville shale, USGS-SD $3515,3516,3524,3545,3565$. Localities range from Lake Erie to the Caledonia quadrangle.

Polycylindricus clausus Boardman, n. sp.

Plate 16, figures 1-6

1890. Dekayia devonica Ulrich (part), Illinois Geol. Survey, v. 8 , p. 416 , pl. 45 , figs. 5a-5d.

Diagnosis.-Species distinguished by thick-walled longitudinally plicated cylinder formed between neanic and ephebic zone by union of walls of compressed zooecia.

Description.-Zoaria are small and ramose. Discordantly small branches projecting at right angles to 
the main branches are common. Monticules are not distinguishable.

In the neanic region, the parallel zooecial walls are smooth or crenulated. The zooecia are completely constricted in the outer portions of the neanic regions, the individual zooecial walls uniting to form a thick longitudinally plicated cylinder. Although the cylinder makes it impossible to follow the individual zooecia from the neanic to the ephebic zones, the relationship between primary and secondary zooecia ( $p$. 67 ) is thought to be the same as that in $P$. asphinctus. The zooecia in the neanic zone so nearly parallel the cylinder that they join the cylinder at a much slower rate than the zooecia branch from the cylinder in the ephebic zone. Thus, many of the zooecia in the ephebic zone are not, continuous with the tubes in the neanic zone, so must have their origin in the ephebic zone as do the secondary zooecia of $P$. asphinctus. In the ephebic zone, the zooecial walls are usually thickened upon leaving the cylinders and increase gradually to a maximum near the aperture. The distal ends of the walls are broadly rounded. Normally, the zooecial walls are almost perpendicular to the cylinder throughout the ephebic zone. Rarely, zooecia separated from the cylinder wall proximal to the zooecial bend and developed 1 or 2 thin diaphragms.

In the tangential view, the zooecial boundaries and apertures are irregularly subpolygonal to subcircular, and vary from triangular to many sided and from elongated to equidimensional. The apertures also show an unusual range in size. Elongated zooecia are arranged radially around single acanthopores giving the grouping a petaloid appearance. The walls are amalgamate. Acanthopores are common and well laminated. From their broad bases, the acanthopores gradually decrease in diameter and end in broadly rounded tips. Mesopores are rare and difficult to distinguish in tangential sections due to the great variance in zooecial diameters.

The following table is based on 21 thin sections from 20 zoaria. Sections from more than 50 zoaria of $P$. clausus were examined.

Diameter of zoarium.............

Width of neanic zone.............. do ...

Minimum Maximum

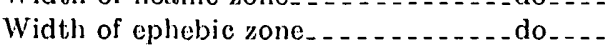

1. 9

1. 2

4. 8

Axial ratio . . . . . . .

Diuphrugms in ephebic zone

Cylinder thickness......................

Zooecia in $2 \mathrm{~mm}$

Zooecial wall thickness.............. mm .

Acanthopores per zooecium . . . . . . . . . . .

Dinmeter of acanthopores. . . . . . . . . mm .

.5

.59

.03

6

.03

.10

Types: Holotype USNM 133920 from USGS collection 3553-SD; figured paratypes USNM 133921-133925.
Occurrence: Ludlowville shale: Centerfield limestone member, USGS-SD 3503, 3571, 3593, USNM collection 1006; Ledyard member USGS 3541-SD. Moscow shale: Windom member, USGS-SD collections $3548,3553,3559$. Localities range from the Batavia quadrangle to Cayuga Lake.

The three syntypes of Dekayia devonica Ulrich 1890, here placed in the synonymy of $P$. clausus (see discussion p. 67) are from the Hamilton group, Eighteen Mile Creek. The geographic range therefore extends from Lake Erie to Cayuga Lake.

\section{ATACTOTOECHID GROUP}

Genera from the Hamilton group that display zooecial wall structure similar to that of the genus Atactotoechus Duncan, are placed together. As seen in longitudinal section, the zooecial wall laminae of the included genera are relatively straight as they extend distally to the zooecial boundaries and they intersect the boundaries at various angles of less than $90^{\circ}$. In tangential section the walls are generally integrate, but can appear amalgamate, depending on the angle that wall laminae make with the zooecial boundary (see p. 32 and fig. 13).

\section{Genus ATACtotoEchus Duncan}

1939. Atactotoechus Duncan, Univ. Michigan, Mus. Paleontology, Contr., v. 5, p. 190.

Type species.-Atactotoechus typicus Duncan 1939. Original definition.- "Zoarium ramose or massive. Walls intermittently thickened, thickened zones laminated, thin zones granular. Cystiphragms in mature and occasionally in immature zones, usually resemble slightly curved complete or incomplete diaphragms, but, occasionally, cysts are closed. Diaphragms and cystiphragms more numerous opposite thick-walled parts of zooecia. Intermittent thickening is a regular feature of zoarial growth, hence crowded bands of diaphragms and cystiphragms developed at intervals. Mesopores absent, but small zooecia occasionally present. Acanthopores laminated, few or absent, usually restricted to monticules or groups of larger zooecia." (Duncan 1939)

Remarks.-The definition of the genus is expanded to include incrusting zoaria and species containing mural spines. The granularity of the thin zones in the zooecial walls referred to in the generic definition above is due in part to poor preservation of the Traverse material. In well-preserved material the zooecial walls retain their laminated structure down to the point where the walls completely revert to neanic thicknesses. A complete reversion to neanic growth is not always attained but is common within the genus and is characterized by granular walls too thin to show laminae. 
Cystiphragms, as used in the original generic definition, include transverse elements distinguished here as curved diaphragms, cystoidal diaphragms, and cystiphragms, all defined in the glossary on page 21 . Also, the term mesopore as used in the present paper includes the small zooecia of the original definition.

In at least two species of Atactotoechus, $A$. cartus cartus (p. 73) and $A$. fruticosus (p. 76), diaphragms of the typical generic configuration and arrangement are confined almost entirely to monticular zooecia. Intermonticular zooecia in these species contain diaphragms that are generally planar and even spaced, giving no indication of generic affinities. The problem of the physiologic functions of the specialized zooecia in the monticules may never be solved because of the presumed extinction of the order near the end of the Paleozoic era. Nevertheless, the presence of important taxonomic characteristics in these zooecia makes the problem both intriguing and important in establishing a more natural classification of the Trepostomata.

The holotype of Paleschara reticulata Hall (1883, p. 179) described from the Hamilton group of York, New York, has a very thin incrusting zoarium. The zoarium displays the generic characters of Atactotoechus and the species is reassigned to that genus. The specimen is either so underdeveloped astogenetically that it does not possess characteristics of species described from the Hamilton group or it is a rare species that is not represented in later collections. Anomalotoechus tuberatus Duncan (1939, p. 188, pl. 1, figs. 1-3) and Discotrypa vera Duncan (1939, p. 264, pl. 4, figs. 1-3) are here placed in Atactotoechus because of their atactotoechid wall structure and curved and cystoidal diaphragms. ? Amplexopora spinulifera Fritz (1930, p. 224, pl. 12, figs. 3-6) is reassigned to Atactotoechus. The published illustrations show a strongly integrate tangential section with few acanthopores and a weak development of curved and cystoidal diaphragms. Cyphotrypa? maculosa Duncan (1939, p. 199 , pl. 5, figs. 17, 18) is placed in Atactotoechus with some doubt. The wall structure is atactotoechid but the diaphragms are not curved enough for a typical species of the genus.

The following species are now assigned to Atactotoechus :

acritus Boardman, n. sp.

bifoliatus Duncan 1939, p. 191, pl. 1, figs. 8-11

cartus Boardman, n. sp.

cartus Boardman, n. subsp.

pilatus Boardman, n. subsp.

casei Duncan 1939, p. 192, pl. 2, figs. 1-3.

creber Duncan 1939, p. 192, pl. 2, figs. 8-11.

fruticosus (Hall) 1877 (part) (Redescribed on p. 76) hunanensis Yang 1950, p. 4, pl. 1, figs. 1-4.

hystricosus Boardman, n. sp.

inornatus Boardman, $\mathrm{n}$. name

limbatus Duncan 1939, p. 193, pl. 2, figs. 4-7.

lui Yang 1950, p. 5, pl. 1, figs. 5-7.

maculosus (Duncan) 1939.

parallelus Boardman, n. sp.

reticulatus (Hall) 1883.

spinuliferus (Fritz) 1930

spissus Duncan 1939, p. 195, pl. 3, figs. 1-4.

tuberatus (Duncan) 1939.

typicus Duncan 1939, p. 196, pl. 3, figs. 5-11.

verus (Duncan) 1939.

winchelli (Ulrich) 1890 , p. 408 , pl. 45 , figs. 6, 6 a.

Inferred phylogenetic lineages in Atactotoechus.Only New York species are considered in the construction of a phylogeny for the Hamilton species of Atactotoechus, as not enough is known of the genus from other depositional areas. A. acritus (p. 72) is a long ranging, stable species from which the other species of the genus seem to have evolved, either directly or indirectly (fig. 25).

The A. acritus-cartus lineage (fig. 25) is of interest because $A$. cartus (p. 73) is markedly different from any other species of the genus but seems to have evolved within the possibly short time represented by parts of the Ledyard and superjacent Wanakah shale members. Evidence for a direct connection between $A$. arcitus and $A$. cartus is fragmentary, but the appearance of the Ledyard member just preceding the first appearance of $A$. cartus of a specimen of $A$. acritus that in part developed the morphologic characteristics of $A$. cartus cartus is at least suggestive. The lineage is characterized by decreases in zooecial angle, width of the ephebic zone, and number of dia-

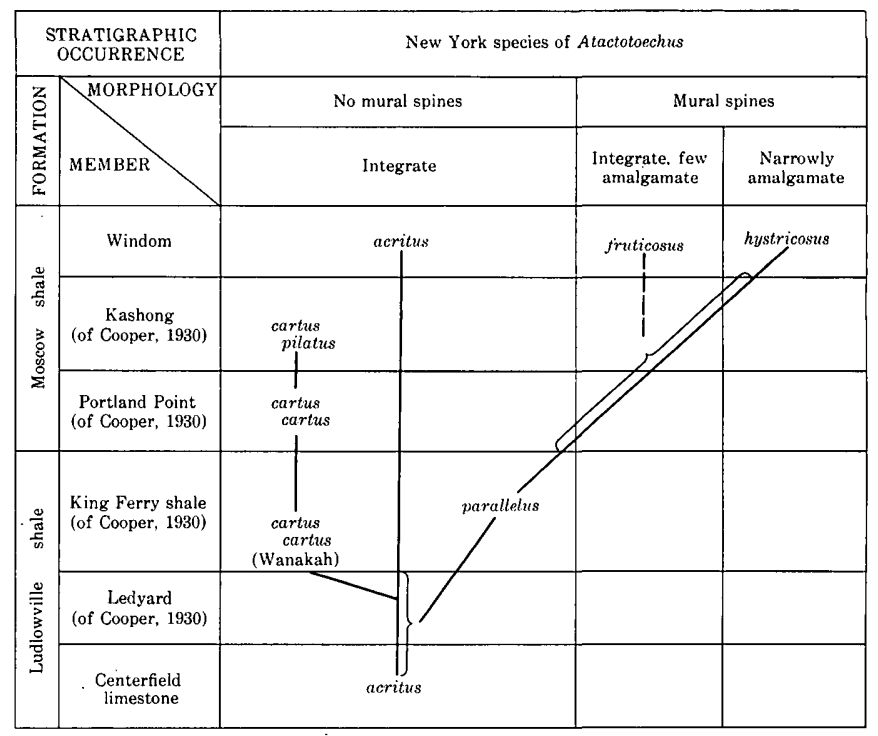

Figure 25.-Possible phylogenetic relationships of the New York species of the genus Atactotoechus. 
phragms. Between $A$. cartus cartus and $A$. cartus pilatus, the zooecial walls and diaphragms increase in thickness and the number of acanthopores decreases.

The A. acritus-hystricosus lineage includes the intervening species $A$. parallelus (p. 74) from the King Ferry shale member. In general, the lineage is morphologically comparable to the species of Atactotoechus described from the Skaneateles and Ludlowville equivalents of the Michigan Traverse section. The two groups of species are comparable in zooecial wall thicknesses, spacing and curvature of diaphragms, wide ephebic zones that have alternate thin- and thickwalled growth without the formation of basal laminae, and few or no acanthopores in intermonticular areas. In addition to these general similarities shared by the three New York species, the evidence for proposed phylogenetic connection within the New York forms concerns progressive changes rather than detailed characteristics possessed by all. The lineage displays a progressive increase in zooecial wall thickness and a decrease in the number of intermonticular acanthopores. The two oldest species, A. acritus and $A$. parallelus have comparable tangential sections, both appearing strongly integrate with subpolygonal apertures. However, the erratically curved and nonparallel dia- phragms of $A$. acritus change to parallel structures of more uniform curvature in $A$. parallelus. $A$. parallelus and $A$. hystricosis (p. 75) both display parallel diaphragms but the tangential sections of A. hystricosus change; the thicker zooecial walls appear narrowly amalgamate, apertures are subcircular, and acanthopores are limited to the monticules.

A scatter diagram (fig. 26) for the A. acritus-hystricosus lineage shows a shift to generally higher axial ratio values for similar growth stages as defined by the number of diaphragms. The bounding areas for each species show considerable overlap and this chart in itself could not serve to differentiate the species. Nevertheless, there is a shift in the same direction as the more pronounced shifts indicated for lineages in Leptotrypella (fig. 24) and Loxophragma (fig. 27).

The presence of mural spines and nodes on the diaphragms of both $A$. hystricosus and $A$. fruticosus creates a problem in taxonomic interpretation ( $p$. 76). The spines are limited to these two species of Atactotoechus, which are known only from the Windom member and are considered to be essentially contemporaneous.

If the spines originated by genetic changes, $A$. fruticosus most likely evolved from an unknown species

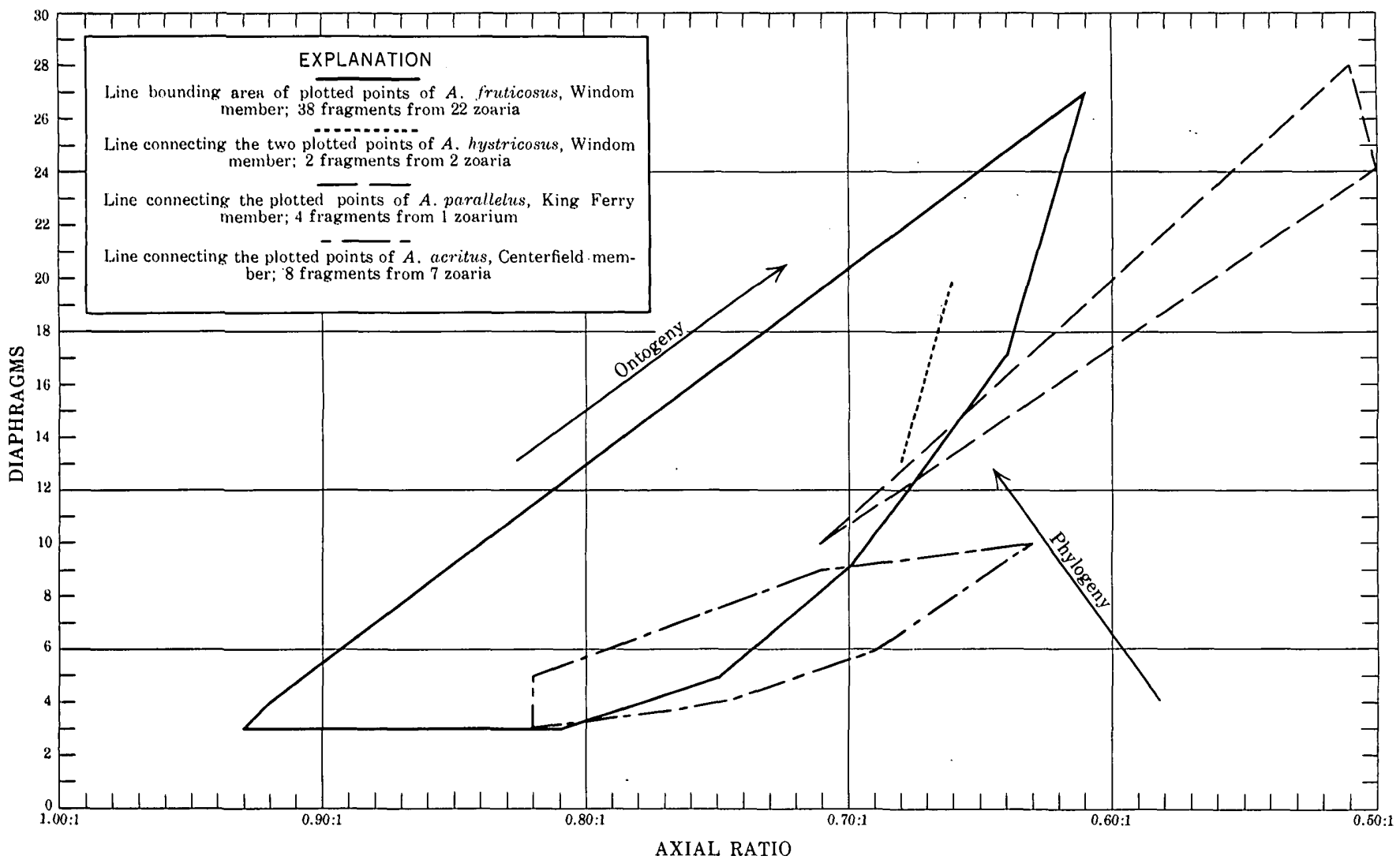

Figure 26.-Peripheral scatter diagram of spectes of Atactotoechus. 
or subspecies of the A. parallelus-hystricosus lineage within the time represented by the Portland Point and Kashong members. (For geographic and stratigraphic relationships see fig. 5). The major morphologic change that distinguishes $A$. fruticosus from the A. parallelus-hystricosus lineage is an increase in zooecial wall thickness. Independent development of an identical attribute would have to be postulated if A. fruticosus is interpreted as originating from another lineage.

Environmental control is a second, and perhaps the most plausible explanation for the development of spines in the two species. The phenotypic expression of the spines might have been controlled by the environment, to the extent that the spines were genetically possible within the genus earlier in Hamilton time but were not developed until Windom time because of a change in environment. Unfortunately, a detailed petrologic study of the inclosing rock has not been made and there is no known evidence for significant environmental change in the Windom. The third species of Atactotoechus occurring in the Windom member, A. acritus, is represented by only one fragment that does not show the spines and nodes.

\section{Atactotoechus acritus Boardman, n. sp.}

Plate 17, figures $1-5$

Diagnosis.-Ramose and incrusting Atactotoechus (branches 5 to $10 \mathrm{~mm}$ in diameter) with moderately low monticules; erratically curved and non-parallel diaphragms and cystoidal diaphragms in many zooecia; zooecial walls integrate; acanthopores abundant for genus.

Description.-Zoaria are ramose and incrusting and thin patchy layers of overgrowth occur on a few zoaria. Monticules are of low to medium height. Monticular zooecial walls are generally thicker than the walls of surrounding zooecia. Inclucled acanthopores are larger and more abundant than in intermonticular areas. They develop large central canals, and commonly inflect the walls of the megazooecia. Monticular mesopores are few and are variously shaped in cross section.

In the neanic region, the zooecia have straight walls and few diaphragms. Abandoned growing tips are indicated at irregular intervals along the branches by remains of ephebic zones that arch across the branches and display various degrees of resorption.

In the ephebic region, the zooecial walls are fairly thin and display numerous irregular flexures and small variations in thickness. Within the ephebic zone, there is some alternation of neanic and ephebic growth without formation of basal laminations between the two

types of growth. In longitudinal sections, the zooecial boundary is normally marked by a dark line or narrow irregularly serrated zone of overlapping laminae. A few zooecia show thin zooecial linings in discontinuous patches just distal to the thicker diaphragms. The well-developed parallelism of repeated curved and cystoidal diaphragms that is common in other species of the genus is lacking in many zooecia. In these zooecia, curved and cystoidal diaphragms are more nonparallel and erratic in curvature and give the species a typically disordered look in longitudinal sections. Enclosed compartments formed by the cystoidal diaphragms thus vary considerably in size and shape. True cystiphragms (pl. 17, fig. 5) are very rare; only one zooecium displays them in each of 3 of the 18 zoaria studied. Diaphragms and cystiphragms are generally thin but show an appreciable variation in thickness. Compound diaphragms are rare.

In tangential view, zooecia have polygonal to subpolygonal apertures. The zooecial walls are integrate, the zooecial boundaries light to transparent. Some zooecia appear amalgamate because the straight laminae intersect the boundaries at high angles. Close inspection however, reveals the transparent sharply defined zooecial boundary, making the zooecia integrate by definition. Acanthopores are unusually numerous in intermonticular areas, and inflect the zooecial walls if located between zooecial corners. Mesopores are rare outside of the monticules. Curved and cystoidal diaphragms are commonly seen as loops in the voids of the zooecia in tangential sections.

The following table is based on 13 sectioned fragments from 12 zoaria. Sections from 18 zoaria of A. ccritus were examined.

Diameter of zoarium ..............

Width of neanic zone......... do....

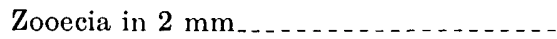
Average diameter of zooecia per zoarium_........................

Diameter of megazooecia . . . . do . .

Acanthopores per zooecium_........ Diaphragm ratio

Ontogeny
Average number of diaphragms

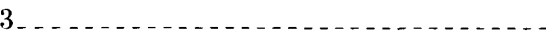

5._.

6._.

7_ _

9

10

Remarks.-Two ramose fragments of $A$. acritus were collected from the Ledyard member. One of the atio - 82 74
72 .72
.71 63

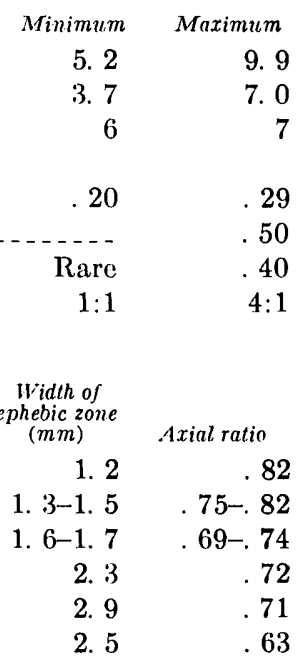

7 $4: 1$ 
specimens is comparable with the holotype. Part of the longitudinal section of the second specimen (pl. 17, fig. 2) is typical of $A$. acritus, but other parts of the section closely resemble $A$. cartus cartus. The only ramose specimen from beds younger than the Ledyard is a fragment from the Windom member that is morphologically similar to the holotype of $A$. acritus except for a scarcity of acanthopores. For further discussion see p. 70).

A. acritus differs from Atactotoechus creber Duncan (1939, p. 192, pl. 2, figs. 8-11) in displaying less parallelism of diaphragms, more strongly curved diaphragms and cystoidal diaphragms, fewer diaphragms in the neanic region, and apertures that are more strongly polygonal. Atactotoechus spissus Duncan (1939, p. 195 , pl. 3 , figs. 1-4) differs from $A$. acritus in possessing regularly spaced diaphragms throughout the neanic region. 4. acritus differs from Atactotoechus typicus Duncan (1939, p. 196, pl. 3, figs. 5-11) in the different growth habit and less well developed parallelism of the diaphragms.

Types: Holotype USNM 133926 from USGS collection 3561-SD ; figured paratypes USNM 133927-133930.

Occurcince: Ludlowville shale: Centerfield limestone member, USGS-SD 3503, 3529, 3561, 3571, 3593; Ledyard member of Cooper (1930), USGS 3541-SD; Wanakah shale member as used by Buehler and Tesmer (in press), USGS 3516-SD, USNM collection 1017. Moscow shale: Windom member, USGS 3559-S.D. Localities range from Lake Erie to Cayuga Lake.

Atactotoechus cartus Boardman, n. sp.

Plate 18, figures 1-6

Diagnosis.-Polytypic species of small ramose zoaria (maximum observed diameter of branches $9.3 \mathrm{~mm}$ ) characterized by unusually low zooecial angles, narrow ephebic zones, and few diaphragms; curved and cystoidal diaphragms typical of the genus largely restricted to zooecia of monticules, intermonticular diaphragms generally planar and parallel.

Remarks.-Two chronological subspecies are recognized within $A$. cartus, $A$. cartus cartus from the Wanakah shales member and Portland Point member and A. cartus pilatus from the Kashong member overlying the Portland Point member. The two subspecies have morphologic characters primarily low zooecial angles, narrow ephebic zones and few diaphragms, that are greatly different from the other known species of Atuctotoechus. The morphologic uniqueness and stratigraphic relationships indicate a direct phylogenetic connection between the two taxa.

Type: Holotype USNM 133935 from USGS collection 3551-SD.

Occurrence: Wanakah shale member (as used by Buebler and Tesmer in press) of the Ludlowville shale and the Port- land Point and Kashong member (of Cooper, 1930) of the Moscow shale from the Buffalo quadrangle to Seneca Lake. (For complete listing of collection numbers see p. 74).

Atactotoechus cartus cartus Boardman, n. subsp. Plate 18, figures 4-6

Diagnosis.-Zoaria ramose; branches small, 3 to 9 $\mathrm{mm}$ in diameter; monticules generally high; zooecial angles unusually low, average $62^{\circ}$; diaphragms few (maximum of 12 observed) and generally thin, zooecial walls increase gradually in thickness in early ephebic zone.

Description.-The ramose zoaria form dense clumps. Conspecific overgrowth is rare. Monticules are generally high. The included megazooecia have slightly thicker walls, and generally have a few more diaphragms than intermonticular zooecia. The monticular diaphragms tend to be planar and parallel, inclined to each other and irregularly curved, or parallel and regularly curved, Cystoidal diaphragms are abundant in the monticules. Monticular mesopores are very rare and acanthopores show little increase in number or size over intermonticular acanthopores.

The zooecia reach the surfaces of the zoaria at unusually low angles, averaging approximately $62^{\circ}$ instead of the usual $80^{\circ}-90^{\circ}$ for the genus. No definite zooecial bend is developed. 'The most advanced growth stages show relatively few diaphragms (maximum observed is 12) and narrow ephebic zones for a species of Atactotoechus. In most zooecia the zooecial walls increase gradually in thickness in the early ephebic zone. After the third or fourth diaphragm the wall thickness may continue to increase slowly or become irregular. The zooecial walls are typically atactotoechid (p. 32). In longitudinal sections, the zooecial boundaries are marked by light or black lines or narrow serrated zones of overlapping laminae. The light or dark shading of the boundaries may be discontinuous along any one boundary. Planar and parallel diaphragms are the rule in the early ephebic zones and occur throughout many intermonticular zooecia. Curved and cystoidal diaphragms are common in other zooecia after the fourth or fifth diaphragm but are not generally as strongly curved as the diaphragms of the zooecia in the monticules. The diaphragms are generally thin, but a few are conspicuously thick.

In tangential view, the zooecia have polygonal to subpolygonal apertures. The zooecial walls are integrate, the zooecial boundaries appearing as almost invisible light lines. Acanthopores are variable in number within a zoarium, and in a few sections are unusually numerous for the genus. The acanthopores have a well-defined central tube, and ordinarily occur in the zooecial corners. Mesopores are rare to absent. 
The following table is based on 152 sectioned fragments from 13 zoaria. Sections from 15 zoaria of $A$. cartus cartus were examined.

\begin{tabular}{|c|c|c|}
\hline & Minimum & Maximum \\
\hline Diameter of zoarium & 2. 8 & 9. 3 \\
\hline 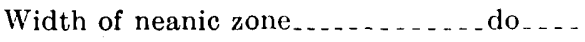 & 2. 3 & 7. 8 \\
\hline Zooecial surface angle $\ldots \ldots$ & $32^{\circ}$ & $86^{\circ}$ \\
\hline Zooecia in $2 \mathrm{~mm}$ & 5 & 7 \\
\hline \multicolumn{3}{|l|}{ Average diameter of zooecia per fragment } \\
\hline . $\mathrm{mm}_{-}$ & .17 & 26 \\
\hline Diameter of megazooecia $\ldots \ldots \ldots$. & ....... & 50 \\
\hline Acanthopores per zooecium & Very rare & 60 \\
\hline Mesopores per zooecium & Very rare & 20 \\
\hline \multicolumn{3}{|l|}{ Ontogeny } \\
\hline Aterage number of diaphragms & $\begin{array}{l}\text { Width of } \\
\text { ?phebic zone } \\
(\mathrm{mm})\end{array}$ & Axial ratin \\
\hline $1-3 \ldots$ & $.4-.9$ & $.78-.93$ \\
\hline $4 \ldots$ & $.8-1.2$ & $.75-.83$ \\
\hline 5 & $.9-1.5$ & $.71-.84$ \\
\hline 7 & 1. $2-1.6$ & $.69-.79$ \\
\hline 9 & 1. 6 & .71 \\
\hline $11 \ldots$ & 1. 8 & .68 \\
\hline
\end{tabular}

Remarks.-Zoaria from the Portland Point member occur in isolated lens-shaped concentrations of broken fragments, each mass presumably representing one zoarium. (For further discussion see p. 36). In support of this assumption, all of the fragments of one of the concentrations displayed constant morphologic characteristics that were noticeably at variance with fragments from the other 12 concentrations. The variant zoarium possesses relatively well-defined zooecial bends, generally higher zooecial angles, longer living chambers, and a generally wider ephebic zone for any one growth stage as defined by numbers of diaphragms. Constancy of variant morphologic characteristics throughout the concentration of fragments suggests that only one zoarium is represented. Such constancy is expected in a zoarium if it can be assumed that all of the individuals of a colony possess the same genetic constitution and therefore display phenotypically most of the same variant morphologic characters.

Only one fragment was collected from the Wanakah shale member.

Types: Holotype USNM 133935 from USGS collection 3551-SD; figured paratypes USNM 133937, 133939.

Occurrence: Ludlowville shale: Wanakah shale member as used by Buehler and Tesmer (in press), USGS 3515-SD, Buffalo quadrangle. Moscow shale: Portland Point member of Cooper (1930), USGS 35n1-SD, Canandaigua Lake.

Atactotoechus cartus pilatus Boardman, n. subsp.

Plate 18, figures 1-3

Diagnosis.-Ramose subspecies differentiated from the nominate subspecies by many thick diaphragms causing abrupt increases in thickness of generally thick zooecial walls; monticules of low to medium height; maximum observed number of diaphragms 6 ; acanthopores small and rare, generally limited to monticules.

The major morphologic differences between $A$. cartus cartus and $A$. cartus pilatus are the thick development of both diaphragms and zooecial walls in $A$. cartus pilatus. A. cartus cartus displays thickened diaphragms and walls in random zooecia of a relatively few zoaria. These morphologic differences are considered marked and constant enough to be useful for distinguishing the Kashong shale member from lower members if a reasonable number of specimens are available. Except for generally fewer acanthopores in A. cartus pilatus (maximum acanthopore ratio: 0.32:1), no important differences were found between the subspecies in the quantitative measurements made.

The small numbers of diaphragms and the narrow ephebic zones of $A$. cartus pilatus are either characteristics of the subspecies or indicate that the material studied came from young zoaria or younger parts of zoaria. Ninety-three longtitudinal slides were studied from seven Kashong localities. The fragments sectioned were chosen at random. At Menteth Creek (Collection 3552) one compressed mound of fragments and branches of $A$. cartus pilatus mensured 4 feet in diameter and 6 inches in height. Due to the compressed condition of the mass and the hard enclosing matrix it was impossible to determine the number of zoaria represented. Pieces were collected from eight places in this mass and thin-sections were made from all 8 collections. The maximum number of diaphragms seen was five. Thus it seems that small numbers of diaphragms and narrow ephebic zones are characteristic of the subspecies. Sections from 45 zoaria were examined.

Types: Holotype USNM 133934 from USGS collection 3552-SD; figured paratypes USNM 133932, 133933.

Occurence: Kashong member (of Cooper, 1930) of the Moscow shale, LSGS-SD 3500, 3501, 3531, 3543, 3552, 3558 and collection (35). Localities range from the Attica quadrangle to Seneca Lake.

\section{Atactotoechus parallelus Boardman, n. sp. Plate 17, figure 6}

Diagnosis.-Zoaria large, ramose; in ephebic zone zooecial walls thin, diaphragms uniformly thin, parallel, generally planar to slightly curved, monticular diaphragms more strongly and irregularly curved; in tangential view zooecial walls strongly integrate.

Description.-Zoaria are ramose. Primary branches of the holotype zoarium are covered by a thick con- 
specific overgrowth. Monticules are high. Monticular zooecia have thickened walls and are irregular in shape as seen in tangential sections. Included diaphragms are more strongly and irregularly curved and more irregularly spaced than those of intermonticular zooecia. Monticular acanthopores are numerous, enlarged, and strongly inflect the zooecial walls. Individual monticules contain only 2 or 3 mesopores.

In the neanic region, zooecial walls are straight to irregularly flexed. Diaphragms occur in widely spaced zones arching across the neanic region. As many as 15 diaphragms, irregularly spaced, are displayed in a zooecium within an arched zone. Some zooecial wall thickening occurs opposite the more closely spaced diaphragms indicating positions of abandoned growing tips.

In the ephebic region, zooecial walls are thin and display numerous irregular flexures and small variations in thickness. Zooecial boundaries are marked by a dark line or narrow irregularly serrated zone of overlapping laminae. Diaphragms are uniformly thin, parallel, and generally planar to slightly curved. Cystoidal diaphragms are not common outside of the monticules. Cystiphragms and compound diaphragms are very rare.

In tangential view, zooecia have polygonal to subpolygonal apertures. The zooecial walls are strongly integrate; the zooecial boundary appears as a welldefined light to dark line. Acanthopores are rare between monticules, small, and not confined to zooecial corners. Intermonticular mesopores are very rare to absent.

The following table is based on 4 sectioned fragments from the only zoarium of $A$. parallelus available for study.

Diameter of zoarium ...............

Width of neanic zone............. . do ...

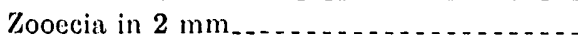

Average diameter of zooecia per fragment $\mathrm{mm}$. -

Diameter of megazooecia . . . . . . . do...

Acanthopores per zooecium.......... Very rare

\begin{tabular}{|c|c|c|}
\hline \multicolumn{3}{|l|}{ Ontogeny } \\
\hline Aeerage number of diaphragme & $\begin{array}{c}\text { Width of } \\
\text { ephebic zone } \\
(m m)\end{array}$ & Axial ratio \\
\hline ـ 10 & 2. 6 & .71 \\
\hline $15 \ldots$ & 3.8 & 65 \\
\hline $24 \ldots \ldots$ & 6. 6 & 50 \\
\hline $28 \ldots$ & 7. 6 & 51 \\
\hline
\end{tabular}

Remarlss.-Atactotoechus casei Duncan (1939, p. 192, pl. 2, figs. 1-3) differs from $A$. parallelus in its massive growth habit and low monticules containing acanthopores that do not noticeably inflect zooecial walls. A. casei has integrate walls with light zooecial boundaries. Atactotoechus creber Duncan (1939, p. 192, pl. 2, figs. 8-11) differs from $A$. parallelus in having narrowly amalgamate walls and extreme crowding of diaphragms in short zones opposite zooecial wall thickening in the ephebic region. Atactotoechus limbatus Duncan (1939, p. 193, pl. 2, figs. 4-7), A. spissus Duncan (1939, p. 195, pl. 3, figs. 1-4), and A. typicus Duncan (1939, p. 196, pl. 3, figs. 5-11) all have conspicuously thickened zooecial walls and diaphragms, differing mainly in this characteristic from $A$. parallelus.

Type: Holotype USNM 133931 from USGS collection 3564-SD.

Occurrence: King Ferry shale member (of Cooper, 1930) of the Ludlowville shale, USGS 3564-SD, Cayuga Lake.

Atactotoechus hystricosus Boardman, n. sp.

Plate 20, figures 1, 2

Diagnosis.-Zoaria ramose; in ephebic zone zooecial walls moderately thick and irregularly undulate; diaphragms planar to strongly curved and cystoidal, parallel, variable in thickness, many compound; small mural spines and nodes on distal sides of many diaphragms; in tangential view zooecial walls generally narrowly amalgamate, apertures subcircular to subpolygonal; acanthopores limited to monticules.

Description.-Zoaria are ramose. Conspecific overgrowth is common. Monticules are high. Monticular zooecial apertures are subtriangular to subpolygonal. Zooecial walls are thickened and generally integrate. Monticular diaphragms are either strongly curved forming repeated, parallel series of cystoidal diaphragms and a few cystiphragms, or planar, parallel, and closely spaced. Cystiphragms are very rare. Monticular acanthopores are few, small, generally at zooecial corners, and cause little inflection of zooecial walls. Mesopores are few and irregularly scattered in monticules.

In the neanic region, zooecial walls are straight to irregularly flexed. Few diaphragms occur in widely spaced zones arching across the neanic region.

In the ephebic region, zooecial walls are moderately thick and generally irregularly undulating as seen in longitudinal sections. Wall thickness is extremely irregular, commonly changing with the addition of thicker diaphragms. Wall thickness is further complicated by an alternation of thin- and thick-walled growth within the generally ephebic region. A basal lamination is not developed at the beginning of thinwalled growth as in the more common overgrowths. Zooecial boundaries are marked by a light to dark, narrow, irregularly serrated zone of overlapping 
laminae. Diaphragms range from planar to strongly curved and generally are arranged in parallel series within a zooecium. Cystodial diaphragms are common and similarly arranged. Diaphragms are moderately variable in thickness; thicker diaphragms are commonly compound. Small mural spines and nodes are abundant on the distal sides of many diaphragms but are rare on the zooecial walls.

In the tangential view, zooecia have subcircular to subpolygonal apertures. The zooecial walls are generally narrowly amalgamate. A few intermonticular zooecia and most of the monticular zooecia are integrate. Acanthopores are limited to the monticules. Mesopores are very rare. Interiors of the zooecia in tangential sections are characterized by the curved and cystoidal diaphragms that appear as semicircles of laminated material, and the minute spines on the diaphragms that appear as small circles and dots.

The following table is based on 4 sectioned fragments from the 4 available zoaria of $A$. hystricosus.

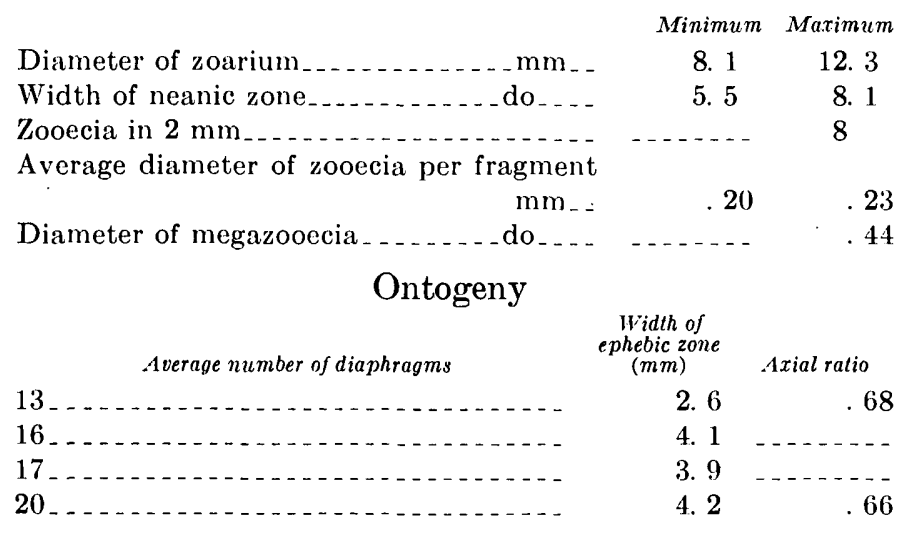

Remarks.-A. hystricosus and A. fruticosus are both limited to the Windom member of the Moscow shale and are the only known species of Atactotoechus displaying the small mural spines and nodes on the diaphragms. The apparently simultaneous appearance of a new attribute in two species of a genus creates a problem in phylogenetic interpretation (see p. 71).

Fundamental to the problem is the correctness of dividing the Windom material into two species. $A$. hystricosus differs from $A$. fruticosus in displaying thinner more undulating zooecial walls in the ephebic zones, more strongly curved diaphragms, narrowly amalgamate walls, and acanthopores limited to the monticules. A. hystricosus occurs only in the easternmost locality of the region studied and the range of morphologic variation is poorly known as the size of the sample is inadequate. A. fruticosus is not found in the easternmost locality but is very common in most of the other localities of the Windom member and is distinctive and well known. Specimens placed in $A$. fruticosus are relatively constant for the genus in morphologic characteristics and there are no known specimens that are transitional or even approach the morphologic characteristics of $A$. hystricosus.

Probably the most significant morphologic difference between the two groups is the narrowly amalgamate appearance of $A$. hystricosus as opposed to the generally integrate appearance of $A$. fruticosus. The complete range of variation of amalgamate or integrate appearance within a species is generally determinable in 2 or 3 randomly selected tangential sections. Thus, the amalgamate characteristic in $A$. hystricosus is fairly well established. Also, if specimens now placed in $A$. hystricosus were merely thin-walled variants of $A$. fruticosus, they would niost certainly be more strongly integrate as is the general rule in thin-walled variants of species of Atactotoechus. The narrowly amalgamate appearance of $A$. hystricosus therefore most likely indicates fundamental differences between the two groups in the pitch and configuration of the wall laminae. This difference in laminae is perhaps better interpreted as genetic rather than environmental and the two groups are thus considered separate species.

Types: Holotype USNM 133945 from USGS collection 3570-SD; figured paratype USNM 133946.

Occurrence: Windom member of the Moscow shale, USGS 3570-SD, Fillmore Glen State Park, Moravia quadrangle.

\section{Atactotoechus fruticosus (Hall) $\mathbf{1 8 7 7}$}

Plate 19, figures 1-6; plate 20, figures 3,4

1877. Chaetetes fruticosus Hall (part), New York State Geol. Survey, Paleontology, pl. 38, fig. 2.

1877. Chactetes furcatus Hall (part), New York State Geol. Survey, Paleontology, pl. 37, fig. 5.

1939. Atactotoechus fruticosns (Hall) Duncan, Univ. Michigan, Mus. Paleontology, Contr., v. 5, p. 190.

Diagnosis.-Zoaria large, ramose, and incrusting zooecial walls uniformly thick in ephebic zone; diaphragms thin, generally planar, parallel and evenly spaced in intermonticular zooecia, curved and cystoidal in monticules, small mural spines and nodes generally on distal sides of diaphragms in most zoaria; zooecia integrate, few narrowly amalgamate, apertures unusually small.

Description.-Zoaria are ordinarily ramose and rarely incrusting, or can be a combination of the two growth habits. Branches are large, ranging from 5 to $17 \mathrm{~mm}$ in diameter. Thick incrusting layers of conspecific overgrowth are common. The branches may display bulbous to irregular swellings, caused by concentrations of thicker layers of overgrowth or alternating zones of thick and thin zooecial walls that 
elongate the zooecia within the ephebic zone (see below). Monticules are variable in height, but most commonly are high. Included megazooecia have strongly thickened walls, and most display an irregular growth habit. Monticular diaphragms are strongly curved and cystoidal. As many as 5 or 6 polygonal mesopores occur within a monticule. Acanthopores in the monticules are increased in number and size over intermonticular acanthopores and some are inflected far into adjacent zooecial cavities as seen in tangential sections.

In the neanic region, zooecial walls are generally uncrenulated and straight. Diaphragms occur in irregularly spaced zones arching across the neanic region and probably indicate positions of abandoned growing tips. A few abandoned tips show no signs of resorption (pl. 19, fig. 4) but most have only the first 2 or 3 diaphragms remaining.

In the ephebic zone, specimens showing growth stages of 7 diaphragms or more generally have a zooecial angle of greater than $80^{\circ}$. Zones of thin zooecial walls that interrupt normal thick-walled development are common within the ephebic regions. A basal lamination is not developed at the beginning of this thin-walled growth as in the more common overgrowths. The thin walls within the ephebic zones generally retain a finely laminated structure similar to the thick walls, so do not completely lose their ephebic construction. In the extreme development, the thin-walled zones revert to neanic walls that are characteristically thin and granular and may extend locally to form a neanic zone for a secondary branch. Diaphragms are more widely spaced opposite the thin-walled zones.

If not complicated by alternate thick and thinwalled growth, the zooecial walls increase rapidly and uniformly in thickness in the early ephebic zone and are unusually thick for Atactotoechus. In most longitudinal sections the zooecial boundary is generally marked by a dark line or narrow, irregularly serrated zone of overlapping laminae. In a few specimens, zooecial boundaries are light in shading or are not definable, the laminae from adjacent zooecia appearing continuous. Diaphragms are commonly thin, many of the thicker diaphragms are compound. The majority of intermonticular diaphragms are planar to slightly curved, parallel, and evenly spaced. In a few zoaria curved and cystoidal diaphragms are common at the zooecial bends. The curved and cystoidal diaphragm development typical of the genus occurs more commonly in the monticular zooecia. Small mural spines and nodes appear on the diaphragms (pl. 20, figs. 4a, 4b) in most of the zoaria examined.
The spines occur most commonly on the distal sides of the thicker diaphragms, less commonly on the zooecial walls and very rarely on the proximal sides of the diaphragms. The spines are generally about equally distributed throughout a zoarium, and range from abundant to none in different zoaria.

In the tangential view zooecia have unusually small subpolygonal to subcircular apertures due to the thickened zooecial walls. The zooecial walls are generally integrate but a few appear narrowly amalgamate. The zooecial boundary is light to transparent and difficult to define, which may account for the narrowly amalgamate appearance of many zooecia. Acanthopores are rare outside the monticules and are confined to the corners of zooecia. The acanthopores are generally small but may cause slight inflection in the zooecial walls. Mesopores are very rare outside the monticules.

The following table is based on 40 sectioned fragments from 22 zoaria. Sections from 42 zoaria of $A$. fruticosus were examined.

\begin{tabular}{|c|c|c|}
\hline & Minimum & Maximum \\
\hline Diameter of zoarium ..... & 4. 9 & 16. 9 \\
\hline Width of neanic zone & 3.9 & 13. 2 \\
\hline Zooecial wall thickness & .04 & 12 \\
\hline Diaphragm ratio & $1: 1$ & $4: 1$ \\
\hline Zooecia in $2 \mathrm{~mm} \ldots \ldots$ & $6 \frac{1 / 2}{2}$ & $8^{1 / 1} / 2$ \\
\hline \multicolumn{3}{|l|}{ Average diameter of zooccia per fragment } \\
\hline Diameter of megazooccia $\ldots . . . .$. do $\ldots$ & .14 & $\begin{array}{l}23 \\
45\end{array}$ \\
\hline \multicolumn{3}{|l|}{ Ontogeny } \\
\hline Number of diaphragms & $\begin{array}{l}\text { Width of } \\
\text { ephebic zone } \\
(m m)\end{array}$ & Axial ratio \\
\hline 4 & $0.7-1.1$ & $.80-.93$ \\
\hline-6. & 1. $1-1.7$ & $72-.87$ \\
\hline-8 & 1. $8-2.0$ & $74-.81$ \\
\hline-10 & 1. $9-2.6$ & $70-.84$ \\
\hline $11-1$ & 2. 3-3. 7 & $67-.78$ \\
\hline & 3. $7-4.1$ & $64-.67$ \\
\hline - . . - _ & 4. 9 & .63 \\
\hline & 4. 8 & \\
\hline
\end{tabular}

Remarks.-Hall (1877, pl. 38, figs. 1-5) erected Chaetetes fruticosus, figuring three unsectioned syntypes and giving no written description. Duncan (1939, p. 190) reassigned C. fruticosus to Atactotoechus. Thin sections show that one of the syntypes (N YSM 6182, pl. 38, fig. 2) does belong to the genus Atactotoechus and this specimen is here designated as the lectotype of Atactotoechus fruticosus (Hall) 1877. The remaining two syntypes (Hall, pl. 38, figs. $1,5)$ are conspecific with Leptotrypella asterica (p. 58) and are considered only as identified specimens of L. asterica.

Sectioning of syntypes of Chaetetes furcatus Hall 1877 , revealed one specimen (NYSM 6186, pl. 37, fig. 
5) that is conspecific with the lectotype of $A$. fruticosus (Hall) and is now placed in A. fruticosus. For a more complete history of Atactotoechus fruticosus see p. 60 .

Types: Lectotoype NYSM no. 6182 (Hall, 1877, pl. 38, fig. 2) Hamilton group, Canandaigua Lake, New York; figured specimens USNM 133940-133944, 133947.

Occurrence: Windom member of the Moscow shale, USGS-SD 3548, 3553, 3559, 3562, 3569, 3575, 3579, 3585. Localities range from the Genesee Valley to Cayuga Lake.

\section{Atactotoechus inornatus Boardman, n. name}

1939. stigmatella hybrida Duncan, Univ. Michigan, Mus. Paleontology Cont., v. 5, p. 234, pl. 5, figs. 9-10.

Stigmatella hybrida Duncan 1939 , is a junior primary homonym of Stigmatella hybrida Dyer (1925, p. 71 , pl. 4 , figs. 7,8 , pl. 7, fig. 1), a species described from the Upper Ordovician of Ontario. At Miss Duncan's request, the specific name inornata is here substituted objectively for hybrida of Duncan. The type specimen bearing the new name inornata is interpreted to belong to the genus Atactotoechus Duncan 1939, thus the type of Stigmatella hybrida Duncan 1939 is now named Atactotoechus inornatus Broadman, n. name.

Remarks.-The holotype sections display strongly atactotoechid walls (p. 32). Diaphragms are generally parallel to each other and are not strongly curved. However, the diaphragms are few, which may indicate a young growth stage for the holotype. In addition to the utricular growth habit, incrusting forms of $A$. inornatus are known from the type locality in the Bell shale of Michigan. No representatives of the species were found in the New York Hamilton group.

Genus LOXOPHRAGMA Boardman, n. gen.

Type species.-Loxophragma lechrium Boardman, n. sp.

Diagnosis.-Zoaria ramose and incrusting, diaphragms typically planar to slightly curved, closely and irregularly spaced, non-parallel, both simple and compound; wall structure atactotoechid, integrate, rarely narrowly amalgamate; acanthopores laminated, small, variable in number; mesopores largely confined to monticules.

Description.-Zoaria are ramose, incrusting, or a combination of both habits. Ramose forms branch dichotomously. Conspecific overgrowth is generally present in varying amounts. Monticules are variable in height, evenly spaced in a zoarium, and contain megazooecia, zooecia, mesopores, and acanthopores in varying numbers.

The neanic region is nondiagnostic, displaying thin, granular walls that range from straight to tightly crenulated. In ramose forms, remnants of either eroded or resorbed growing tips are common.

In the ephebic zone, zooecial walls display an atactotoechid wall structure (p. 32). As seen in longitudinal sections the traces of the wall laminae approaching the zooecial boundaries generally remain straight and intersect the boundaries at angles of less than $90^{\circ}$. The zooecial boundary is generally narrow and well defined by the intersection of laminae, but in some individuals or species, laminae appear to be continuous across the boundary. The zooecial walls end distally in sharp edges controlled by the configuration of the laminae.

The diagnostic characteristics of the genus are found in the spacing and configuration of the diaphragms. Typically, diaphragms are closely and irregularly spaced, slightly inclined or nonparallel to each other, and planar to slightly curved. Relatively small, narrow, triangular (in two dimensions) compartments are commonly formed by the intersection of two adjacent nonparallel diaphragms. These triangular compartments are generally distinguishable from the rounded compartments formed by strongly curved cystoidal diaphragms that are characteristic of Atactotoechus (p. 69). Typical, closely packed nonparallel diaphragms occur either throughout a zoarium or are limited to the zooecia of the monticules. Species displaying the crowded nonparallel diaphragms only in the monticules have planar, more nearly parallel and evenly spaced diaphragms in intermonticular zooecia. Diaphragms are generally variable in thickness; the thicker diaphragms are commonly compound. Single nodes or thick short spines may occur on the distal sides of thicker diaphragms.

In tangential sections, zooecial walls are generally integrate with light, transparent zooecial boundaries. Narrowly amalgamate structure is rare. Acanthopores are laminated and small, and their numbers and distribution can be extremely variable within a zoarium or species. Mesopores are largely confined to the monticules.

Remarks.-Loxophragma is most closely related to the genus Atactotoechus and is placed in the same family grouping with that genus. Both genera are characterized by atactotoechid wall structure and close spacing of both simple and compound diaphragms. Atactotoechus is characterized by strongly curved cystoidal diaphragms arranged in parallel series within a zooecium. The diaphragms of Loxophragma are readily distinguishable from those of Atactotoechus, exhibiting a markedly disorderly nonparallelism and irregular spacing of planar to slightly curved diaphragms. 
Evidotrypella spinifera Duncan (1939, p. 218, pl. 7, figs. 6,7) and Eridotrypella valida Duncan (1939, p. 219, pl. 7, figs. 12-14) display an atactotoechid wall structure and the diaphragm arrangement of Loxophragma and are here reassigned to Loxophragma. Leptotrypella varia Iuncan $(1939$, p. 232 , pl. 10, figs. 1-3) has an atactotoechid wall structure. Microscopic examination of the holotype slide indicates the specimen is complicated by an atypical overgrowth. The side of the branch opposite the side figured by Duncan displays the primary zooecia containing diaphragms typical of Loxophragma, so L. varia is now placed in Loxophragma.

Inferred phylogenetic lineage in Loxophragma.Two species of Loxophragma are described in the New York Familton and quantitative evidence indicates phylogenetic connections between them. L. leptum (below) is the older species, occurring in the Centerfield limestone member. L. leptum is thought to give rise to $L$. lechrium, a species occurring in the Ledyard, Wanakah shale, and Tichenor limestone members and the partly equivalent King Ferry shale member of the Ludlowville shale, and the Kashong member of the Moscow shale. Evidence for the phylogenetic connection is found mainly in a three step increase in axial ratios for approximately equivalent growth stages (fig. 27). This increase correlates with stratigraphic position and parallels a similar increase in axial ratios in the same stratigraphic positions in the genera Leptotrypella (fig. 24) and Atactotoechus (fig. 26).

The increase in axial ratios is controlled by increase in neanic diameters, the major difference between the two species of Loxophragma. The increase in neanic diameter increases the total branch diameter of $L$. lechrium but there is little difference in the ephebic zone dimensions for any one growth stage in the two species. Thus, axial ratios of L. lechrium are considerably higher than those of $L$. leptum for any one growth stage. The intermediate position (fig. 27) of the three specimens of L. lechrium from the Ledyard member indicates that they are transitional between forms above and below, morphologically as well as in time. The Ledyard specimens probably could be considered a subspecies if adequate material were available. In addition to the increase in axial ratios and neanic diameters, the lineage shows an increase in the height of monticules and an apparent ability to develop to more advanced growth stages as determined by the numbers of diaphragms.

Loxophragma leptum Boardman, n. sp.

Plate 21, figures $5-8$

Diagnosis.-Small ramose Loxophragma (maximum diameter of branches about $4 \mathrm{~mm}$ ) with low monticules; distinguished by its small axial ratio and more

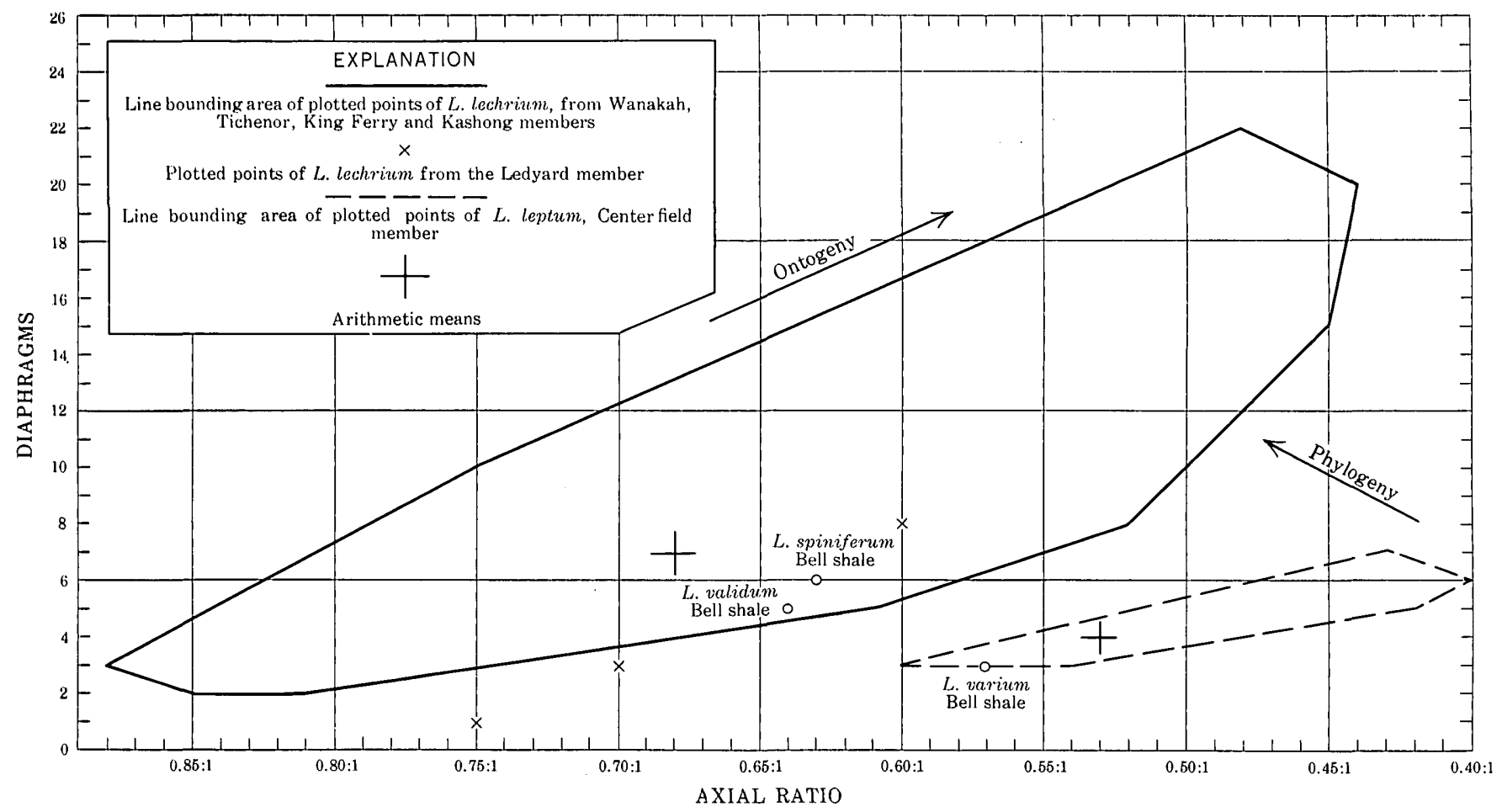

Figure 27.-Peripheral scatter diagram of the New York species of Loxophragma and individual measurements of the holotype sections of species described by Duncan (1939) from the Traverse group of Michigan and reassigned to Loxophragma. 
nearly parallel, less cystoidal diaphragms in intermonticular parts of zoarium.

Description.-Zoaria are small and ramose, and overgrowth is rare. Monticules are low and include several megazooecia, zooecia, and 2 or 3 mesopores. Some megazooecia have thickened walls. Acanthopores are always present in the monticules and are not appreciably larger than those in intermonticular regions.

In the ephebic zone, zooecial walls increase in thickness uniformly and attain their maximum thickness distal to the zooecial bend. Zooecial boundaries are light in shading and poorly defined in longitudinal views. Diaphragms are variable in thickness; thicker diaphragms are commonly compound. Diaphragms are generally planar and closely spaced. Many are inclined to each other and form compartments of various shapes, especially in the zooecia of the monticules. Intermonticular zooecia display diaphragms more nearly parallel to each other.

In the tangential view, apertures are subcircular in thicker walled zooecia, subpolygonal in thinner walled zooecia. Walls in tangential sections are typically integrate, rarely narrowly amalgamate. Acanthopores are extremely variable in number, small, possess welldefined central tubes, and are generally located at the zooecial corners.

The following table is based on 13 sectioned fragments from the 10 available zoaria of L. leptum.

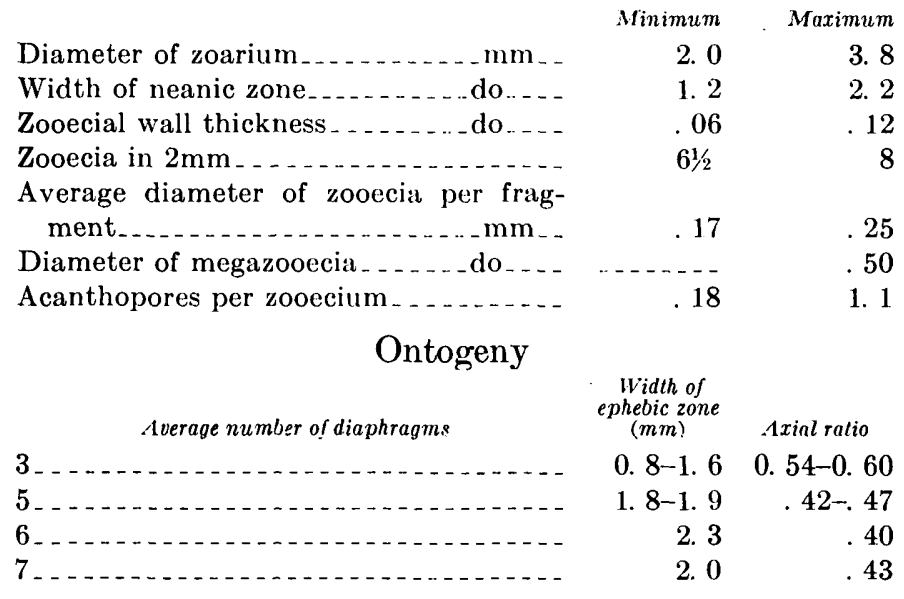

Remarks.-Specimens from locality 3561 differ somewhat from specimens from locality $275 \mathrm{~A}$, but considering the inadequate number of specimens from each locality and the several characteristics shared by both groups, both collections are included under one species. Material from locality 3561 has slightly thinner walls, sharper zooecial bends, and markedly fewer acanthopores. Wall thickness may very well have been environmentally controlled and the variation in the number of acanthopores (1.1:1 to $0.50: 1$ for locality $275 \mathrm{~A}$ and $0.20: 1$ to $0.18: 1$ for locality 3561 ) is possible within a species (compare with the well represented species, L. lechrium. Otherwise, both groups now included in L. leptum are comparable; axial ratios for equal growth stages are considered to be phylogenetically significant (fig. 27 and p. 79) and are thought to indicate that both groups are at the same stage of evolutionary development.

L. leptum and $L$. varium (Duncan) (1939, p. 232, pl. 10, figs. 1-3) differ in the microstructure of the zooecial walls and size of the acanthopores. $L$. varium has complex walls as described and considered diagnostic by Duncan and the acanthopores of the species are much larger in diameter, a characteristic that is fairly constant for a species.

Types: Holotype USNM 133952 from USGS collection 3561-SD ; figured paratypes USNM 133953-133955.

Occurrence: Centerfield limestone member of the Ludlowville shale, USGS 3561-SD, USNM collection $275 \mathrm{~A}$, from Seneca Lake and the Batavia quadrangle.

Loxophragma lechrium Boardman, n. sp.

Plate 21, figures 1-4; plate 22, figures 1-6

Diagnosis.-Ramose and incrusting Loxophragma (branches 3 to $9 \mathrm{~mm}$ in diameter) with moderately high monticules; nonparallel and cystoidal diaphragms occur throughout most zoaria.

Description.-Zoaria are ramose, incrusting or a combination of both habits. Conspecific overgrowth is common, ranging from many thin layers to one thick layer. Monticules are generally high and typically contain megazooecia with thickened walls, a few mesopores, and enlarged acanthopores that generally cause strong inflection of the zooecial walls.

The neanic region exhibits remnants of abandoned growing tips indicating partial resorption, and many eroded tips covered by subsequent incrusting-ramose overgrowth. Zooecial walls range from straight to crenulate.

In the ephebic zone, zooecial wall thickness is variable within a zooecium and is largely controlled by additions of large numbers of laminae from closely and irregularly spaced thick diaphragms. In zooecia having a number of thick diaphragms the laminae may form a distinguishable zooecial lining as they join and become part of the zooecial walls. The zooecial walls otherwise are strongly atactotoechid (p. 32). Zooecial boundaries are narrow and well defined by the intersection of laminae, many of which appear continuous across the boundary as seen in longitudinal sections. Diaphragms are typically unevenly crowded, nonparallel and planar to irregularly 
curved throughout a zoarium. Closed compartments are formed by closely spaced, nonparallel, nearly planar diaphragms and a few strongly curved cystoidal diaphragms. Diaphragms are extremely variable in thickness, and many of the thicker diaphragms are compound. A few atypical zoaria display some intermonticular zooecia that contain planar, parallel, and evenly spaced diaphragms. (See Remarks, below). Single rounded nodes or thick stubby spines occur on the distal sides of a few thick compound diaphragms.

In the tangential view, zooecial apertures are generally polygonal to subpolygonal. Most zooecial walls are integrate but a few are narrowly amalgamate in a rare zoarium or in exceptionally thick walls of megazooecia. Within a zoarium the number of acanthopores is erratic, ranging from very rare to nearly one per zooecium. Acanthopores are not restricted to the corners of zooecia and are small, causing varying inflection of the zooecial walls. A few mesopores are scattered erratically in intermonticular regions and many display noticeably thickened walls.

The following table is based on 58 sectioned fragments from 48 zoaria. Sections from more than 110 zoaria of $L$. lechrium were examined.

\begin{tabular}{|c|c|c|}
\hline & Minimum & махітит \\
\hline Diameter of zoarium $\ldots . . . . . . . .$. & 2.8 & 9. 2 \\
\hline Width of neanic zone........... do .... & 1.8 & 7. 3 \\
\hline Zooecial wall thickness.......... do .... & .03 & .13 \\
\hline Zooecia in $2 \mathrm{~mm}$ & 6 & 8 \\
\hline verage diameter of zooecia per frag- & & \\
\hline ment__. & .20 & .27 \\
\hline iameter of megazooecia_....... do_... & $\ldots \ldots$ & .55 \\
\hline canthopores per zooecium & Very rare & 82 \\
\hline \multicolumn{3}{|l|}{ Ontogeny } \\
\hline Average number of diaphragms & $\begin{array}{l}\text { Width of } \\
\text { ephebic zone } \\
(\mathrm{mm})\end{array}$ & Arial ratio \\
\hline 1 (Ledyard specimen) & 0.7 & .75 \\
\hline מ & $.6-.8$ & $.81-.85$ \\
\hline ( n & $.6-1.3$ & $.70-.88$ \\
\hline - & $.9-1.5$ & $.60-.86$ \\
\hline 5 & 1. $2-2.0$ & $.61-.79$ \\
\hline 6 & 1. 3-2. 1 & $.63-.72$ \\
\hline מ & 2. $0-2.3$ & $.63-.76$ \\
\hline ـ & 1. $6-2.3$ & $.52-.68$ \\
\hline 9 & 1. 9 & .70 \\
\hline 10 & 1. 8 & $.61-.75$ \\
\hline 12 & 2. $4-2.7$ & $.60-.62$ \\
\hline 14 & 2. 0 & .55 \\
\hline 15 & 2. $5-3.3$ & $45-.55$ \\
\hline 20 & 3. 9 & .44 \\
\hline ................... & 4. 0 & .48 \\
\hline
\end{tabular}

Remarks.-Specimens displaying parallel, evenly spaced diaphragms in the intermonticular zooecia are limited to the silty King Ferry shale member at Cayuga Lake and the Wanakah shale and Kashong members at Seneca Lake. Comparable parallelism of diaphragms is not consistent in the one incomplete zoarium from the King Ferry member for which several longitudinal sections were available. Two of the sections displayed parallel evenly spaced diaphragms, one was intermediate, and the fourth section contained the nonparallel, unevenly crowded diaphragm arrangement typical of the species. Also, in the collections containing zooecia with parallel diaphragms, twelve fragmentary zoaria, all represented by single longitudinal sections, displayed the parallelism, while five zoaria were typically nonparallel and six appeared transitional. Zoaria displaying the parallel diaphragms could be considered ecologic variants in response to changing environmental conditions close to the eastern limit of trepostome occurrence in the Hamilton group. The difference in diaphragm arrangement is not considered constant enough for species designation.

The three specimens now placed in L. lechrium from the Ledyard member are intermediate between $L$. leptum and L. lechrium both in stratigraphic position and quantitative characteristics (fig. 27) and probably could be considered as a linking subspecies in the $L$. leptum-lechrium lineage if more specimens were available.

L. lechrium differs from L. spiniferum (Duncan) (1939, p. 218, pl. 7, figs. 6,7 ) in having a strongly atactotoechid wall. The walls of $L$. spiniferum as they appear in the holotype section consist of laminae that are somewhat curved as they approach the zooecial boundary and the tangential view is amalgamate. Thus, L. spiniferum appears to be transitional between the atactotoechid and leptotrypellid walls. Also, the acanthopores of $L$. spiniferum are extremely abundant (1.2 acanthopores per zooecium) large, and limited to the zooecial corners.

L. validum (Duncan) (1939, p. 219, pl. 7, figs. 12-14) displays smaller more subcircular apertures (average $0.17 \mathrm{~mm}$ in diameter) than $L$. lechrium and diaphragms that are uniformly thin.

Types: Holotype USNM 133958 from USGS collection 3518-SD ; figured paratypes USNM 133948-133951, 133956, 133957, 133959-133961.

Occurrence: Ludlowville shale: Ledyard member of Cooper (1930), USGS 3541-SD; Wanakah shale member as used by Buehler and Tesmer (in press), USGS-SD 3502, 3505, 3509, 3511,3512 , 3513, 3514. 3515, 3516, 3518, 3524, 3526, 3532, 3547, 3555, 3558a, 3565; Tichenor limestone member, USNM collections 250B, 260C; King Ferry shale member of Cooper (1930), USGS-SD 3564, 3581. Noscow shale: Kashong member of Cooper (1930), USGS-SD 3500, 3558. Localities range from Lake Erie to Cayuga Lake. 


\section{LITERATURE CITED}

Bassler, R. S., 1911a, The early Paleozoic Bryozoa of the Baltic Provinces: U. S. Natl. Mus. Bull. 77, 382 p., 13 pls., 226 text figs.

1911b, The fossils and stratigraphy of the Middle Devonic of Wisconsin, by Herdman F. Cleland, Chapter V: Wisconsin Geol. and Nat. History Survey, Sci. ser. 6, Bull. 21, p. 49-67, pls. 5-11.

1923, American Silurian formations: Maryland Geol. Survey, Silurian, p. 233-270, 8 figs.

1934, Bryozoa (Generum et genotyporum index et bibliographia), Fossilium catalogus, I: Animalia, Pars 67, 229 p.

-1953, Treatise on invertebrate paleontology, Pt. G, Bryozoa: Geol. Soc. America and Univ. Kansas Press, p. G1-G253, 175 figs.

Buehler, E. J. and Tesmer, I. H., in press, The geology of Erie County: 'Buffalo Soc. Nat. Sciences.

Clarke, J. M., 1894, The succession of the fossil faunas in the section of the Livonia salt shaft: New York State Mus. Ann. Rept. 47, p. 325-352.

Cleland, H. F., 1903, A study of the fauna of the Hamilton Formation of the Cayuga Lake section in central New York: U. S. Geol. Survey Bull. 206, p. 13-112, 5 pls., 3 figs.

Cooper, G. A., 1930, Stratigraphy of the Hamilton group of New York: Am. Jour. Sci., 5th ser., v. 19, p. 116-134, 214236, 6 figs.

- chm. 1942, Correlation of the Devonian sedimentary formations of North America: Geol. Soc. America Bull. v. 53, p. 1729-1793, 1 pl., 1 fig.

Crockford, Joan, 1941, Bryozoa from the Silurian and Devonian of New South Wales: Royal Soc. New South Wales Jour. and Proc., v. 75 , p. 104-114, pl. 5, 1 text fig.

Cumings, E. R., 1902, A Revision of the bryozoan genera Dekayia, Dekayella, and Heterotrypa of the Cincinnati Group : Am. Geologist, v. 29, p. 197-218, pls. 9-12.

1904, Development of some Paleozoic Bryozoa : Am. Jour. Sci., 4 th ser., v. 17 , no. 97 , p. 49-78, figs. $1-83$.

- 1912, Development and systematic position of the monticuliporoids: Geol. Soc. America Bull. 23, p. 357-370, pls. 19-22.

Cumings, E. R. and Galloway, J. J., 1915, Studies of the morphology and histology of the Trepostomata or monticuliporoids: Geol. Soc. America Bull. 26, p. 349-374, pls. 10-15.

Dollfus, G. F., 1875, Observations critiques sur la classification des Polypiers paleozoiques: Acad. Sci. Paris Comptes rendus, v. 85 , p. 681-683.

Duncan, Helen, 1939, Trepostomatous Bryozoa from the Traverse group of Michigan: Contr. Mus. Paleont., Univ. Michigan, v. 5, no. 10, p. 171-270, pl. 1-16.

-1949, Genotypes of some Paleozoic Bryozoa: Washington Acad. Sci. Jour., v. 39, no. 4, p. 122-136.

-1957, Annotated bibliography of bryozoan paleoecology, in. Ladd, H. S., ed., Treatise on marine ecology and paleoecology, v. 2 : Geol. Soc. America Mem. 67, p. 783-799.

Jyer, W. S., 1925, The paleontology of the Credit River section: Ontario Dept. Mines Ann. Rept. 32, v. 32, pt. 7, 1923, p. 47-88, 7 pls.

Ehrenberg, C. G., 1831, Symbolae physicae, seu icones et descriptiones mammalium, avium, insectorum et animalium evertebratorum : Pars Zoologica, IV, Dec. I, Berlin (folio).
Elias, M. K., 1956, Life cycle and evolution of Bryozoa [abs]: Geol. Soc. America Bull. 67, p. 1691.

Fritz, M. A., 1930, Two new species of fossils from the Paleozoic rocks of Ontario: Royal Canadian Inst. Trans., v. 17 , pt. 2 , no. 38 , p. 223-225, pl. 12 .

1944a, Upper Devonian Bryozoa from New Mexico: Jour. Paleontology, v. 18, no. 1, p. 31-41, 2 pls.

1944b, Bryozoa indicate Middle Devonian age for Gaspe sandstone: Royal Soc. Canada Proc. and Trans., 3d ser., v. 38 , sec. IV, p. $35-38$, pl. 1 .

1951, Genus Trachytoechus from the Helderberg of Schoharie, N. Y. : Wagner Free Inst. Sci. Bull., v. 26, no. 4, p. $27-30$; pl. $1-2$.

Girty, G. H., 1911, New genera and species of Carboniferous fossils from the Fayetteville shale of Arkansas: New York Acad. Sci. Annals, v. 20, no. 3, pt. 2, p. 189-238.

Grabau, A. W., 1899, Geology and paleontology of Eighteen Mile Creek and the lake shore sections of Erie County, New York, Pt. II, Paleontology: Buffalo Soc. Nat. Sci. Bull., v. 6 (Bryozoa), p. 136-139, figs. 20-22; p. 158-179, figs. 47-77A.

-1917, Stratigraphic relationships of the Tully limestone and the Genesee shale in eastern North America: Geol. Soc. America Bull., v. 28, p. 945-958, 3 figs.

Hall, James, 1858, Report on the Geological Survey of the State of Iowa, embracing the results of investigations made during 1855, 1856, and 1857, v. 1, pt. 2, Paleontology (Bryozoa ), p. 651-653, pl. 22.

-1877, Illustrations of Devonian fossils: Corals of the Upper Helderberg and Hamilton Groups: New York State Geol. Survey, Paleontology, pls. i-xxxix and expl.

-1879, Corals and Bryozoans of the Lower Helderberg Group: New York State Mus. Ann. Rept. 32, p. 141-176.

-1883, Bryozoans of the Hamilton Group: Albany Inst. Trans., v. 10, p. 179-197.

1884, Bryozoans of the Hamilton Group: New York State Geologists Annual Rept. for 1883, 61 p.

Hall, James, and Simpson, G. B., 1887, Corals and Bryozoa : Text and plates containing descriptions and figures from the Lower Helderberg, Upper Helderberg, and Hamilton Groups: New York State Geol. Survey, Palaeontology, v. 6, xxxvi plus 298 p., 66 pls.

Lee, G. W., 1912, The British Carboniferous Trepostomata: Great Britain Geol. Survey Mem., v. 1, pt. 3, p. 135-195, pls. 14-16.

Lindstrom, Gustav, 1876, On the Affinities of the Anthozoa Tabulata: Annals and Mag. Nat. History, ser. 4, v. xviii, p. 1-17.

McNair, A. H., 1942, Upper Devonian Bryozoa: Jour. Paleontology, v. 16 , no. 3 , p. $343-350$, pls. $45-49$.

Miller, S. A., 1889, North American Geology and Paleontology: Cincinnati, 664 p., 1194 figs. in text.

Newell, N. D., 1949, Phyletic size increase, an important trend illustrated by fossil invertebrates: Evolution, vol. 3, no. 2 , p. 103-124, 6 figs.

Nicholson, H. A., 1874a, Descriptions of new fossils from the Devonian formations of Canada: Geol. Mag., dec. II of new series, v. I, p. 54-60, pl. 4.

- 1874b, Paleontology of the Province of Ontario, Chapter 2, Toronto, Canada.

-1876, Notes on the Palaeozoic corals of the State of Ohio: Annals and Mag. Nat. History, ser. 4, v. 18, p. 85-94, pl. 5 . 
Nicholson, H. A., 1879, On the structure and affinities of the "Tabulate Corals" of the Palaeozoic period, with critical descriptions of illustrative species: IEdinburgh, 1879, $342 \mathrm{p}$, 1.5 pls.

-1881, On the structure and affinities of the genus Monticulipora and its subgenera, with critical descriptions of illustrative species: Edinburgh, 240 p., $6 \mathrm{pls}$.

Nicholson, H. A. and Iydekker, Richard, 1889, Manual of palaeontology, v. I : Edinburgh and London, p. 346-360.

Nickles, J. M. and Bassler, R. S., 1900, A synopsis of American fossil Bryozoa, including bibliography and synonymy: U. S. Geol. Survey Bull. 173, 663 p.

Rich, J. I., 1951, Three critical environments of deposition, and criteria for recognition of rocks deposited in each of them: Geol. Soc. America Bull., v. 62, p. 1-20, 2 figs., 4 pls.

Rominger, Carl, 1866, Observations on Chaetetes and some related genera, in regard to their systematic position, with an appended description of some new species: Acad. Nat. Sci. Philadelphia Proc., p. 113-123.

Schuchert, Charles, 1955, Atlas of paleogeographic maps of North America: New York, John Wiley and Sons, 177 p., 84 figs.

Simpson, G. B., 1897, A handbook of the genera of the North American Palaeozoic Bryozoa, with an introduction upon the structure of living species: New York State Geologist Ann. Rept. 14, p. 407-608, pls. A-E, i-xxv.

Smith, Burnett, 1916, The structural relations of some Devonian shales in central New York: Acad. Nat. Sci. Philadelphia Proc., vol. 67, p. 561-569.

Stach, I. W., 1935, Growth Variation in Bryozoa Cheilostomata: Anmals and Mag. Nat. History, v. 16, ser. 10, p. 645-647.

-1937, The application of the Bryozoa in Cainozoic stratigraphy: Australiau and New Zealand Assoc. Adv. Sci., 23rd meeting. Auckland, January 1937, Rept., p. 80-83.

Stewart, G. A., 1927, Fauna of the Silica shale of Lucas County : Ohio Geol. Survey, 4th ser., Bull. 32, p. 1-76, 5 pls.

Sutton, R. G., 1951, Stratigraphy and structure of the Batavia quadringle: Rochester Acad. Sci. Proc., vol. 9, p. 348-408.

Thompson, J. V., 1830, Zoological researches and illustrations: On Polyzoa, a new animal discovered as an inhabitant of some Zoophites, with the description of the newly instituted genera Pedicellaria, Vesicularia, and their species: Mem. V, Cork, p. 89-102.
Ulrich, E. O., 1882, American Paleozoic Bryozoa: Cincinnati Soc. Nat. History Jour., v. 5, p. 121-175, pls. vi-viii.

-1890, Paleozoic Bryozoa: Illinois Geol. Survey, v. VIII, p. $285-688$, pls. xxix-lxxviii.

Ulrich, E. O., and Bassler, R. S., 1904, A revision of the Paleozoic Bryozoa, Pt. II, Trepostomata: Smithsonian Misc. Coll. (Quarterly Issue), v. 47, no. 1470, p. 15-55, pl. 6-14. 1913a, Systematic Paleontology of the Lower Devonian deposits of Maryland, Bryozoa: Maryland Geol. Survey, Lower Devonian, p. 259-290, pls. 41-52 (bound separately). 1913b, Systematic Paleontology of the Middle Devonian deposits of Maryland, Bryozoa: Maryland Geol. Survey, Middle and Upper Devonian, p. 123-124, pl. 7 (bound separately).

Vinassa de Regny, P., 1920, Sulla classificazions dei treptostomidi : Soc. italiana sci. nat. Atti, v. 59, p. 212-231.

Vine, G. R., 1884, Fourth report of the committee appointed for the purpose of reporting on fossil Polyzoa: British Assoc. Adv. Sci. 53d Mtg. Rept., p. 161-209.

Waagen, William and Wenzel, Joseph, 1886, Salt-Range Fossils: India Geol. Survey Mem, Palaeontologica Indica, Series XIII, Calcutta, p. 854-892, 904-924, 963-966, pl. cii-cxv.

Wells, J. W., 1947, Provisional paleoecological analysis of the Devonian rocks of the Columbus region: Ohio Jour. Sci., v. 47 , no. 3 , p. 119-126, 1 fig.

White, C. A., 1876, Description of new species of fossils from Paleozoic rocks of Iowa: Acad. Nat. Sci. Philadelphia Proc., 3d ser., v. 28, p. 27-34.

Winchell, Alexander, 1866, The Grand Traverse region; a report on the geological and industrial resources of the Counties of Antrim, Grand Traverse, Benzie and Leelanaw in the Lower Peninsula of Michigan-Appendix to a Report on the Grand Traverse Region, p. 83-97; Ann Arbor, Mich. Dr. Chase's Steam Printing House.

Yang, K. C., 1950, Some bryozoans from Upper Devonian and Lower Carboniferous of Hunan: Palaeont. Soc. China, Palaeontological Novitates no. 6, p. 1-14, 4 pls. (English with Chinese summary).

1954, The early Middle Devonian Bryozoans from Wutsun shale, Kwangsi, Acta Palaeontologica Sinica, v. 2, no. 2, p. 207-226, 3 pls. (Chinese with English translation).

Zittel, K. A., 1880, Handbuch der Palaeontologie: Munchen and Leipzig, Bryozoa, p. 575-641. 


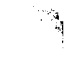




\section{INDEX}

[Italic numbers indicate descriptions]

$A$

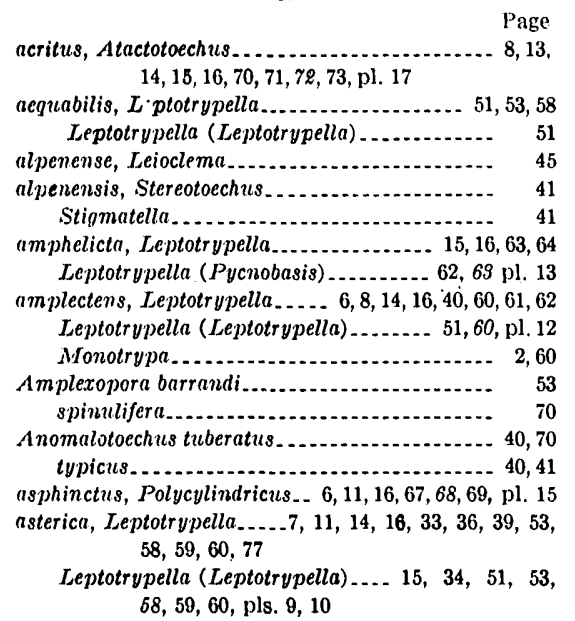

A stogeny, controlling variation of zoaria...... 35, 36

A tactotocchid wall structure................. 32

Atactotoech 6 s.....12, 14, 15, 26, 29, 32, 33, 59, 60, 63, 66, $69,70,71,72,73,76,77,78,79$

acritus..............8, 13, 14, 15, 16, 70, 71, 72, pl. 17

bifoliatus................................. 70

cartus..................... 14, 35, 70, 78, pl. 18 cartus............. $7,16,36,37,70,79$, pl. 18 pilatus................ 7, 16, 70, 73, 74, pl. 18

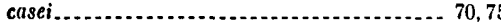

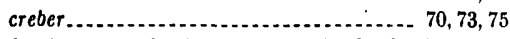

fruticosus....8, 11, 15, 16, 34, 40,59, 60, 70, 71, 72, 76 , pls. 19,20

furcatus.................................... 59 hunanensis . . . hystricosus...............8, 15, 16,70, 71, 72,75, pl.20 inornatus.............................. 70,78

limbatus................................ 70,75

lui......................................... 70

maculosus . $\quad 70$ parallelus.......... $7,9,15,16,70,71,72,74$, pl. 17 reticulatus................................ 70 spinuliferus............................. 70

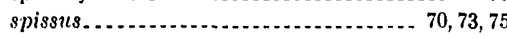
tuberatus................. 70 typicus......................... 69,70,73, 75 verus.................................... 70

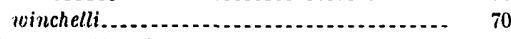
Athyris spiriferoides.......................... 10,61 attenuntum, Lioclema..................... 17, 47,48 Aulocystis tubneformis.........................

Allopora tubaeformis.................... 60

B

Garrandei, Leptotrypella, ................ 53 barrandi, Ampleaopora........................ 53

Chaetetes ............................... 51,53

Leptotrypella. .............................. 51,53

Leptotrypella (Leptotrypella) _........ 51, pl. 8 Monticulipora (Hoterotypta) ............... 53

Bassler, R. S., and Ulrich, B. O., quoted..... 25-26 Batostomella obliqua.......................... 50 tifollatus, Atactotoechus......................... 70 Brachiopods.
Page Bryozoa, growth forms and physical environment.......................... 8 paleoecology

Buffalo axis . . . . . . . . . . . . . . . . . . . . . . . . . 11-12 C

Calacanthopora ......................... 30,48-44 prima............. 43,44 senticosa ................. 6, 16, 17,44, pl. 1 Calcarcous mudstone facies, environment during deposition................ 10-11 Trepostomata in ......................... 10 Callopora punctata.......................... 45 cartus, Atactotoechus............... 14, 35, 70,78, pl. 18 Atactotoechus cartus..... 7, 16, 36, 37, 70,73, pl. 18 pilatus, Atactotoechus........ 7, 16, 70, 73, 74, pl. 18 ctasei, Atactotoechus............................ 70,75 cavernosa, Leptotrypella Centerfield limestone facies.................... 9-10

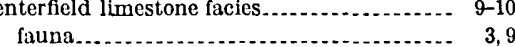
stratigro

aetetes barrandi fruticosus.......................... $58,59,60,76,77$ furcatus............................. 59,60,76,77 clausus Polycylindricus........ 4, 9, 15, 16, 68,69, pl. 16 confertipora, Fistulipora......... 45 Fistuliporina. Thallostigma............................ 45 confertiporum, Leioclema................... 8, 13, 16, $17,33,45,46,47,48, \mathrm{pl} .3$ Lioclema................................. 45
Coquinoid concentrations Corals.......................................... 9-10

Coral-bearing limestone facies, environment and Trepostomata.............. 10 creber, Atactotoechus......................... 70, 73, 75 Cumings, E. R., quoted...................... 26, 33 Cyphotrypa expanda...................... 49 maculosa............................. 70 shearsbyi...

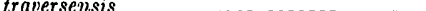

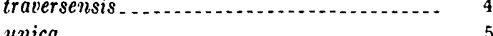

\section{1)}

Dark shale facies, environment and Treposto-

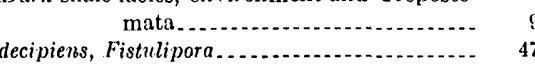
Leioclema.......... 12, 13, 16, 17, 45, 47, 48, pl. Lioclema................................. 47 Thallostigma 47 Deep Run member, fauna and stratigraphy ... 6 Dekayia devonica........................ 2, $67,68,69$ densa, Thallostigma.......................... 45 devonica, Dekayia . . .................. 2,67,68,69 Leptotrypella . . .................... 53, 57, 58 Leptotrypella (Leptotrypella) _............. 51,53 Stenoporella............................... 51 devonicus, Polyclindricus..................... 68 digitata, Thallostigma...................... 45 Discotrypa vera.............................. 70 Duncan, Helen, quoted........................ 10 Dyoidophragma . ..................... 26, 30,34,4t polymorphum ......... $7,12,16,17,42,43, \mathrm{pl} .2$ typicale
F

Page

elasmaticum, Leioclema....... 8, 16,17,45,48,49, pl. Environment, adjustment of zoaria to........ 8 dark shale facies......................... 9-11 Bryozoa as indicators.................... 8

Eostenopora primiformis...................... 49

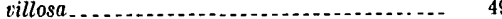

Eridotrypella brevis.................................. 51 spinifera....... $\quad 79$ valida................................... 79 $\mathrm{sp}$ Evolution, trends in Hamilton Trepostomata_ 11, 12 expanda, Cyphotrypa........................ 49 expandus, Trachytoechus....................... $\quad 49$

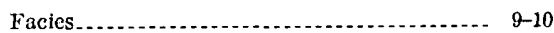

Ficldwork -

Fistulipora confertipora..................... 45

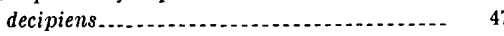
involvens.................................. 45

Fistuliporina confertipora................... 45 fruticosus, Atactotoechus...................... 8 $11,15,16,34,40,59,60,70,71,72,76,77,78$, pls. 19,20

Chaetetes $58,59,60,76,77$

furcata, Leptotrypella........... 8, 11, 15, 16,32, 53, 60 Leptotry pella (Leptotrypella) _.... 51, 53,59, pl. 11

furcatus, Atactotoechus...................... 59 Chaetetes............................ 59,60,76.77

G

Galloway, J. J. and Cumings, E. R., quoted.... 26 gemmata, Leptotrypella Leptotrypella (Leptotrypella)............. 51 Geographic resirictions, Hamilion Trepostomata........................... 13-14

Glossary..................................... 21-23 granulosa, Spinocyrtia ..................... 6,60

H

Tamilton basin, boundary .................. 10-11 Hamilton Trepostomata, compared with Traverse group Trepostomata.... 15

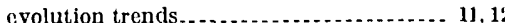
geographic restrictions.................... 13-14 grouping of genera..................... 29-33 growth forms............... 8

lithofacies............................... g marker beds.............................. 11 morphologic distinctions, trends.......... 12,15 phylogenetic relationships................ 12,13 stratigraphic ranges.................... 12 sympatric species........................ 13 taxonomic problems ............... 12, 26-29 taxons, criteria for .................... 12 wall structure............................ 26-29 zoaria (Heterotrypa) barrandi, Monticulipora........ howelli, Trachytoechus..................... 49 hunanensis, Atactotoechus. h.yalinus, Trachytoechus....................... 3 hybrida, Stigmatella. ....................... 78 hystricosus, Atactotoechus. 8, 15, 16.70,71, 72, 75, pl. 20 


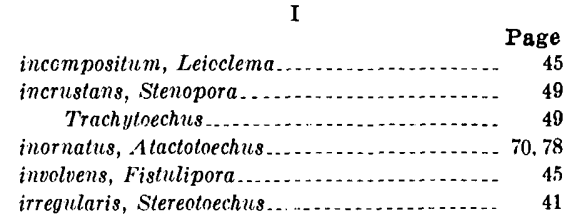

К

Kashong member, stratigraphy, Trepostomata....................... 7,10

King Ferry shale member, siltstone facies.... stratigraphy.......................... 6-7

Trepostomatil.... kwangsiensis, Leptotrypella (Ieptctrypella) . .

\begin{tabular}{c} 
I \\
lechrium, Loxophragma \\
\hdashline$, 8,14,15,16,78,79,80$, pl. 21
\end{tabular}

Ledyard member, dark shale facies ........... stratigraphy, fauna.................. 5

Lee, G. W., quoted......................... 26, 38

Leioclema.................. 26, 30,31,34,44, 45, 47,49

Leioclema alpenense confertiporum .... $8,13,16,17,33,45,46,47,48$, pl. 3 decipiens . . . . . . . . ... 12,13,16,17,45,47,48, pl. 4 elasmaticum.............. 8, 16, 17, 45, 48,49, pl. 4 incc mpositum......................... 45 microporum............................ 45 monroei............................ 2,45,46,47 multaculeatum........................ 45 passitabulatum........................ 45 segregatum........................... 45 traversense............................. 48 Leioclemid wall structure................ . . 30-31 Leiorhynchus fauna . ....................... Leptotrypa nicholsoni....................... 41 spinifera............... 40 Leptrotrypella_. 12, 13, 14, 15, 17, 26, 27, 28, 29, 32, 34, $51,52,53,54,55,59,62,63,71,79$

aequabilis............................ 51, 53,58 amphelicta . . . . . . . . $15,16,63,6$ amplectens ............. 6, 8, 14, 16, 40,60,61, 62 asterica $\ldots . . .7,11,14,16,33,36,39,53,58,59,60,77$ barrandei......................... 53 barrandi................. 51,58 cavernosa. . . . devonica........................... 53,57,58 furcata.................... 8, $811,15,16,32,53,60$ gemmata. magninedcsa........... 53,58 magniporta.................... 12, 14, 16,62 mesostena $15,52,53,54,55,56,59,64$ mesostema... _. 4, 46, 30, 40, 52, 53. 55, 56, 63, 64 provecta................. 14, 16,52,53,55,50 monilifcrmis .......................... 53 mulitecta_. $6,7,8,14,15,16,33,39,40,52,53,54$, $55,56,57,59,63,64$

ohioensis........................... $51,52.53$ pachyphragma........................ 16,63 pellucida............................. 53 polita............................... $7,16,63,66$ solitaria.................................. 51 tuberata.................... 6, 7, 16,33,63,66 undans.............................. 51 naria $\ldots$

Leptotrypella (Leptotrypella) . . . . . . . 13, 51,60,63 (Leptotrypella) aequabilis................. 51 amplectens asterica....... 15, 34, 51, 53, 58, 59,60, pls. 9,10 asterica $\ldots \ldots \ldots 15,34,51,53,58,59,60$, pls. 9,10
harrandi.............

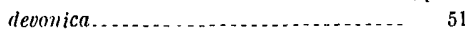
furcata..................... 51.53,59, pl. 11 yemmata............................ 51 hwangsiensis...................... 51 magninodosa........................ 51 magniporta mesostena....................... 52,54,55 mesostena................. 52,55. pl. 6 privecta. . . . . . . . . . 52,56, pl. 6
Leptotrypella (Leptotrypella)-Continued moniliformis ......... 52 multitecta $\ldots \ldots \ldots$. ohicensis.......................... 52 parva............................. 52 pellucida....................... 52 unica...

Leptotrypella (Pycnobasis) _.

(Pycnobasis) amphelicta............ 62,63, pl. 13 pachyphragma................ 64, pl. 15 polita........................... 66, pls. 13, 14 tuberata....................... $65, \mathrm{pl} 14$ Leptotrypellid wall structure................ 32 leptum, Loxophragama .... 4, 14, 15, 16, 79, 81, pl. 21

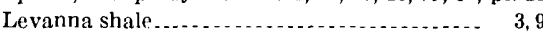
limbatus, Atactotoechus...................... 70,75

Lioclema attenuatum.................... 17,47,48 confertiporum ........................ 45 decipiens............................... 47 monroei........... 45 traversense....................... 45,47,48 Lithologic units, Hamilton groups ........... 11 Localities, description. . . . . . . . Loxophragma . . . . . . . . . 12, 15, 33, 63, 66, 71, 78, 79, 80 lechrium ............ 6, 7,8 $14,15,16,78,79,80$, pls. 21,22 leptum_............ $4,14,15,16,79,81$, pl. 21 spiniferum........... 81 validum

varium........... 80

Lurllowville shale, Centerfield limestone member........................

Deep Run member.

king Ferry shale member. . . . . . . . . . . .

Led yard member.................

lithofacies............................. 9-11

stratigraphy ....................... $3-7$

Tichenor limestone member ............. 6

Trepostomata.

Wanakah shale member........... 4-5

lui, Atactotoechus.......................... 70

\section{$M$}

maculosa, Cyphotrypa maculosus, Atactotoechus magninodosa, Leptotrypella ................... 53,58 Leptotrypella (Leptotrypella) _..._. magniporta, Leptctrypella. .............. 12. 14, 16,62

Leptotrypella (Leptotrypella) _....... 51, 61, pl. 12 Marcellus fauna. See Leiorhynchus fauna.

Marcellus shale......................... 39

Marker beds, Hamilton group................ 11 marylandensis, Monticulipora $\quad 40,51,60,61$ mesostena, Leptotrypella _... 15, 52,53,54,55, 56, 59, 64

Leptotrypella mesostena_._. 4, 16, 30, 40,52, 53, $55,56,63,64, \mathrm{pl} .6$ mesostena, Leptrotrypella (Leptrotrypella) _ 52, 56, provecta, Leptotry pella_._. 14, 16, 52, 53, 55,56 , pl. 6 moniliformis, Leptotrypella.

Leptotrypella (Leptotrypella) Trachytoechus...........................

Monotrypa amplectens monroei, Leioclema........................ 2, 45, 46.47 Lioclema

Monticulipora (Heterotrypa) barrandi_........ 53 marylandensis . . . . . . . . . . . . . . . 40,51,60,61 monticula............................... 4 monticula, Monticulipora.

monticulatus, Trachytoechus................. monticulus, Stereotoechus...

Morphologic trends of IIamilton Trepostomata......... 15

Morphology of 'Trepostomata................ 23-40

Moscow siale, kas':ong member.......... 7 Portland Point member............... 7 stratigrap'ay ............................. $7-8$
Moscow shale-Continued

Trepostomata.

vindom member multaculeatum, Leioclema.................... 45 multitecta, Leptotrypella .... 6, 7, 8, 14, 15, 16, 33, 39, $40,52,53,54,55,56,57,59,63,64$ Leptotrypella (Leptotrypella)...... 34, 52,57,64, pls. 7,8

nicholsoni, Leptotrypa..... 0

obliqua, Rastostomella....................... ohioensis, Leptotrypella Ontogenetic characters. . . . . . . . . . . . . . 36, 38 Orbignyella tenera

$\mathrm{P}$

pachyphragma, Leptotrypella Leptotrypella (Pycnobasis) ........... 64, pl. 15 Pryozoa...................... 8-11 Paleogeograp.yy, Hamilton group ............ 11-12 Paleschara reticulata

variacella. parallelus, Atactotoechus . $7,9,15,16,70,71,72,74$ pl. 17 parva, Leptctrypella (Leptotrypella) .......... 52 passitabulatum, Leinclema................... Pelecypods.................................. pellucida, Leptotrypella

Leptotrypella (Leptotrypella) Phylogenetic relations.hips, Hamilton Trepostomata. . . ................... 12,13

pilatus, Atactotoechus cartus.... 7, 16, 70, 73, 74, pl. 18 Pleurodictyum zone............... 4, 6, 10, 18, 19, 20,61 polita, Leptotrypella .................. 7, 16,63,66 Leptotrypella (Pycnobasis) _.......... 66, pls.13, 14

Polycylindricus _........ 4,32,40,67 osphinctus............ 6, 11, 16, 67,68,69, pl. 15

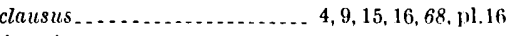
devonicus.

polymorphum, Dyoidophragma............. 7 , $12,16,12,42,43, \mathrm{pl} .2$ Portland Point member, stratigraphy, fauna _. 7 Previous work............................ 2 prima, Calacanthopora....................... 43,44 primiformis, Eostenopora pronecta, Leptotrypella (Leptotrypella) mesostena............ 52,56, pl. 6 Leptotrypella mesostena....... 14, 16, 52,53, 55, 56 punctata, Callopora (Pycnobasis) amphelicta, Leptotrypella _. 62,69, pl. 13 Lept strypella. . . . . . . . . . . $13,15,51,62$ pachyphrayma, Leptotrypella......... $64, \mathrm{pl} .15$ polita, Leptotrypella ................. 66, pls. 13, 14 tuberata, Leptotrypella. . . . . . . . . . . 6.... pl. 14

IR

reticulata, Paleschara.................... reticulatus, Atactotoechus..................... 7 romingeri, Trachytoechus. ...............

$\mathrm{S}$

Sandstone facies, deposition, fauna........... segregatum, Leioclema....................... 45 senticosa, Calacanthopora........... 6, 16, 17,44, pl. 1 shearsbyi, Cyphotrypa......................

Stereotoechus.

Siltstone facies, deposition, fauna............. Skaneateles formation, stratigraphy, fauna.... 3,9 solitaria, Leptotrypella..................... spinifera, Eridotrypella..................... 79 Leptotrypa spiniferum, Loxophragma................... 81 spiniferus, Stereotoechus..................... 40.4 Spinocyrtia granulosa...................... 6,60 spinulifera, Amplex)pora................. 7 spinuliferus, Atactotoechus.................. 70 spiriferoides, Athyris.......................... 10,61 
Page

spissus, Atactotoechus....................... 70,73,75

Stach, L. W., quoted......................... 8

Stafford limestone, stratigraphy, fauna........ 3

Stenopora incrustans ........................... $\quad 49$

Stenoporella devonica....................... 51

Stereotoechid wall structure.................. 30

Stereotoechus $\quad 26,31,40,41$

alpenensis.............................. 41

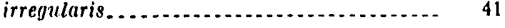

monticulus

shearsbyi.............................. 41

spiniferus................................ 40,41

traversensis

tenerus............................ 41

typicus....................... 4, 16, 40,41, pl. 1

stigmatella alpensis_....................... 41

hybrida................................ $\quad 78$

Strutigraphy................................ 3-8

Stratigraphic ranges of Hamilton Trepostomata............................ 12

Strophalosia beds....................... 4, 10,11

subtilis, Thallostigma......................... 45

Sympatric species in Hamilton Trepostomata. $\quad 13$

Systemutic descriptions................... 40-81

Taxonomy of Trepostomata. $12,23-33$

tenera, Orbignyella..

Thallostigma confertipora

decipiens.

densa.

digitata

45

Tlet:enor limestone member................. 6, 9-10 ionships in Hamilton Trepostomata.

13

Trachytoechid wall structure of Trepostomata

13

31

'xpandus................................... 49

moniliformis

monticulatus

romingeri.

typicus

variacellus. ............ 4,9,11,15,16,17,49, pl. 5

Traverse Trepostomata, Hamilton Trepostomata comparison................ 15

tentative grouping of genera

traversense, Leioclema...................... 48

Lioclema.......................... 45,47,48

traversensis, Cyphotrypa................... 40

Stereotocchus............................ 41

Trepostomata, morphology ................. 23-40

Trilobite zones............................ 10

tubaeformis, Aulocystis.................. 6

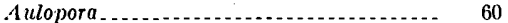

tuberata, Leptotrypella ......... 6, 7, 16, 33,63,66

Leptotrypella (Pycnobasis) .............. 65, pl. 14

tuberatus, Anomalotoechus.................... 40,70

Atactotoechus........................... 70

typicale, Dyoidophragma..................... 41

typicus, Anomalotoechus......................... 40,41 Atactotoechus. . . .................... 69, 70, 73,75 Stereotoechus. . ............... 4, 16, 40,41, pl. 1

Trachytoechus.......................... 49

$\mathrm{U}$

Uilrich, E. O., and Bassier, R. S., quoted.... 25-26 undans, Leptotrypella.
Page

unica, Cyphotrypa Leptotrypella (Leptotrypella)

valida, Eridotrypella validum, Loxophragma . ....................... 81 varia, Leptotrypella......................... 79 variacella, Paleschara....................... 49 variacellus, Trachytoech $u s \ldots . .4,9,11,15,16,17,49, \mathrm{pl} .5$ $\begin{array}{ll}\text { varium, Loxophragma } & \\ \text { vera, Discotrypa } & \end{array}$

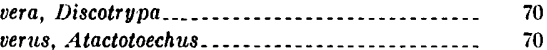

villosa, Eostenopora....................... 49

winchelli, Atactotoechus..................... 70 Wall structure of Trepostomata, classification by

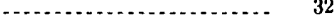

leioclemid .......................... 30

leptotrypellid. ........... 32

previous work ........................... 25-26

stereotoechid........................ $\quad 30$

taxonomic problems.................... 26-29

trachy toechid. . . . 31

Wanakah shale...................... 4-5, 6, 10

Windom member.

Zoaria, adjustment to environment.......... 8 morphology in taxonomy ramose growth of ....................... 38 variation of, as species eriteria . . . . . . . . 35-38 controlled by astogeny............... 35 
PLATES 1- 22 


\section{PLATE 1}

Figure 1. Stereotoechus cf. S. typicus Duncan (p. 41).

1a. Longitudinal section of specimen, USNM $133853, \times 50$, containing spherical cysts attached to thin diaphragms. Centerfield limestone member of Ludlowville shale, collection 275A.

1b. Longitudinal section of same specimen, $\times 75$, showing stereotoechid wall structure.

1c. Tangential section of same specimen, $\times 50$, showing amalgamate appearance and megazooecia in bottom half of figure.

2-4. Calacanthopora? senticosa Boardman, n. sp. (p. 44).

2a. Tangential section of holotype, USNM $133854, \times 50$, showing amalgamate walls, numerous large acanthopores, and a few mesopores. Wanakah shale member as used by Buehler and Tesmer (in press) of Ludlowville shale collection 3502.

2b. Longitudinal section of holotype, $\times 50$, a ramose specimen, the branch containing a hollow axial tube.

3. Tangential section of paratype, USNM $133855, \times 50$, showing mesopores. Wanakah shale member, collection 3502 .

4. Longitudinal section of paratype, USNM $133856, \times 50$, a young zoarium incrusting a crinoid stem. Note the configuration of the basal lamina caused by the annulated ridges of the crinoid columnals and the general similarity to the configuration of the basal lamina of the holotype specimen, fig. 2b. Wanakah shale member, collection 3502 .

5. Eridotrypella sp. (p. 50)

5a. Tangential section of specimen, USNM $133857, \times 50$, showing large mural lacunae filled with opaque material to produce coarsely granular appearance. Windom member of Moscow shale, collection 3553.

$5 \mathrm{~b}$. Longitudinal section of same specimen, $\times 50$, showing small zooecial angle and wall structure characteristic of genus. 
GEOLOGICAL SURVEY

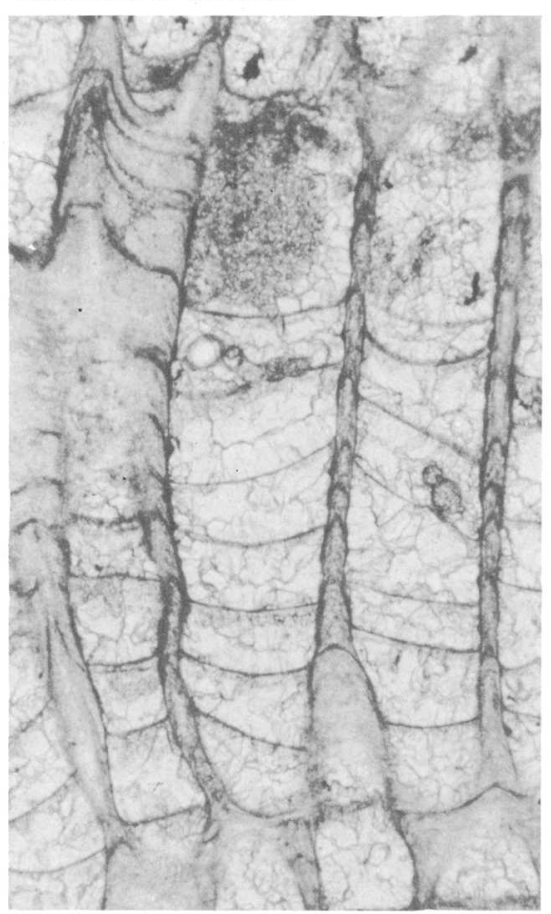

1 a

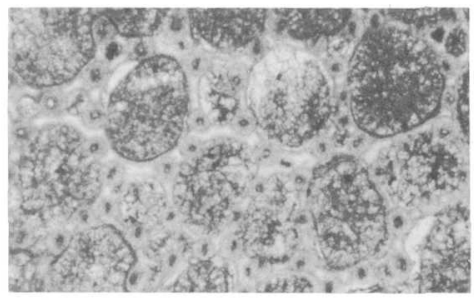

$2 a$

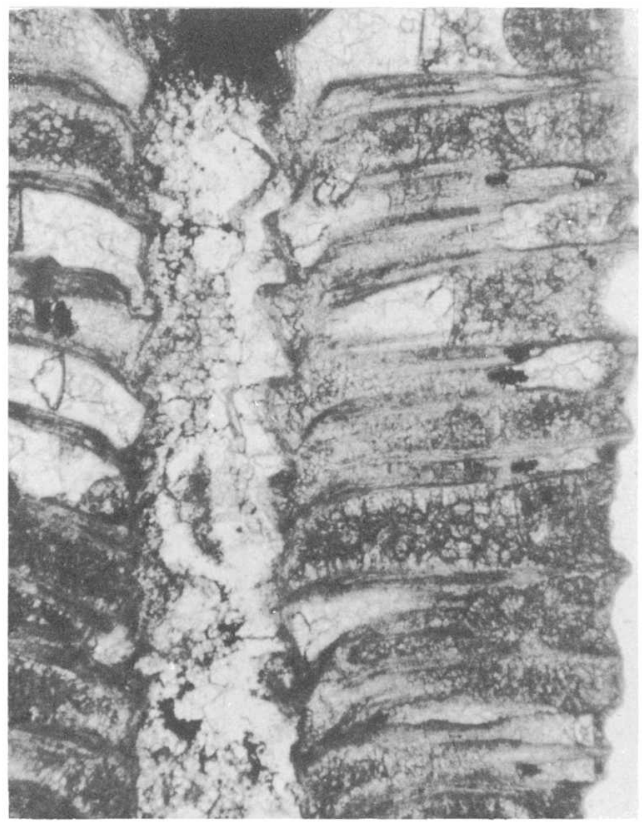

$2 b$

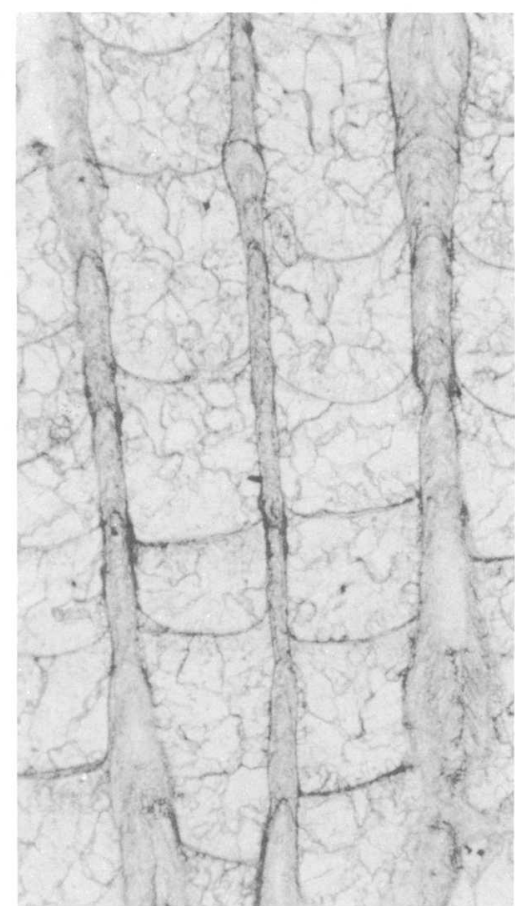

$1 \mathrm{~b}$

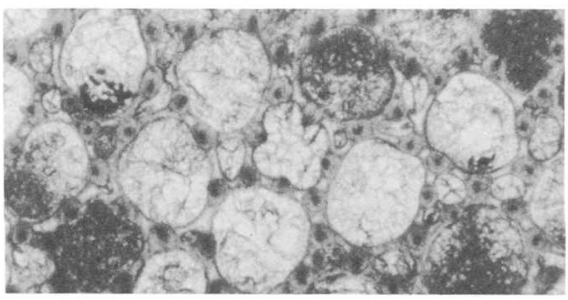

3

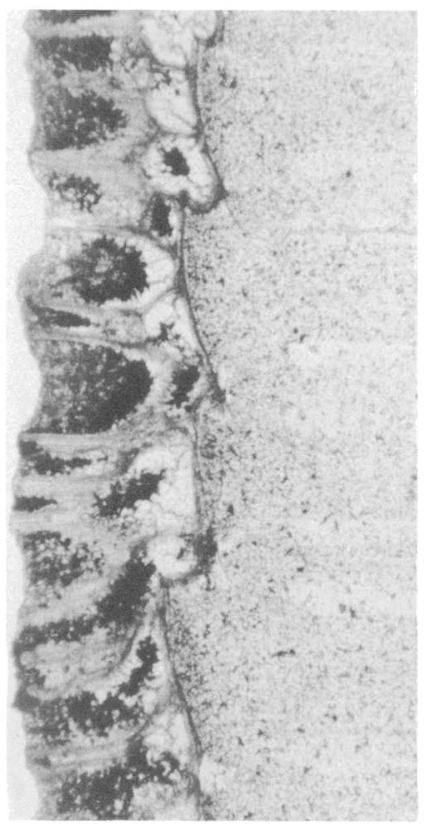

4
PROFESSIONAL PAPER 340 PLATE 1
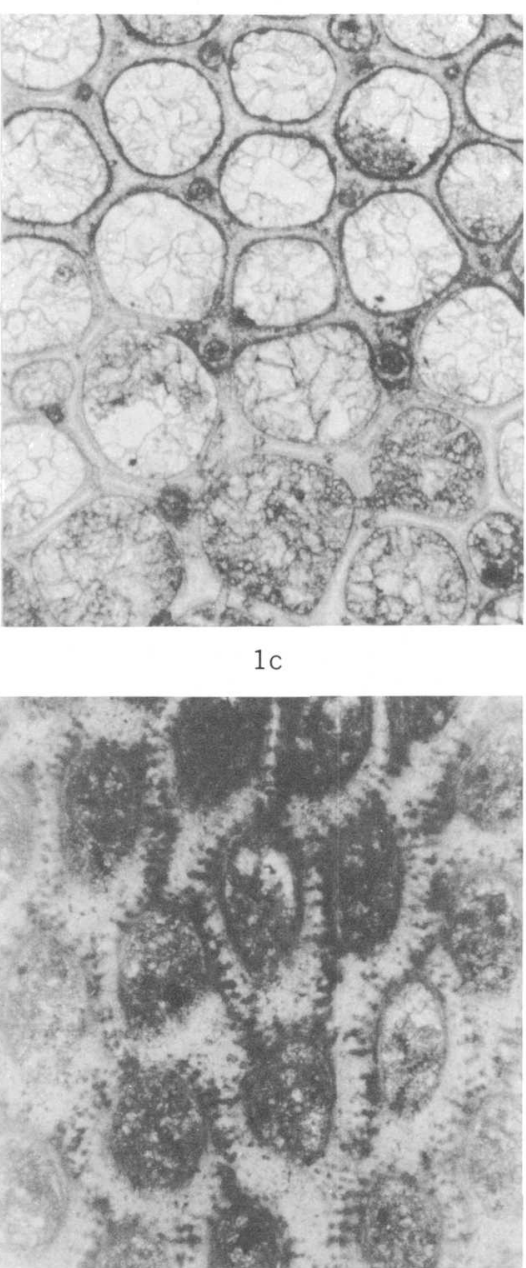

$5 a$

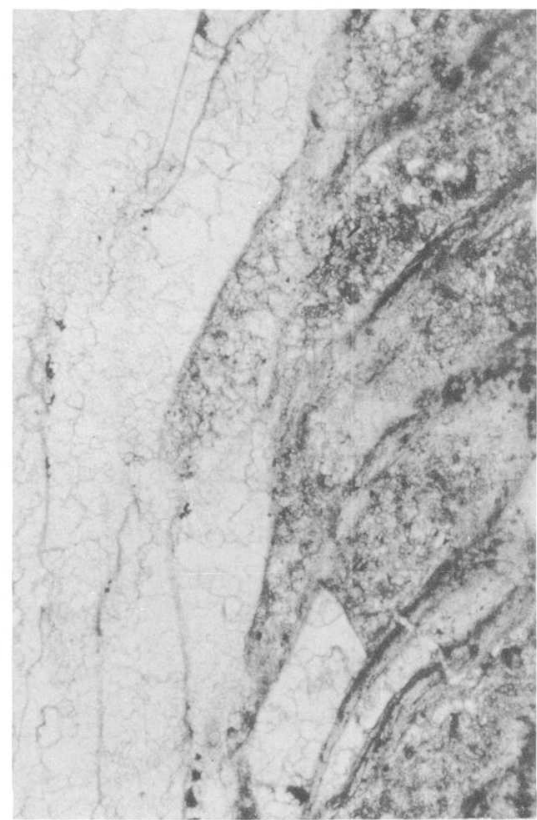

$5 b$

STEREOTOECHUS CF. S. TYPICUS, CALACANTHOPORA?, AND ERIDOTRYPELLA 
GEOLOGICAL SURVEY
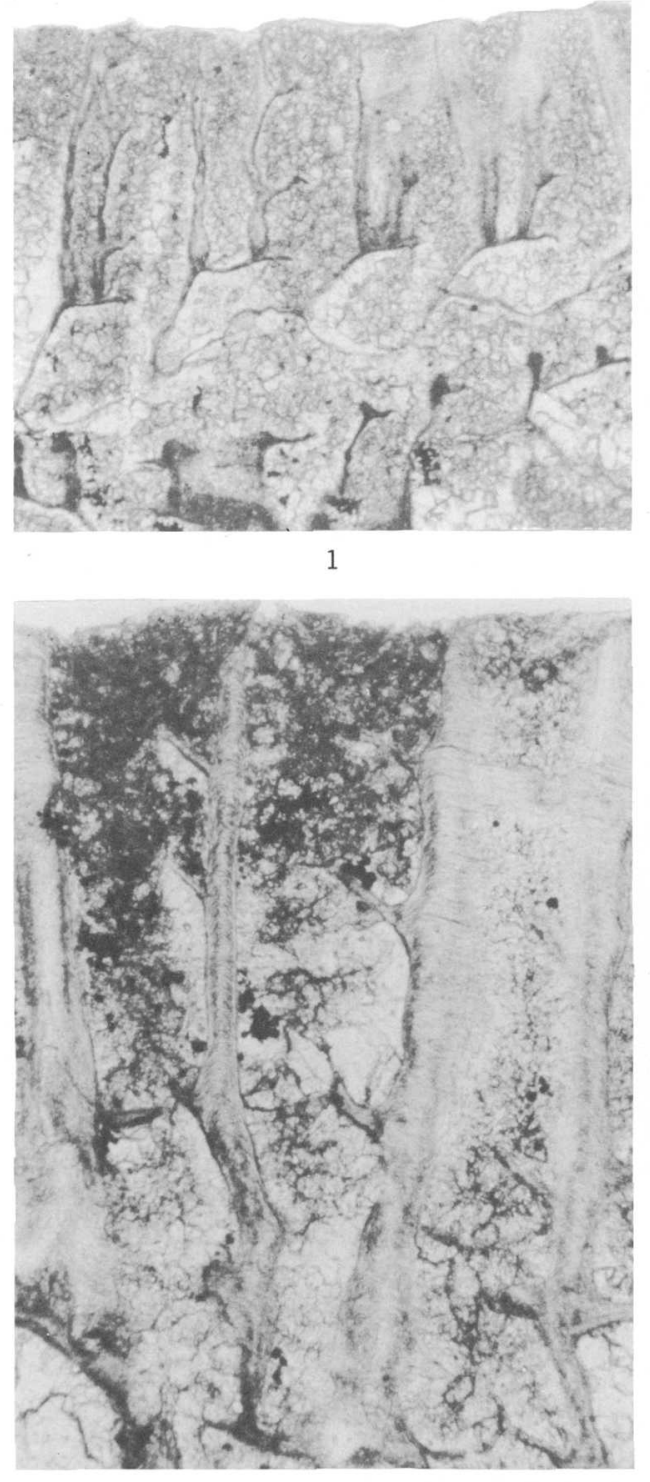

4

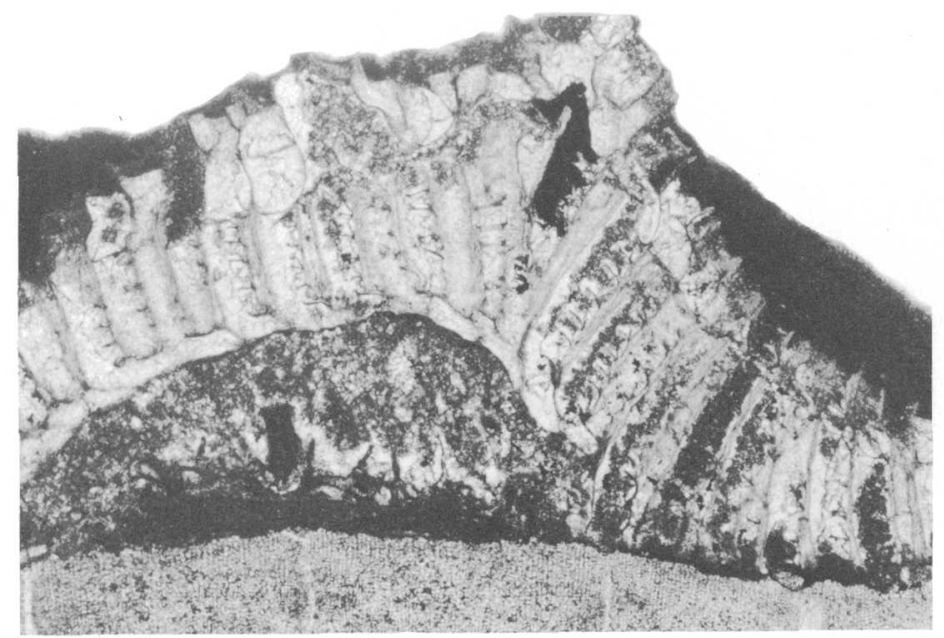

6

5

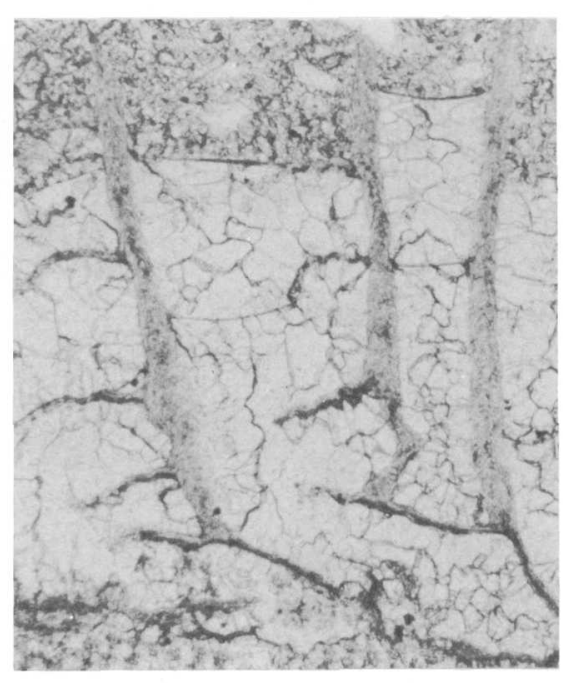

2
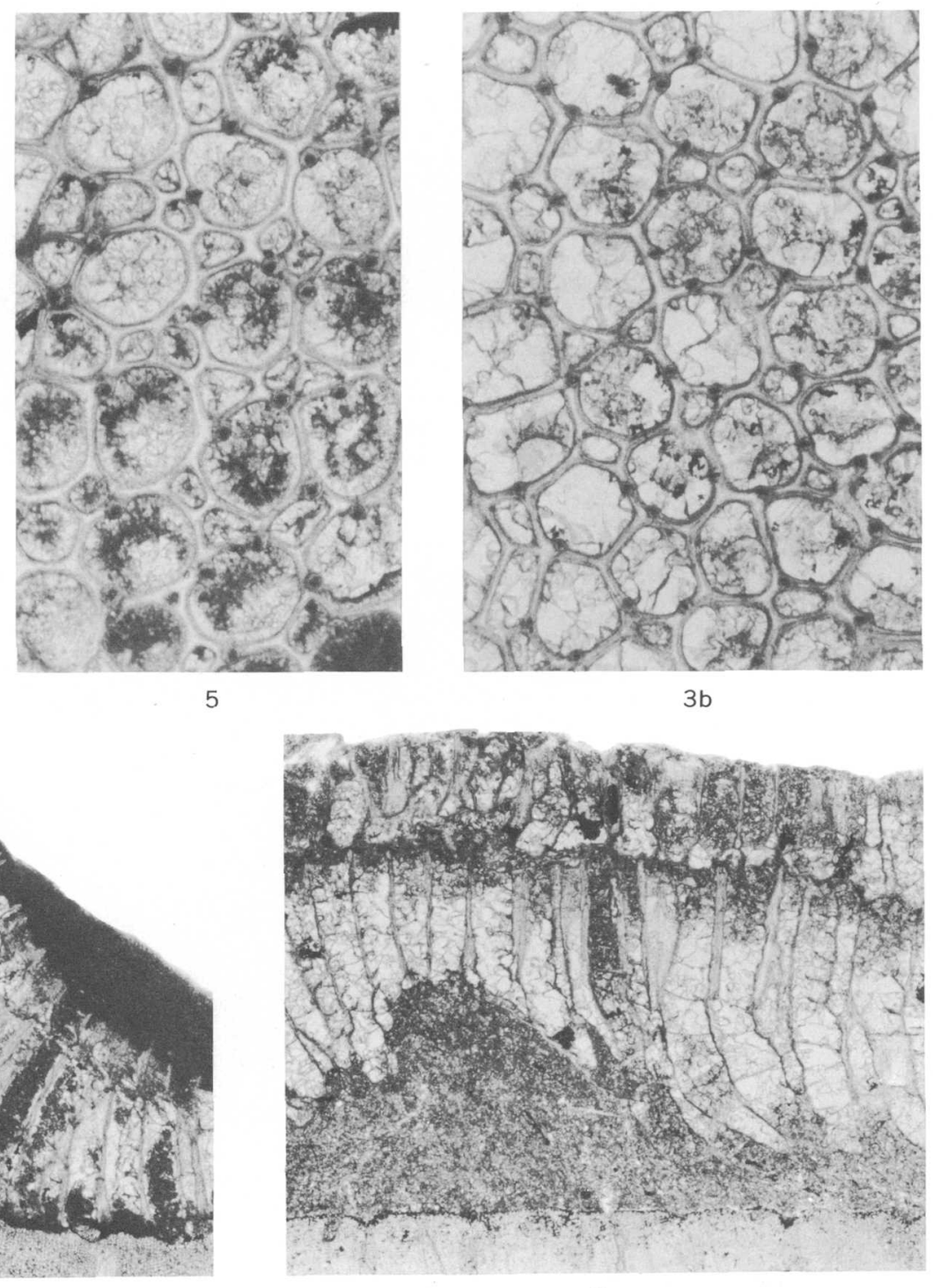

$3 c$

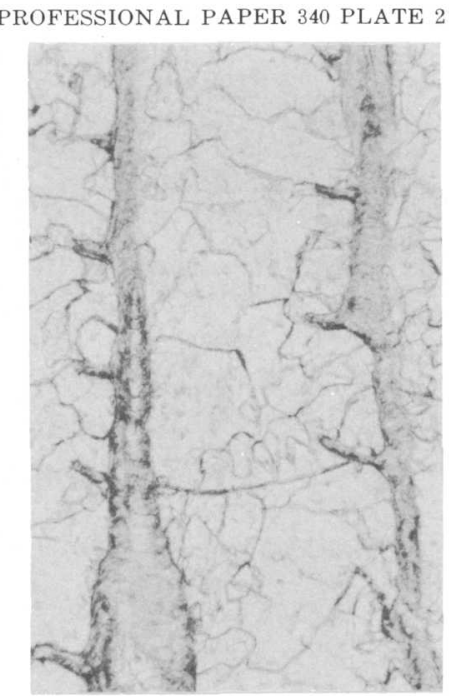

$3 a$

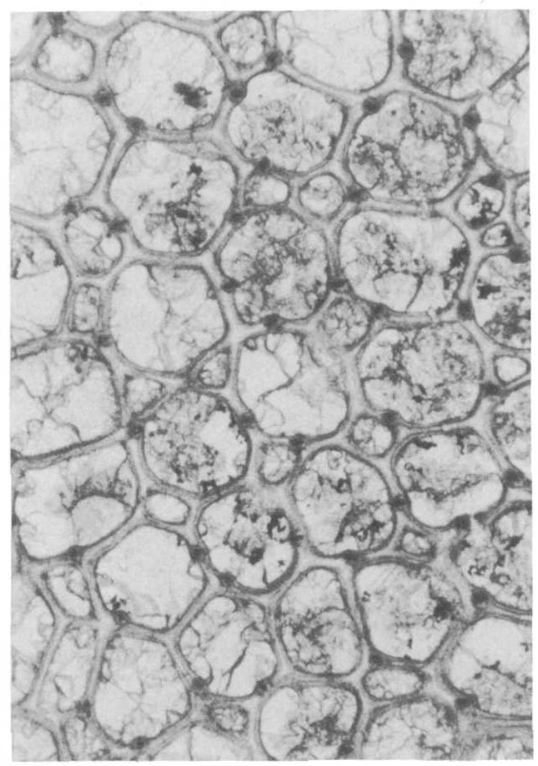

$3 \mathrm{~b}$

DYOIDOPHRAGMA POLYMORPHUM, N. SP. 


\section{PLATE 2}

Ficures 1-6. Dyoidophragma polymorphum Boardman, n. sp. (p. 42).

1. Longitudinal section of paratype, USNM $133859, \times 50$, displaying a zooecial wall inflection at point of attachment of hemiphragm. Wanakah shale member (as used by Buehler and Tesmer, in press) of Ludlowville shale, collection 1015 .

2. Longitudinal section of paratype, USNM $133860, \times 100$, showing abnormally crenulated hemiphragms. Kashong member (of Cooper, 1930) of Moscow shale, collection 3500.

3a. Longitudinal section of holotype, USNM $133861, \times 100$, displaying stereotoechid wall structure and the laminated nature of the hemiphragms. King Ferry shale member (of Cooper, 1930) of Ludlowville shale, collection 3564 .

3b. Tangential section of holotype, $\times 50$, showing amalgamate zooecial walls and mesopores.

3c. Longitudinal view of holotype, $\times 20$, showing incrusting relationship of zoarium to crinoid stem with intervening layer of mud, abnormally long neanic zone, and conspecific overgrowth.

4. Longitudinal view of paratype, USNM $133862, \times 100$, showing unusually well preserved wall structure and laminated hemiphragms. Wanakah shale member, collection 3558a.

5. Tangential section of paratype, USNM 133863, $\times 50$, showing amalgamate structure and numerous mesopores. Kashong member, collection 3552.

6. Longitudinal view of paratype, USNM 133864, $\times 20$, showing the basal lamina in direct contact with the crinoid stem and an intervening pocket of mud. Kashong member, collection 3500 . 


\section{PLATE 3}

Firiures 1-3. Leioclema confertiporum (Hall) (p. 45).

1a. Longitudinal view of incrusting specimen, USNM 133865, $\times 20$, showing strong wall thickening of monticular zooecia. Wanakah shale member (as used by Buehler and Tesmer, in press) of Ludlowville shale, collection 3558 .

1b. Longitudinal view of same specimen, $\times 20$, displaying fistuliporoid-like vesicular structure in the neanic zone.

$1 \mathrm{c}$. Tangential section of same specimen, $\times 50$, showing thickened zooecial walls in monticule and large central canals in some of the acanthopores.

2a. Longitudinal view of identified specimen, USNM 133866, $\times 10$, illustrating morphologic similarity between conspecific overgrowth of subramose form and incrusting zoaria. Note the similar vesicular development in the neanic region of fig. 1 b. Centerfield limestone member of Ludlowville shale, collection 3528 .

$2 \mathrm{~b}$. External view of part of the zoarium of the same specimen, $\times 1$, showing the subramose growth habit.

2c. Longitudinal view of the same specimen, $\times 5$, illustrating the formation of a short branch by a series of overgrowths.

3a. Longitudinal view of lectotype, New York State Museum $734, \times 50$, showing the leioclemid wall structure, some vesicular tissue in the neanic zone, and the large central canals of the acanthopores. Hamilton group, Moscow, N.Y.

3 b. Tangential view of lectotype, $\times 50$, showing amalgamate wall structure, numerous mesopores, and strong zooecial wall thickening in lower right corner of figure. 

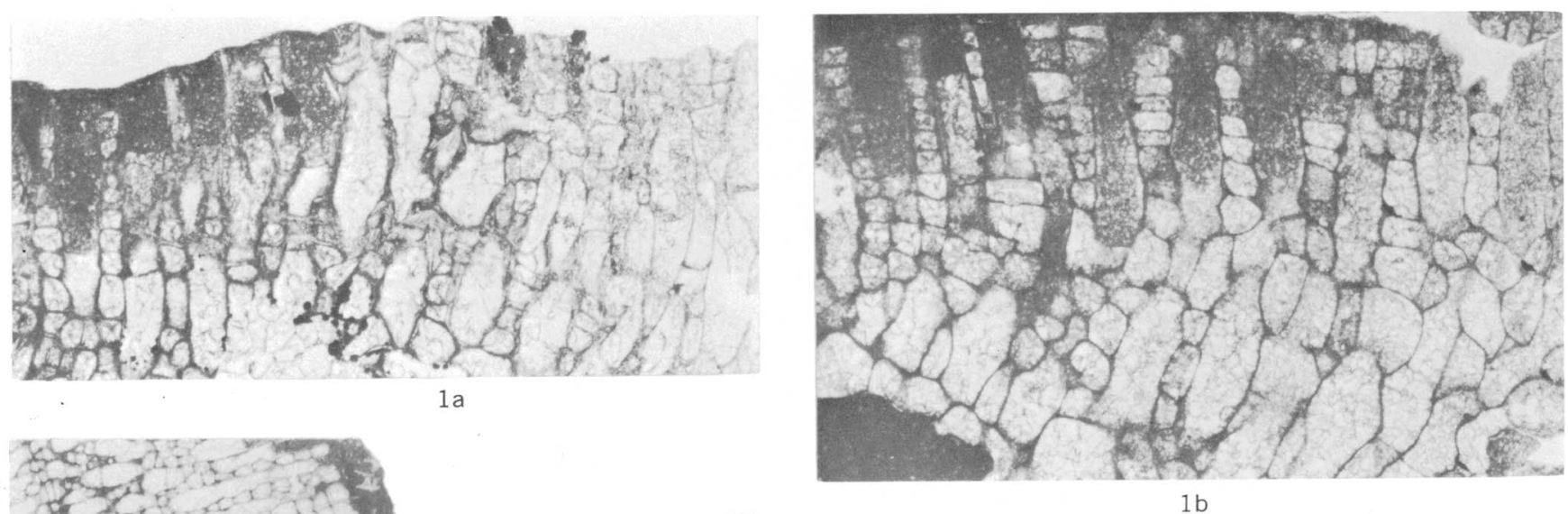

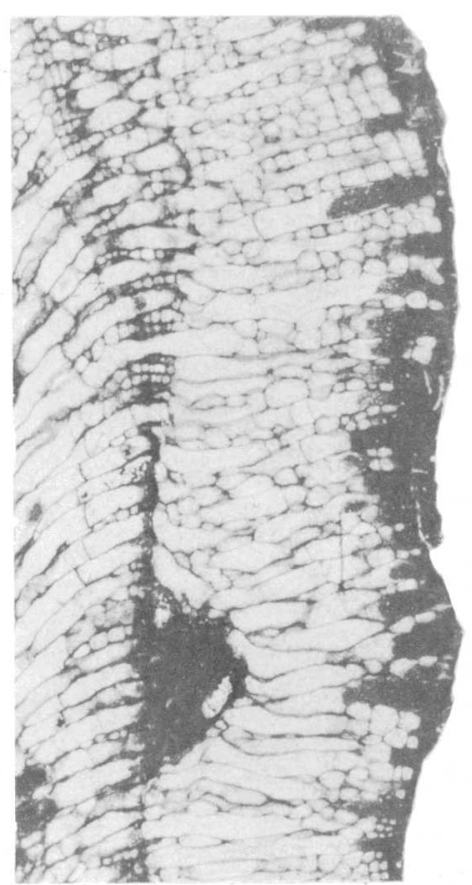

$2 a$

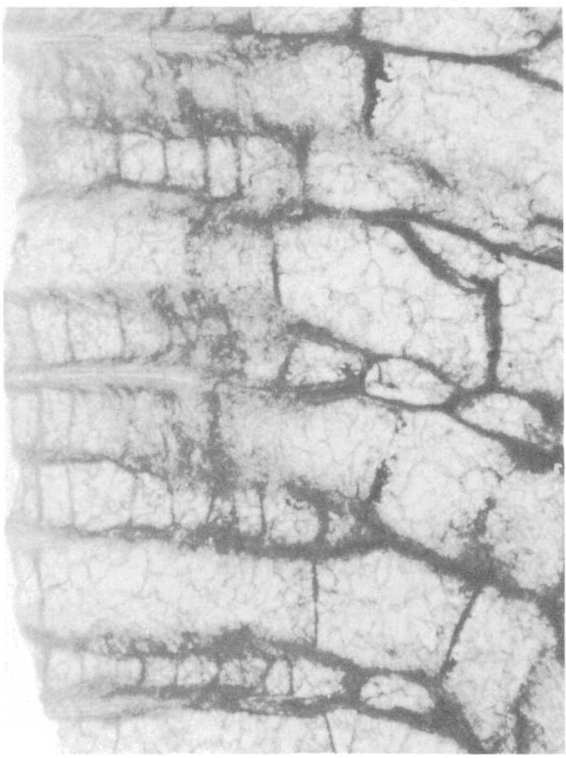

$3 a$
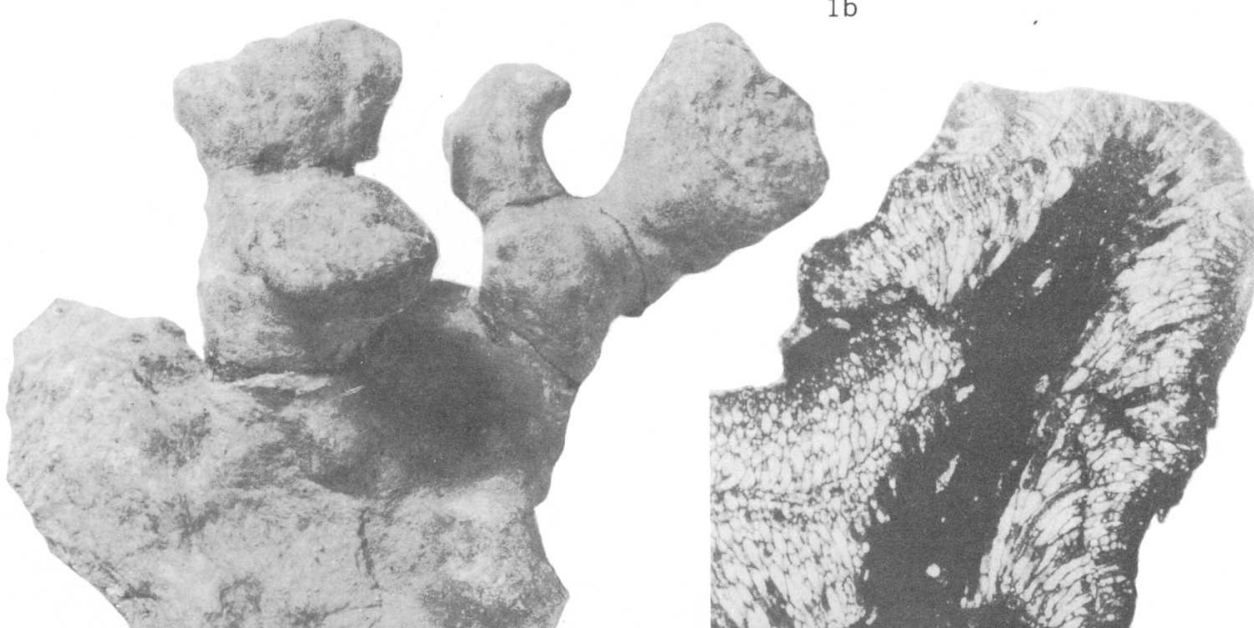

a ${ }^{2}$

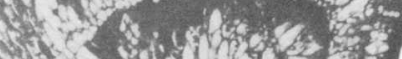

N.t.

$2 b$

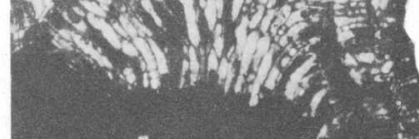

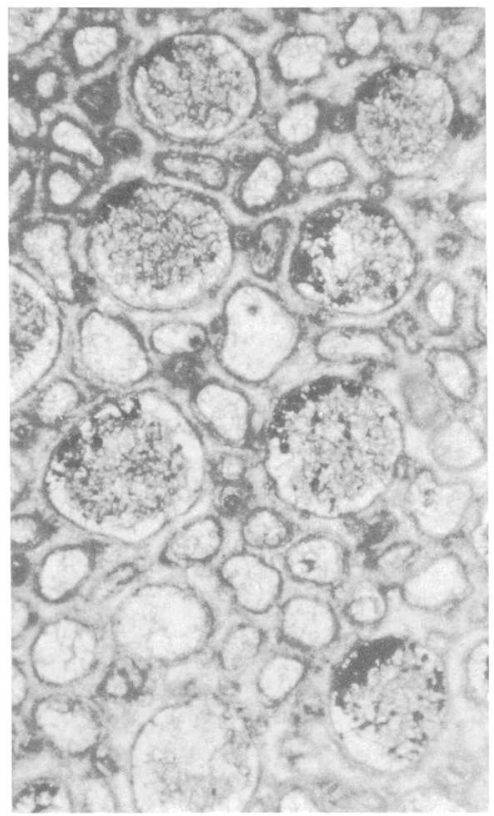

$3 b$
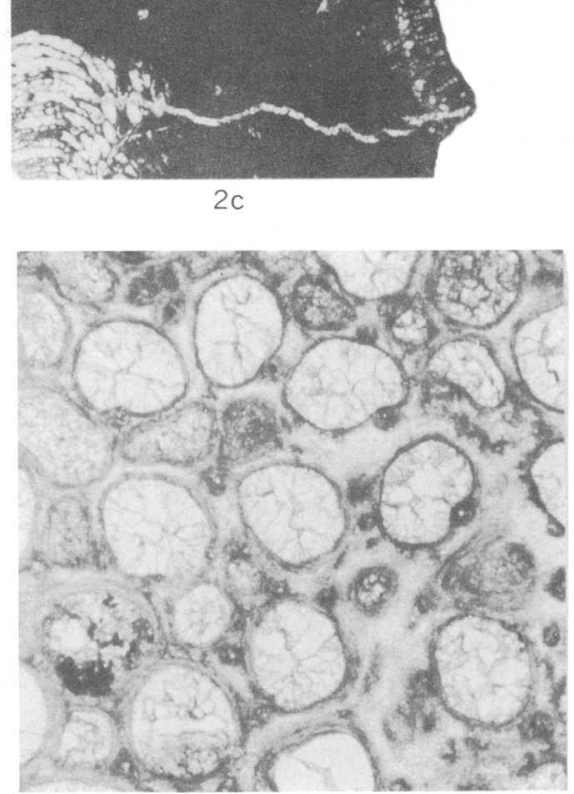

$1 \mathrm{c}$ 


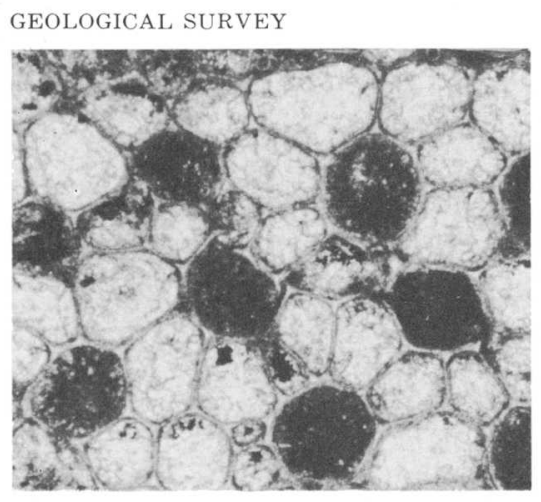

$1 \mathrm{a}$
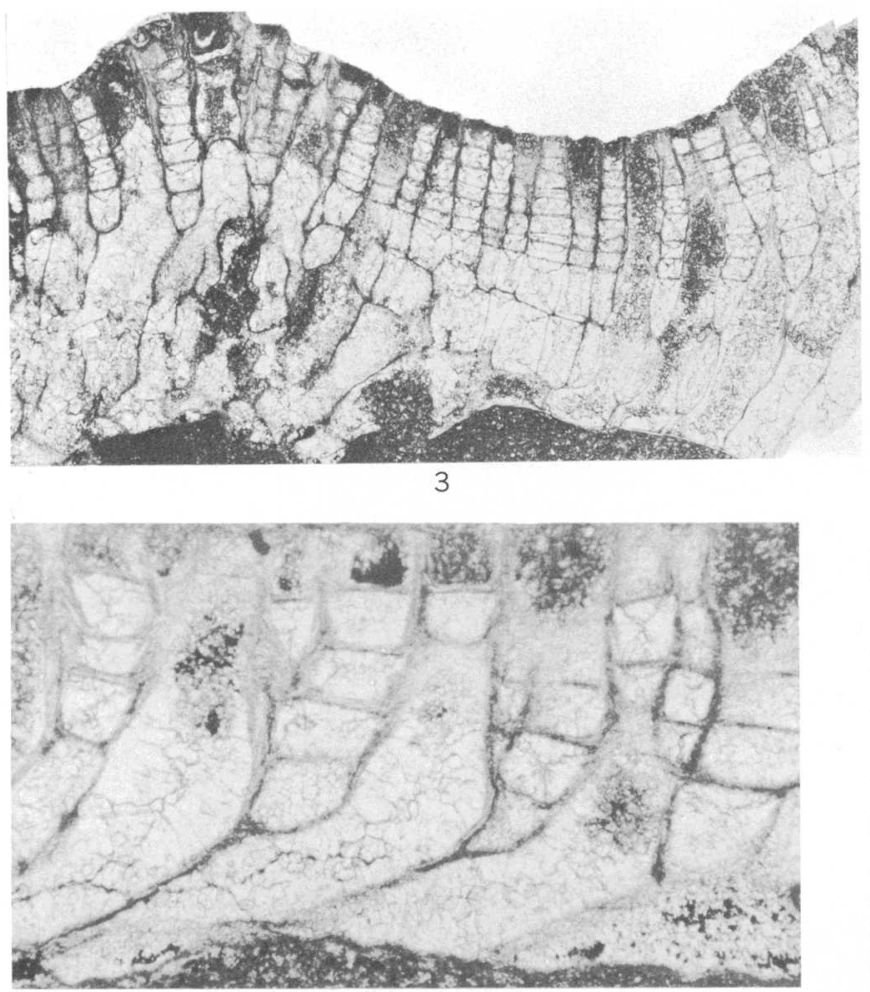

$5 a$

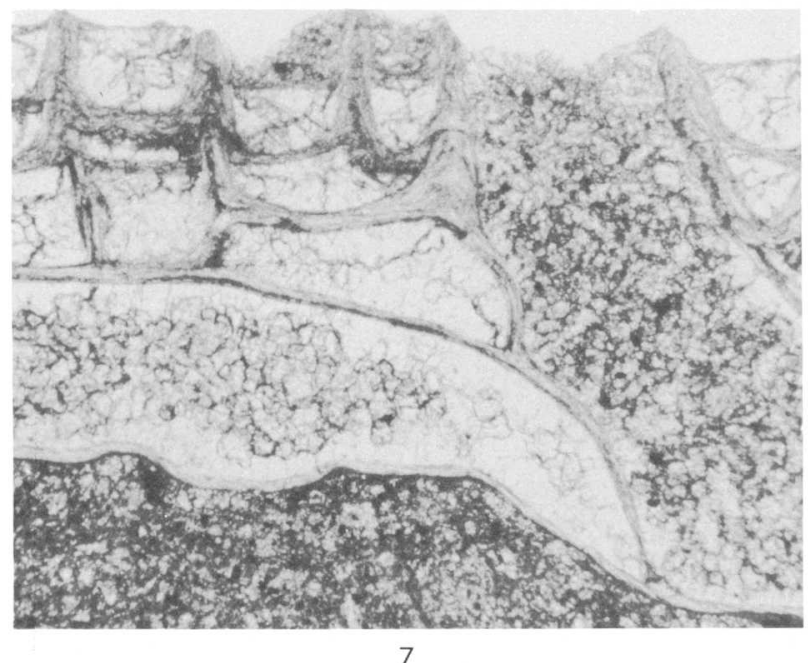

PROFESSIONAL PAPER 340 PLATE 4

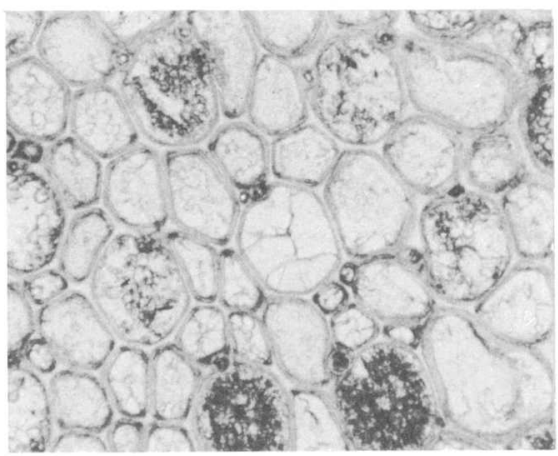

2

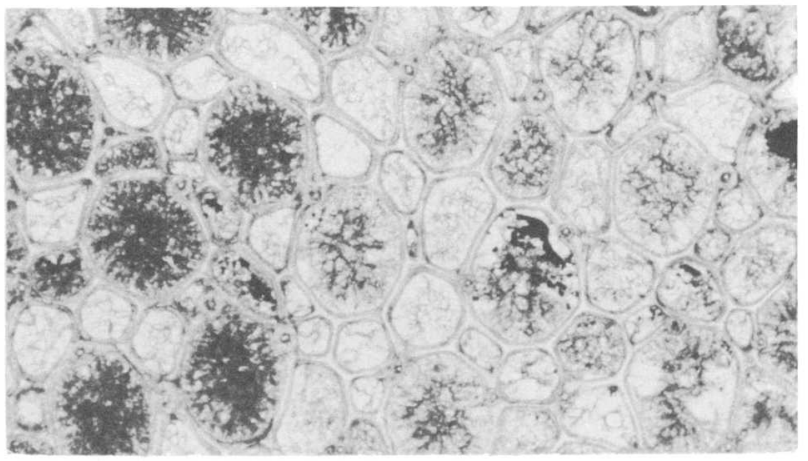

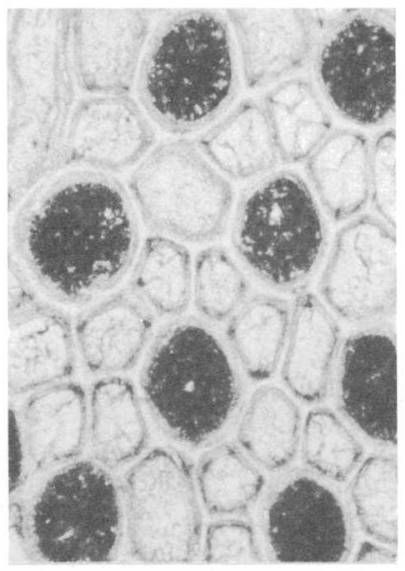

$5 b$

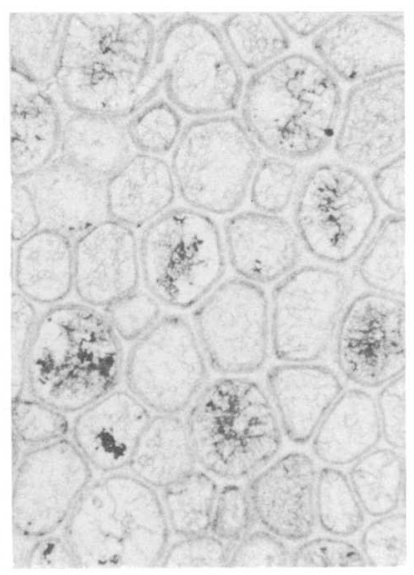

6

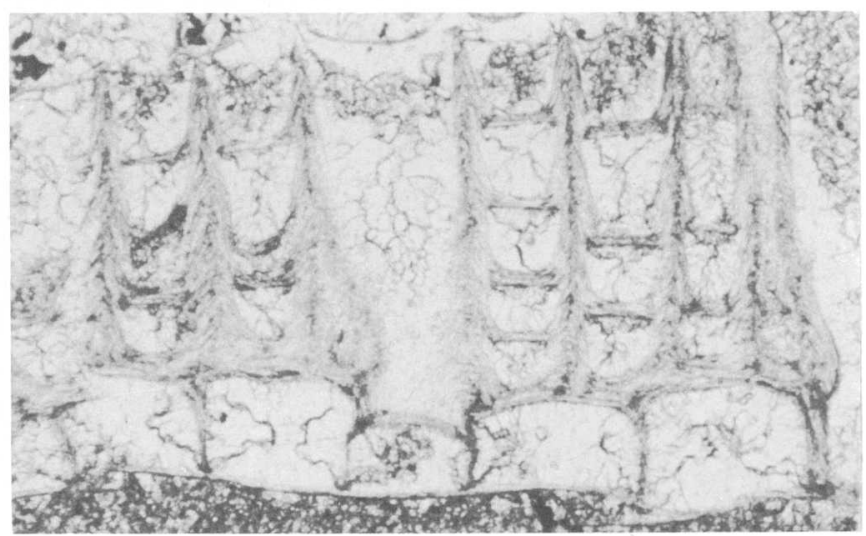

8

LEIOCLEMA DECIPIENS AND LEIOCLEMA ELASMATICUM, N. SP. 


\section{PLATE 4}

Figures 1-4. Leioclema decipiens (Hall) (p. 47).

1a. Tangential section of holotype, New York State Museum $737, \times 50$, displaying thin zooecial walls and a few large acanthopores. Hamilton group, York, N.Y.

1b. Longitudinal view of holotype, $\times 50$, revealing a young zoarium covered with a conspecific overgrowth. Note large central canals of acanthopores in both primary zoarium and overgrowth.

2. Tangential section of identified specimen, USNM $133867, \times 50$, showing amalgamate wall structure, large acanthopores containing large central canals and numerous mesopores. King Ferry shale member (of Cooper, 1930) of Ludlowville shale, collection 3582.

3. Longitudinal view of a well developed zoarium, USNM $133868, \times 20$, showing subrectangular compartments in the mesopores in the neanic zone. Wanakah shale member (as used by Buehler and Tesmer, in press) of Ludlowville shale, collection 3558a.

4. Tangential section of identified specimen, USNM $133869, \times 50$, showing very large acanthopores. Kashong member (of Cooper, 1930) of Moscow shale, collection 3552.

5-8. Leioclema elasmaticum Boardman, n. sp. (p. 48).

5a. Longitudinal section of holotype, USNM $133870, \times 50$, Windom member of Moscow shale, collection 3559.

$5 \mathrm{~b}$. Tangential section of holotype, $\times 50$, displaying amalgamate walls, mud filled subcircular zooecia, subpolygonal mesopores, and no acanthopores.

6. Tangential section of paratype, USNM $133871, \times 50$, showing zooecia and mesopores and no acanthopores. Windom member, collection 3559 .

7. Longitudinal section of paratype, USNM $133872, \times 100$, displaying the laminated nature of the basal lamina, zooecial wall in the neanic and ephebic zone, and the thick diaphragms of the mesopores. Windom member, collection 3548 .

8. Longitudinal section of paratype, USNM 133873, $\times 75$, displaying typical leioclemid wall structure. Windom member, collection 3548 . 


\section{PLATE 5}

Figures 1-3. Trachytoechus variacellus (HัHall) (p. 49).

1a. Longitudinal view of holotype, New York State Museum $827, \times 10$, displaying irregularly undulating zooecial walls, poorly defined zones of thin and thicker-walled growth generally parallel to the surface of the zoarium, and the larger megazooecia near center of figure just to the left of club-shaped acanthopore. Hamilton group, York, N.Y.

1b. Tangential section of holotype, $\times 50$, showing amalgamate wall structure, large acanthopores roughly polygonal in cross section, and large megazooecia.

1c. Longitudinal section of holotype, $\times 50$, displaying a heterophragm in upper left of figure and trachytoechid wall structure.

2a. Tangential section of identified specimen, USNM 133874, $\times 20$, showing typical development of zooecia and acanthopores. Centerfield limestone member of Ludlowville shale, collection 3571.

2 b. Longitudinal section of same specimen, $\times 50$, showing cystiphragms and cystoidal diaphragms of megazooecia accompanied by a granular, brown deposit similar to that reported in Ordovician Trepostomata by Cumings and Galloway, 1915.

2c. Longitudinal section of same specimen, $\times 20$, showing a number of heterophragms.

2 d. Longitudinal section of same specimen, $\times 75$, displaying trachytoechid wall structure and a heterophragm with an even, transparent margin.

3a. Tangential section of identified specimen, USNM $133875, \times 50$, showing numerous fimbriate heterophragms and darkened mural lacunae. Centerfield limestome member, collection 3571

$3 \mathrm{~b}$. Longitudinal section of same specimen, $\times 50$, showing heterophragms and a typical acanthopore displaying abrupt changes in diameter at transverse discontinuities. 


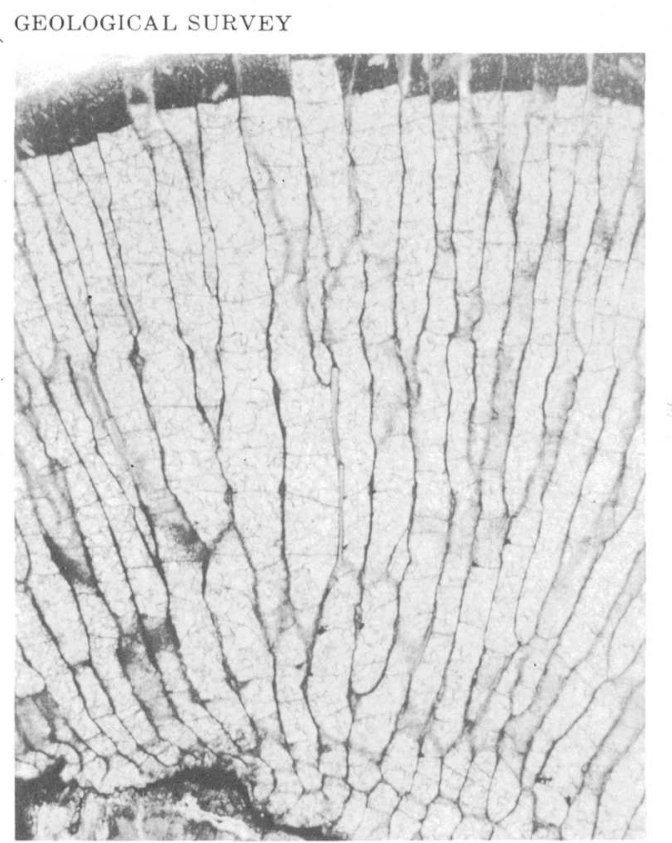

$1 \mathrm{a}$

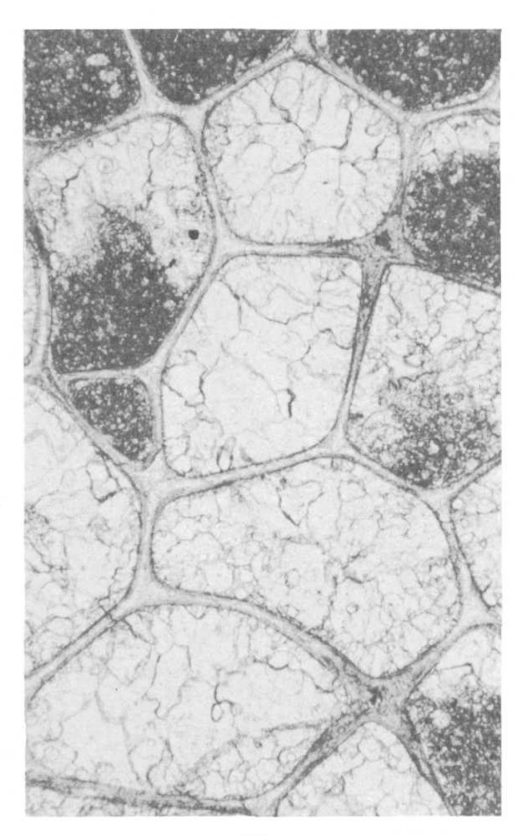

$1 \mathrm{~b}$

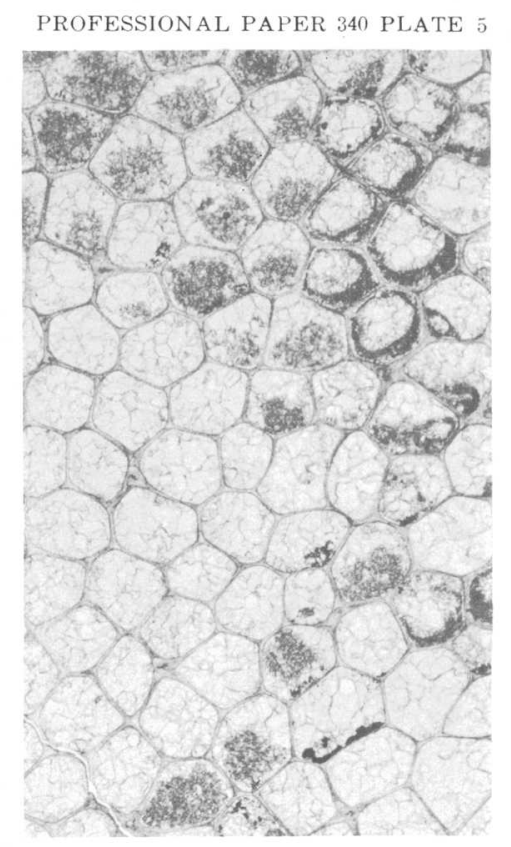

$2 \mathrm{a}$

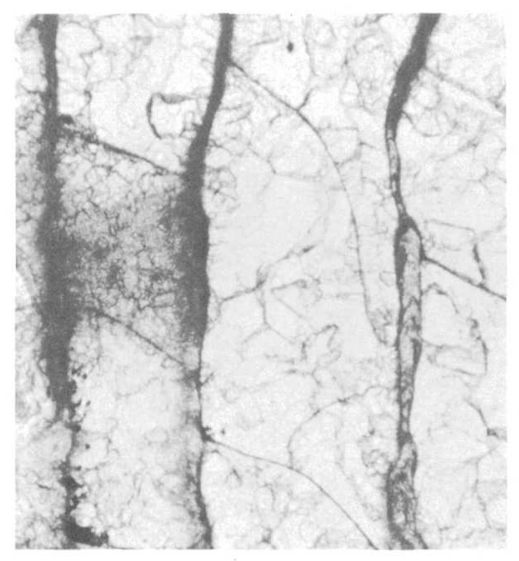

1c

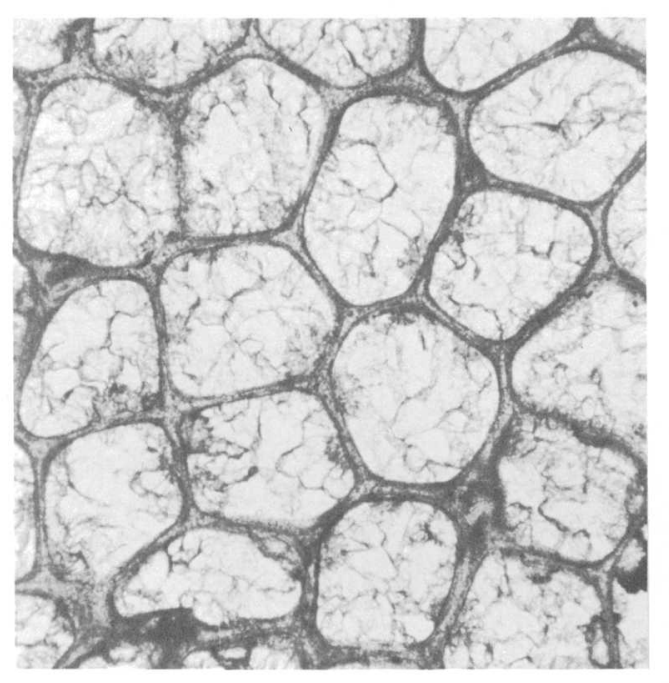

$3 a$

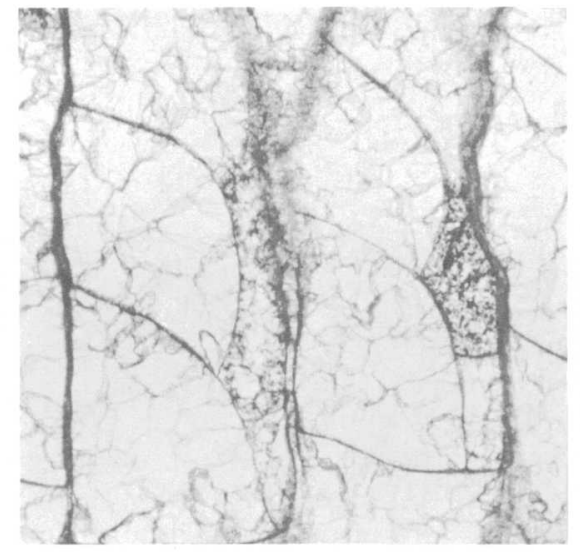

$2 b$

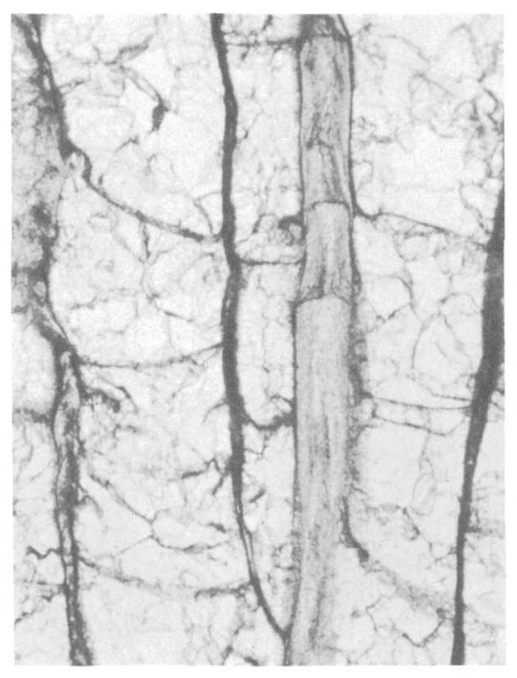

$3 b$

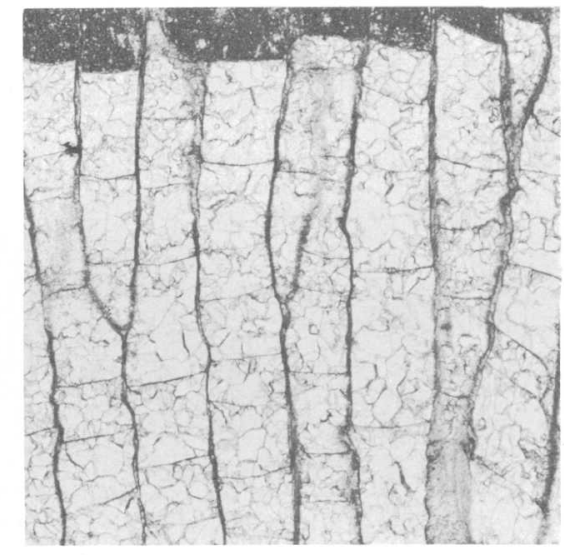

2c

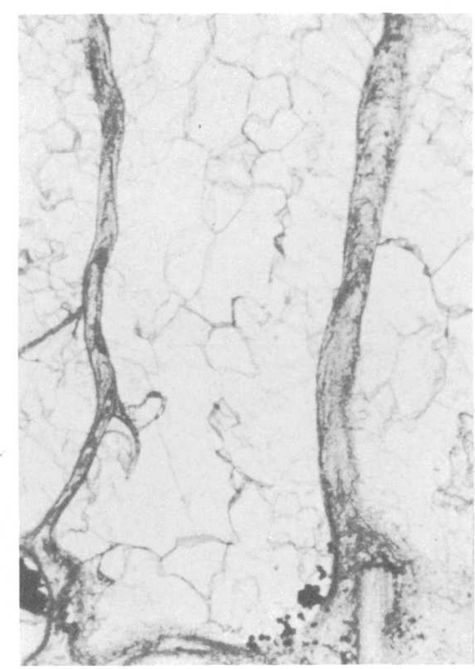

$2 d$

TRACHYTOECHUS VARIACELLUS 


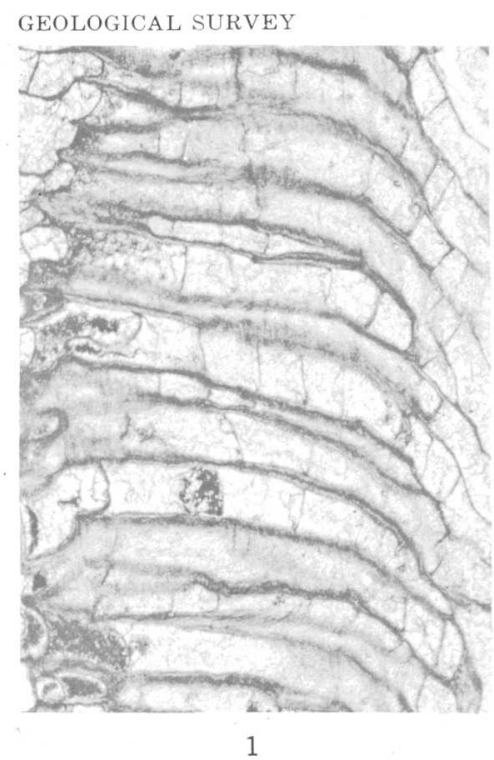

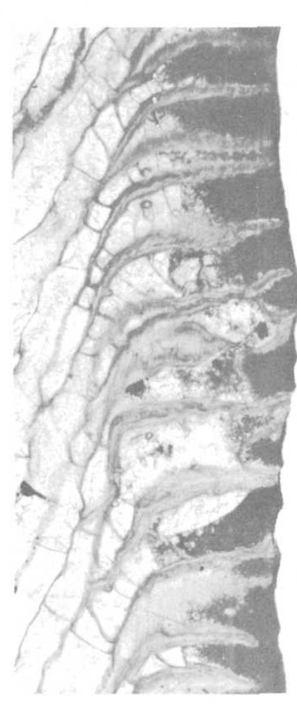

2

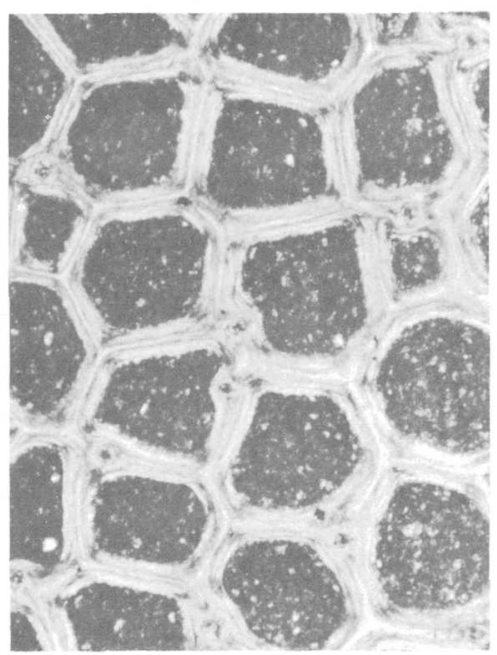

6

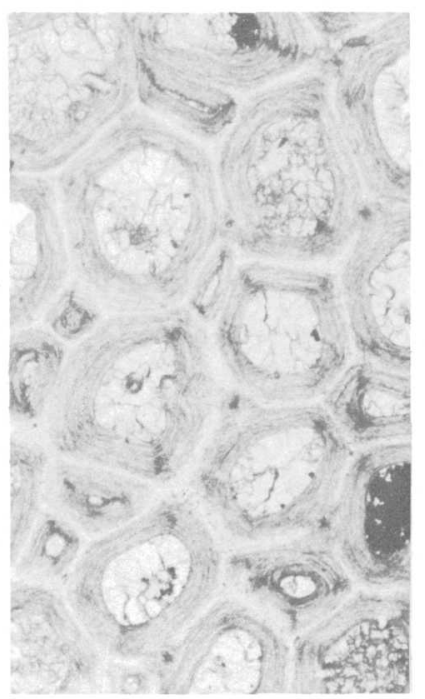

$8 b$

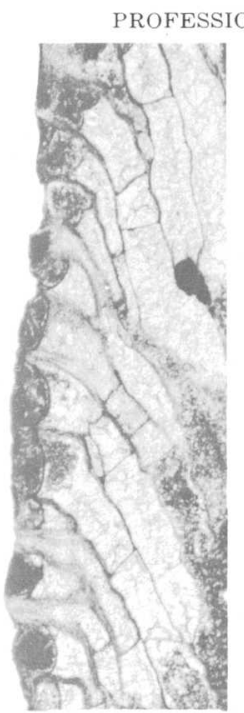

4

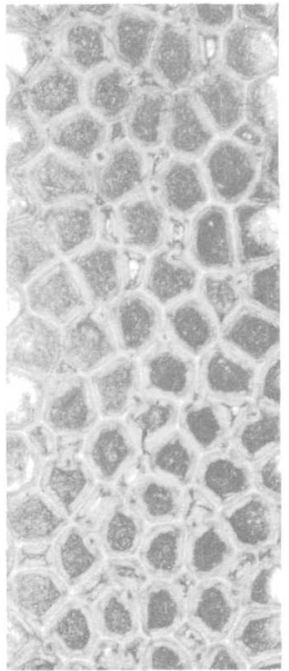

$3 b$

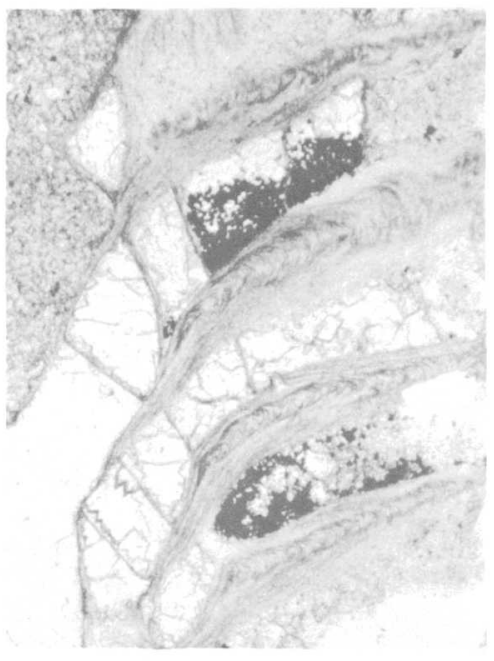

7

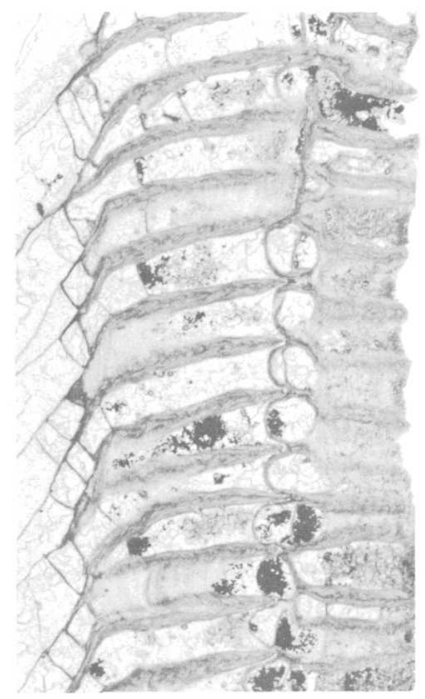

$8 \mathrm{c}$

LEPTOTRYPELLA (LEPTOTRYPELLA) MESOSTENA MESOSTENA, N. SUBSP., AND L. (L.) MESOSTENA PROVECTA, N. SUBSP. 


\section{PLATE 6}

Ficures 1-6. Leptotrypella (Leptotrypella) mesostena mesostena Boardman, n. subsp. (p. 55).

1. Longitudinal section of paratype, USNM 133876, $\times 20$, illustrating growth stage of 7 to 8 diaphragms. Note concentration of mural spines at zooecial bends. Centerfield limestone member of Ludlowville shale, collection 3571.

2. Longitudinal section of paratype, USNM. 133877, $\times 20$, displaying growth stage of 6 to 7 diaphragms. Note extreme constriction of the diameters of the zooecia in the early ephebic zones and as many as 4 diaphragms proximal to the zooecial bends. Centerfield limestone member, collection 3571 .

3a. Longitudinal section of holotype, USNM 133878, $\times 20$, displaying growth stage of 4 diaphragms. Centerfield limestone member, collection 3503.

3b. Tangential section of holotype, $\times 20$, showing typical integrate to narrowly amalgamate appearance of zooecial walls.

4. Longitudinal section of paratype, USNM 1.33879, $\times 20$, showing growth stage of 2 to 3 diaphragms. Centerfield limestone member, collection 3571.

5. Longitudinal section of paratype, USNM 133880, $\times 75$, displaying thick zooecial lining and mural spines. Centerfield limestone member, collection 3503 .

6. Tangential section of paratype, USNM $133881, \times 50$, showing integrate wall structure and acanthopores inflecting the zooecial walls. Centerfield limestone member, collection 3571 .

7, 8. Leptotrypella (Leplotrypella) mesostena provecta Boardman, n. subsp. (p. 56).

7. Longitudinal section of paratype, USNM 133882, $\times 50$, showing thick zooecial lining and well defined zone of curved laminae, typical leptotrypellid wall structure. Ledyard member (of Cooper, 1930) of Ludlowville shale, collection 3541 .

8i. Longitudinal section of holotype, USNM $133883, \times 50$, showing thick zooecial lining, mural spines, and conspecific overgrowth with reversed zooecial orientation. Circles in zooecial voids are zooecial spines cut transversely. Ledyard member, collection 3541.

8b. Tangential section of holotype, $\times 50$, showing concentration of mesopores in monticule and narrowly amalgamate to integrate wall structure. Note mural lacunae in amalgamate zones.

8 c. Longitudinal view of holotype, $\times 20$, showing constriction of zooecial diameter and $2-4$ diaphragms in early ephebic zone proximal to the sharp zooecial bends. 


\section{PLATE 7}

FiguRes 1-4. Leptotrypella (Leptotrypella) multitecta Boardman, n. sp. (p. 57).

1a. External view of paratype, USNM $133884, \times 1$. Small nodes on branches are monticules, on this zoarium fairly high. Arrows indicate positions in the zoarium of corresponding thin sections. Wanakah shale member (as used by Buehler and Tesmer, in press) of Ludlowville shale collection 3512 .

1b. Longitudinal section of fragment just below growing tip of same zoarium, $\times 20$, showing growth stage of 3 diaphragms.

1c. Longitudinal section of fragment at base of same zoarium, $\times 20$, showing growth stage of 8 to 9 diaphragms.

1d. Tangential section from same zoarium, $\times 20$, showing megazooecia of monticule in lower right of figure.

2. Longitudinal view of paratype, USNM $133885, \times 10$, showing a growing tip with a terminating ephebic zone of 2-3 diaphragms. Note abandoned growing tip arching across neanic region that contains just one diaphragm and remnants of zooecial wall thickening. Wanakah shale member, collection 1017.

3. Longitudinal view of paratype, USNM 133886, $\times 41 \frac{1}{2}$, showing a zoarium incrusting a Pleurodictyum and also developing a ramose growth habit. Wanakah shale member, collection 3565 .

4a. Longitudinal view of holotype, USNM 133887, $\times 5$, showing origin and typical development of overgrowth. Zooecia of primary or supporting branch are extended distally without interruption at origin, or, most proximal area of secondary growth. The secondary growth is in all directions, incrusting downward on the primary branch with zooecia in reversed orientation (upside down relative to zooecia of primary branch) and a branch beyond the primary growing tip that effectively extends the length of the zoarium. Wanakah shale member, collection 3524 .

4b. Longitudinal view of holotype, $\times 20$. Note early ephebic zone without marked constriction of zooecial diameter and containing 2-3 diaphragms. Also, zooecial bend is flattened and poorly defined.

$4 \mathrm{c}$. Tangential view of holotype, $\nsim 20$, displaying amalgamate zooecial walls and numerous mesopores. 
GEOLOGICAL SURVEY

PROFESSIONAL PAPER 340 PLATE 7

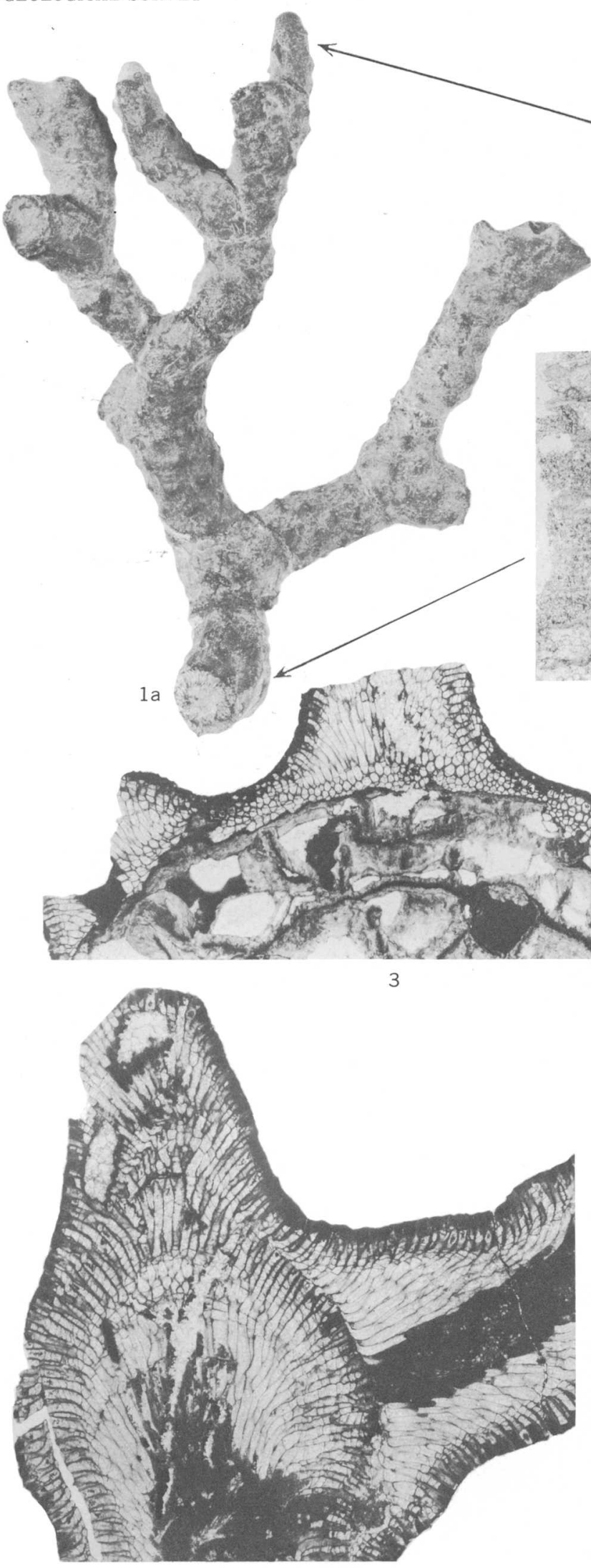

$4 a$

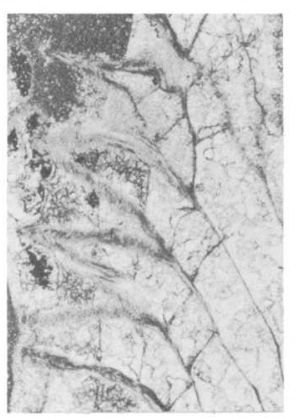

$1 b$

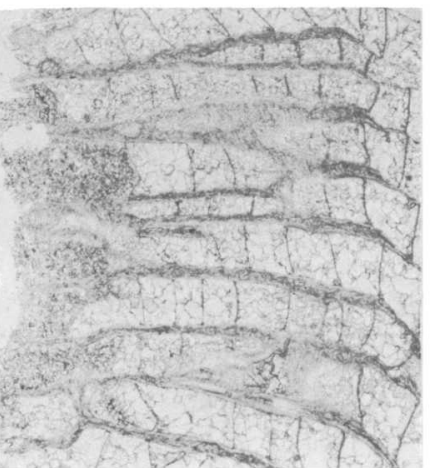

$1 \mathrm{c}$
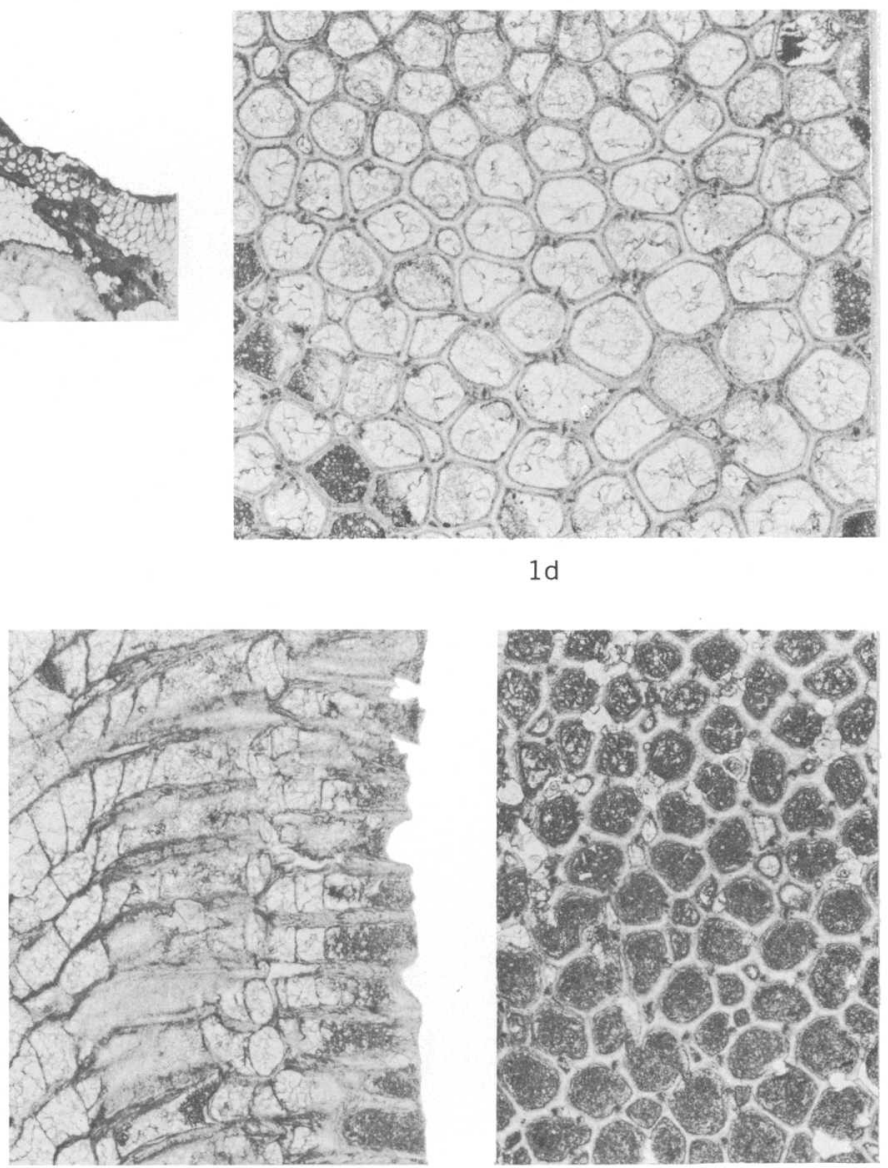

$4 b$
$1 d$

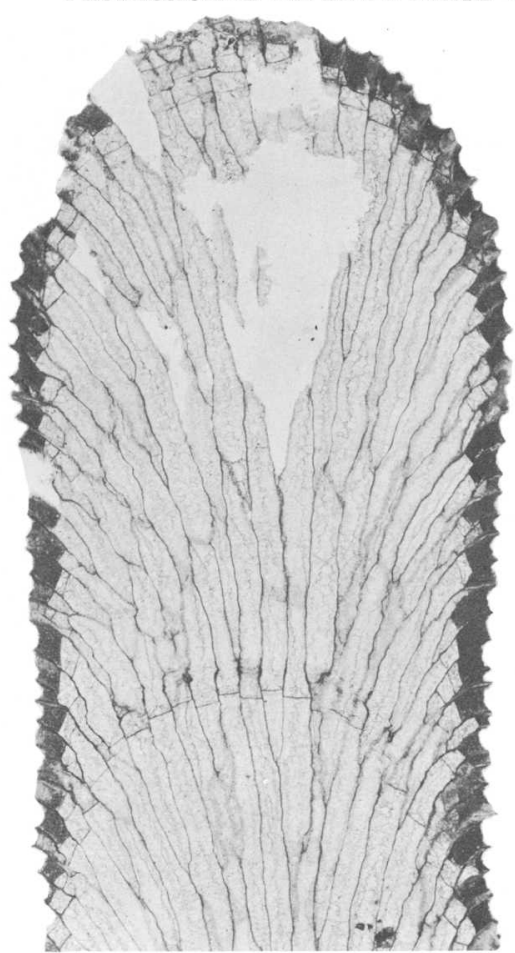

2

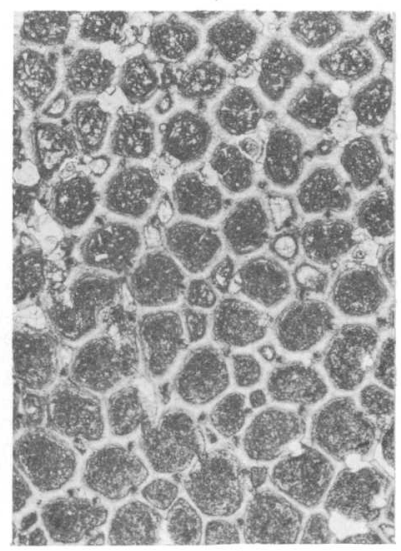

$4 c$

LEPTOTRYPELLA (LEPTOTRYPELLA) MULTITECTA, N. SP. 
GEOLOGICAL SURVEY

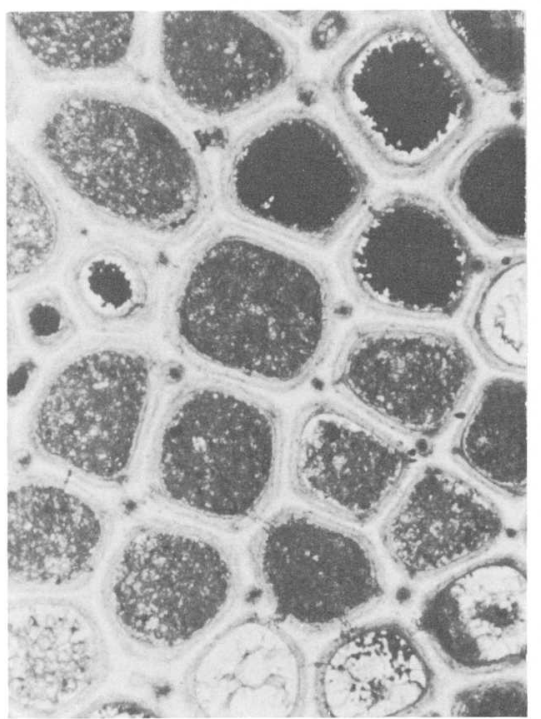

1 a

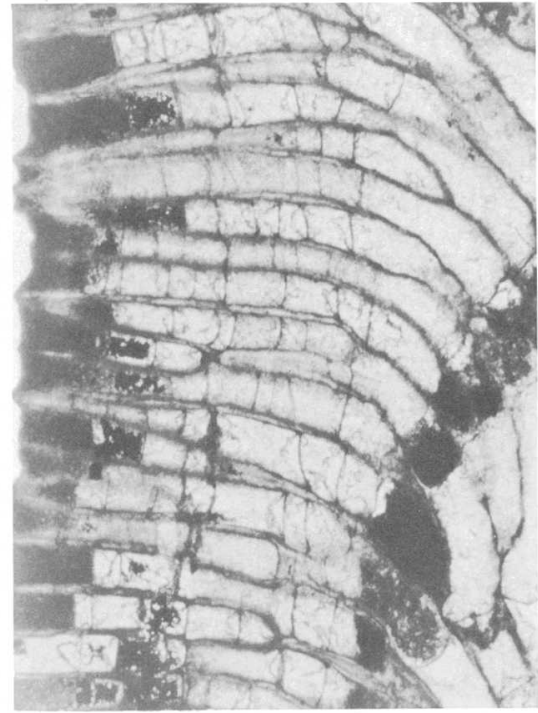

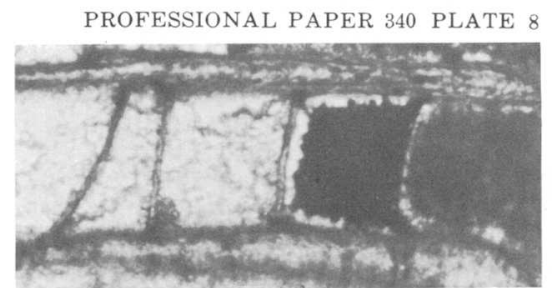

$1 \mathrm{~b}$

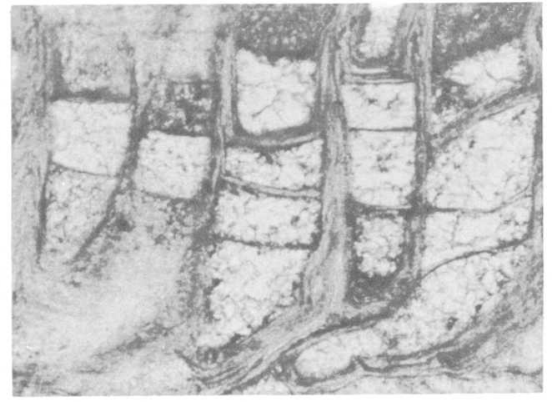

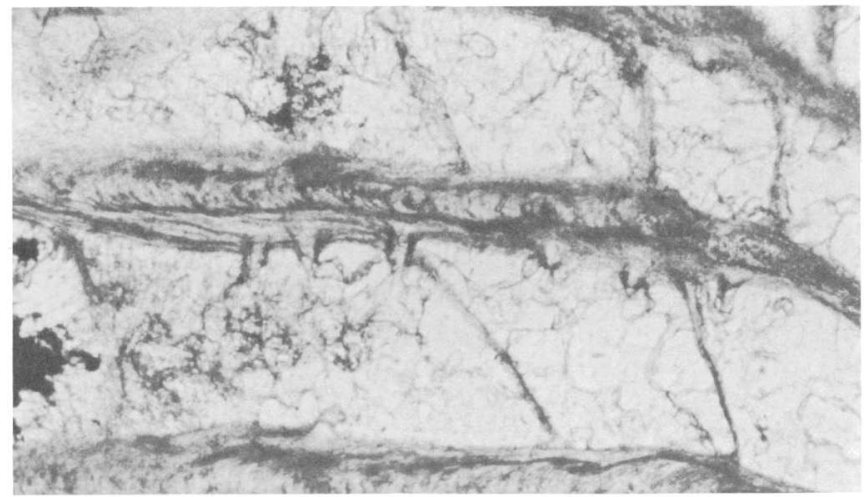

4

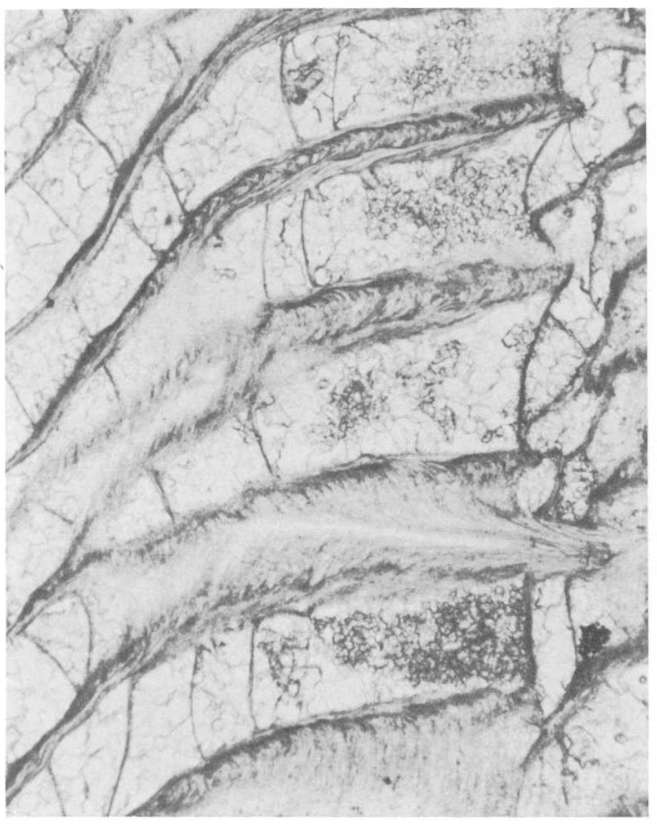

$5 b$

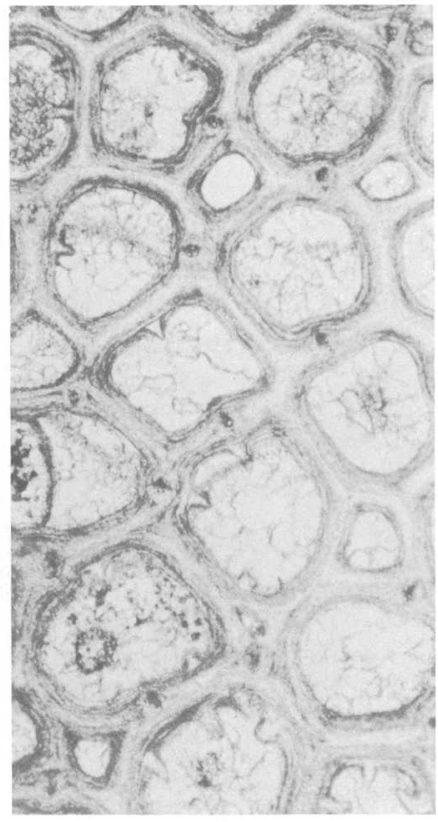

6

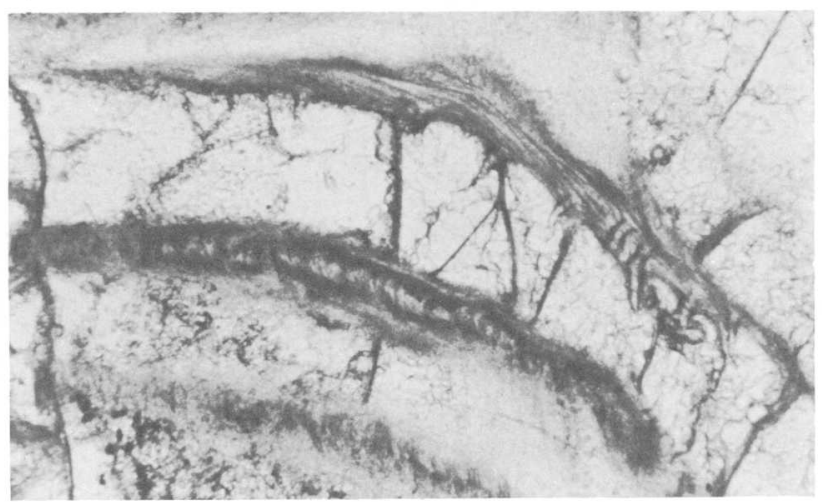

$5 a$

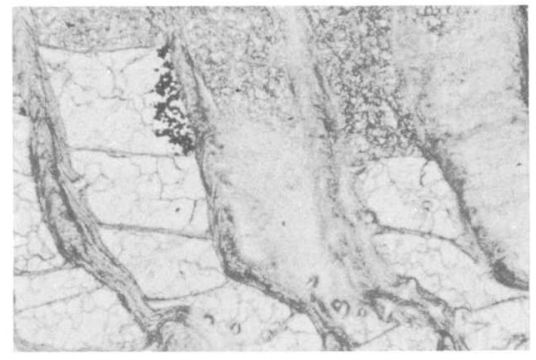

7

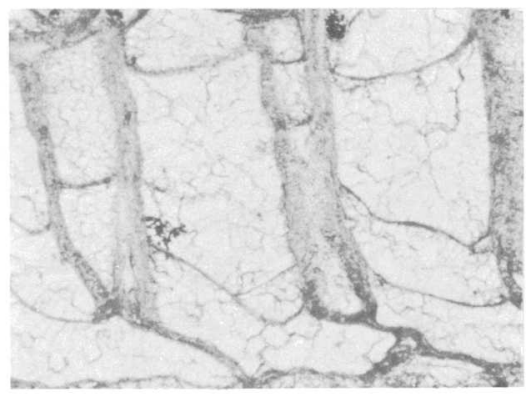

8

LEPTOTRYPELLA (LEPTOTRYPELLA) BARRANDI AND L. (L.) MULTITECTA, N. SP. 


\section{PLATE 8}

Figures 1, 2. Leptotrypella (Leptotrypella) barrandi (Nicholson) (p. 53).

1a. Tangential view of identified specimen, USN M $26588, \times 50$, displaying amalgamate wall structure, small acanthopores, and a cluster of three mesopores in monticule. Widder formation, Thedford, Ontario.

1b. Longitudinal view of same specimen, $\times 75$, showing leptotrypellid wall structure consisting of zooecial lining and zone of curved laminae.

2. Longitudinal view of identified specimen, USNM 133888, showing abandoned and eroded growing tip and thin, planar diaphragms. Widder formation, Thedford, Ontario.

3-8. Leptotrypella (Leptotrypella) multitecta Boardman, n. sp. (p. 57).

3. Longitudinal view of paratype, USNM $133889, \times 50$. Figures 3,7 , and 8 are included on this plate to illustrate the extreme morphologic variation common in incrusting zoaria of this species. This zooecia in this figure develop abnormally thick diaphragms and lose the leptotrypellid appearance of their walls in this part of the zoarium. Wanakah shale member (as used by Buehler and Tesmer, in press), of Ludlowville shale collection 3511.

4. Longitudinal view of holotype, USNM 133887, $\times 100$, showing relationship of mural spines to laminae of zooecial lining. Note base of distally placed spines connected with progressively younger laminae. Distal direction to left of figure. Wanakah shale member, collection 3524 .

5a. Longitudinal section of paratype, USNM $133890, \times 75$, showing abnormally long mural spines. Wanakah shale member, collection 3519 .

5b. Longitudinal section of same specimen, $\times 50$, displaying well preserved leptotrypellid wall structure and an acanthopore trending at an angle to the zooecia.

6. Tangential section of paratype, USNM $133886, \times 50$, showing mural spines in tangential view. Note acanthopores distributed between zooecial corners and inflecting zooecial walls. Wanakah shale member, collection 3565 .

7. Longitudinal section of paratype, USN M $133891, \times 50$, showing typical appearance of incrusting zooecia of species: Note the typical concentration of mural spines near the basal lamina and the early ephebic zone. Wanakah shale member, collection 3524 .

8. Longitudinal section of paratype, USNM $133892, \times 50$, showing diaphragms of irregular configuration and abnormally thin zooecial walls lacking a zooecial lining. Wanakah shale member, collection 3514 . 


\section{PLATE 9}

Figure 1. Leptotrypella (Leptotrypella) asterica Boardman, n. sp. (p. 58).

1a. External view of partly reconstructed zoarium of holotype, USNM $133893, \times 3 / 10$. Numbers in figure indicate positions in the zoarium of corresponding thin sections illustrated in the plate. Kashong member (of Cooper, 1930) of Moscow shale, collection 3543.

1b. Longitudinal section of holotype taken from growing tip, $\times 20$, and illustrating growth stage of 3-5 diaphragms.

1c. Longitudinal section of holotype taken from position approximately $1 / 3$ down from distal end, $\times 20$, showing growth stage of 7-9 diaphragms.

1d. Longitudinal section of holotype taken near base of zoarium, $\times 20$, showing growth stage of 12-14 diaphragms. Note concentration of cysts.

1e. Longitudinal view of growing tip of holotype, $\times 3$, showing growth stage of approximately 3-5 diaphragms and correspondingly narrow ephebic zones. Note the traces of a series of partly resorbed, abandoned growing tips arching across neanic zone.

1f. Longitudinal view of fragment near base of holotype, $\times 3$, illustrating growth stage of approximately 12 diaphragms. Note the rapid increase in width of the neanic zone distally as the branch approaches a normal bifurcation. The ephebic zone remains relatively constant in width.

1g. Tangential section of holotype, $\times 50$, showing amalgamate walls typical of the species.

1h. Longitudinal section of holotype, $\times 15$, showing growth stage of $9-10$ diaphragms and a profile view of a "starshaped" prominence.

1j. Tangential section of holotype, $\times 20$, showing "star-shaped" prominence. 
GEOLOGICAL SURVEY
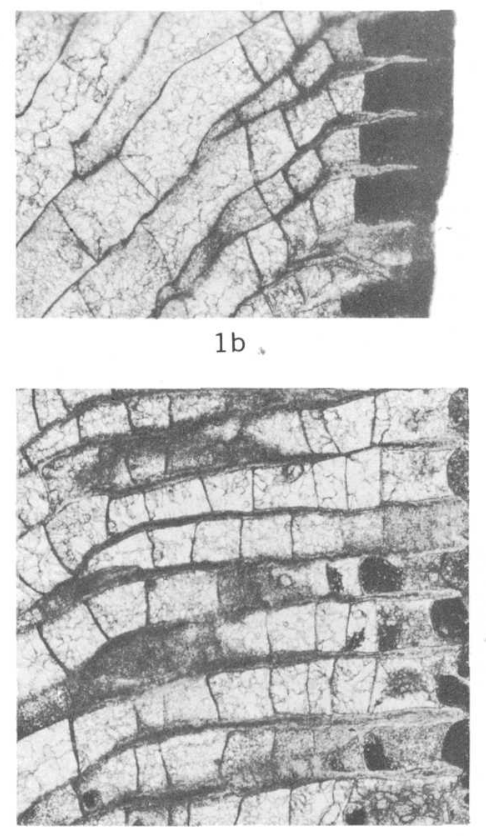

$1 c$

PROFESSIONAL PAPER 340 PLATE 9
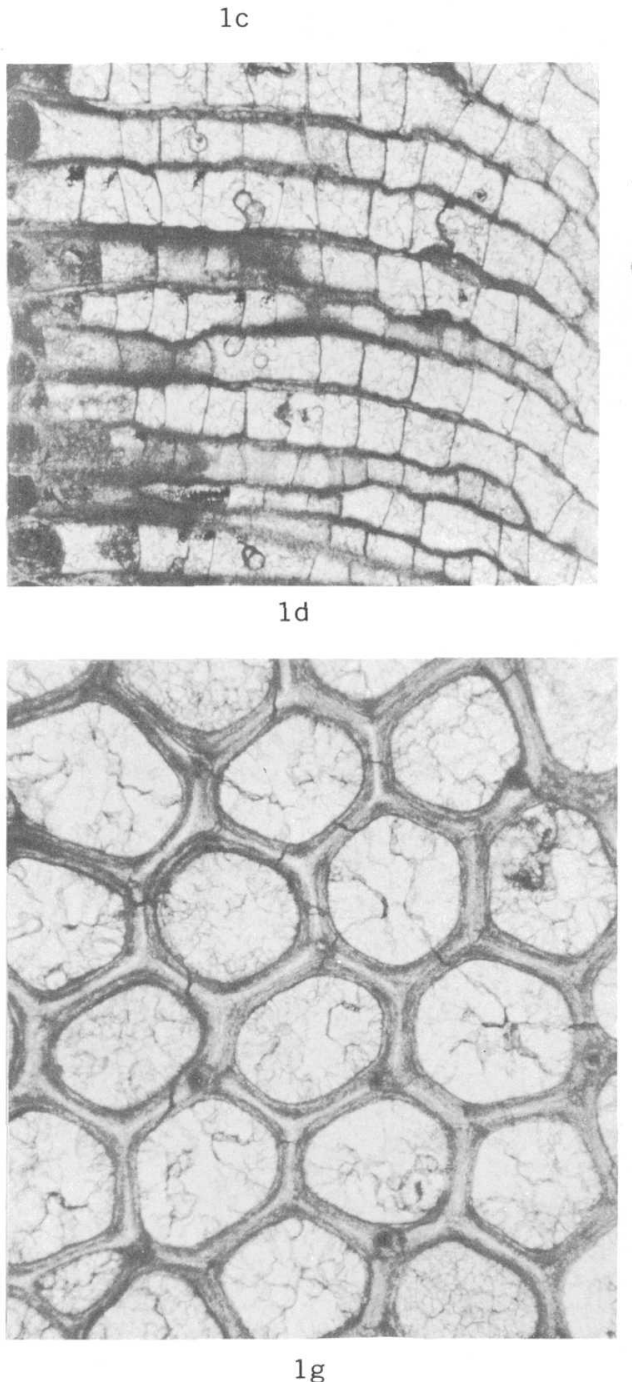

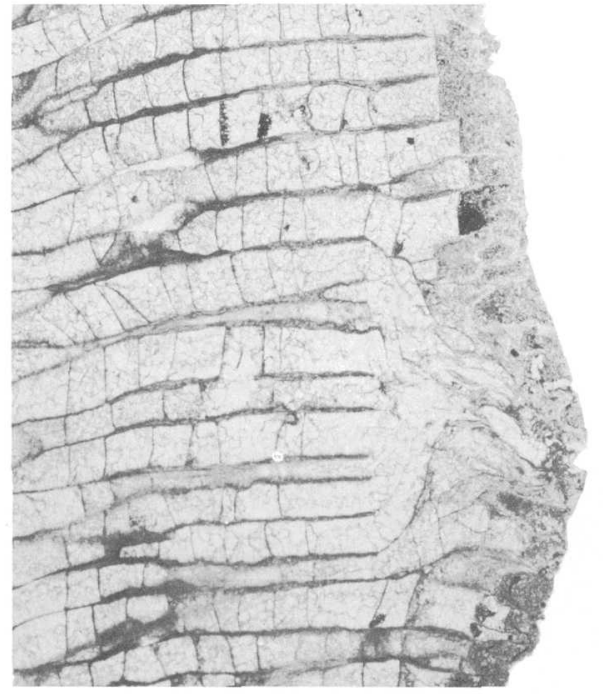

1h

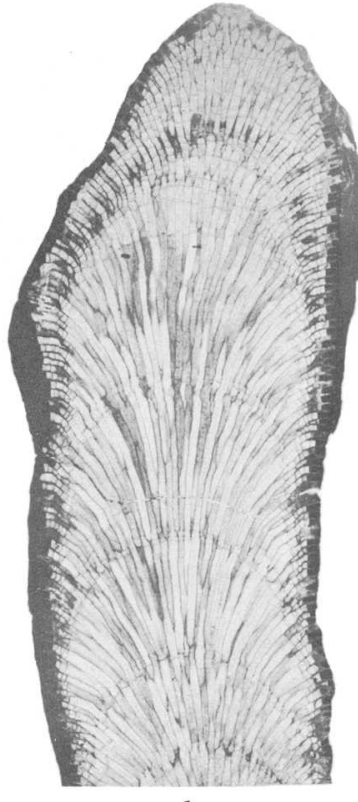

$1 \mathrm{e}$
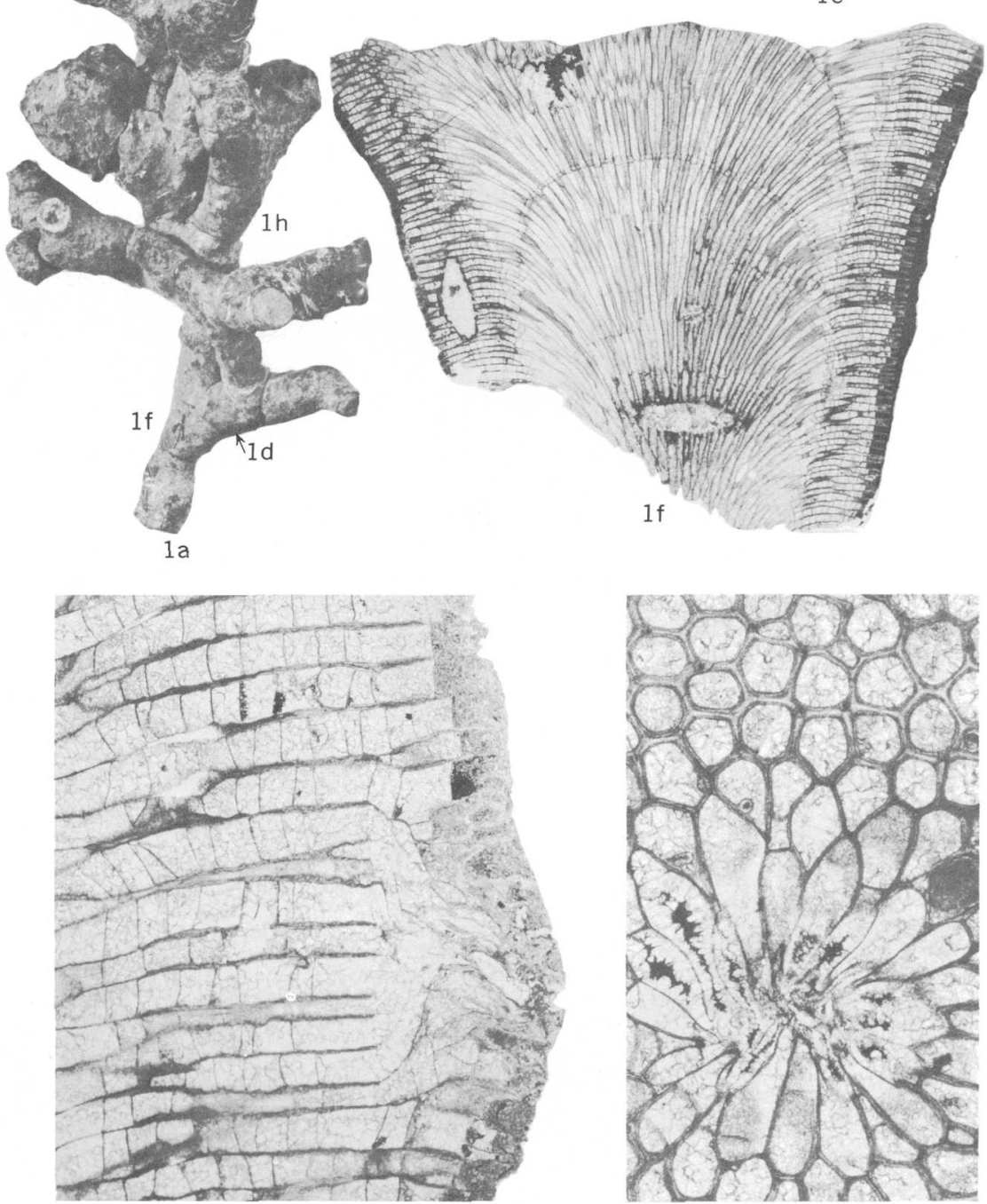

$1 \mathrm{i}$

LEPTOTRYPELLA (LEPTOTRYPELLA) ASTERICA, N. SP. 
GEOLOGICAL SURVEY

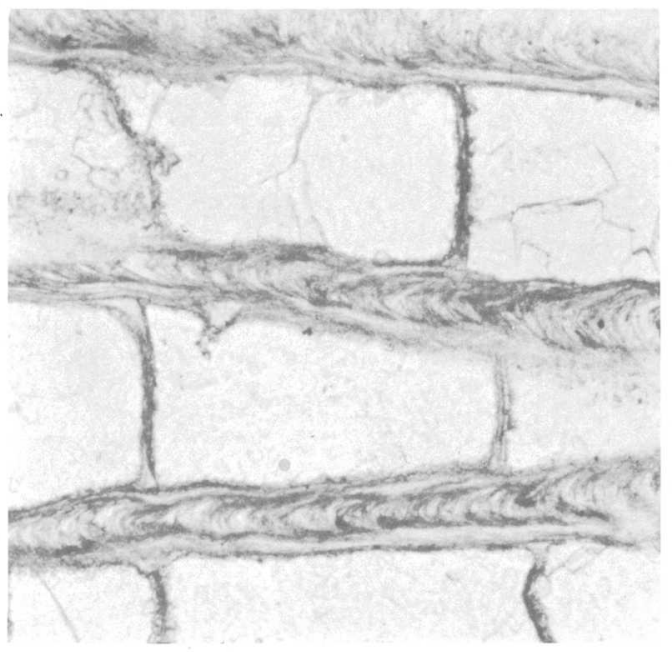

$1 a$
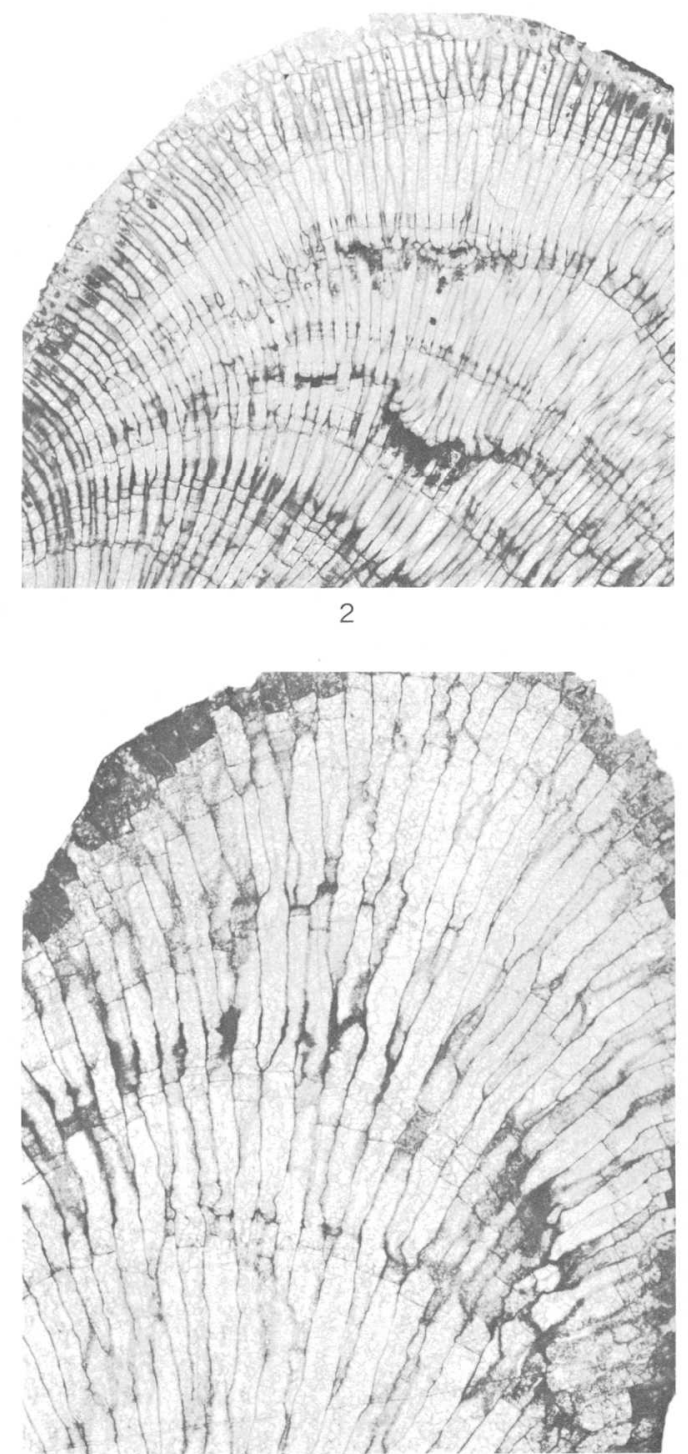
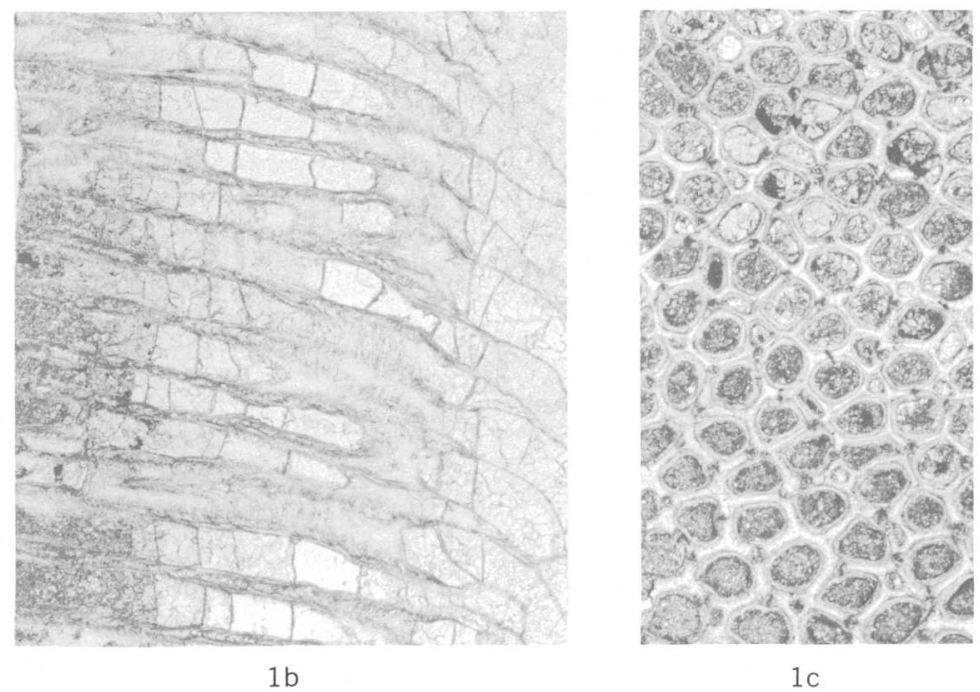

$1 \mathrm{c}$

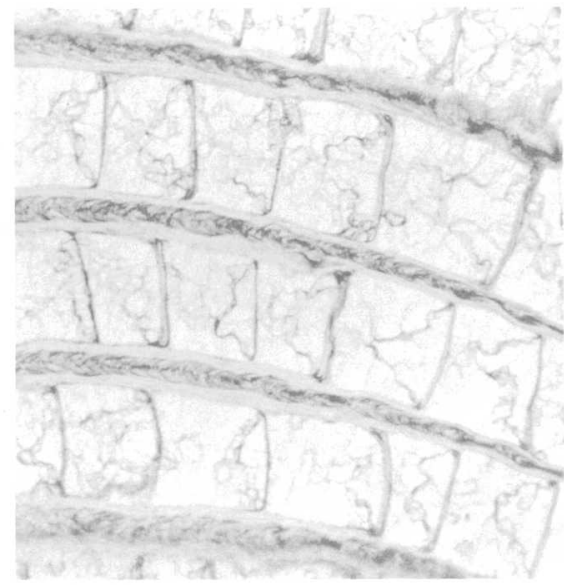

3

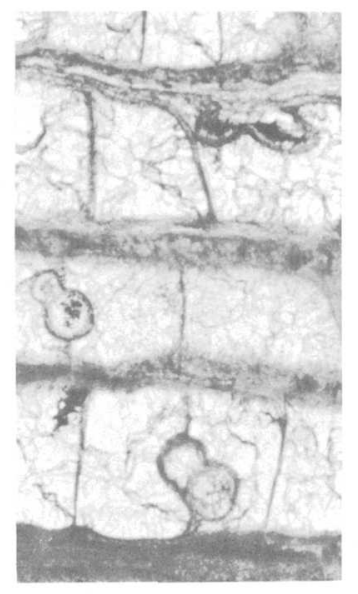

4

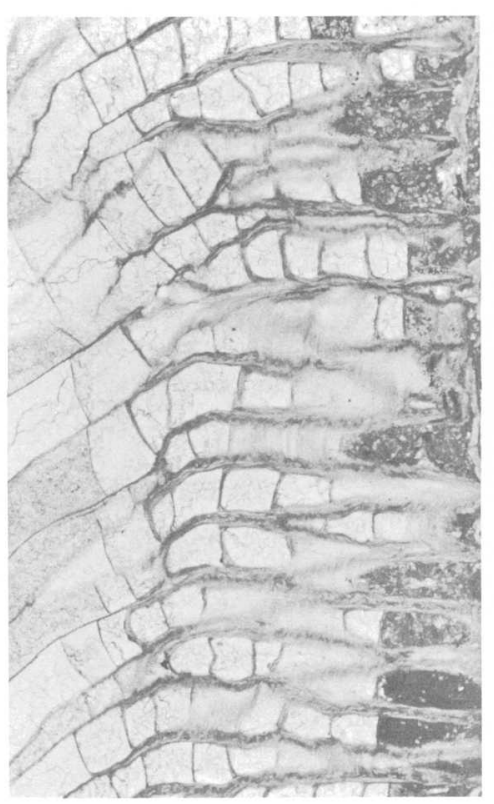

$6 a$

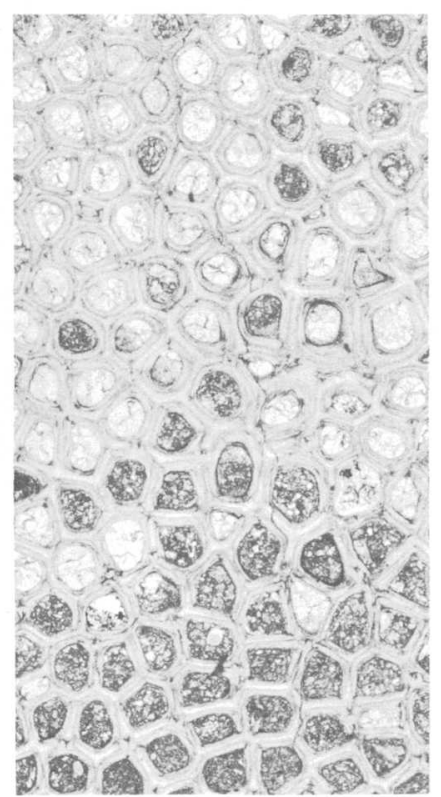

$6 b$

LEPTOTRYPELLA (LEPTOTRYPELLA) ASTERICA, N. SP. 


\section{PLATE 10}

Figures 1-6. Leptotrypella (Leptotrypella) asterica Boardman, n., sp. (p. 58).

1a. Longitudinal view of paratype,. USNM $133894, \times 100$, showing leptotrypellid wall containing moderately thin zooecial lining and distinct zone of curved laminae. King Ferry shale member (of Cooper, 1930) of Ludlowville shale, collection 3572 .

1b. Longitudinal view of same specimen, $\times 20$, showing widely spaced diaphragms typical of variants with thin zooecial linings.

1c. Tangential view of same specimen, $\times 20$, displaying broadly amalgamate walls, consistent with leptotrypellid walls containing wide zones of curved laminae.

2. Longitudinal view of paratype, USNM 133895, $\times 5$, showing almost entire length of stunted branch that appears as a knob on the zoarium. Note the series of abandoned ephebic zones represented by their proximal parts only. Kashong member (of Cooper, 1930) of Moscow shale, collection 3501.

3. Longitudinal view of paratype, USNM $133896, \times 50$, displaying variant with thick zooecial linings and regularly and more closely spaced diaphragms. Kashong member, collection 3501 .

4. Longitudinal section of holotype, USNM 133893, $\times 50$, showing relationship of cysts to diaphragms and zooecial walls. Kashong member, collection 3543 .

5. Longitudinal section of paratype, USNM $133897, \times 10$, showing growing tip and proximal position of abandoned growing tips in which the amount of resorption was variable. Kashong member, collection 3501.

6a. Longitudinal section of paratype, USNM 133898, $\times 20$, illustrating thick zooecial walls and abnormally thick diaphragms. Portland Point member (of Cooper, 1930) of Moscow shale, collection 3563.

6b. Tangential section of same specimen, $\times 20$, showing thick, broadly amalgamate walls and a monticule marked by zooecia with still thicker walls. 


\section{PLATE 11}

FigURES 1-6. Leptotrypella (Leptotrypella) furcata (Hall) (p. 59).

1a. Longitudinal view of lectotype, New York State Museum $6187, \times 50$, displaying leptotrypellid walls with little or no zooecial lining and thin planar diaphragms. Hamilton group, Bellona, New York.

1b. Tangential section of lectotype, $\times 50$, showing broadly amalgamate zooecial walls that contain mural lacunae, and abnormally large acanthopores.

2. Longitudinal section of identified specimen, USNM 133899, $\times 20$, illustrating growth stage of $1-3$ diaphragms. Windom member of Moscow shale, collection 3569.

3a. Tangential section of identified specimen, USNM $133900, \times 100$, showing broadly amalgamate walls and mural lacunae. Windom member, collection 3562 .

$3 \mathrm{~b}$. Tangential section of same specimen, $\times 20$. Shows monticule with concentration of mesopores surrounded by megazooecia, all with thickened walls.

3c. Longitudinal section of same specimen, $\times 20$. Shows growth stage of 7-10 diaphragms, and several subspherical cysts attached to diaphragms. Note overgrowth with zooecia in reversed orientation.

4. Tangential view of identified specimen, USNM 133901, $\times 20$, showing monticule without the central concentration of mesopores. Windom member, collection 3553 .

5a. Longitudinal section of identified specimen, USNM 133902, $\times 100$, showing mural spine and leptotrypellid wall structure without a distinct zooecial lining. Windom member, collection 3570 .

5 b. Longitudinal section of same specimen, $\times 20$, illustrating growth stage of $6-8$ diaphragms.

6. Longitudinal view of identified specimen, USNM $133903, \times 10$, ilustrating a zoarium incrusting upon a crinoid stem and also forming a branch at right side of figure. Windom member, collection 3569 . 


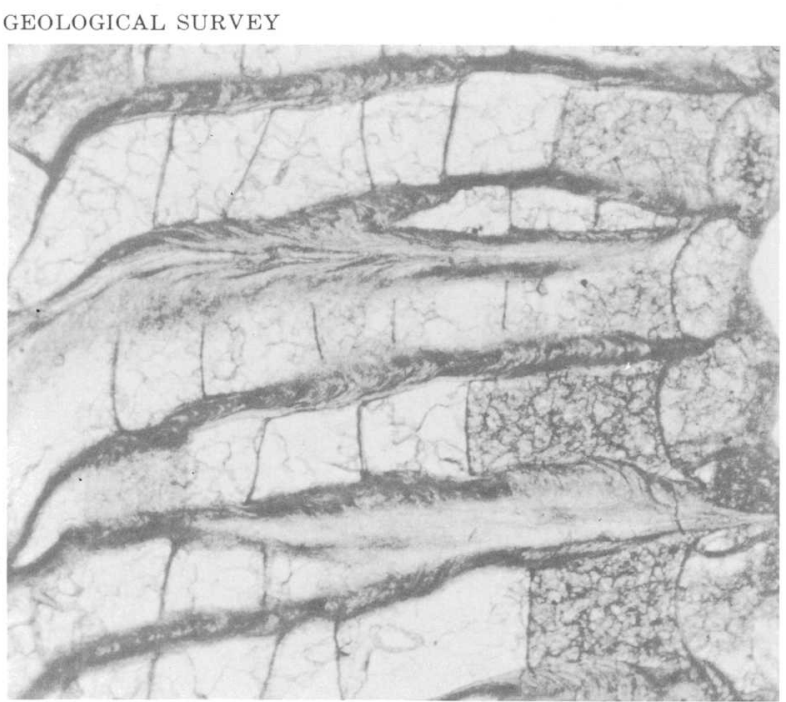

1 a

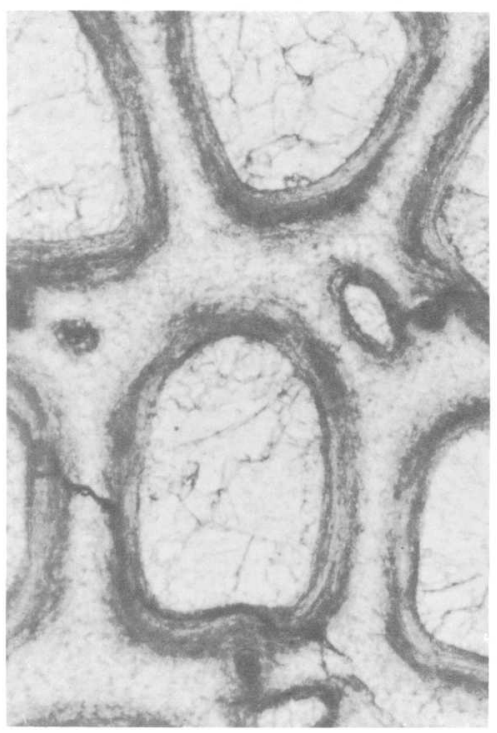

$3 a$

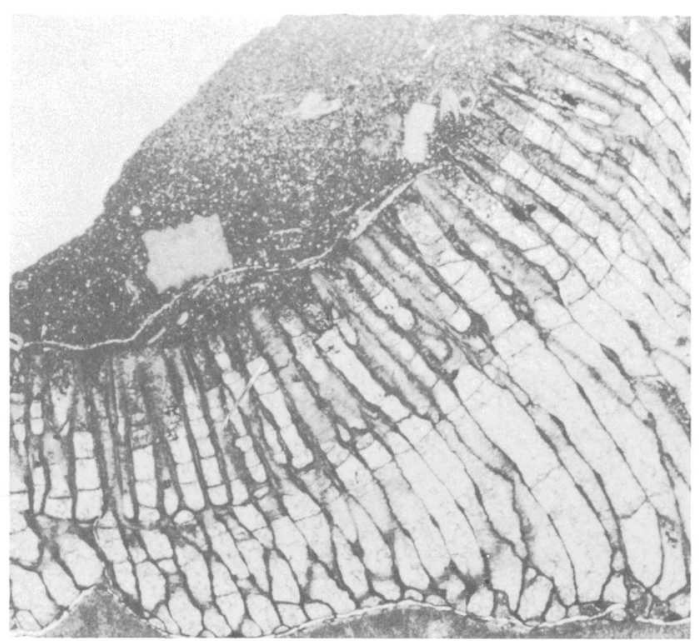

6

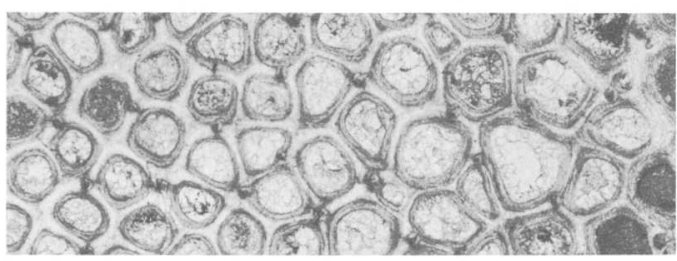

4

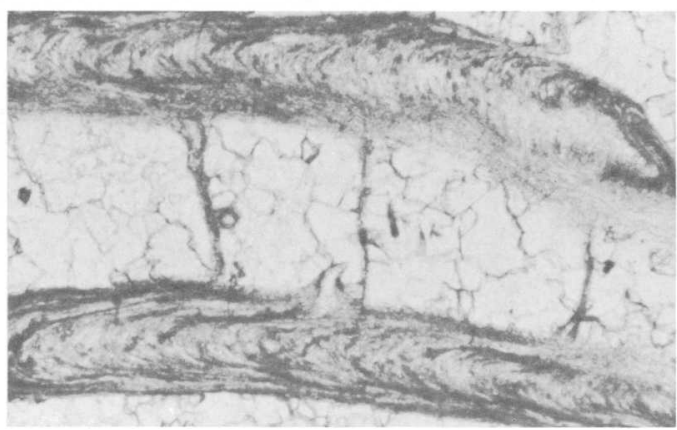

$5 a$

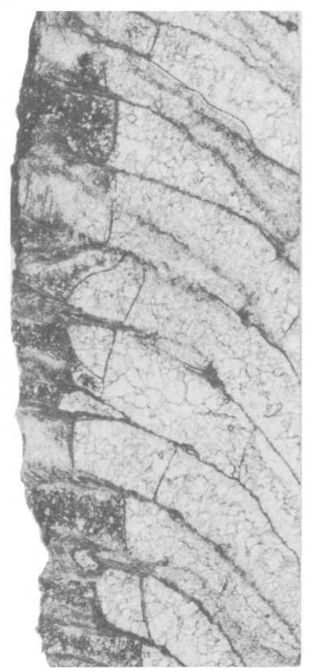

2

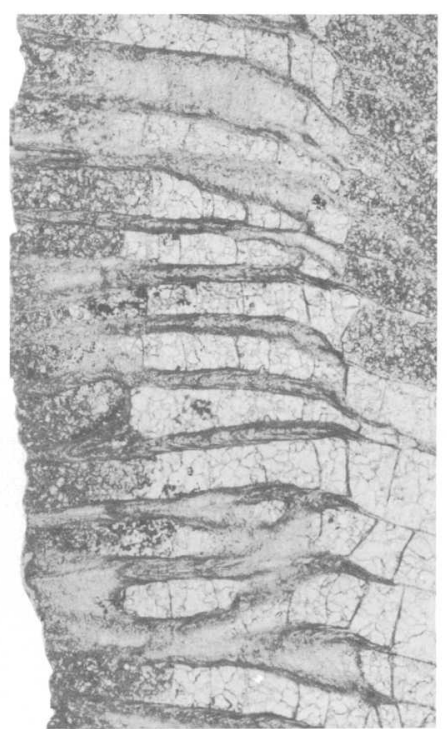

$5 b$

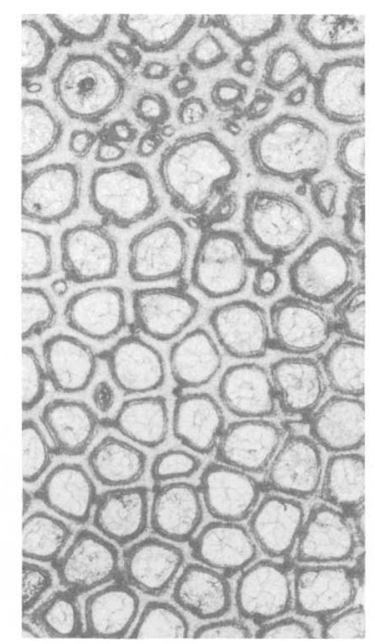

$3 \mathrm{~b}$

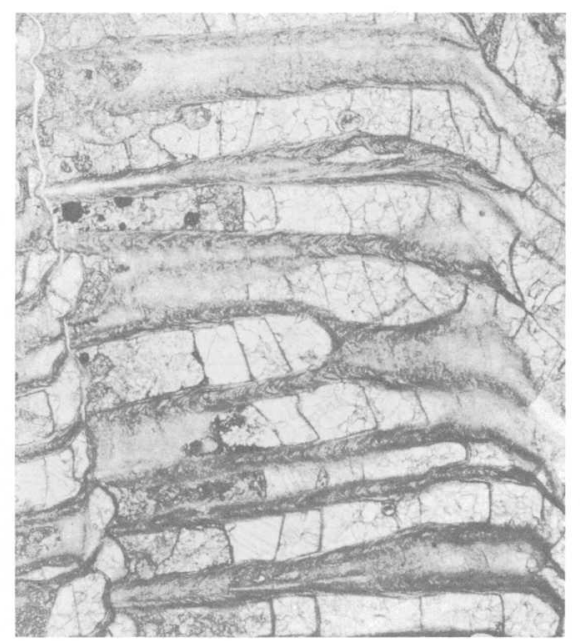

$3 c$

LEPTOTRYPELLA (LEPTOTRYPELLA) FURCATA 

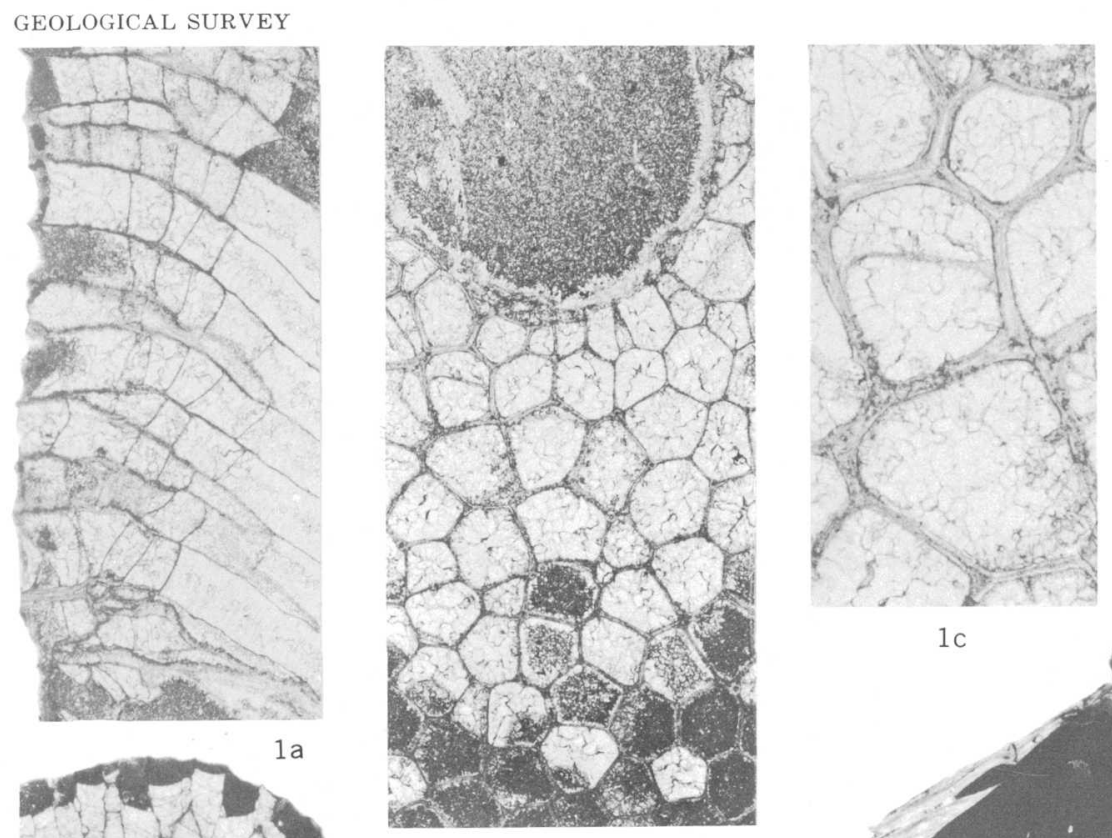

PROFESSIONAL PAPER 340 PLATE 12
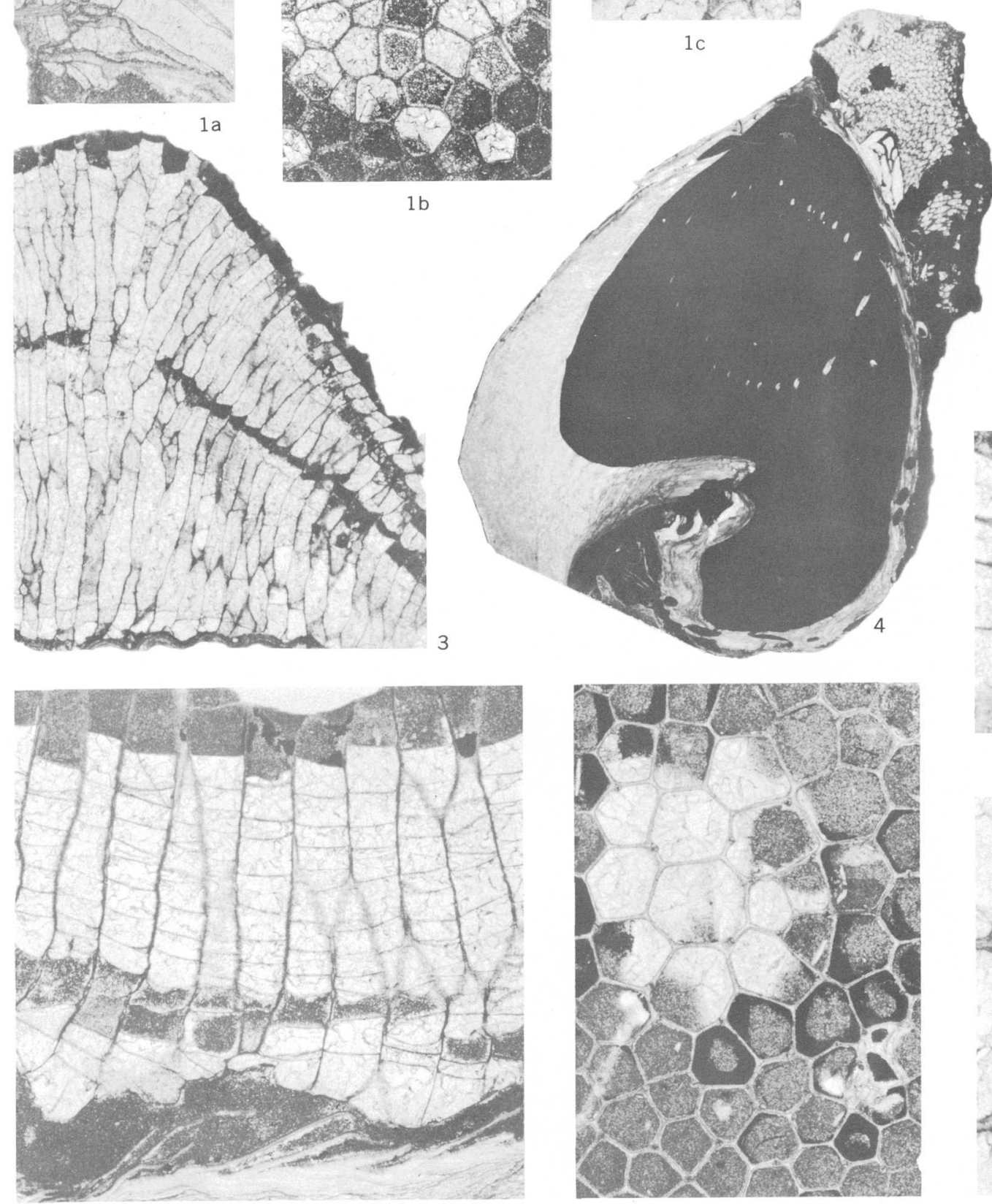

$7 b$
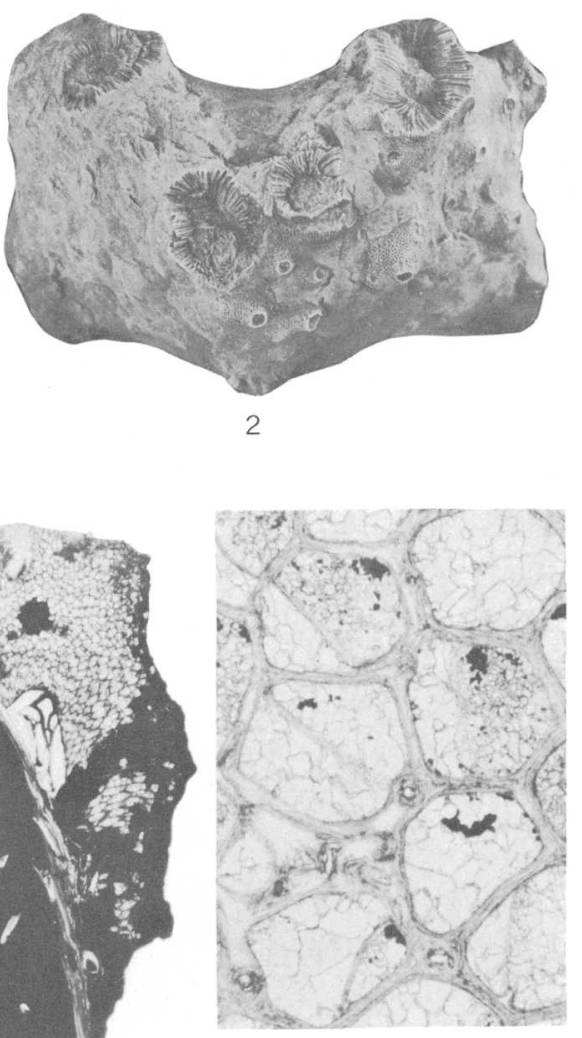

5

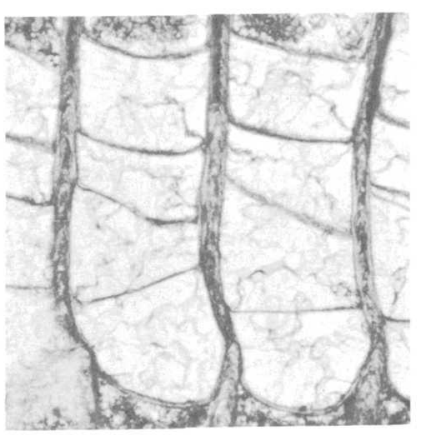

6

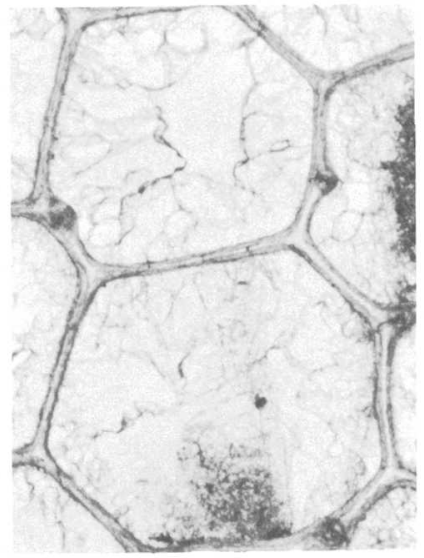

$7 \mathrm{C}$

LEPTOTRYPELLA (LEPTOTRYPELLA) AMPLECTENS AND L. (L.) MAGNIPORTA, N. SP. 


\section{PLATE 12}

Figures 1-5. Leptotrypella (Leptotrypella) amplectens (Grabau) (p. 60).

1a. Longitudinal view of ramose part of identified specimen, USNM $133904, \times 20$, showing generally thin walls of ephebic zone. Wanakah shale member (as used by Buehler and Tesmer, in press) of Ludlowville shale, collection 3502.

1b. Tangential view of same specimen, $\times 20$, showing aperture of associated corallite in upper part of figure and polygonal zooecia surrounding the corallite.

1c. Tangential view of same specimen, $\times 50$, showing the narrowly amalgamate zooecial walls and small mural spines.

2. External view of identified specimen, USNM 72856, XI, showing the circular corallites surrounded by smaller zooecia and the bases of four branches of the coral-bryozoan complex at the anterior end of the supporting brachiopod. Wanakah shale member, Hamburg-on-the-Lake, New York.

3. Longitudinal section of identified specimen, USNM $133905, \times 7.5$, cut parallel to the hingeline of the brachiopod. Note irregularly undulating zooecial walls, abandoned growing surface with zooecia filled with mud, and thick and thinwalled developments in zones generally parallel to the zoarial surface. Wanakah shale member, collection 3519 .

4. Longitudinal section through brachiopod and incrusting colony, USNM 133906, $\times 2$, illustrating position of incrusting complex on the brachial valve. The figure is oriented on the plate to approximate one possible living position of the brachiopod. Wanakah shale member, collection 1017.

5. Tangential section of identified specimen, USNM 133907, $\times 50$, showing thickened walls of zooecia and enlarged acanthopores in a monticule. Wanakah shale member, collection 1017.

6, 7. Leptotrypella (Leptotrypella) magniporta Boardman, n. sp. (p. 61).

6. Longitudinal section of paratype, USNM $133908, \times 50$, displaying abnormally thick zooecial walls for the species. The wall structure is typically leptotrypellid and includes an appreciable zooecial lining. Windom member of Moscow shale, collection 3585 .

7 a. Longitudinal section of holotype, USNM 133909, $\times 20$. Note close spacing of diaphragms throughout vertical ephebic zone. Wanakah shale member, collection 3516 .

7b. Tangential section of holotype, $\times 20$, showing sharply polygonal cross sections of thinwalled zooecia and the extremely large megazooecia of a monticule.

7c. Tangential section of holotype $\times 50$, showing narrowly amalgamate wall structure of megazooecia. 


\section{PLATE 13}

FIGURES 1-4. Leptotrypella (Pycnobasis) amphelicta Boardman, n. sp. (p. 63).

1a. Tangential view of holotype, USNM 133910, $\times 20$, showing amalgamate wall structure and strongly thickened zooecial walls in the monticule in lower right corner of figure. Wanakah shale member (as used by Buehler and Tesmer, in press) of Ludlowville shale, collection 3558a.

1b. Longitudinal view of holotype, $\times 50$, showing the leptotrypellid wall structure and thick, strongly curved cystoidal diaphragms, all compound.

2a. Longitudinal view of paratype, USNM 133911, $\times 20$, displaying crenulated walls in neanic zone, irregular zooecial grow th in high monticule, and an acanthopore extending a considerable distance beyond the zooecia. Wanakah shale member, collection $3558 \mathrm{a}$.

2 b. Longitudinal view of same specimen, $\times 50$, illustrating leptotrypellid wall structure with a thick zooecial lining.

3. Tangential section of paratype, USNM $133992, \times 50$, showing extreme zooecial wall thickening in a monticule. Kashong member (of Cooper, 1930) of Moscow shale, collection 3552.

4. Longitudinal section of paratype, USNM $133912, \times 50$, showing multiple cystoidal diaphragms. Wanakah shale member, collection $3558 \mathrm{a}$.

5. Leptotrypella (Pycnobasis) polita Boardman, u. sp. (p. 66).

5a. Longitudinal view of holotype, USNM $133913, \times 75$, showing leptotrypellid wall structure with thick zooecial linings and narrow zones of curved laminae, mural spines, and closely spaced, parallel diaphragms. Kashong member, collection 3558 .

5b. Tangential section of holotype, $\times 20$, showing integrate to narrowly amalgamate zooecial walls. Note megazooecia in monticule.

5c. Tangential section of holotype, $\times 50$. The section passes through the concentration of mural spines just distal to the zooecial bend. Note integrate wall structure. 
GEOLOGICAL SURVEY

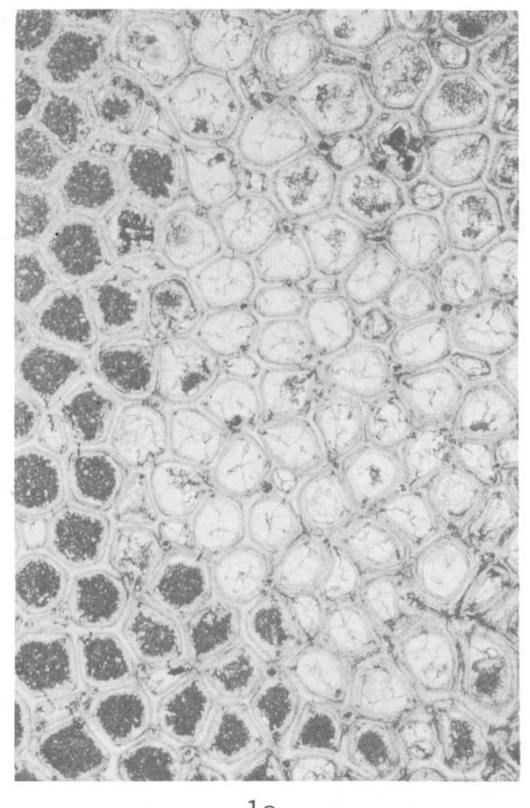

$1 \mathrm{a}$

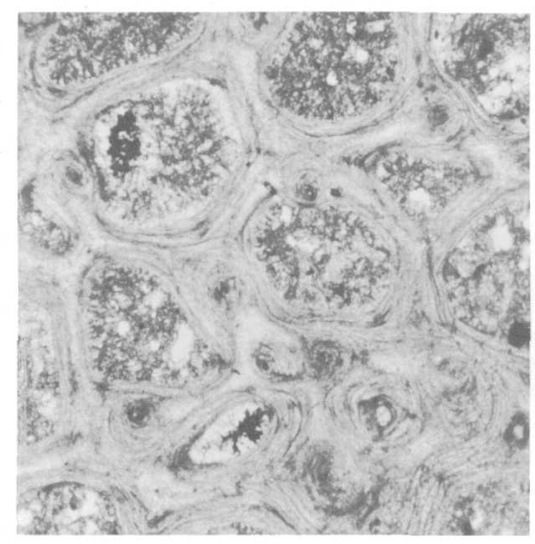

3

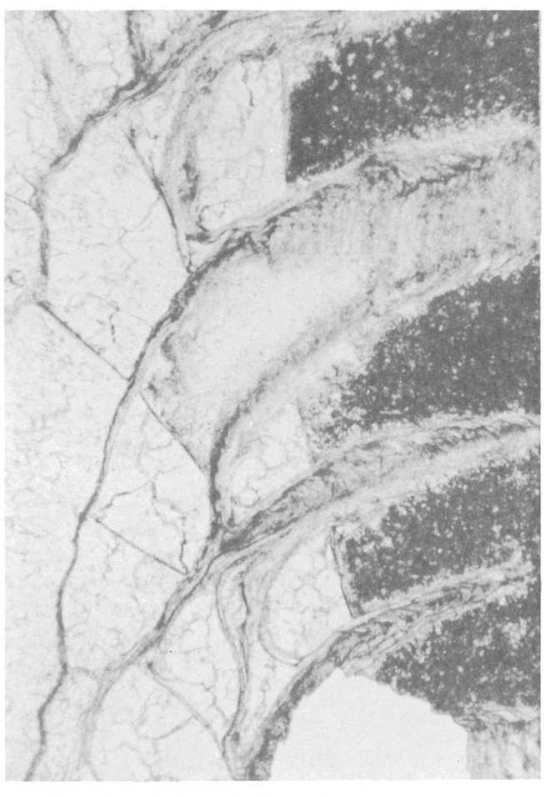

$1 b$

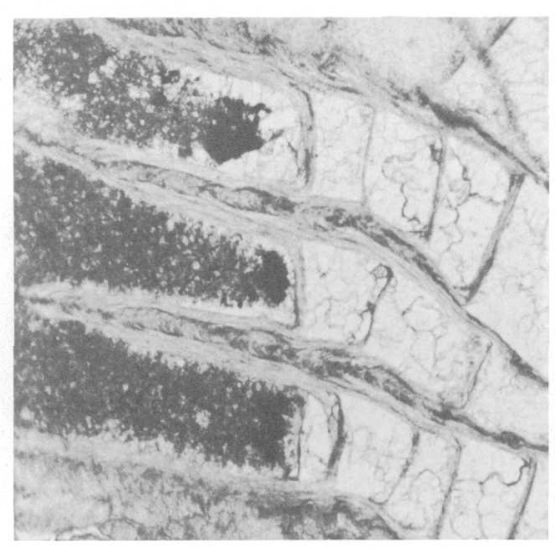

$2 b$

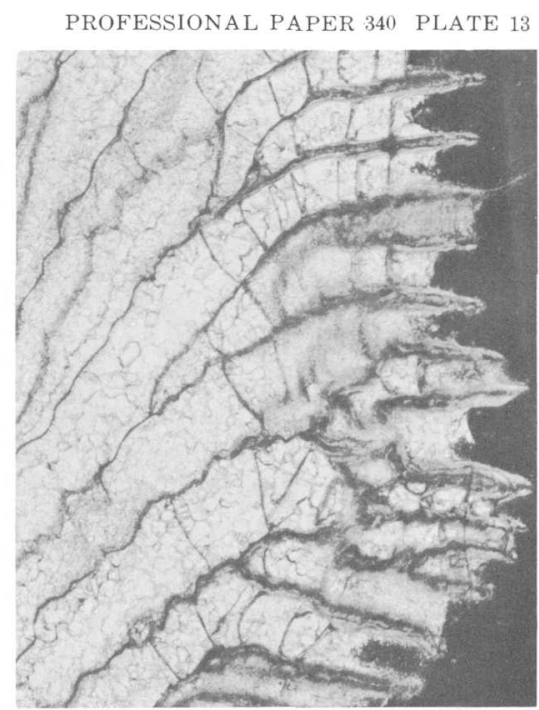

$2 a$

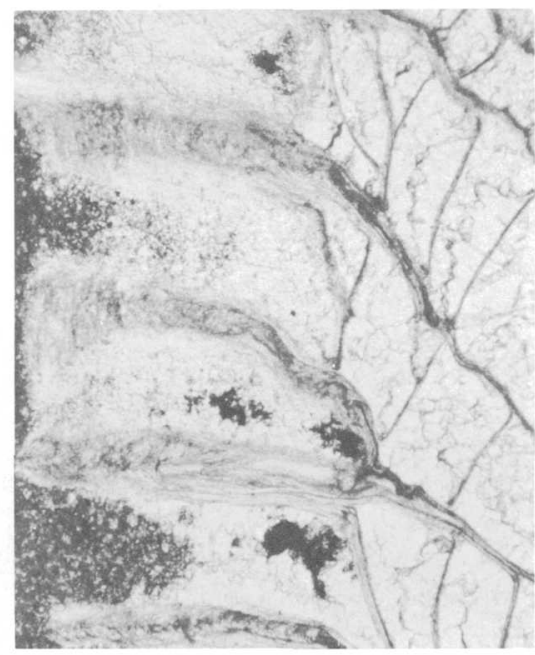

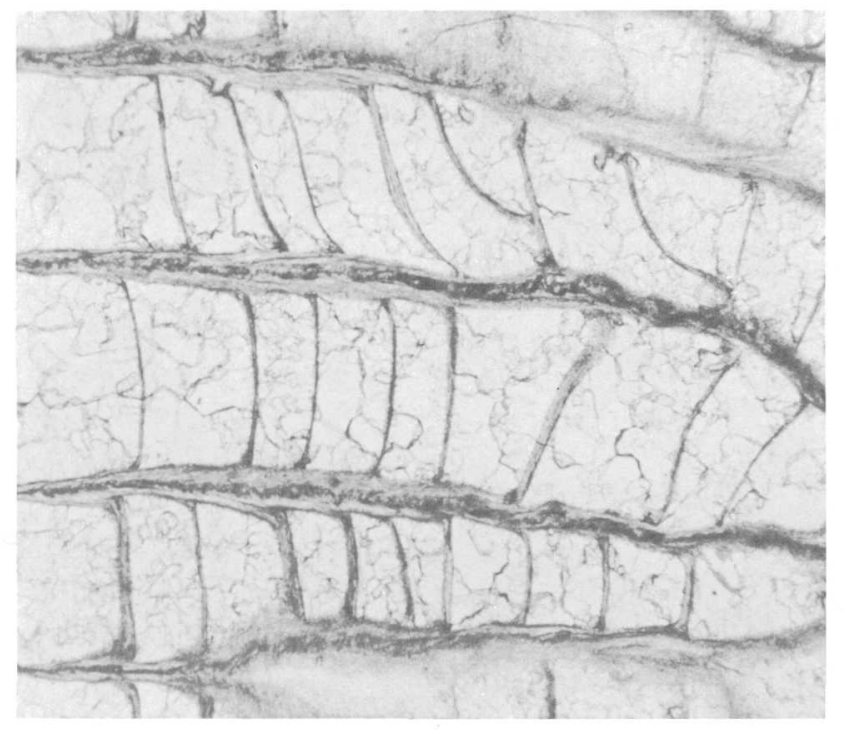

$5 a$

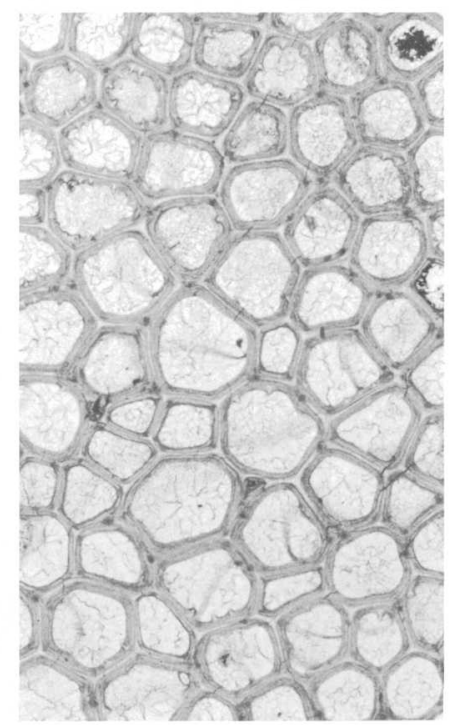

$5 b$

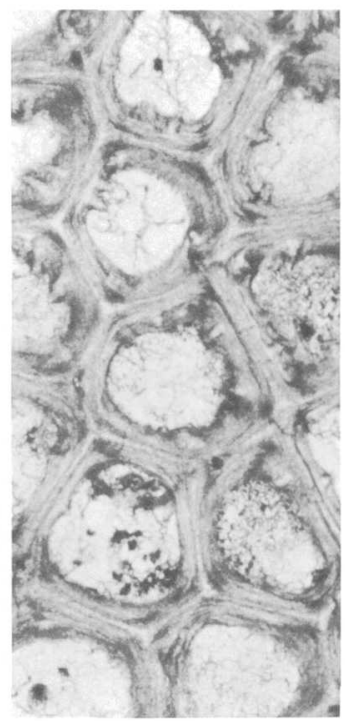

$5 c$

LEPTOTRYPELLA (PYCNOBASIS) AMPHELICTA, N. SP., AND L. (P.) POLITA, N.SP. 


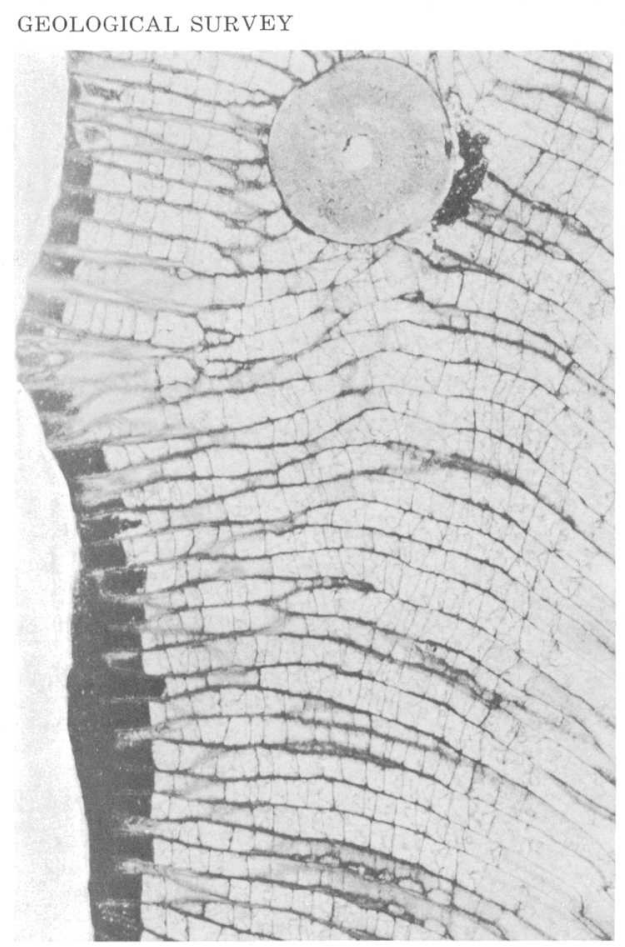

$1 \mathrm{a}$

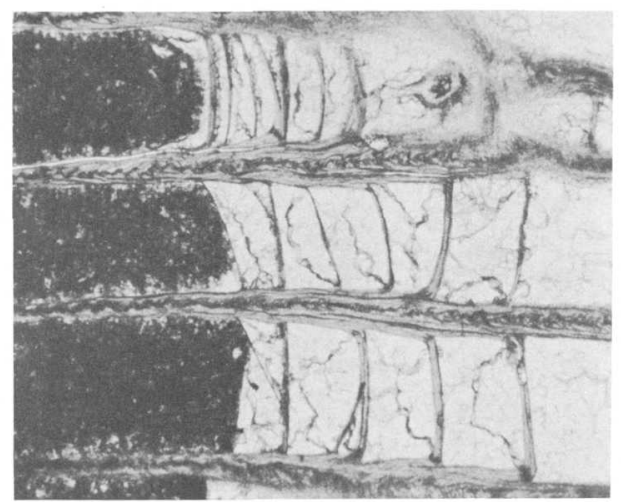

$1 \mathrm{c}$

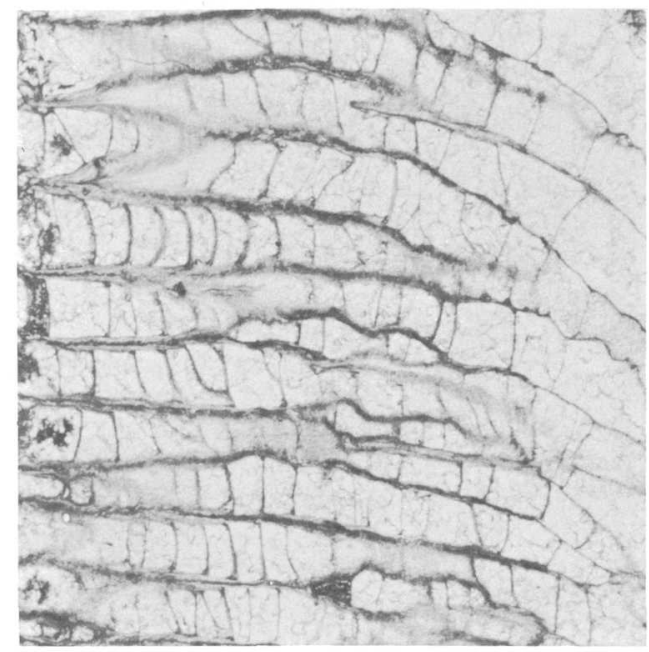

$3 a$

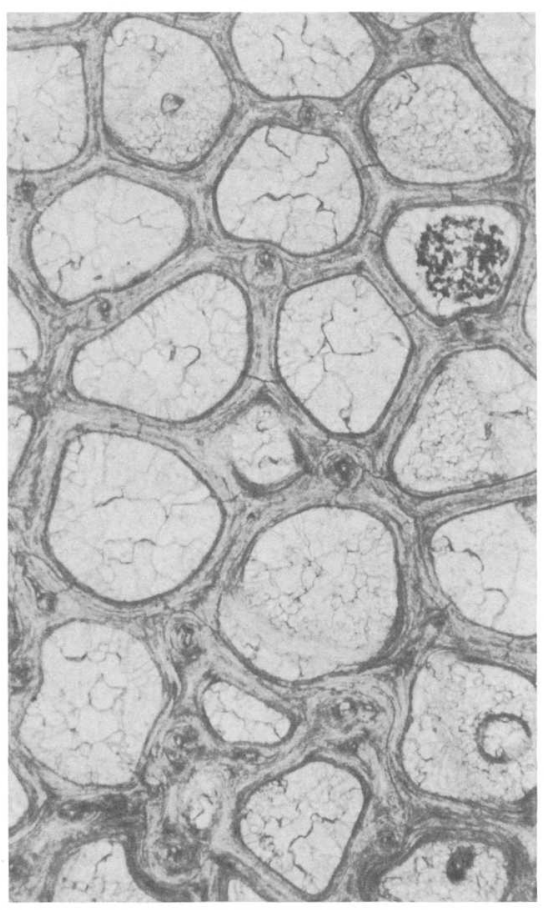

$1 b$

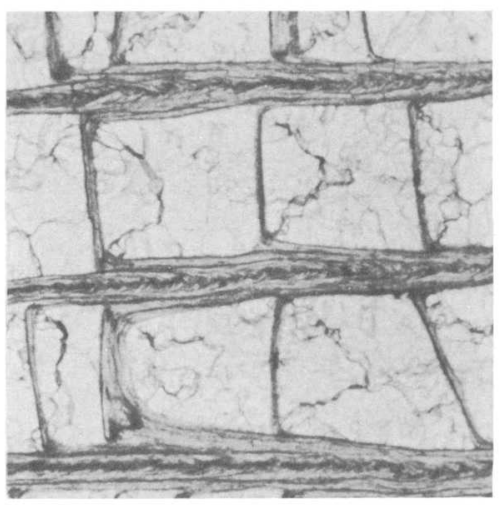

$1 \mathrm{~d}$

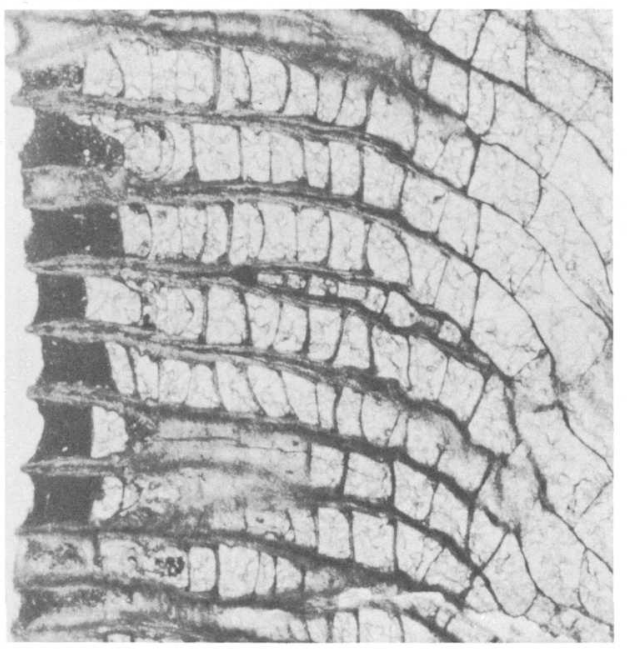

$3 b$

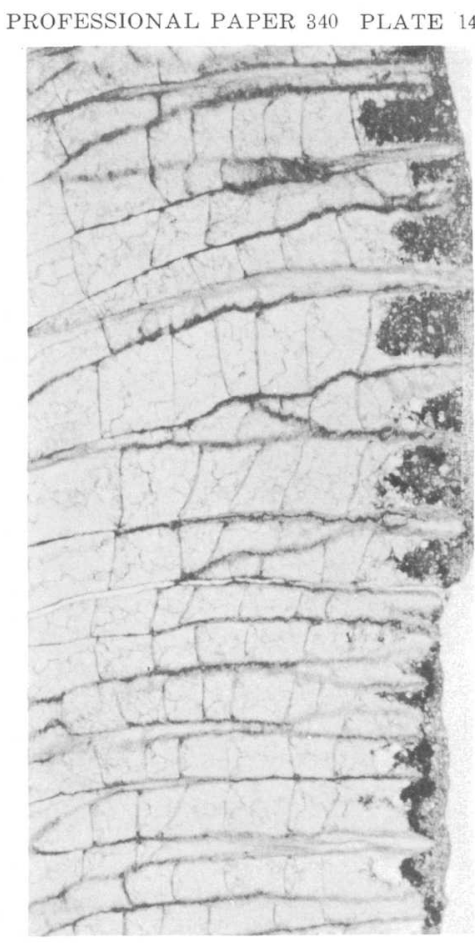

$2 a$
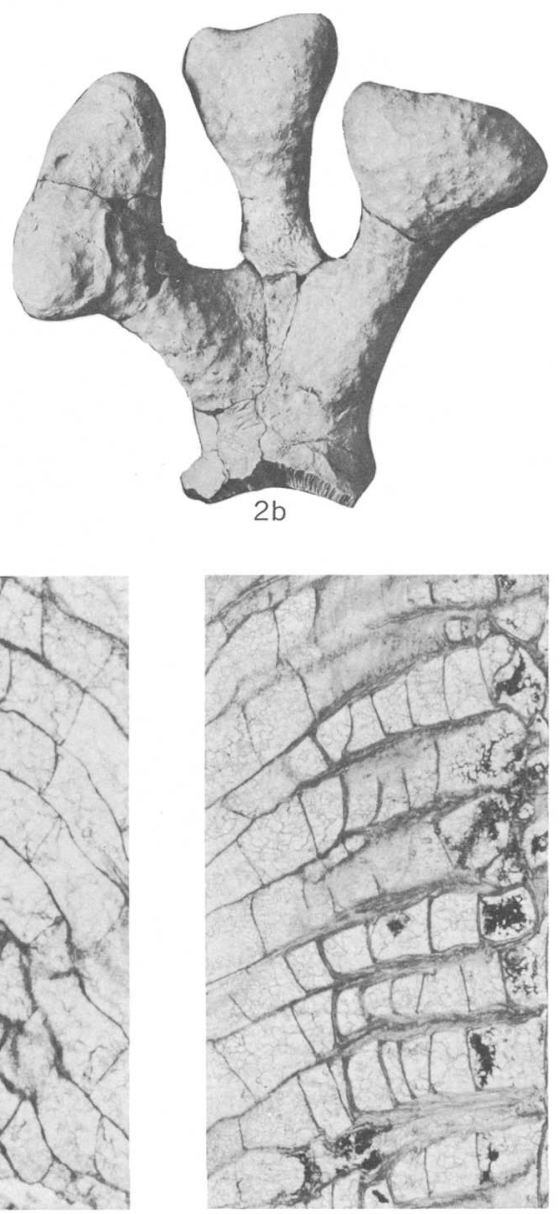

$3 c$

LEPTOTRYPELLA (PYCNOBASIS) TUBERATA, N. SP., AND L. (P.) POLITA, N. SP. 


\section{PLATE 14}

FirURes 1, 2. Leptotrypella (Pycnobasis) tuberata Boardman, n. sp. (p. 65).

1a. Longitudinal view of holotype, USNM $133914, \times 10$, showing raised monticule with strongly thickened zooecial walls. Note crinoid columnal and the zooecial growth around it. King Ferry shale member (of Cooper, 1930) of Ludlowville shale, collection 3582.

1b. Tangential section of holotype, $\times 50$, showing generally integrate wall structure, also the greatly enlarged acanthopores and thickened walls of the zooecia of the monticule in the bottom half of the figure.

1c. Longitudinal section of holotype, $\times 50$, showing zooecia on the margin of a monticule that contain closely and irregularly spaced diaphragms, several of them compound.

1d. Longitudinal section of holotype, $\times 75$, showing a well marked zooecial boundary of abutting laminae and a zooecial lining determined primarily by the thickness of adjacent diaphragms.

2a. Longitudinal view of paratype, USNM 133915, $\ 20$, showing growth stage of $6-7$ diaphragms. Deep Run member (of Cooper, 1930) of Ludlowville shale, collection 3555a.

$2 \mathrm{~b}$. External view of nearly complete zoarium of same paratype, $\times 1 / 2$, showing subramose growth habit, the remains of a basal expansion, and high monticules on the surface.

3. Leptotrypella (Pycnobasis) polita Boardman, n. sp. (p. 66).

3a. Longitudinal view of holotype, USNM 133913, $\times 20$, showing growth stage of 11-16 diaphragms. Kashong member (of Cooper, 1930) of Moscow shale, collection 3558.

3b. Longitudinal view of holotype, $\times 20$, showing growth stage of $12-14$ diaphragms.

3c. Longitudinal view of holotype, $\times 20$, showing growth stage of 5-7 diaphragms. 


\section{PLATE 15}

Figures 1, 2. Polycylindricus asphinctus Boardman, n. sp. (p. 68).

1a. Longitudinal section of holotype, USNM 133916, $\times 50$, illustrating the leptotrypellid wall structure that lacks zooecial lining. Note large laminated acanthopore at top of figure. Wanakah shale member (as used by Buehler and Tesmer, in press) of Ludlowville shale, collection 3524.

1b. Longitudinal section of holotype, $\times 20$. Note overgrowth with reversed crientation of zooecia. The zooecia in upper right corner of figure form the base of a secondary branch projecting at right angles to the primary branch.

1c. Longitudinal section of holotype, $\times 20$, showing irregularly crenulated walls of the neanic zone and the budding of relatively short secondary zooecia from long primary zooecia.

1d. Tangential view of holotype, $\times 20$, showing thick, broadly amalgamate walls and the large acanthopores.

1e. Tangential view of holotype, $\times 50$, illustrating the laminated acanthopores.

2. Transverse section of paratype, USNM 133917, $\times 10$, showing the progressive flattening of the zooecia from the center of the branch outward in the neanic zone. Wanakah shale member, collection 3524 .

3, 4. Leptotrypella (Pycnobasis) pachyphragma Boardman, n. sp. (p. 64).

3a. Longitudinal section of holotype, USNM $133918, \times 100$, displays irregularly shaped mural spines, thick diaphragms and zooecial lining, and relatively narrow zone of curved laminae. Tichenor limestone member of Ludlowville shale, collection 3586.

3 b. Tengential section of holotype, $\times 50$. Section passes through the concentration of mural spines. Mural lacunae give speckled appearance to zone of curved laminae.

3c. Tangential section of holotype, $\times 20$. Note integrate appearance of megazooecial walls in monticule at lower right of figure.

3d. Longitudinal section of holotype, $\times 20$, showing regularly tabulated mesopores and generally thick diaphragms.

4. Longitudinal section of paratype USNM $133919, \times 75$, showing thick compound diaphragms, thick zooecial linings, and narrow zones of curved laminae. Wanakah shale member, collection 3555 . 
GEOLOGICAL SURVEY

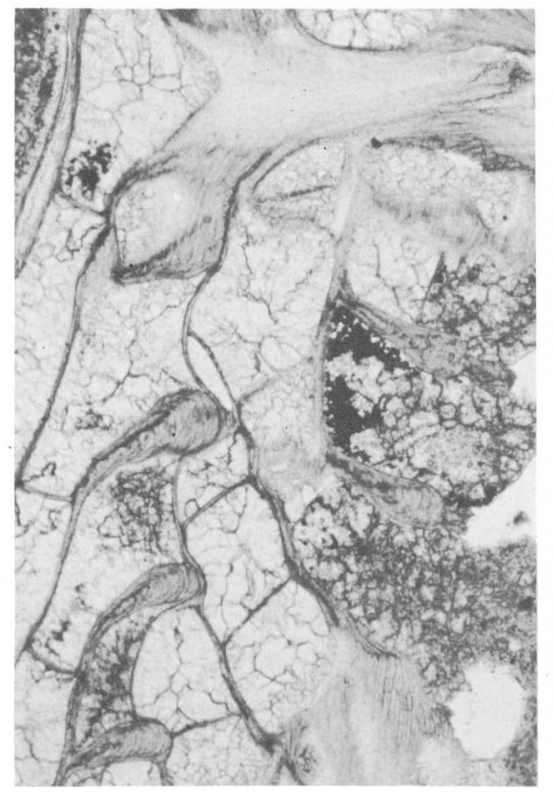

$1 \mathrm{a}$

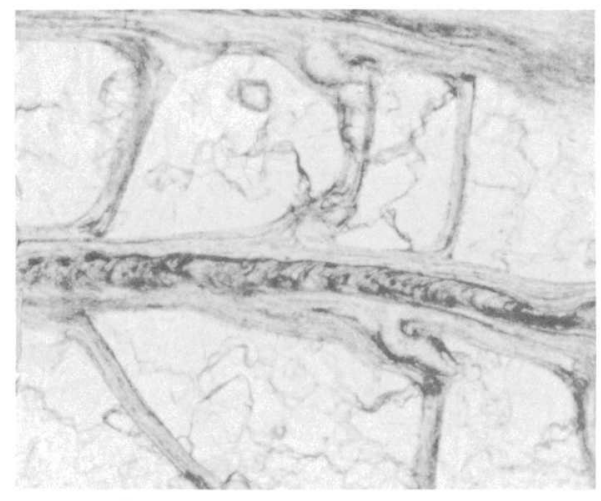

$3 a$

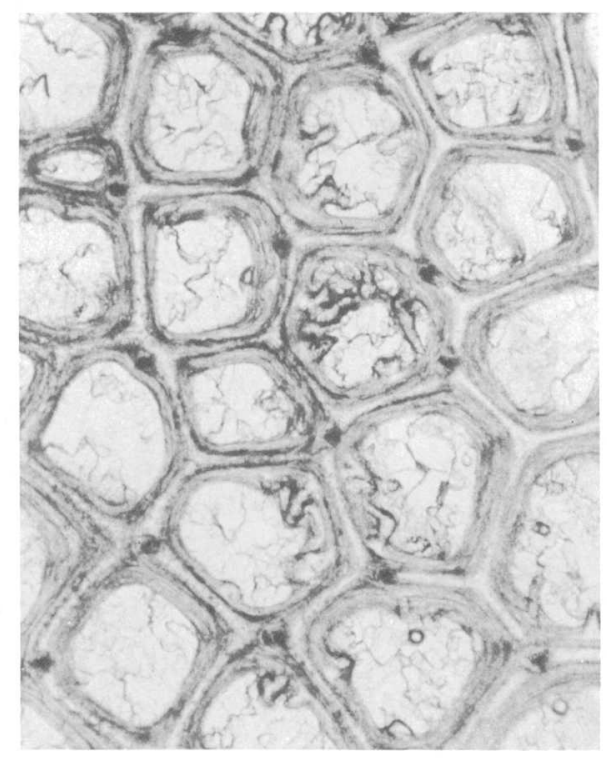

$3 b$

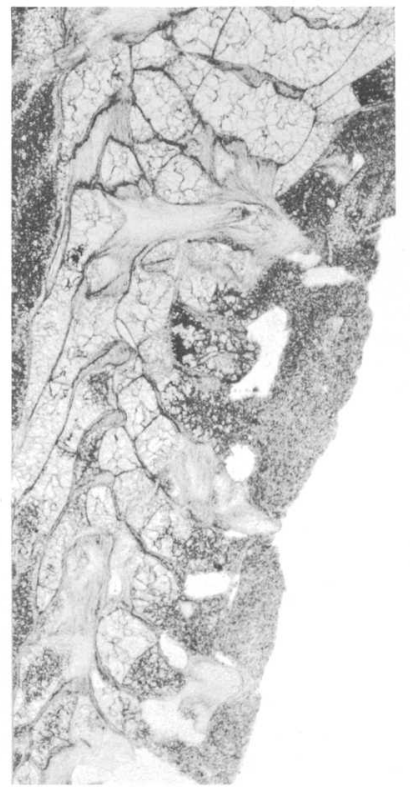

$1 b$

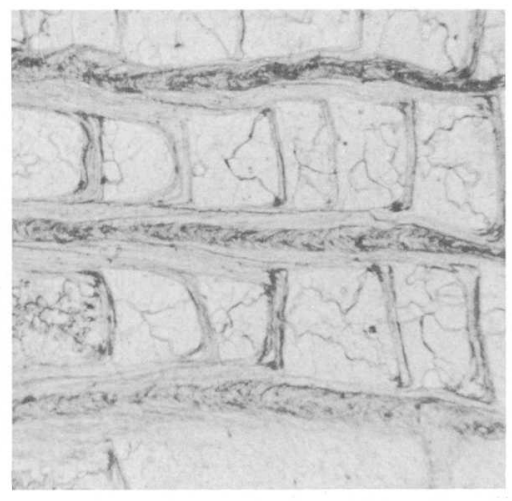

4

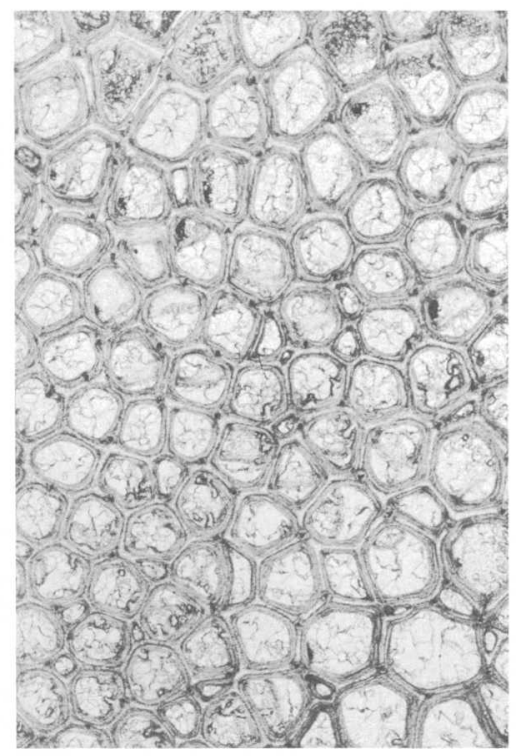

$3 c$

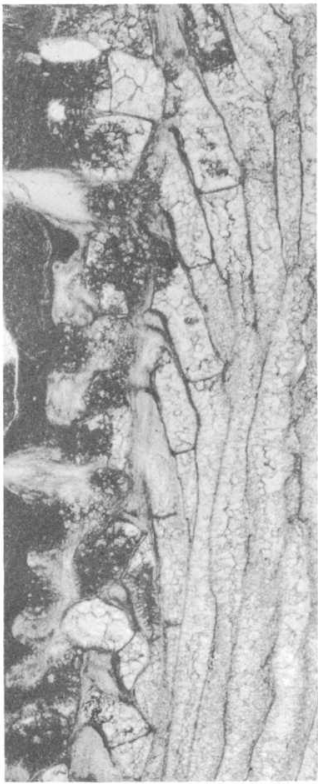

$1 \mathrm{c}$

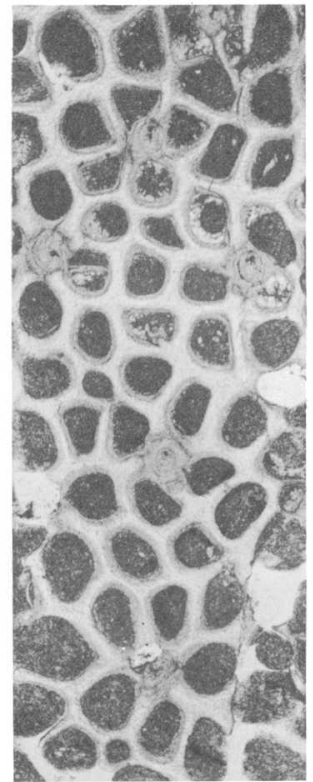

$1 d$

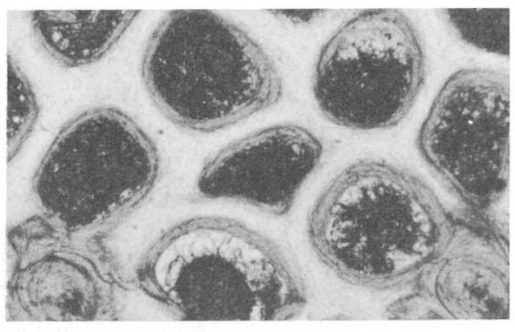

$1 e$

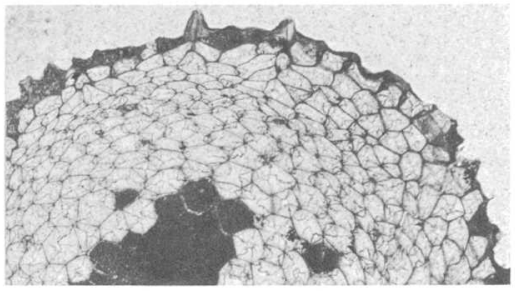

2

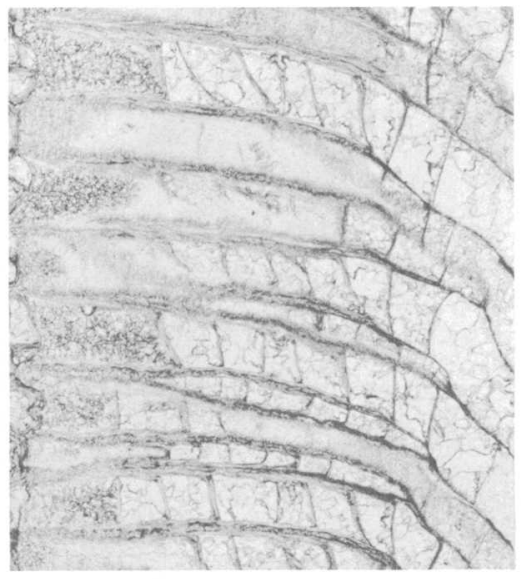

$3 d$

POLYCYLINDRICUS ASPHINCTUS, N. SP. AND LEPTOTRYPELLA

(PYCNOBASIS) PACHYPHRAGMA, N. SP. 


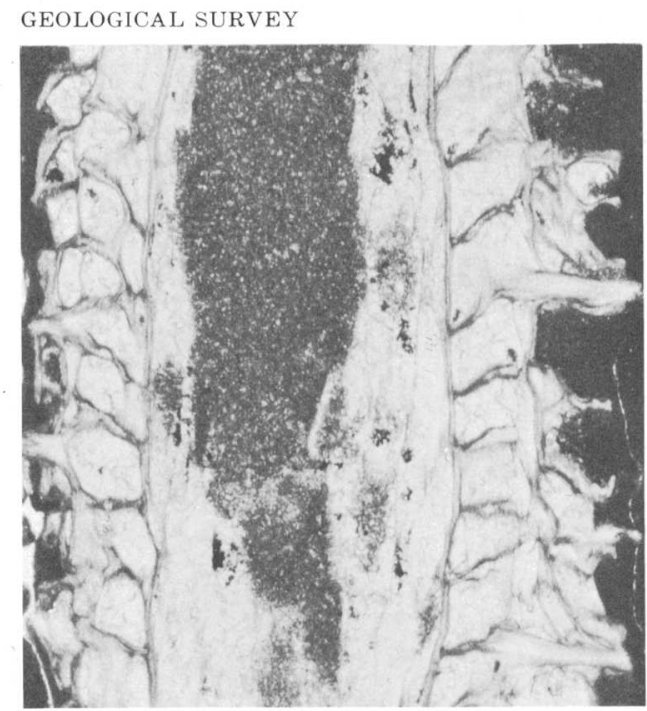

$1 \mathrm{a}$

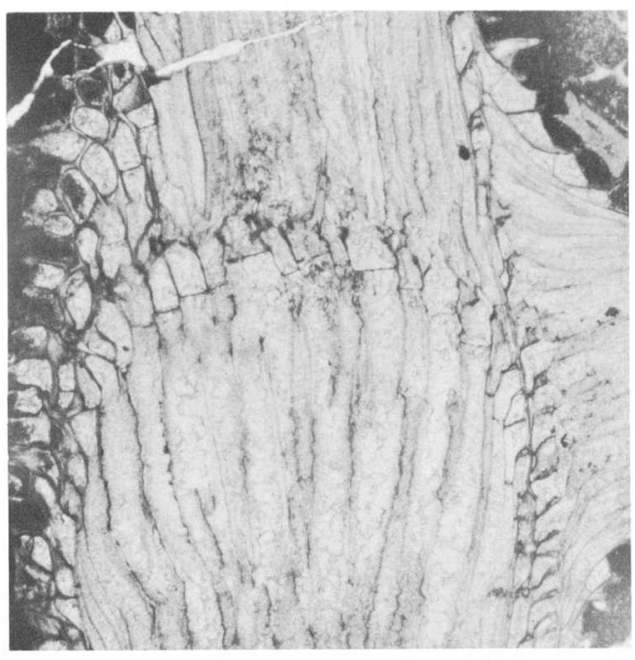

2

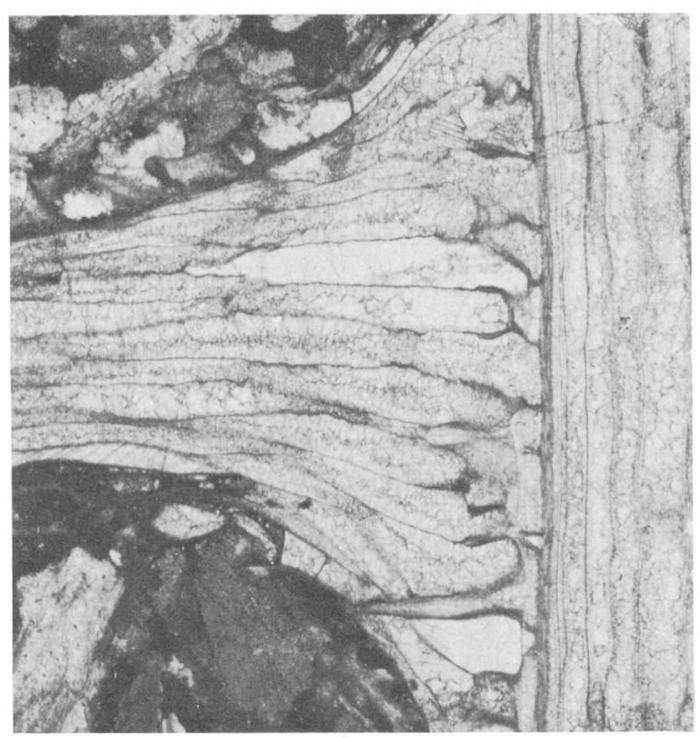

4

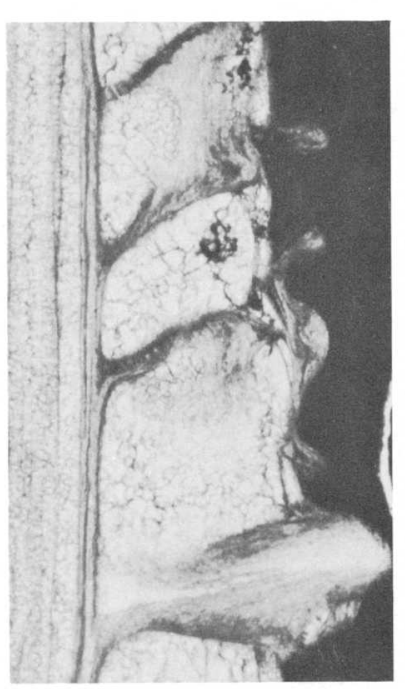

$1 b$

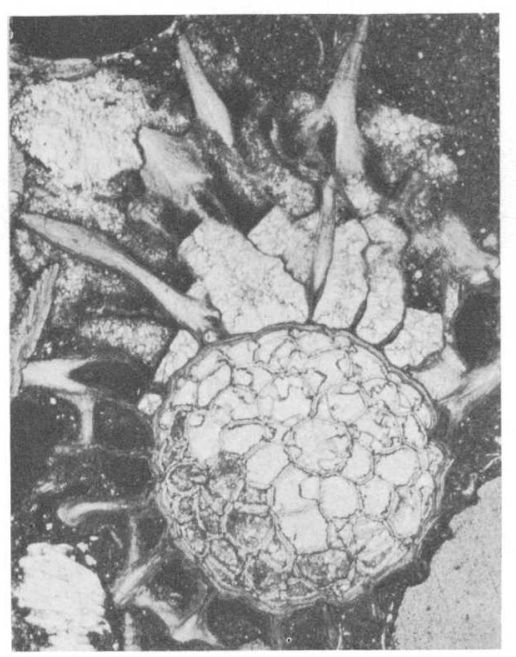

3

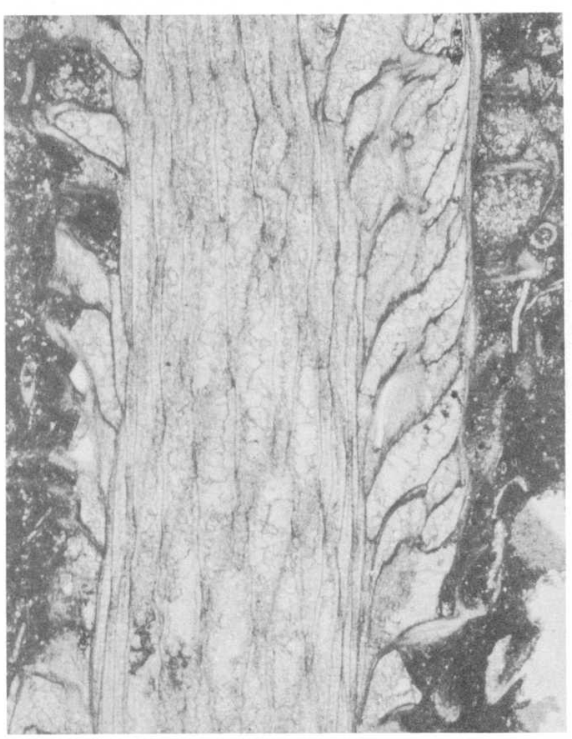

5
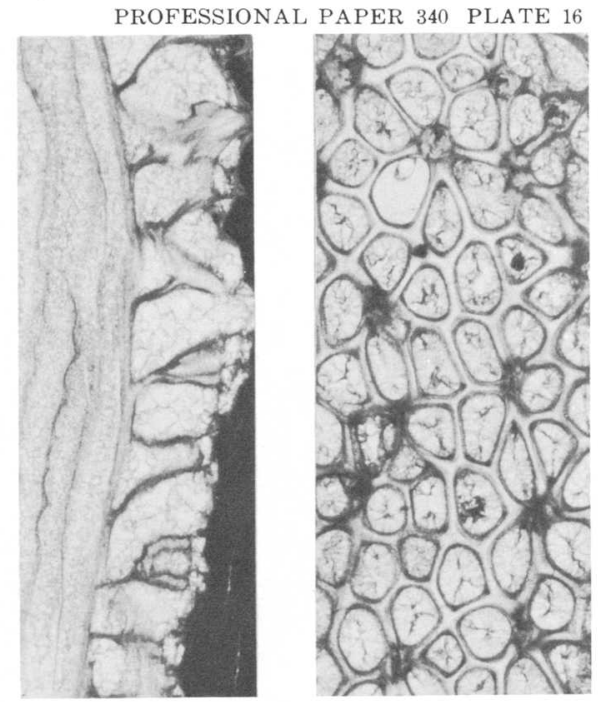

$1 \mathrm{c}$

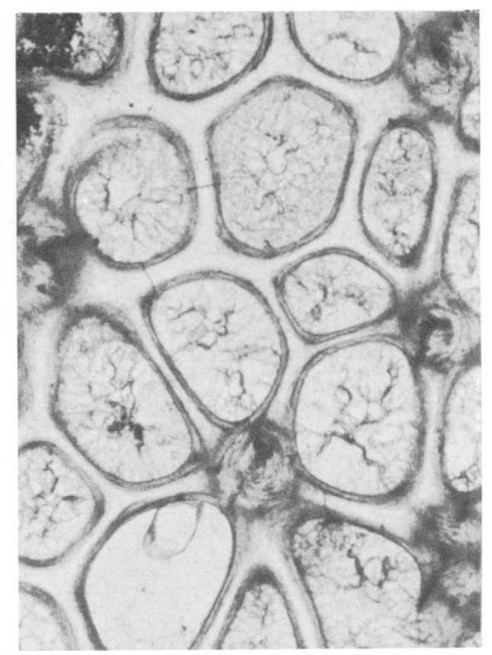

$1 \mathrm{e}$

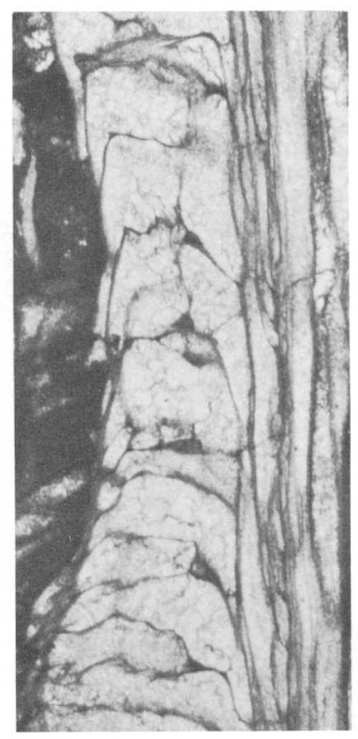

6

POL YCYLINDRICUS CLAUSUS, N. SP. 


\section{PI.ATE 16}

Figures 1-6. Polycylindricus clausus Boardman, n. sp. (p. 68).

1a. Longitudinal section of small branch of holotype, USNM $133920, \times 20$, showing normal conspecific overgrowth separated from the supporting branch by a basal lamination. Windom member of Moscow shale, collection 3553.

1b. Longitudinal section of holotype, $\times 50$. Note layered structure of cylinder wall and continuation of individual layers with the zooecial walls of the ephebic zone.

1c. Longitudinal section of holotype, $\times 20$, showing a mesopore, its length contained within the thick-walled part of the ephebic zone.

1d. Tangential section of holotype, $\times 20$, showing petaloid grouping of zooecia around the large acanthopores.

1e. Tangential section of holotype, $\times 50$, showing the laminated acanthopores and broadly amaigamate zooecial walls.

2. Longitudinal section of paratype, USNM 13:3921, $\times 10$. Shows abandoned growing tip that apparently underwent little resorption, note large acanthopore in center of branch at the tip. Section also shows an incrusting overgrow th that gives rise to a secondary branch. Windom member, collection 3553 .

3. Transverse section of paratype, USNM $133922, \times 20$, illustrating the progressive flattening of the zooecia from the center of the branch outward to the cylinder, fluting of the thickened wall of the cylinder, and the length of the acanthopores. Centerfield limestone member of Ludlowville shale, collection 3571.

4. Longitudinal section of paratype, USNM 133923, $\times 20$. Illustrates the method of branching that produces discordantly small, secondary branches, perpendicular to the supporting stem. Note long acanthopore spine of the primary ephebic zone extending well into secondary branch. Centerfield limestone member, collection 3571 .

5. Longitudinal section of paratype, USNM $133924, \times 20$, illustrating secondary growth without the formation of a basal lamination, and subsequent formation of a second cylinder and ephebic zone. Centerfield limestone member, collection 3571 .

6. Longitudinal section of paratype, USNM 133925, $\times 20$, showing elongated, thin-walled zooecial development distal to the thickened cylinder. Note also the secondary growth with reversed zooecial orientation. Centerfield limestone member, collection 3571 . 


\section{PLATE 17}

Figures 1-5. Atactotoechus acritus Boardman, n. sp. (p. 72).

1a. Tangential section of holotype, USNM 133926, $\times 50$, showing integrate wall structure with light colored zooecial boundaries. Centerfield limestone member of Ludlowville shale, collection 3561 .

1b. Longitudinal section of holotype, $\times 20$, showing growth stage of 5-7 diaphragms.

1c. Tangential section of holotype, $\times 20$, showing monticule in lower left of figure indicated by slightly larger zooecia with thickened walls.

2. Longitudinal section of paratype, USNM $133927, \times 20$. The part of section displaying zooecia closely approaching $A$. cartus cartus in general appearance. Ledyard member, collection 3541.

3. Longitudinal section of paratype, USNM 133928, $\times 20$, illustrating erratic and non-parailel cystoidal diaphragms. Centerfield limestone member, collection 3571 .

4. Longitudinal section of paratype, USNM $133929, \times 5$, showing the zoarium incrusting a gastropod and also developing a ramose growth habit. Centerfield member, USNM collection 160c, Fellows Falls, Tully quadrangle, New York.

5. Longitudinal section of paratype, USNM $133930, \times 50$, displaying a cystiphragm and atactotoechid wall structure with dark serrated zooecial boundary. Centerfield limestone member, collection 3571 .

6. Atactotoechus parallelus Boardman, n. sp. (p. 74).

6a. Longitudinal section of holotype, USNM 133931, $\times 100$, illustrating atactotoechid wall structure including a dark zooecial boundary and an uncommon and very thin zooecial lining that is discontinuous along the zooecium. King Ferry shale member (of Cooper, 1930) of Ludlowville shale, collection 3564.

6b. Longitudinal section of holotype, $\times 15$, showing growth stage of $25-28$ diaphragms in ephebic zone.

6c. Longitudinal section of holotype, $\times 20$, showing growth stage of 10-12 diaphragms. Note strong curvature of diaphragms of monticular zooecia and parallelism of diaphragms throughout.

$6 \mathrm{~d}$. Tangential section of holotype, $\times 50$, showing integrate appearance and light zooecial boundaries. 


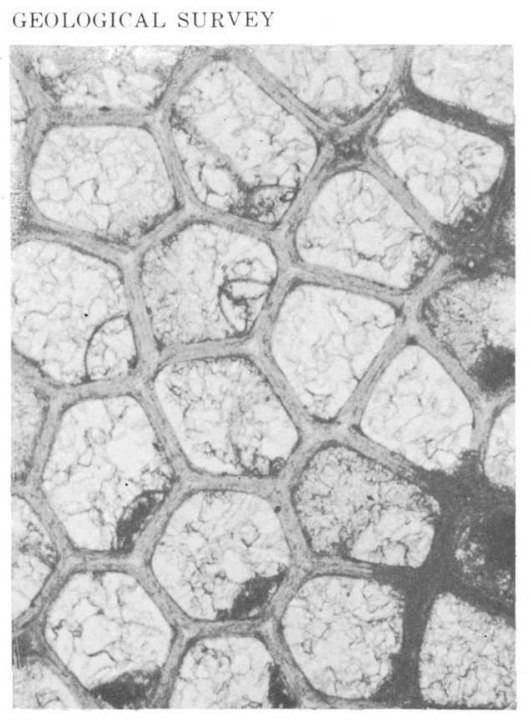

$1 a$
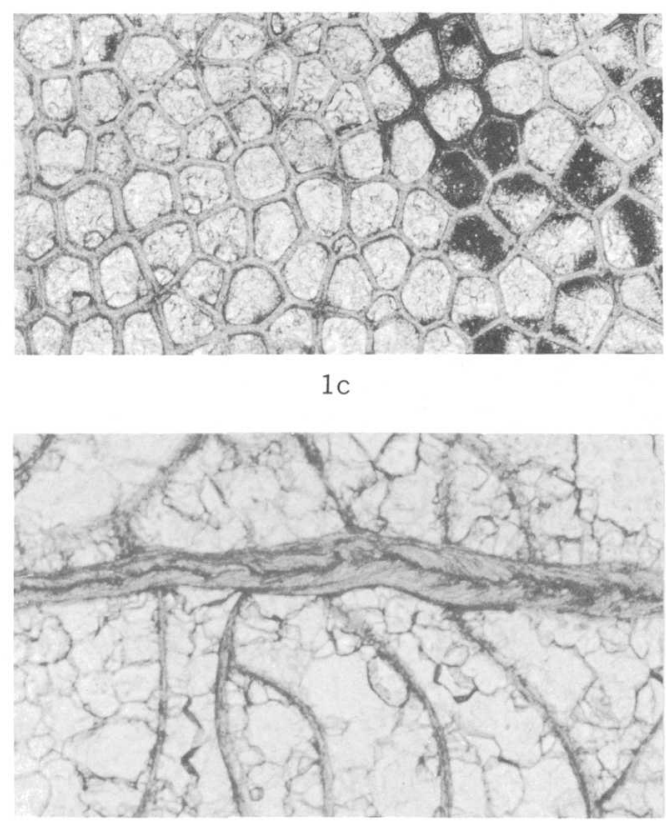

$6 a$

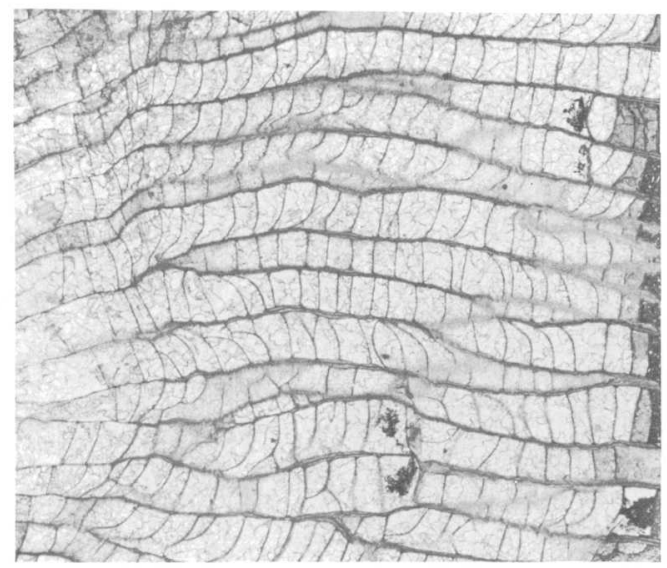

$6 b$

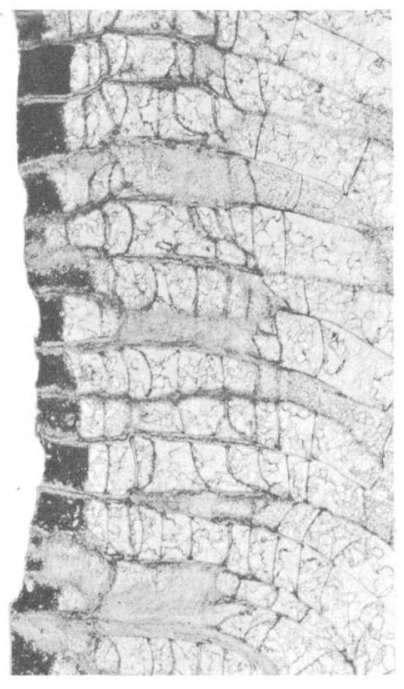

$1 \mathrm{~b}$

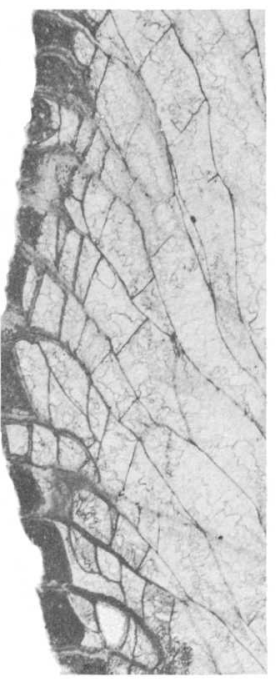

2

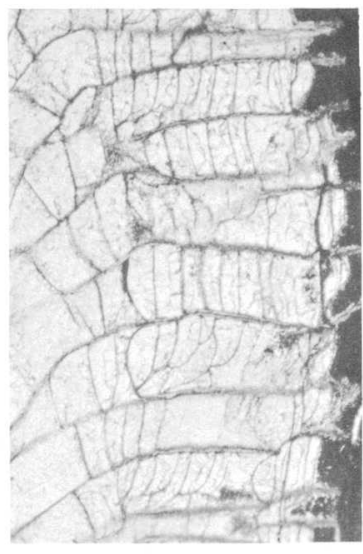

3

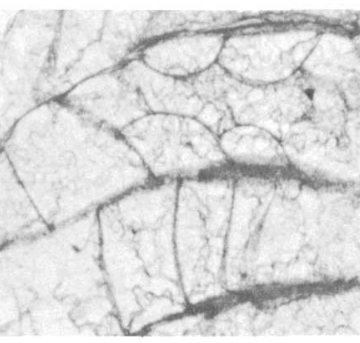

5

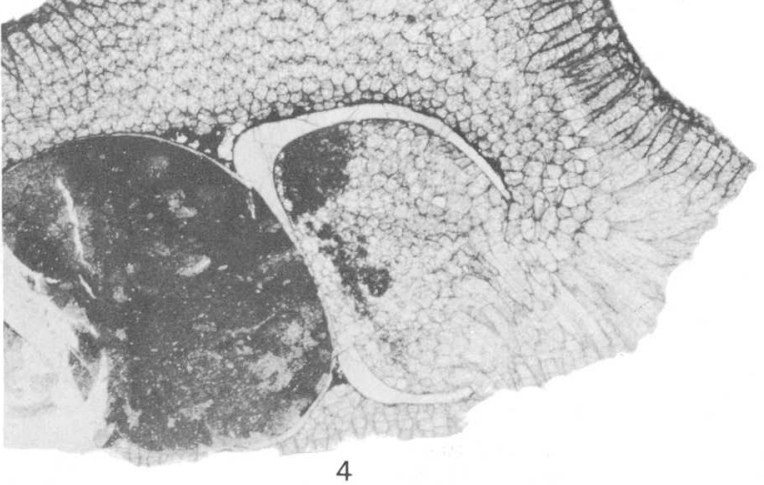

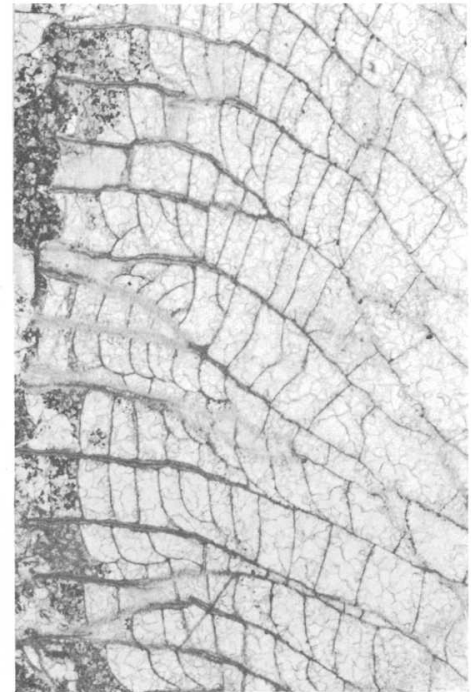

$6 c$

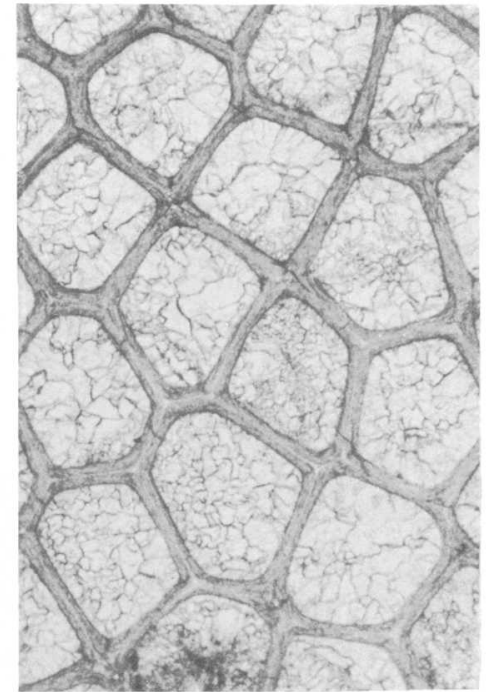

$6 d$

ATACTOTOECHUS ACRITUS, N. SP., AND ATACTOTOECHUS PARALLELUS, N. SP. 
GEOLOGICAL SURVEY

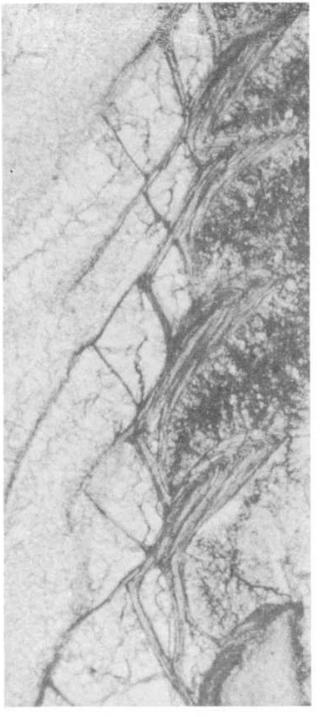

1

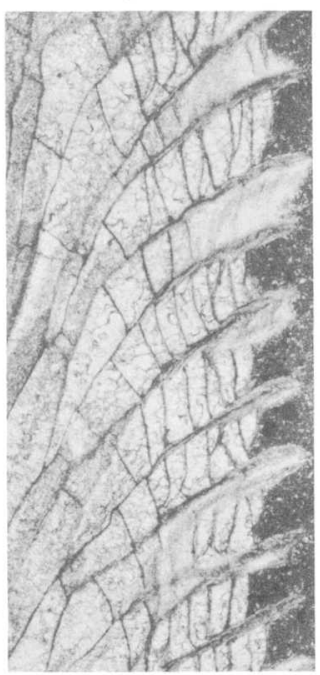

$4 a$

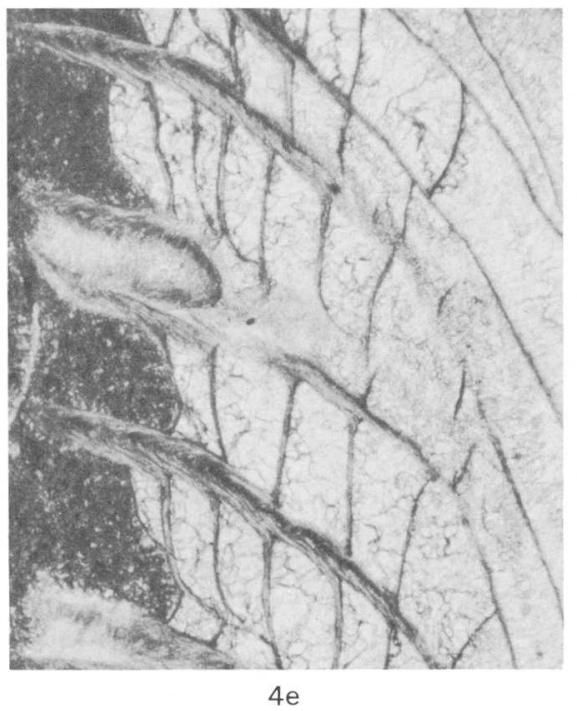

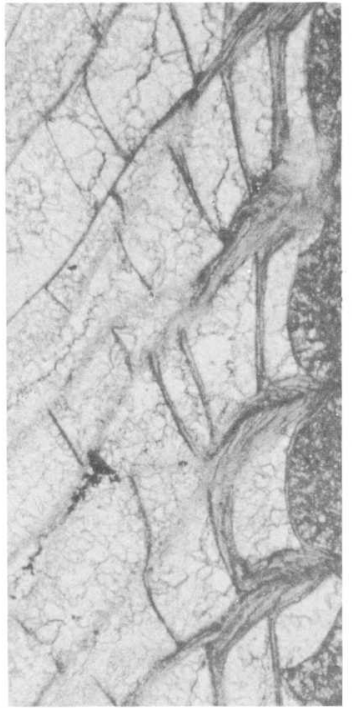

2

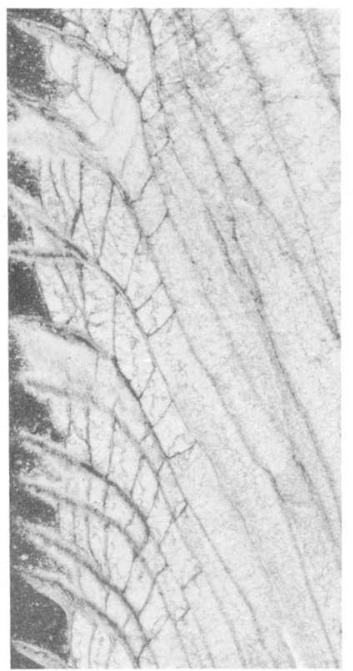

4

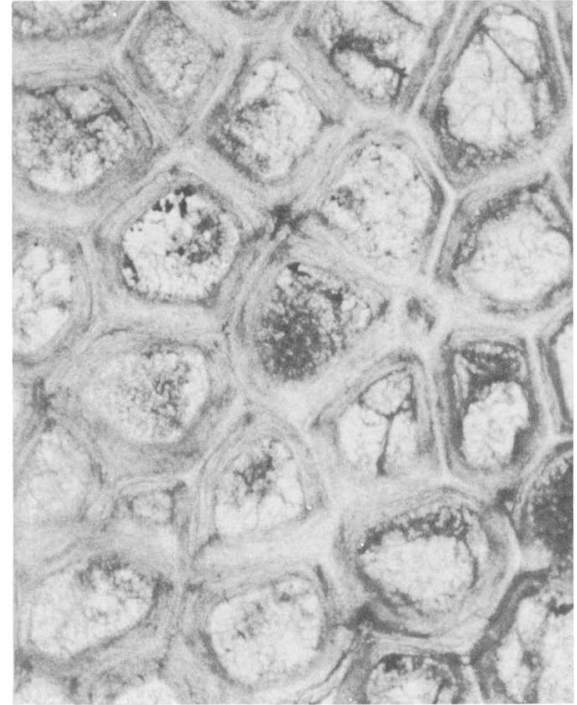

$3 a$

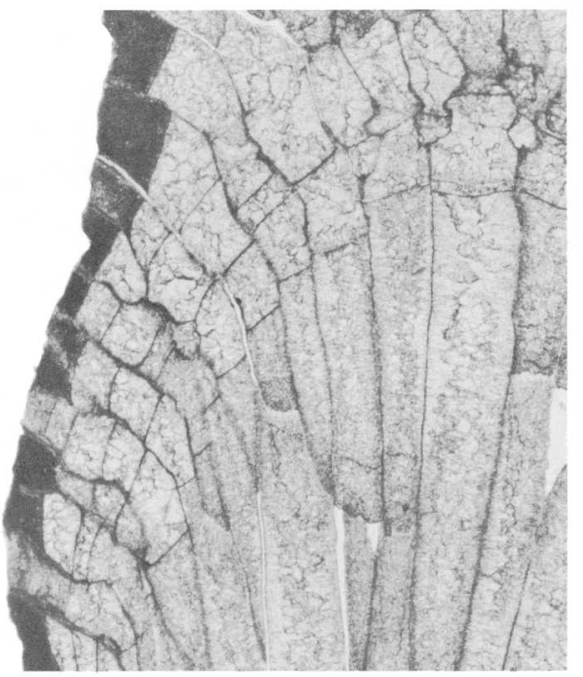

$4 c$

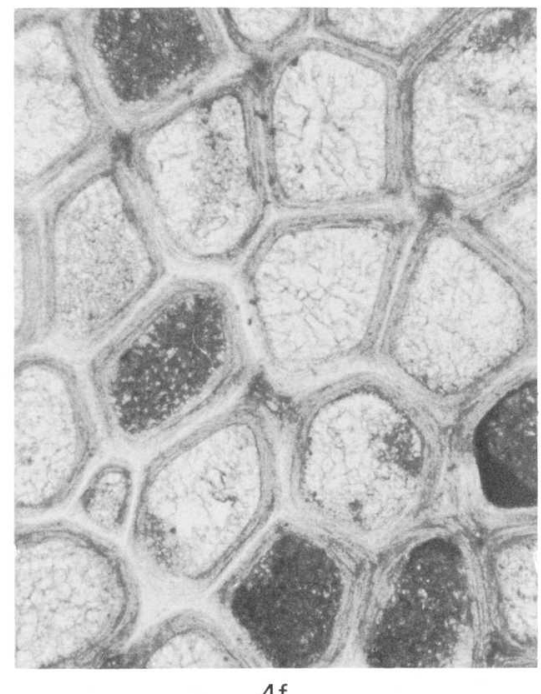

$4 f$

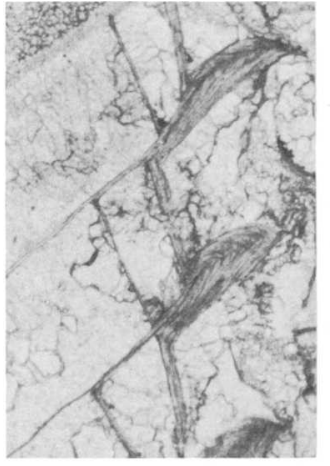

$3 b$

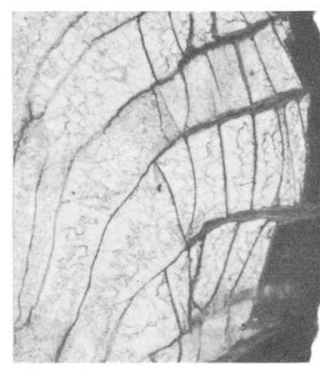

2.5.

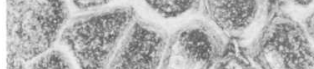

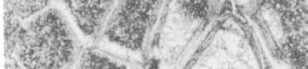

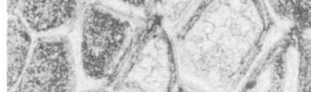

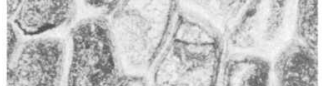

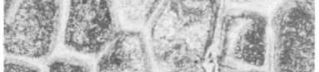
6. 14. Nis fing 4d

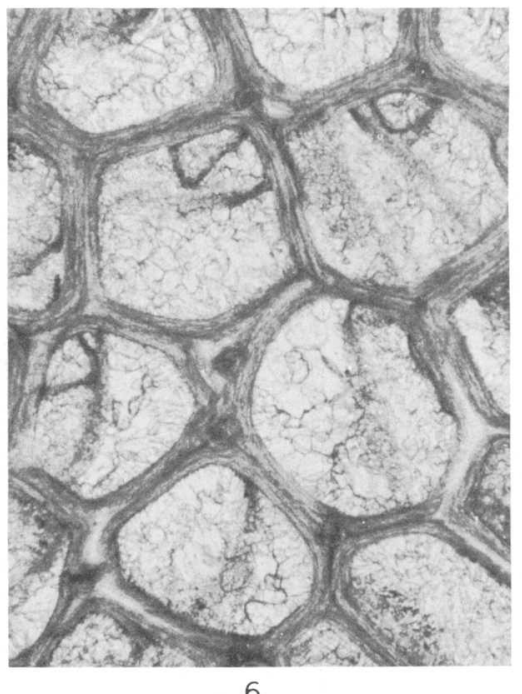

6

ATACTOTOECHUS CARTUS PILATUS. N. SUBSP., AND ATACTOTOECHUS CARTUS CARTUS, N. SUBSP. 


\section{PLATE 18}

Figures 1-3. Atactotoechus carlus pilatus Boardman n. subsp. (p. 74).

1. Longitudinal section of paratype, USNM 133932, $\times 50$, showing atactotoechid wall structure with zooecial boundaries marked by intersection of laminae. Note thick walls and diaphragms. Kashong member (of Cooper, 1930) of Moscow shale, collection 3552.

2. Longitudinal section of paratype, USNM $133933, \times 50$, showing well marked zooecial boundaries. Note that the thickness of the zooecial walls in the ephebic zone is largely controlled by the thickness of the contributing diaphragms. Kashong member, collection 3552.

3a. Tangential section of holotype, USNM $133934, \times 50$, displaying integrate wall structure. Kashong member, collection 3552 .

3b. Longitudinal section of holotype, $\times 50$, showing thick walls and diaphragms.

4-6. Atactotoechus cartus cartus Boardman, n. subsp. (p. 73).

4a. Longitudinal section of holotype, USNM 133935, $\times 20$, showing growth stage of $8-10$ diaphragms. Portland Point member (of Cooper, 1930) of Moscow shale, collection 3551.

4b. Longitudinal section of holotype, $\times 20$, showing growth stage of 7-9 diaphragms. Note strongly curved cystoidal diaphragms concentrated in the megazooecia in upper half of figure.

$4 \mathrm{c}$. Longitudinal section of holotype, $\times 20$, displaying an abandoned growing tip. Note a growth stage of $3-4$ diaphragms below the tip, and 1 diaphragm beyond the tip.

4d. Tangential section of holotype, $\times 20$, showing megazooecia of a monticule.

4e. Longitudinal section of holotype, $\times 50$, displaying atactotoechid wall structure with a marked zooecial boundary. The zooecia are in a monticule; note repeated cystoidal diaphragms.

4f. Tangential section of holotype, $\times 50$, showing integrate wall structure and very small acanthopores.

5. Longitudinal section of paratype, USNM $133937, \times 20$, showing megazooecia containing planar and parallel diaphragms. Portland Point member, collection 3551.

6. Tangential section of paratype, USNM $133939, \times 50$. Note only slightly enlarged acanthopores of the megazooecia as compared with the intermonticular zooecia in fig. 4f. Loops in the zooecial voids are curved diaphragms as they appear in tangential section. Portland Point member, collection 3551. 


\section{PLATE 19}

Fir.unes 1-6. Atactotoechus fruticosus (Hall) (p. 76).

1a. Tangential section of lectotype, New York State Museum $6182, \times 50$. Note light zooecial boundaries of integrate walls and the scarcity of acanthopores, Hamilton group, Canandaigua Lake N.Y.

1b. Longitudinal section of lectotype, $\times 50$, showing atactotoechid structure of thick zooecial walls. Note zooecial boundaries are sharply defined and dark in longitudinal sections.

2a. Longitudinal section of identified specimen, USNM 133940, $\times 20$, showing branching part of zoarium. Windom member of Moscow shale, collection 3553.

2 b. Longitudinal section from same zoarium, $\times 20$, showing incrusting part of zoarium displaying a growth stage of 8-10 diaphragms. The distally located branching part shown in figure 2 a has a growth stage of 5-6 diaphragms.

3a. Tangential section of identified specimen, USNM 133941, $\times 20$, showing a monticule with thicker walled megazooecia and several mesopores. Zooecial walls are integrate, a light line marking the zooecial boundaries. Windom member, collection 3559.

3b. Longitudinal section of same specimen, $\times 20$, showing a growth stage of 23-26 diaphragms.

4. Longitudinal section of identified specimen, USNM $133942, \times 20$, showing growth stage of 4-5 diaphragms and an abandoned growing tip that has undergone little or no resorption. Windom member, collection 3553 .

5. Longitudinal section of identified specimen, USNM 133943, $\times 20$, showing growth stage of 11-13 diaphragms. Note irregular growth of zooecia in monticule at bottom of figure. Windom member, collection 3562.

6. Longitudinal section of identified specimen, USNM $133944, \times 20$, showing a growth stage of 6-9 diaphragms. The incrusting fistuliporoid bryozoan at the right might have caused the early death of the zooecia in this part of the zoarium. Windom member, collection 3579 


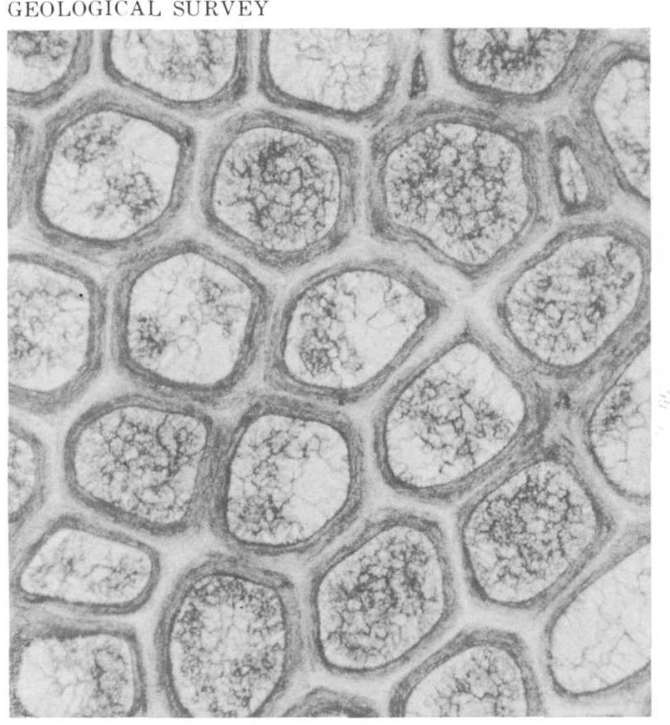

$1 \mathrm{a}$

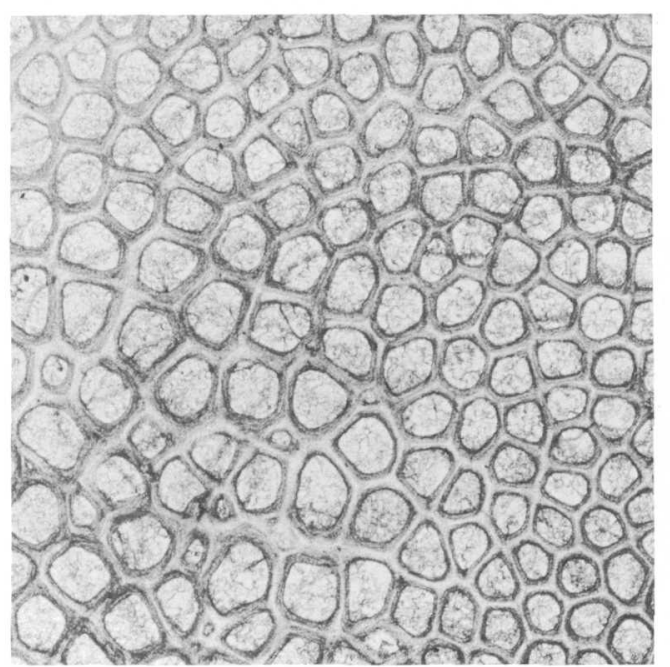

$3 a$

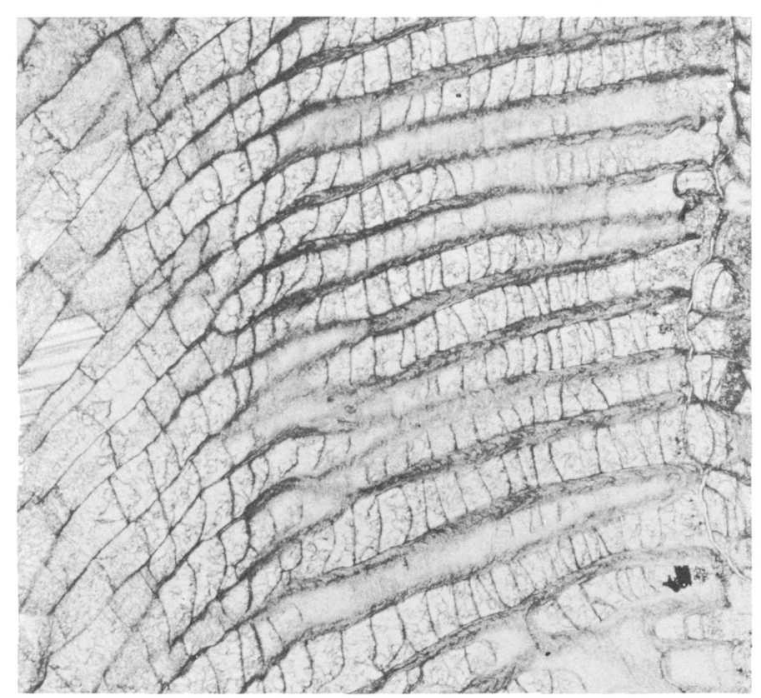

$3 b$

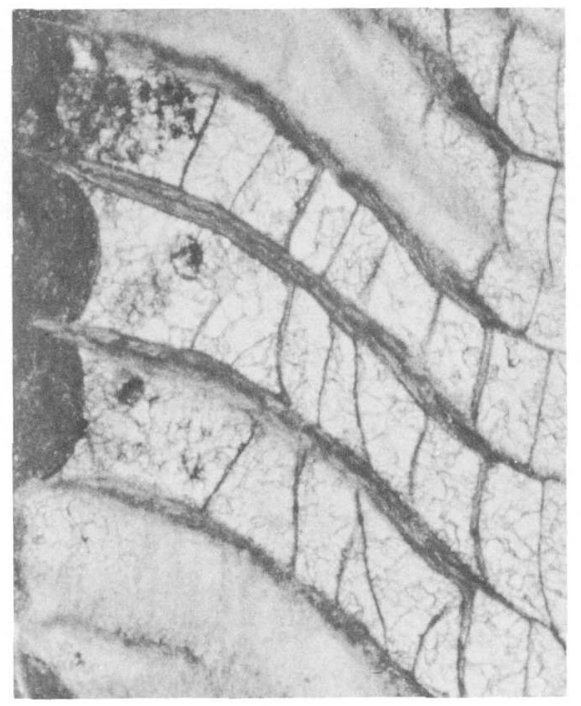

$1 b$

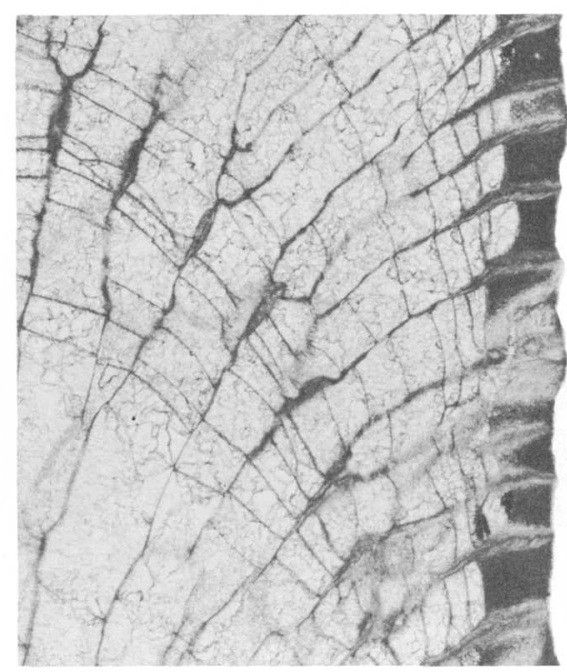

4

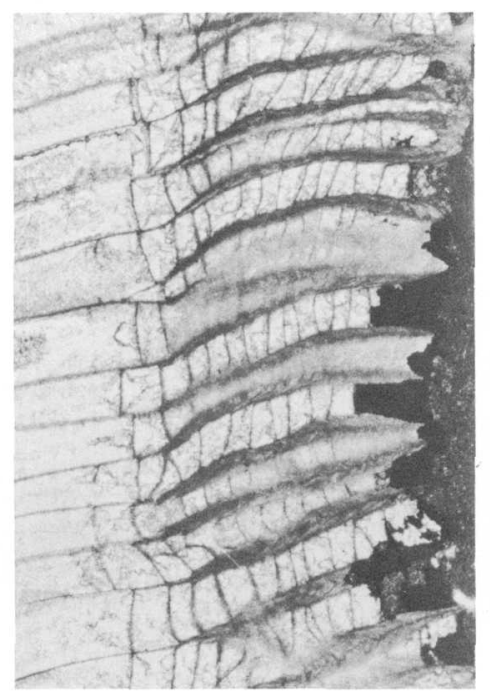

5

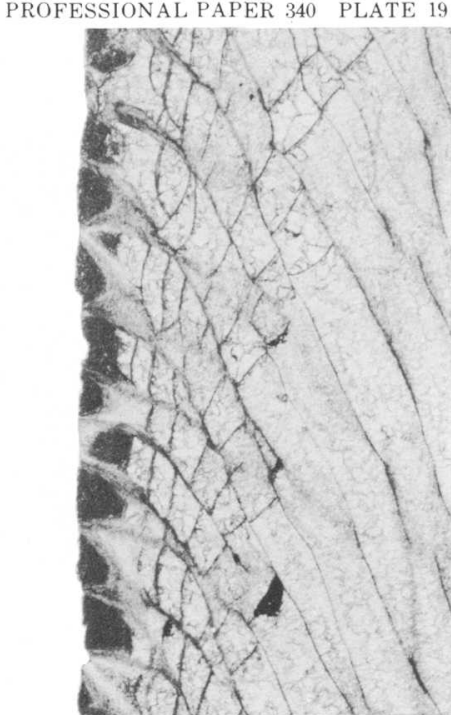

$2 a$

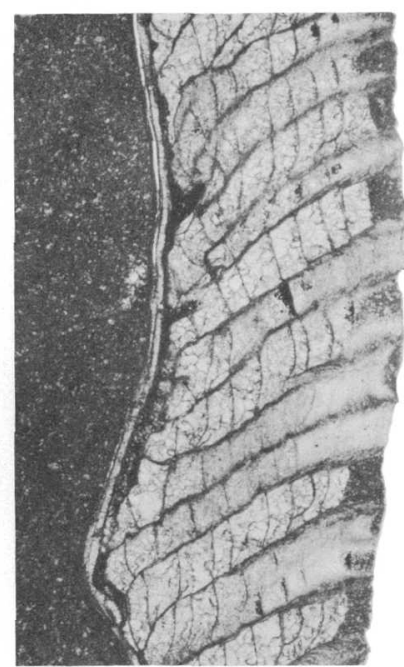

$2 b$

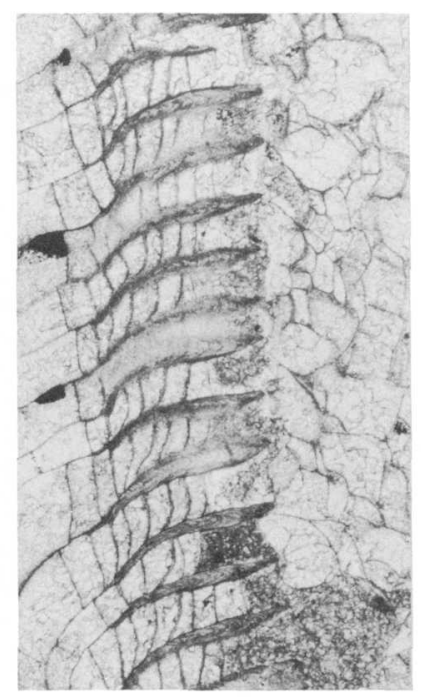

6

ATACTOTOECHUS FRUTICOSUS 
GEOLOGICAL SURVEY
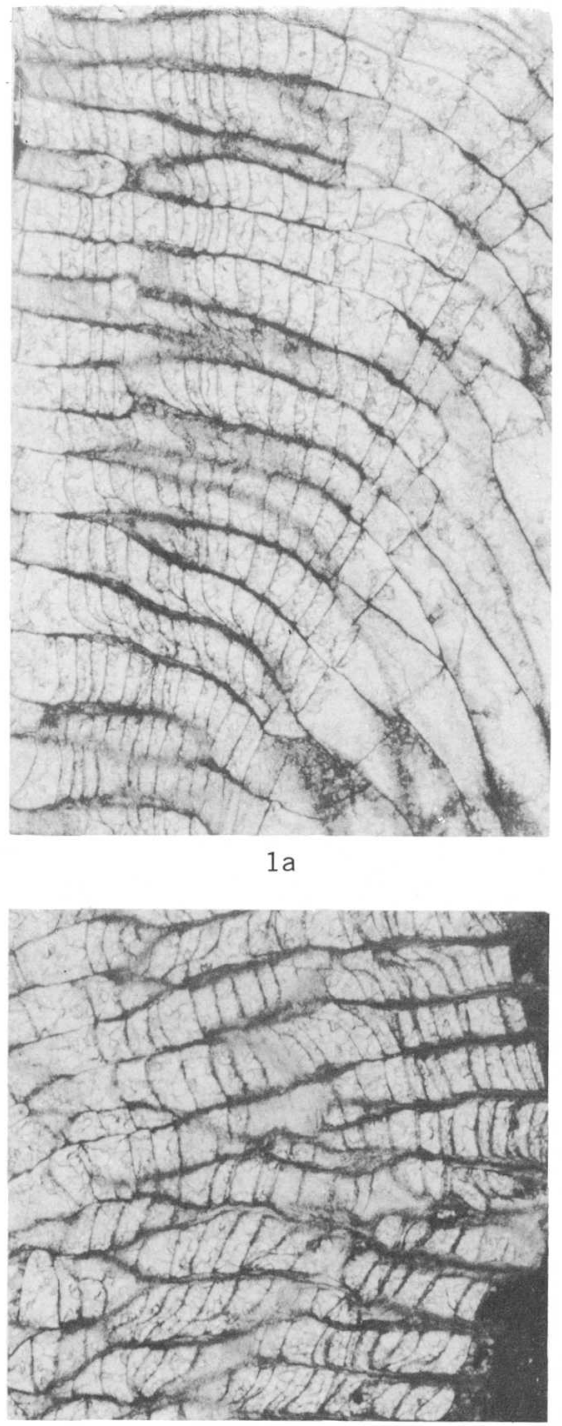

$2 \mathrm{~b}$

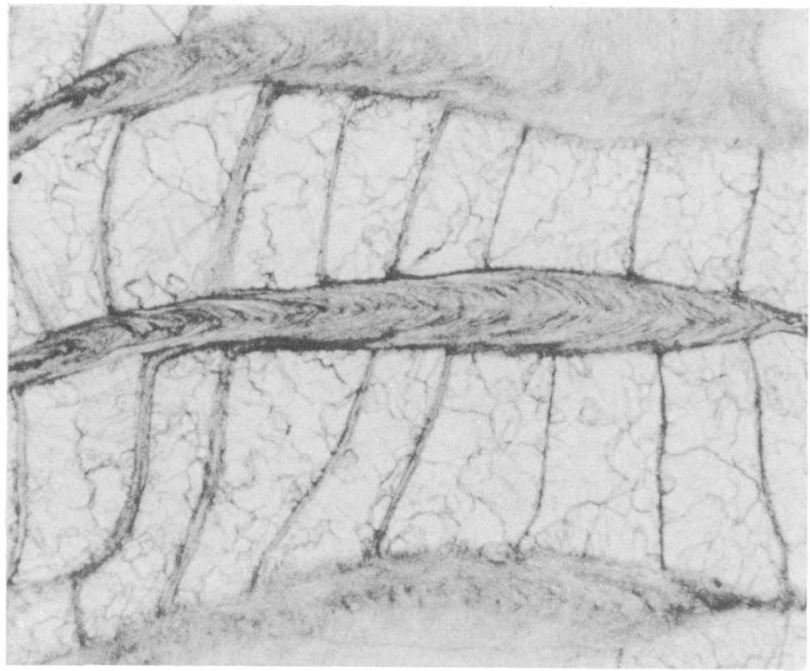

3

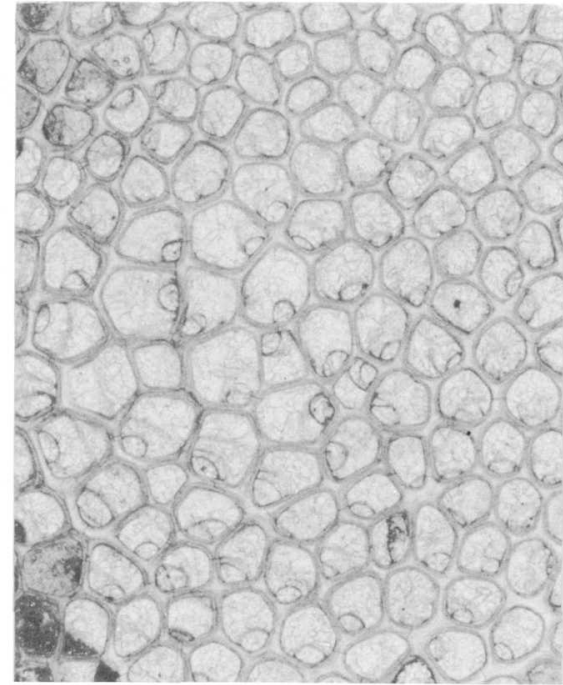

$1 b$

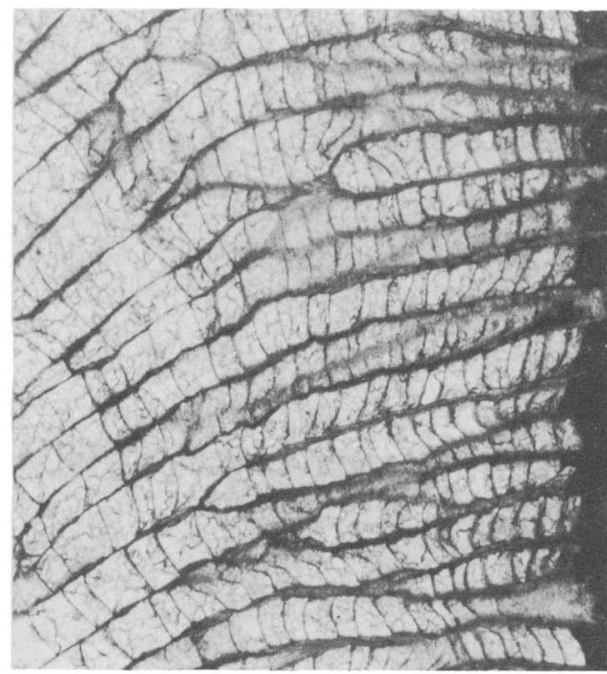

$2 \mathrm{c}$

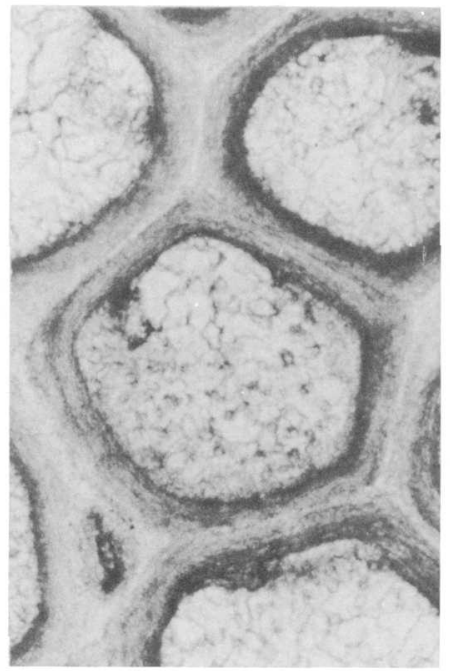

$4 a$
PROFESSIONAL PAPER 340 PI ATE 20

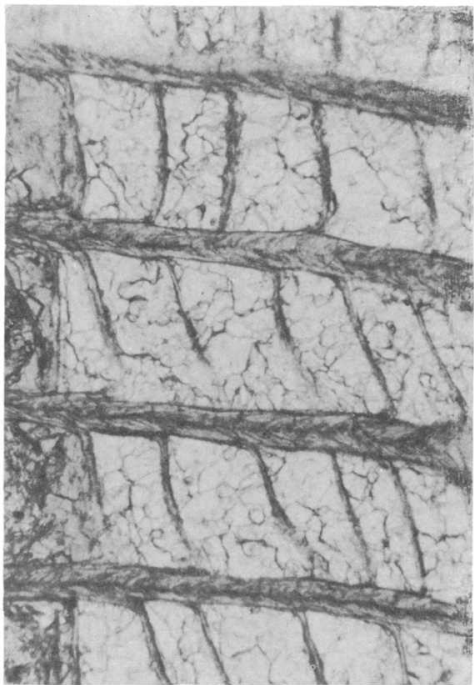

$2 a$

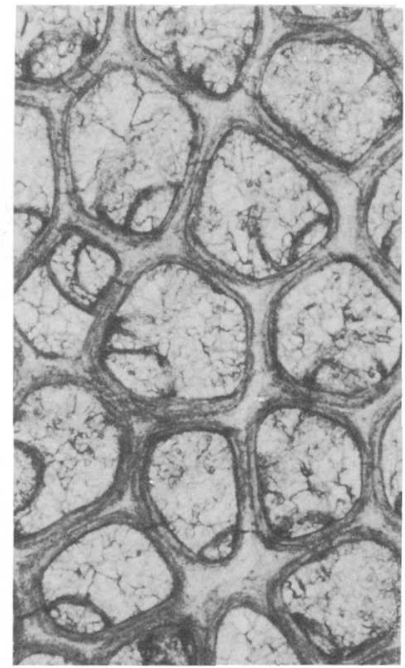

$1 c$

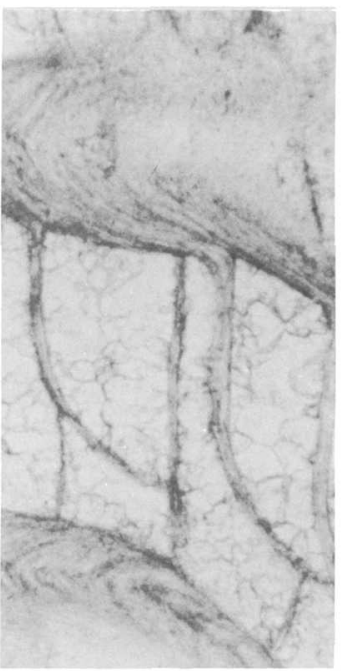

$4 b$

ATACTOTOECHUS HYSTRICOSUS, N. SP., AND ATACTOTOECHUS FRUTICOSUS 
PLATE 20

Figures 1, 2. Atactoloechus hystricosus Boardman, n. sp. (p. 75).

1a. Longitudinal section of holotype, USNM $133945, \times 20$. Note repeated cystoidal diaphragms in parallel series, also alternation of thick and thin-walled growth in the ephebic zone. Windom member of Moscow shale, collection 3570 .

1b. Tangential section of holotype, $\times 20$, showing a monticule with greatly enlarged megazooecia.

1c. Tangential section of holotype, $\times 50$, showing the narrowly amalgamate wall structure and the lack of acanthopores.

2a. Longitudinal section of paratype, USNM 133946, $\times 75$, showing atactotoechid wall structure with distinct zooecial boundaries. Note the minute spines on the distal (left) sides of the diaphragms. Windom member, collection 3570 .

2b. Longitudinal section of same zoarium, $\times 20$, cut through a monticule that displays megazooecia containing both strongly curved cystoidal diaphragms and planar parallel diaphragms.

2c. Longitudinal section of same zoarium, $\times 20$, showing the irregular undulations that are characteristic of the zooecial walls in the ephebic zone.

3, 4. Atactotoechus fruticosus (Hall) (p. 76).

3. Longitudinal section of identified specimen, USNM 133944, $\times 100$, showing atactotoechid wall structure with a distinct abutting of laminae at the zooecial boundary limited to the early ephebic region. Windom member, collection 3579.

4a. Tangential section of identified specimen, USNM $133947, \times 100$, showing integrate wall structure and minute spines of the diaphragms appearing as small circles in the zooecial void. Windom member, collection 3559.

4b. Longitudinal section of same specimen, $\times 100$, showing the minute spines on the distal side of the cystoidal diaphragm. 


\section{PLATE 21}

Figures 1-4. Loxophragma lechrium Boardman, n. sp. (p. 80).

1. Longitudinal section of paratype, USNM $133948, \times 50$, displaying atactotoechid wall structure and diaphragms typical of the species. Note the similar positions of the thicker diaphragms in each of the zooecia pictured, as if each zooid reacted in the same manner to changing environmental conditions. Wanakah shale member (as used by Buehler and Tesmer, in press) of Ludlowville shale, collection 3516.

2. Longitudinal section of paratype, USNM $133949, \times 50$, displaying many compound and cystoidal diaphragms. Note the sharp definition of the zooecial boundary by the intersection of laminae. Wanakah shale member, collection 3558a.

3. Longitudinal section of paratype, USNM $133950, \times 50$, showing a variant with abnormally thick diaphragms, most of them compound. Wanakah shale member, collection 3558a.

4. Longitudinal section of paratype, USNM $133951, \times 50$, showing a variant with parallel and evenly spaced diaphragms. Note rounded spine or node on distal side of diaphragm. Wanakah shale member, collection, 3502. 5-8. Loxophragma leptum, Boardman, n. sp. (p. 79).

5a. Tangential section of holotype, USNM 133952, $\times 20$, showing integrate wall structure, few acanthopores and mesopores. Centerfield limestone member of Ludlowville shale, collection 3561.

5 b. Longitudinal section of holotype, $\times 20$, showing the narrow neanic zone resulting in low axial ratios.

6a. Longitudinal section from paratype, USNM $133953, \times 50$, variant showing atactotoechid wall structure with poorly defined zooecial boundaries. Centerfield limestone member, collection 275A.

6b. Tangential section from same paratype, $\times 50$, showing small but numerous acanthopores and wall structure that has the integrate structure with a light, sharply defined zooecial boundary, but also might be considered amalgamate as there is a discernable nonlaminated zone between the zooecial boundary and the inner darker laminated zone.

7. Loingitudinal section of paratype, USNM $133954, \times 50$, showing typical atactotoechid wall structure and compound and cystoidal diaphragms typical of the genus. Centerfield limestone member, collection $275 \mathrm{~A}$.

8. Longitudinal section of paratype, USNM 133955, $\times 50$, showing thin cystoidal diaphragms and atactotoechid wall structure. Centerfield limestone member, collection 3561 . 
GEOLOGICAL SURVEY

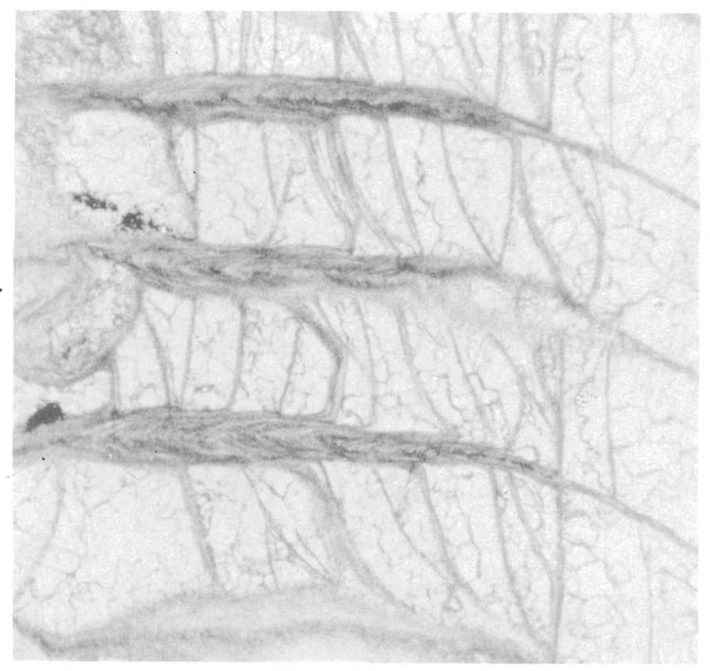

1

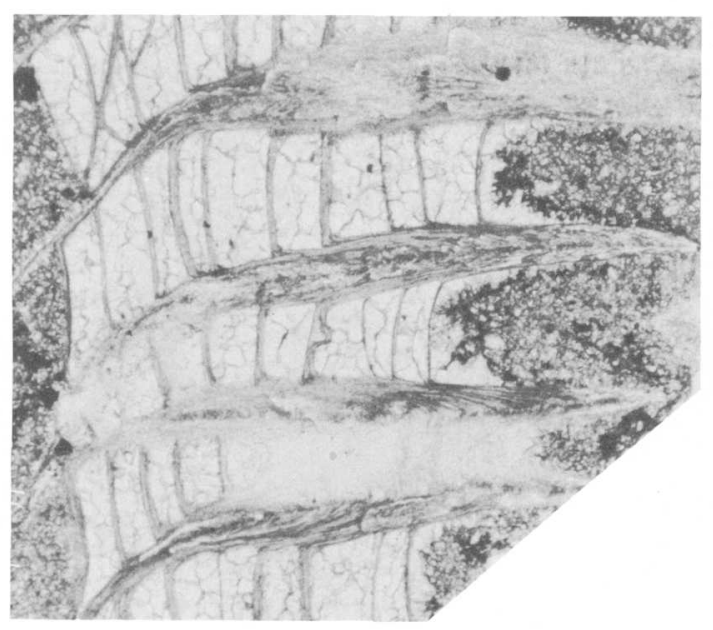

4

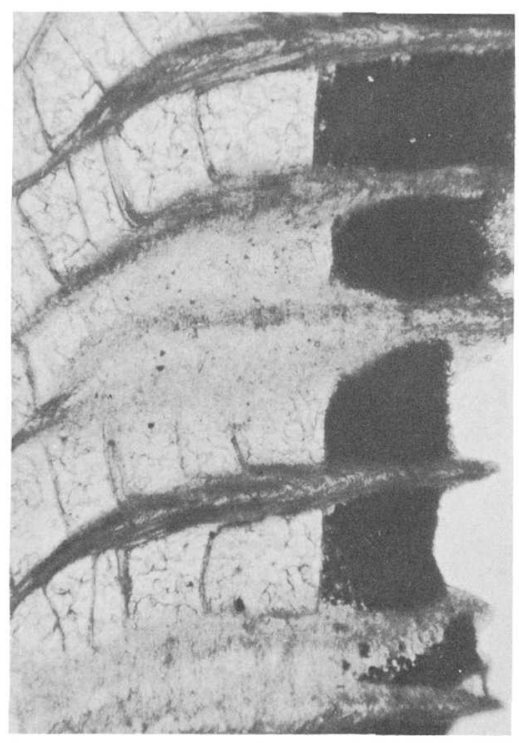

$6 a$

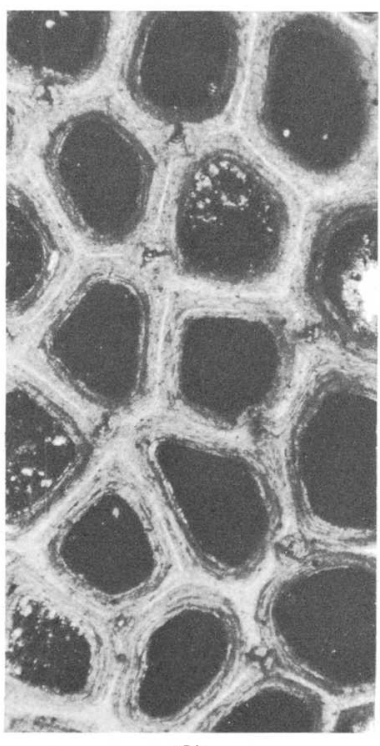

$6 \mathrm{~b}$

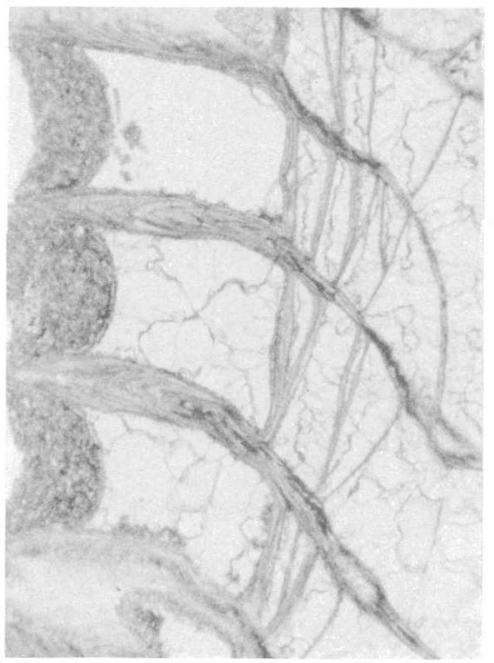

2

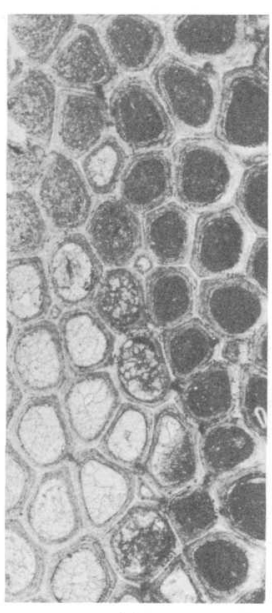

$5 a$

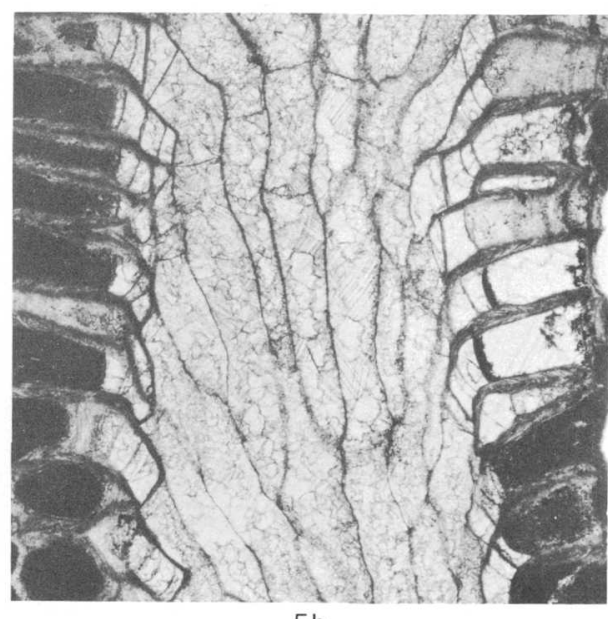

$5 \mathrm{~b}$

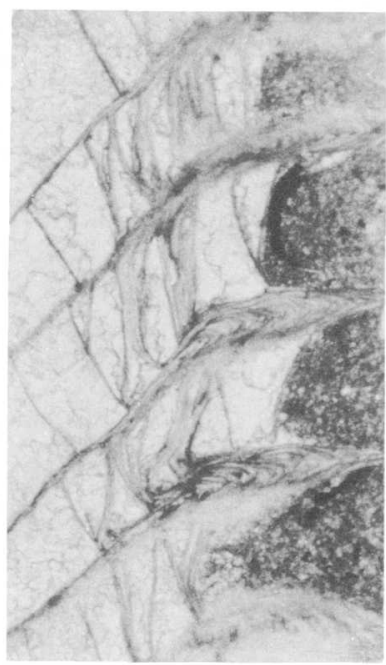

3

LOXOPHRAGMA LECHRIUM, N. SP., AND LOXOPHRAGMA LEPTUM, N. SP. 
GEOLOGICAL SURVEY
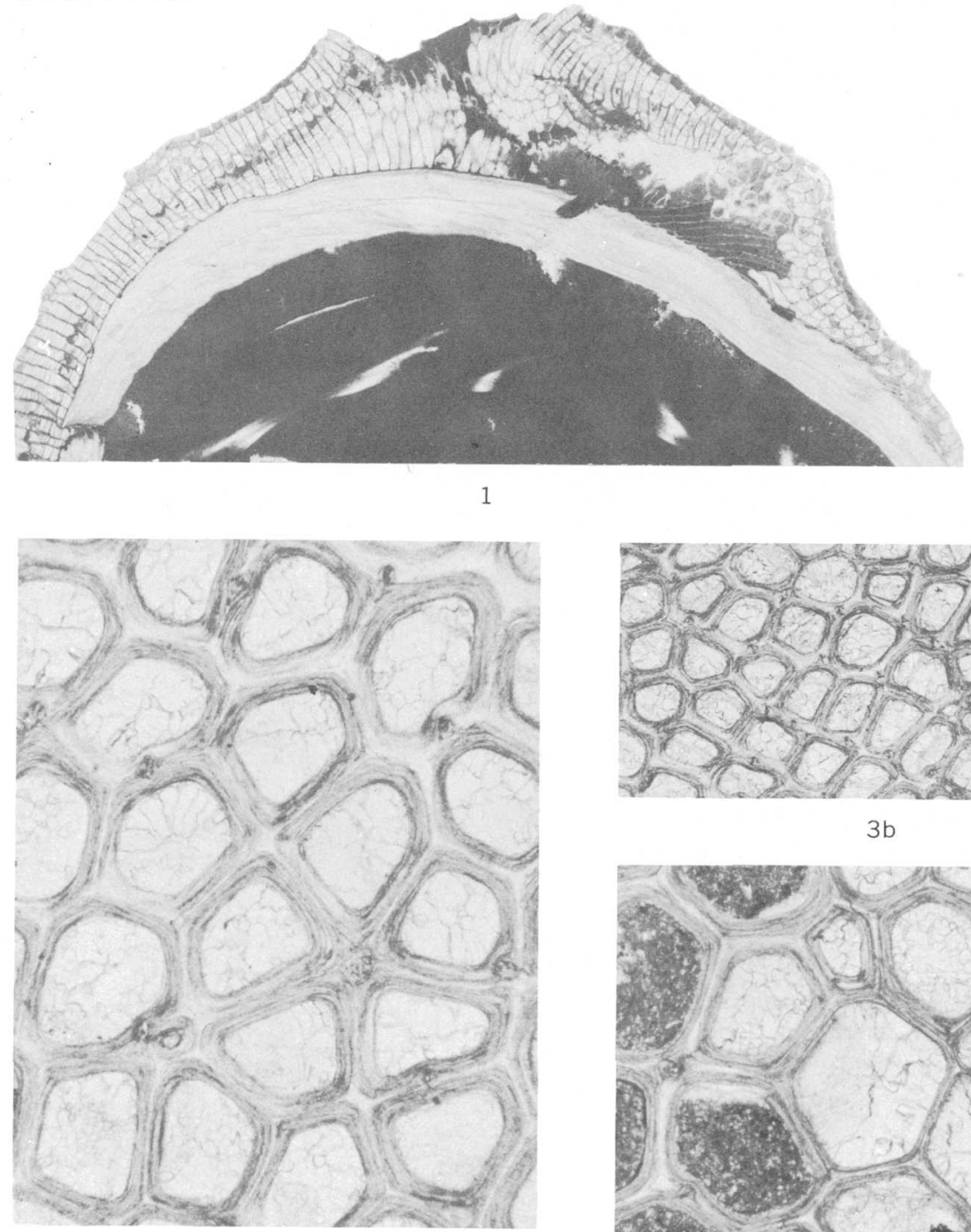

$3 a$

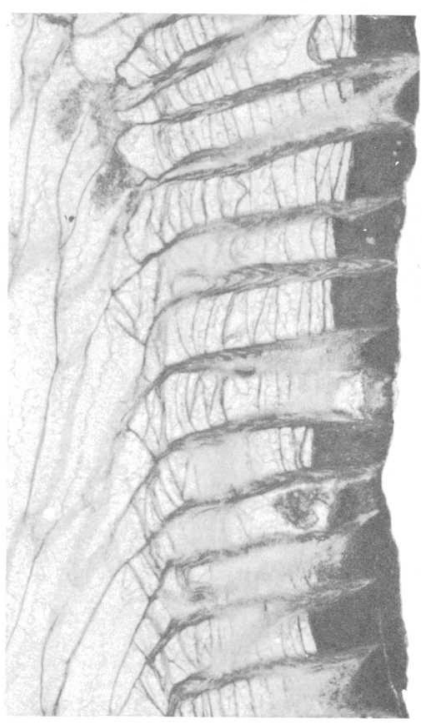

$3 c$

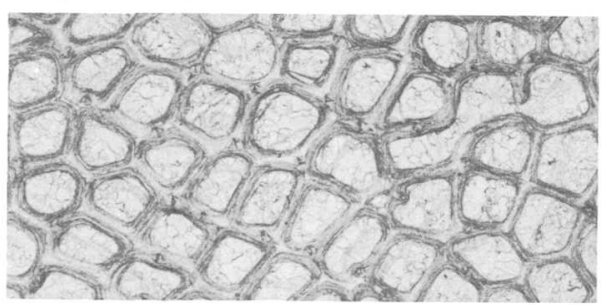

$3 b$
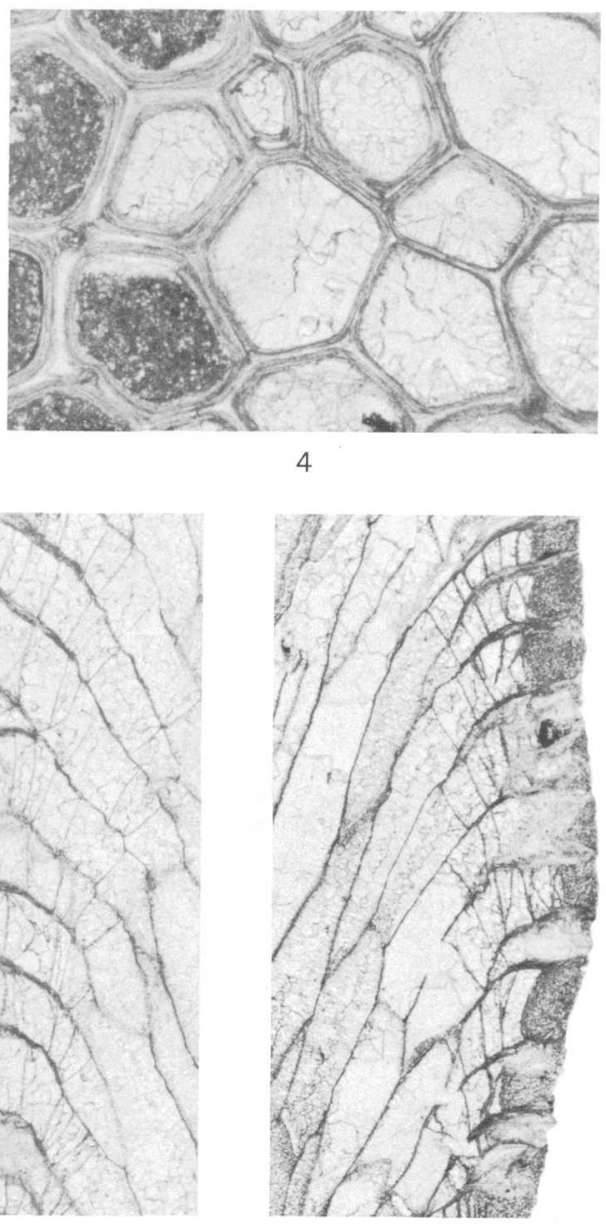

$3 d$
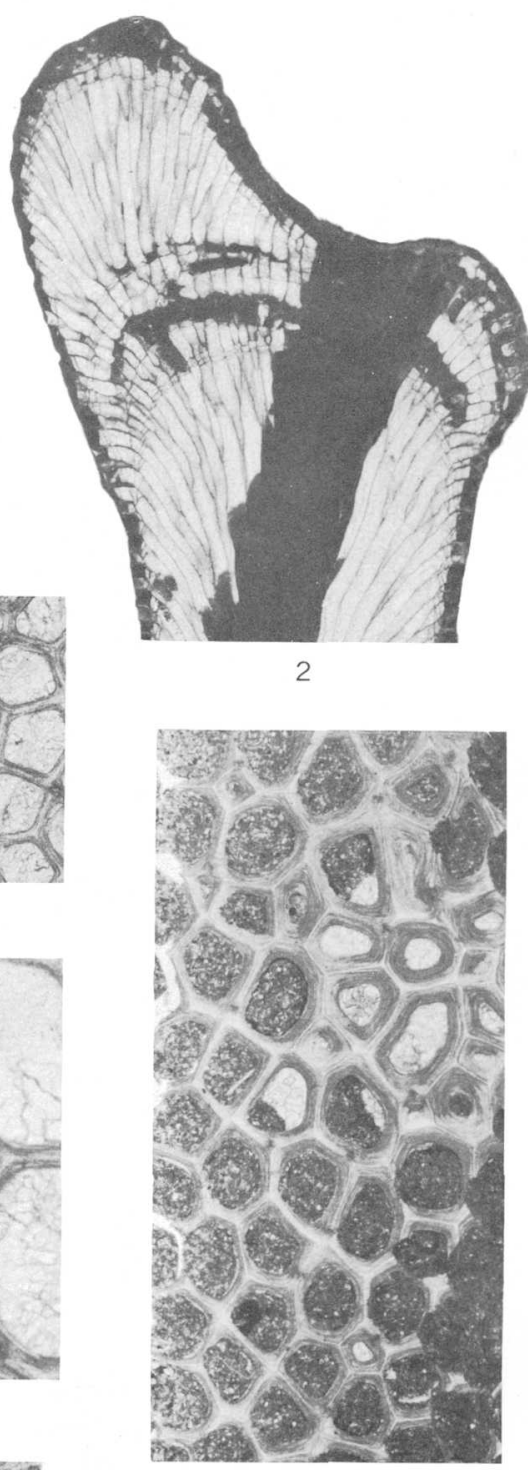

5

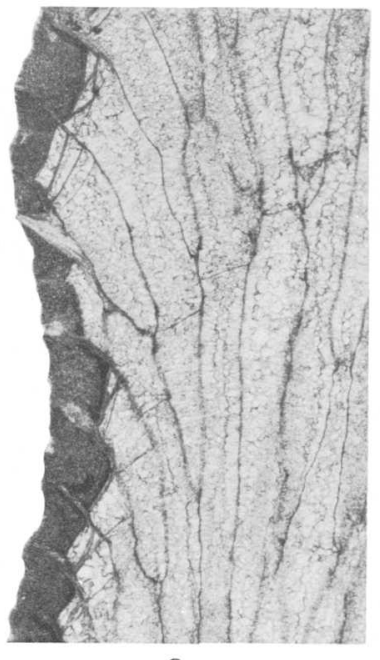

LOXOPHRAGMA LECHRIUM, N. SP. 


\section{PLATE 22}

Ficiures 1-6. Loxophragma lechrium Boardman, n. sp. (p. 80).

1. Longitudinal section of paratype, USNM 133956, $\times 4$, illustrating an incrusting zoarium giving rise to a branch at top center. Centerfield limestone member of Ludlowville shale collection $250 \mathrm{~B}$.

2. Longitudinal section of paratype, USNM $133957, \times 5$, showing a growing tip with $3-4$ diaphragms in the ephebic zone and two abandoned growing tips with fewer diaphragms remaining. Wanakah shale member (as used by Buehler and Tesmer, in press) of Ludlowville shale, collection 3515 .

3a. Tangential section of holotype, USNM $133958, \times 50$, displaying generally integrate wall structure and small acanthopores that cause some inflection of zooecial walls. Wanakah shale member, collection 3518 .

3 b. Tangential section of holotype, $\times 20$, showing rare occurrence of zooecia with incomplete walls. Wall laminae parallel the rounded projection of the incomplete wall indicating incomplete growth rather than a break.

$3 \mathrm{c}$. Longitudinal section of holotype, $\times 20$, showing a growth stage of 15-18 diaphragms.

3 d. Longitudinal section of holotype, $\times 20$, showing a growth stage of $7-9$ diaphragms.

3e. Longitudinal section of holotype, $\times 20$, showing a growth stage of 4 diaphragms.

4. Tangential section of paratype, USNM 133959, $\times 50$, illustrating magazooecia of a monticule. The thinness of the megazooecial walls is caused by the plane of the tangential section passing through the very early ephebic zone in the megazooecia of the distally projecting monticule, and a later, thicker walled ephebic zone in the zooecia surrounding the monticule. See profile view of monticule in figure 6. Wanakah shale member collection $3558 \mathrm{a}$.

5. Tangential section of paratype, USNM $133960, \times 20$, showing a monticule in which the megazooecia display their maximum wall thickness. King Ferry shale member (of Cooper, 1930) of Ludlowville shale, collection 3564.

6. Longitudinal section of paratype, USNM $133961, \times 20$, showing a growth stage of 10-11 diaphragms and a high monticule accentuated by an overgrowth. Kashong member (of Cooper, 1930) of Moscow shale, collection 3558. 